AROUND fhe CARIBBEAN
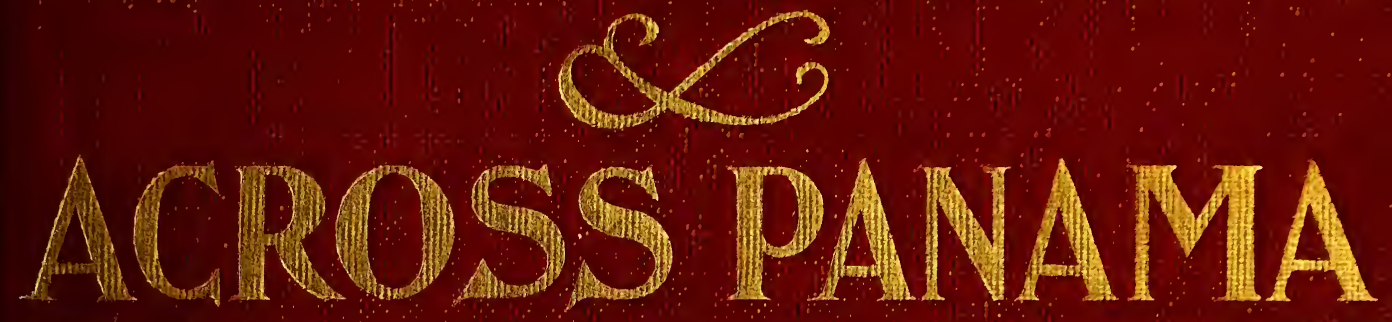

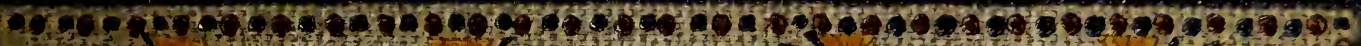

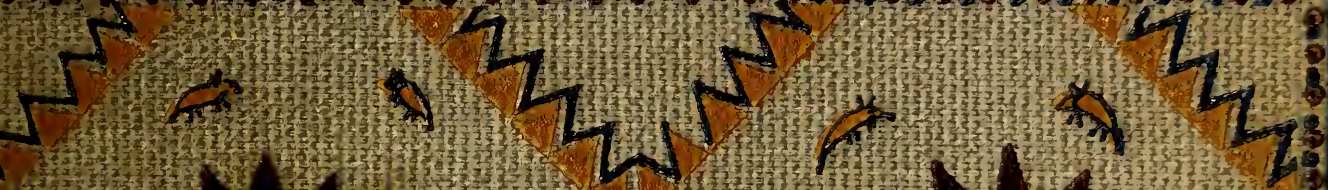

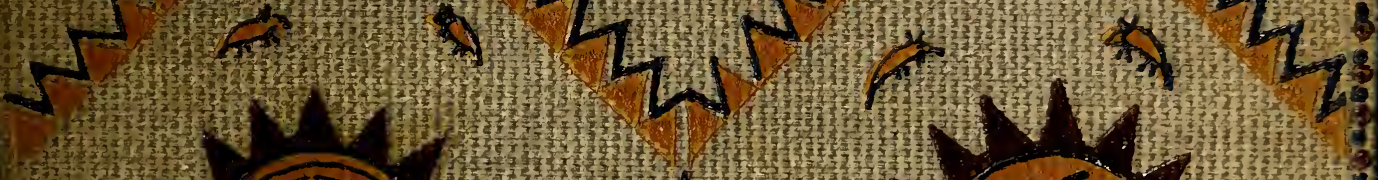
1. $40.10:(-1): 5$

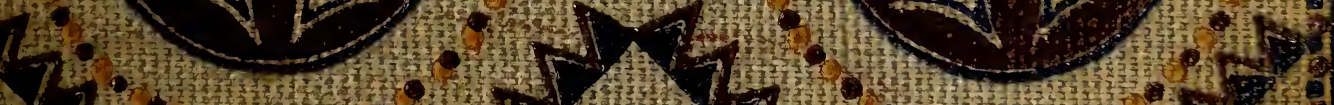

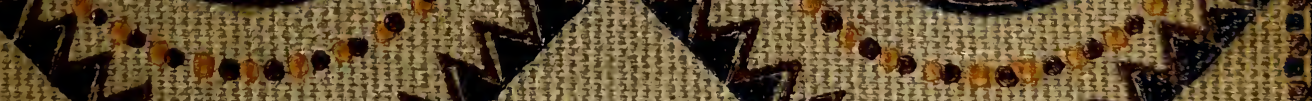
- 


\section{Smithsonian Institution Sibraries}

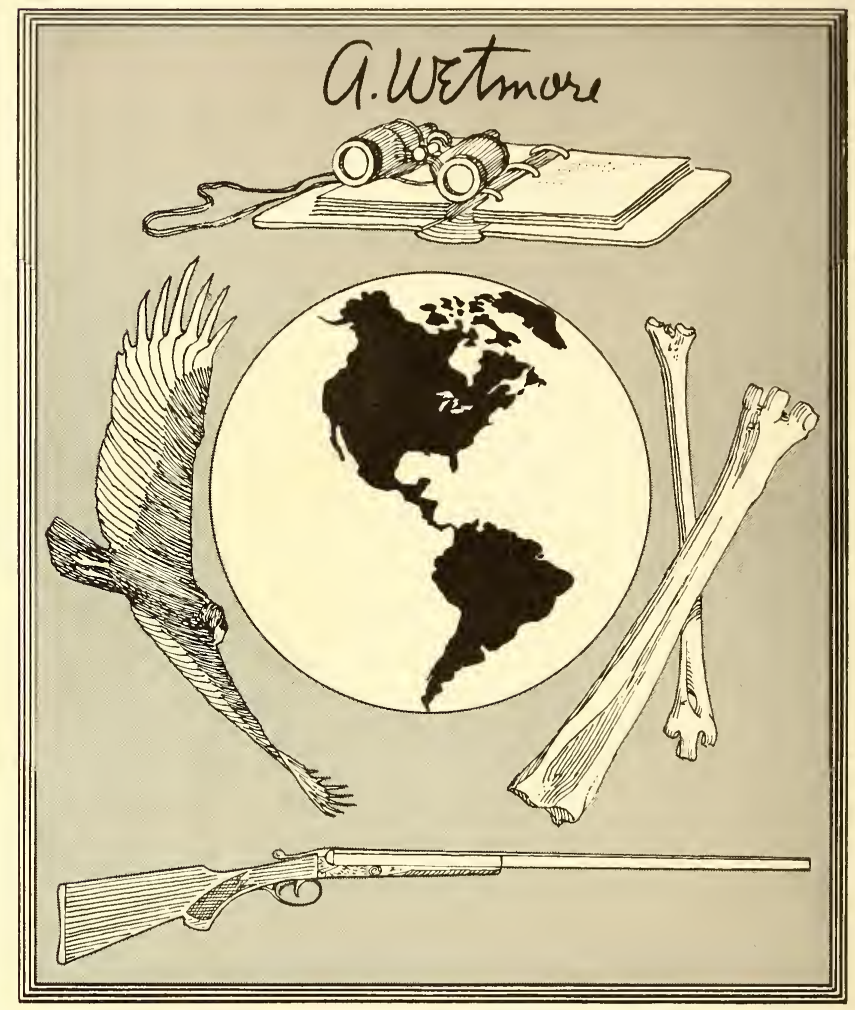

Alexander Wetmore 1946 SixthSecretary 1953

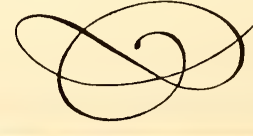


a. ustmose 



\section{AROUND THE CARIBBEAN \\ AND}

ACROSS PANAMA 



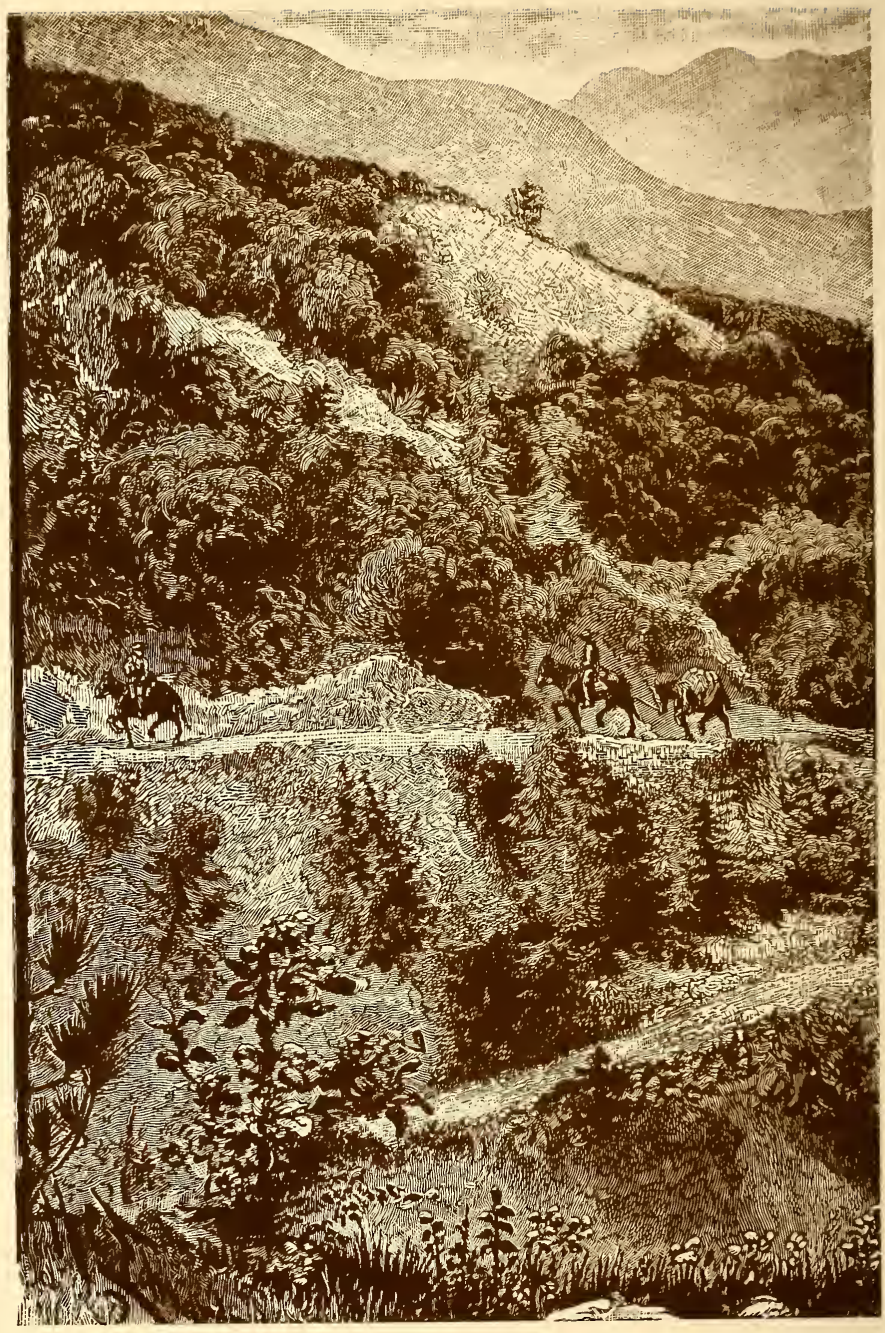




\section{Around the Caribbean and}

Across Panama
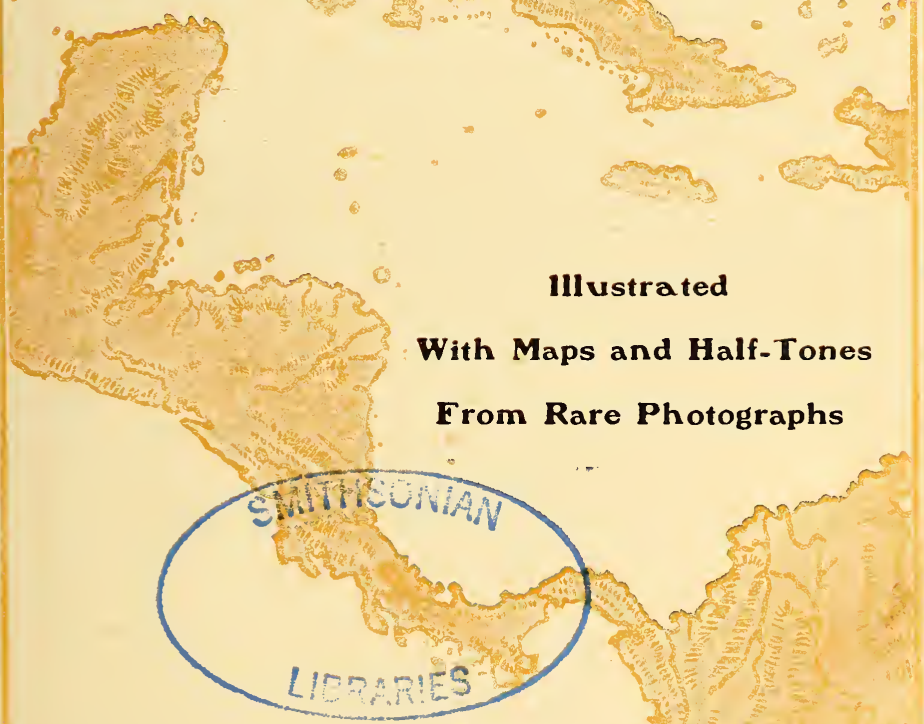

Boston \& New York

H. M. Caldwell Company

Publishers 
Copvright, 1903,

By H. M. Caldwell Company

Colonial 非ress

Electrotyped and Printed by C. H. Simonds \& Co.

Boston, Mass., U. S. A. 


\section{PUBLISHER'S NOTE}

Acknowledgments of gratitude are due to Dr. Arturo de Brigard, Consul General of Colombia, for valuable plates and illustrations; and to W. R. Gillespie, Esq., of the AmericanHonduras Company, for photographs of the Rio Patuca and it's savannahs; and to Dr. Juan J. Ulloa, Consul General of Costa Rica, for interesting photographs. 



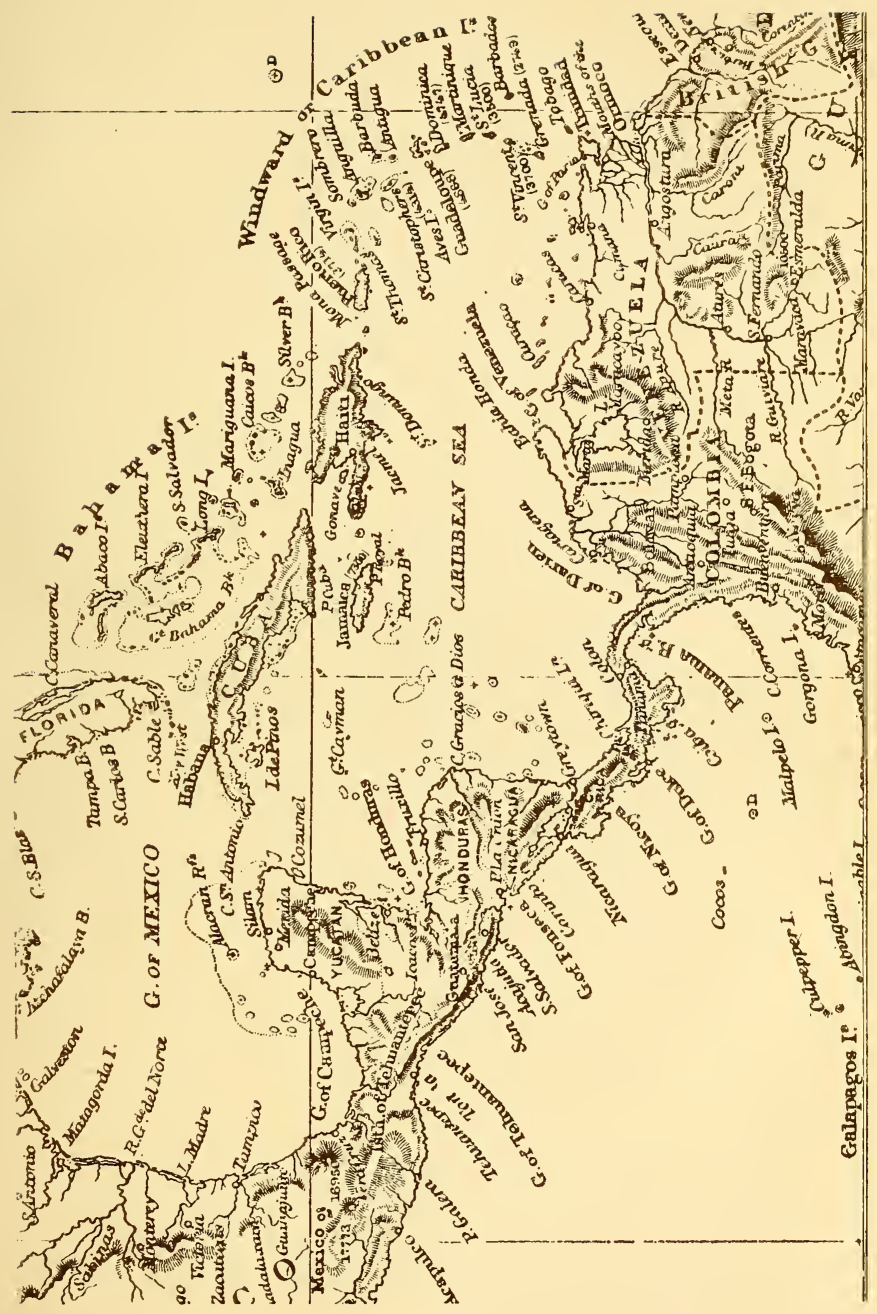





\section{PREFACE}

OF all the regions adjacent to the United States none are so attractive or present such varied conditions of development, scenic beauty, and commercial opportunity as the countries about the Caribbean Sea. From the islands of the West Indies, with their teeming population, some of them the most densely peopled spots in the world, to the low lands of Central America, where, in the solitude of the wilderness, a human voice is all but unknown, we find a varied country. It is a vast region surrounding the pleasant waters of the Caribbean Sea, inhabited by divers people, and presenting for our consideration snow-capped mountains, temperate uplands, broad savannahs and grassy plains, open valleys, dense jungles, and mighty rivers pouring their torrents of muddy water into the sea. One meets Spaniards, Englishmen, Negroes, and Indians of many different tribes. Of products everything known to the American tropics is 


\section{P R E F A C E}

to be had. Commerce is flourishing as yet only in its infancy, but with the opening of work on the Isthmian Canal a great impetus will be given to all this region; and many will turn to the South, some looking for business in the cities, others going to the wilderness on projects of development, or seeking to gather products.

For my part, I have visited almost every point of the Caribbean regions, and expect to go there again many times. What has happened to me, is similar to what others may expect; descriptions of a country are all very well, but incidents and adventures of the road give a much clearer idea of the conditions and of the circumstances which one must expect to encounter. 


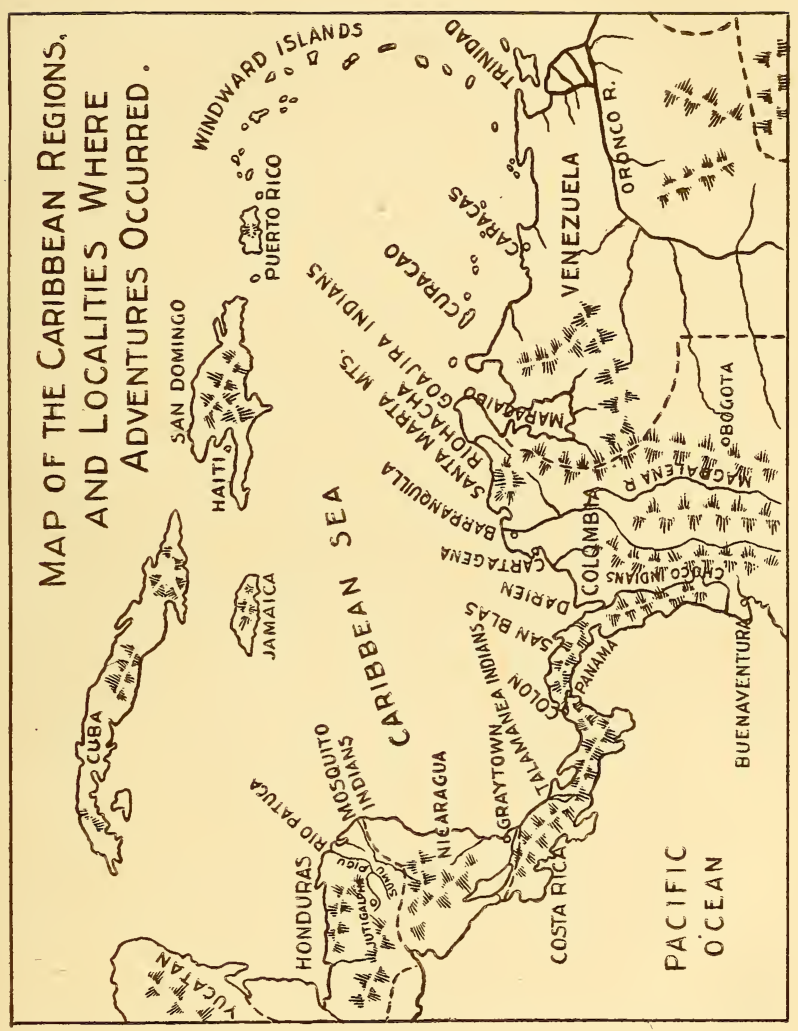





\section{CONTENTS}

CHAPTER PAGE

I. GoIng South • . $\quad$. $\quad$. 1

II. Camping on the Coast of Spanish HonDURAS . . . . . . . 4

III. Indians AND Mosquitoes $\quad$ • $\quad$ • 17

IV. Wild Animals and a Panther at Night 30

V. Alone in an Indian Village . . 37

VI. A Startling Proposition and a Heavy

FLOOD . . . . . . 45

VII. A Row IN CAMP . . . . $\quad$ - 51

VIII. Alone with the Indians Again • . 56

IX. Over the Mountains with Indian

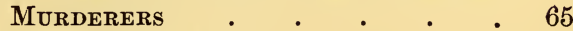

X. Treachery and Poison • • • . 79

XI. Perplexities and Spanish-American Hospitality $\quad$ • $\quad$ • $\quad$ •

XII. Examining a Mine under Difficulties 107

XIII. Over the Mountains on a Race against

Time . . . . . : . 120

XIV. A Rough Journey to the Coast . . 130

XV. Honduras to Costa Rica via New

Orleans . . . . . . 138

XVI. The Death Dance of the Talamanca

INDIANS . . . . . . . 144

XVII. Up the Atrato River in Colombia . 175

XVIII. The Wilderness of the Choco Country 185 


\section{O N T E N T S}

CHAPTER

XiX. A Canoe Route from the Caribbean

to the Pacific . . . . 197

XX. Across Panama . . . • . 215

XXI. The Indians and Resources of Panama 226

XXII. Panama and Nicaragua Routes for the

Isthmian Canal $\quad . \quad$. $\quad 235$

XXIII. Hunting for Gold in Antioquia . . 242

XXIV. A Canoe Voyage in the Open Sea - 251

XXV. The Sierra Nevada de Santa Marta

Mountains . . . . . 258

XXVI. Among the Goajira Indians . • . 294

XXVII. Ramon, a Story of the Goajiras . 307

XXVIII. Across Country to Bogota . • . 336

XXIX. Throdgh the West Indies . . . 351

XXX. A Faithaul Guide . . . . . 371 


\section{LIST OF ILLUSTRATIONS}

Pine lands and savannahs near the Rio Patuca, on the

PAGE way to the Indian village (See page 38) Frontispiece Map of the Caribbean regions

Map of the Caribbean regions and localities where adventures occurred . . . . . . . vii

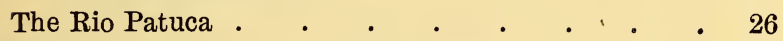

A river of the tropical low lands $\quad$. $\quad . \quad$. $\quad . \quad 52$

Mosquito bars prepared for the night near a tropical river . . . . . . . . . 70

Jungles in the low lands of Central America . . 134

Entrance to the king's house. "A shed protected the entrance from the rains, and formed an open veranda where horses were tied, and the Indians gathered at times" . . . . . . 146

Josecito. Heir to the kingship among the Talamanca Indians . $\quad . \quad . \quad . \quad . \quad . \quad . \quad .150$

Josecito $\quad . \quad \cdot \quad \cdot \quad \cdot \quad \cdot \quad \cdot \quad \cdot \quad \cdot 156$

The private house of Antonio, King of the Talamancas 160

Talamanca Indians. Men who are almost wild creatures of the woods. The Indian on-the left is the man who prepared the models of the dead as if for burial . . . . . . . . .

Model of a dead Talamancan Indian prepared for laying out in the woods. A tambour back of the model, and above it articles of adornment used at the dance for the dead . . . . . . 


\section{LIST OF ILLUSTRATIONS}

Cartagena, Colombia. View outside the city wall . 178

Natives catching fish. Men who tell of the quicharo and other strange objects believed to inhabit their rivers . . . . . . . . .

Map illustrating the canoe route from the Caribbean to the Pacific

Cartagena, Colombia. View across the harbour, where the principal trading centre will be located when the canoe route from the Caribbean to the Pacific is developed . . . . . . . . 212

Low tide in the Pacific off Panama . . . . 216

A Spanish-American country town. Through the American tropics there is great similarity among the towns and villages, and all look very much alike . . . . . . . . 220

Atlantic entrance to the Panama Canal . . . 224

Maps of Nicaragua and Panama Canal routes drawn on exactly the same scale . . . . . . 236

Crater of Poas, one of the volcanoes of Costa Rica, among the mountains south of the Nicaragua Canal route . . . . . . . . .

Crater of Irazu. A silent volcano of Costa Rica overlooking the Nicaragua Canal route . . . 240

City of Barranquilla, Colombia. One of the most rapidly developing places in South America . 242

Market-place in Madellen, Colombia . . . 246

Street in Dibulla, a little town at the back of the Sierra Nevada de Santa Marta mountains in Colombia.

Portrait of an Aurohuaco Indian. The people who deserted their city when our party proposed to visit them . . . . . . . . .

An Aurohuaco Indian, one of the men who might have rolled great rocks down on us from the mountains had we remained in their country . . . 


\section{LIST OF ILLUSTRATIONS}

A Goajira Indian woman of high position among her people . . . . . . . . . . 296

Collection of articles used by the Goajira Indians exhibited at the American Museum of Natural History, New York . $\quad . \quad$. . . .

Goajira Indians. A marriageable girl offered by her uncles . . . . . . . . .

Belts used by the Goajira Indians. Their principal clothing during war and hunting expeditions . 314

Goajira Indians prepared for hunting or war . $\quad 318$

Tumas. Beautiful red beads found in ancient graves among the Sierra Nevada de Santa Marta mountains, used by the Goajira Indians and considered priceless. The bullet-shaped specimens at base of picture are similar to the bead given to Ramon . 332

The road over the Andes to Bogota, Colombia . . 342

Scene in a Spanish-American city of the uplands. Bolivar Square, Bogota, Colombia . . 346

Steamboat on the Magdalena River . . . . 350

A house in the interior of Jamaica. Occupied by one of the independent land-owning negroes of that island . . . . . . . . . 358

The wild mountains of the interior of Jamaica, British West Indies . . . . . . . . 364

In tropical America the poor labour under heavy burdens . . . . . . . 372 



\title{
AROUND THE CARIBBEAN AND ACROSS PANAMA
}

\section{CHAPTER I.}

\author{
GOING SOUTH
}

ONe cannot explore the Caribbean regions in a month or even in a year, and it is some time ago that I found myself with a considerable undertaking in view, the exploration of all that country for the South American Land \& Exploration Co., Ltd.

Plans had been carefully considered, and I was to go alone, use my own judgment as to finding companions on the way, and explore the gold regions, the timber lands, the rubber forests, and other resources of the tropics. I crossed 


\section{AROUND THE CARIB BEAN}

and recrossed the Caribbean Sea many times, but for convenience in relating all that happened I will crowd the incidents of a long period into a tale as of one continuous journey.

Going south is very easy. Comfortable steamers leave New York at regular intervals; the traveller at ease on his way watches the waters of the ocean change day by day to the deep blue of the tropical seas, feels the air grow warmer as the breezes come up from the south; a glimpse of green islands in the distance, beyond them the sweeping trade-winds and turbulent blue waters of the Caribbean; then a line of mountains, gray in the distance, and in a little time the steamer anchors near the shore. A strange odour of swamps and forests fills the air, a damp clinging heat settles oppressively about one. Presently a crew of natives comes aboard, some in rough cotton clothes, one or two in gaudy, ill-fitting uniforms, and some dressed in a mixture of both, looking strangely incongruous and not very clean. Now one is to leave the steamer, and the expectant traveller goes ashore with the motley crew of natives, amused perhaps at noticing how they all shout out orders and direct one 


\section{AND ACROSS PANAMA}

another. When the boat reaches land, one may find a rough wharf, but at most places only a lot of sheds marks the landing, where there is a stretch of white sand burning hot under the sun of the tropics, a few straggling bushes, some cocoanut-trees, - ragged specimens tossing to and fro in the wind, or drooping listlessly if the day is still, - patches of coarse grass, a vault of blue overhead where surely a group of buzzards will be circling about, and everywhere intense burning heat. One hurries to the nearest protecting shade, and is glad when permission is received from the custom-house authorities to leave the landing-place and seek the interior of one of the low, cool houses in the city beyond.

Under such conditions, I arrived at the little seaport of Truxillo, in Spanish Honduras. The details of the scene were not pleasing, but the broad expanse of the blue ocean, the intense sky, the great jungles stretching away below the city, and the lofty mountains toward the interior combined under the flood of glowing sunlight to form a scene of dreamy loveliness. 


\section{CHAPTER II.}

CAMPING ON THE COAST OF SPANISH HONDURAS

A Few days in Truxillo, and I started down the coast in a small sailboat with some adventurous Americans and a goodly company of negro passengers.

These daring Americans were taking me to see property and mines, in which they, with some of my friends in New York, were interested. Their time was passed in praising each other, drinking, telling me of the great things they had done, and in doing me for money. It was all part of a prearranged plan, and had to be tolerated.

As we stood along the coast I saw a succession of low, sandy beaches, a tangled growth of jungle beyond, and then a range of blue mountains in the distance.

After three days under a tropical sun, the 


\section{AND ACROSS PANAMA}

captain informed us that we had arrived off our destination, the inlet of Brewer's Lagoon, and that he would put about for the shore, reminding us that he did not guarantee a safe entrance, and in case of loss the damage was for our account.

Passengers were ordered below, but the captain allowed me to stay on deck, perhaps because I had taken the tiller for part of the time on the way down, and had gotten along fairly well sailing the boat.

"What will happen to us," I asked, "if the boat runs aground?"

"Do you see those big waves?" the captain replied, in the low, deep voice common to the negroes, but with the most perfect enunciation, and no sign of negro dialect. "There are the shifting sand-banks; the channel is never the same; it is always changing; if we ground, the boat will be beaten to pieces; our people will swim ashore, but the sharks will eat white men; you were not made for these countries. Don't talk to me now."

Surely a pleasant prospect. I had sailed many a small boat in rough water, and was not at all afraid of a swim; but the sharks, - 


\section{AROUND THE CARIB BEAN}

how awful it would be to feel their great jaws close on a leg, and then be torn to pieces by a company of them attracted by the blood!

"Are there really many sharks?" I asked, in a whisper.

"Yes; don't talk," answered the captain.

A big negro called Tom, a perfect specimen of health and strength, said to me: "See that swirl in the water over there, and see that thing moving just ahead of the boat. They are gathering all around us. Here dead animals float out to sea; that is why they come."

We were approaching the shore now. Great, muddy waves rose up with a threatening comb. rippled into a foaming line along the top, and then settled down again. I could see no sign of an inlet, but still the little boat kept on, the captain now giving orders in his native tongue, a remnant of African memories used all along the coast. The men stood at their places, and then, swinging the sail full to the wind, the captain stood directly for the shore. For a moment we ran quietly before the wind, then a great sigh seemed to rise up among the waves, and with a trembling and dragging the boat went grinding along the bottom. Behind us came a rolling 


\section{A N D ACROSS PANAMA}

wave, in which, as it rushed toward us, I pictured thousands of evilly disposed sharks; in another instant the boat went staggering on, then it came down on its side, and seemed to be endeavouring to bury itself in the sand; waves were now breaking all about us, and we were not more than fifty yards from the shore. Once more the boat rose up and staggered forward, came down with a bang, that sent us all on our backs; the next instant a wave dashed over us, and then, with a grinding and dragging, while the men shouted out to each other, the boat seemed to make a final effort and floated gently into quiet water behind the bar. Here a current was running out to sea like a mill-race, and it was some time before she could be brought around to the wind and started toward the inlet.

"We disappointed the sharks that time," the captain said, while the men began making vows that they would never come again with such a heavy cargo.

Then all the passengers began talking at once, but I felt little patience to hear them, and, going to the bow of the boat, sat on the guardrail beside Tom, who gave a kind of sympathetic rub up against me, a movement expres- 


\section{AROUND THE CARIBBEAN}

sive of satisfaction, such as a great dog gives at times, and then said, "You needn't look so white and frightened about it; we would have taken care of you, anyway."

A landing was made on the inner side of the sand point at Brewer's Lagoon. I scrambled over the side of the boat, and immediately a painful, smarting sting developed on my face and hands, caused by the sand-flies, tiny enemies, too numerous to combat; and soon they converted our hopeful company into as quarrelsome a set of individuals as ever made themselves disagreeable to one another in a tropical country. The negro sailors did not mind the sand-flies very much, and they soon had the cargo on shore; then the boat prepared to go away. I wanted Tom to stay with me, but he would not hear of it, and urged that I should return with them, but that could not be. Tom had been a faithful servant, and I felt I should miss him sadly; for continued good nature, strong, steady muscles, and a faithful spirit are rarely found, especially in the tropics. As the boat sailed away, I was lonely and discouraged, and determined that when I returned 


\section{AND ACROSS PANAMA}

to Truxillo I would engage Tom for a long cruise; but I never saw him after.

A circumstance not a little to be regretted in a traveller's life, is the parting from faithful people. One meets with many who are companionable and worthy of esteem, - rough Indian guides, courageous and true; vigorous negroes, ready to dare anything in one's service; courteous officials, kind friends, and charming hostesses; and at parting one resolves he will meet them at some future time, but often they are never seen again.

On the sand point at Brewer's Lagoon our camp settled itself to await the pleasure of the Mosquito Indians who were to take us on our way. The days were not pleasant, but after I found that a mixture of kerosene oil, carbolic acid, and vaseline, if smeared thick enough on the hands and face, would keep the sand-flies from bothering, life became tolerable, and the evenings were always charming, for then the sand-flies went away, and the mosquitoes did not come till late.

When one has nothing but corned meat in tins, it is really noticeable with what eagerness one starts on the chase, and, when evening 
came, I was always ready to take my rifle and follow any guide who might be willing to lead the way. At our camp there was a negro called Big George, who stood six feet four, and knew all the country round about. Frequently, after sunset, he and I would go among the sand-dunes looking for deer. We never got anything. Big George said I talked too much, but I am not so sure about that.

One night we determined to follow the beach looking for turtles. It was a beautiful experience; under the intense moonlight the sand looked like a pathway of silver stretching out in the distance, with the ocean and the jungle, one on either hand, each shrouded with the mystery of night; from the ocean the sound of the waves breaking along the shore, and from the jungle the cries of wild animals - weird voices from creatures unseen. Strange surroundings, intensified by the presence of fierce semi-naked Indians, who, following one after the other, went like shadows stealing silently along the sand!

On and on we went, our hopes frequently raised, to be followed only by disappointment. Sometimes it was a log glistening in the moon- 


\section{A NDACROSS PANAMA}

light; again a patch of shells would so much resemble a turtle that out steps would quicken impulsively. Finally, Big George said it was of no use; the moon was too clear. But just then something unusually bright in the distance caught my attention, and hurrying on, we saw that this time a really large turtle was just before us, resting quietly on the sand. Now all was excitement. Nearer and nearer we crept. The turtle, all unsuspecting, remained quiet; then suddenly its head was raised for an instant only, and it started clumsily for the water. Immediately the Indians were upon it, and for a moment I could not tell which was Indian and which was turtle. In the general confusion one man was sent rolling over and over at a blow from one of the flippers; in an instant he was on it again, and then the struggle was over; the turtle was turned on its back, hauled to a safe place, and we returned triumphantly to camp.

The next morning four Indians said they would bring the turtle in with ropes if I would loan them. I thought they must be very strong, and rather doubted their. ability, but I gave 
them such things as they wanted, and, taking my rifle, followed, to see what they would do.

After a tramp of about three hours, we reached the turtle, finding it unharmed and just as it had been left the night before. The Indians began at once tying up the turtle for the return to camp. I could not help admiring their ingenuity. A rope was tied to each flipper, when the turtle was allowed to crawl back to the water, where the Indians, holding the ropes from the shore, could guide it as they wished. We went toward camp with some enthusiasm at the thought of the supply of fresh meat that was swimming along before us as we walked rapidly over the hard sand.

Presently we came to the mouth of a river, where we all crowded into a small canoe, one man holding the turtle, and three attempting to paddle. But the turtle was too strong for us, and began at once dragging the canoe down the river toward the breakers on the bar. Here was danger; around us an ever-increasing company of sharks came, gathering closer; some even brushed against the canoe, rocking it violently, while the efforts of the turtle threatened to upset us every moment, and once in that water 


\section{AND ACROSS PANAMA}

there would have been little chance for us. We were now nearing the breakers, and the canoe began to race ominously. I called to the men to cut the ropes and let the turtle go. One seized the hatchet, but at that instant the turtle turned down the coast instead of crossing the bar, and this gave the Indians a chance to reach the other shore, and we soon had the turtle hauled up close by camp. That night he was made into soup, a whole turtle stewed in a great iron pot, and it was good.

As the days went on, my companions continued to drink freely, and presently the camp ran dry, that is, all the spirits had been consumed. This wasn't my fault, and I was rather well satisfied; but my companions were most unhappy, and the superintendent ordered that I immediately provide the money for a fresh supply. I had all the funds for the expedition, which, in some respects, was fortunate, though I hardly think that expedition would ever have gone to water; yet, except the money had been in my hands, it would never have gone very far.

After thinking for a few moments, I declined to provide more drink, and prepared to face a 13 
storm, which came on in good earnest, - a wind of words before which I finally weakened. I was still very young then, and had frequently read of the necessity of spirits on an exploring expedition, especially for snake-bites, exhaustion, etc.

I decided to go myself to a trading-station some miles away, and bring to camp six bottles of cheap liquor, - a mixture of alcohol and other things, called brandy, which ought to have been more fatal than a snake-bite.

Taking two Indians, I started for a long tramp to the trading-station. There was little of incident, but much that was beautiful, the influence of which was probably enhanced by the sense of harmony and the satisfaction I had left behind among the members of the expedition. Through dense jungles, the trail led on and on, the Indians never hesitating for an instant, till finally we reached an open savannah, where we stopped to rest, with a beautiful expanse of green before us, containing some square miles of grass, dotted with groups of fine trees, through which the distant mountains could be seen, a bold outline in beautiful prospective. 


\section{ANDACROSS PANAMA}

Starting on again, we presently came to the traders' camp, where I bought six bottles of brandy, and, after resting my men and giving them a feed, started back for camp, each Indian carrying three bottles of the brandy and looking the picture of misery while they trudged along in front of me, endeavouring to get away by themselves. Finally they became worked up into such a state of excitement that, for safety, I promised to give them each a drink when we got to camp, and after that I could not go fast enough for them.

At sunset we reached camp, and all came crowding around eager for brandy. One bottle was given to the superintendent, who immediately partook liberally himself; and then he began treating all hands, and soon came back for a fresh supply. But I had placed the five remaining bottles in a suitable box, nailed down the lid, and put my seal over the cracks, as one does when shipping bullion; then I announced that that brandy was mine, and threatened all the law and prosecution of the courts on any one who dared to break my seal. Then there was a racket, before which I winced and trembled, but would not give in; for, though I was 


\section{AROUND THE CARIBBEAN}

afraid all through, I was mad also, and that helped me out.

It was amusing to see the superintendent look at the impression of my crest on the box, and then turn away doubtfully and consult with the Spaniards; but they seemed to consider that I had the law on my side, and it is remarkable what a little thing will hold men in check. Finally the camp quieted down, and after a cold supper I went to bed. Before I turned in, the cook, a rough fellow named Brown, slapped me on the back and said, "Wal, now, for a kid, that war purty well done," and then he went away laughing. I was very indignant that any one should call me kid, and went to sleep planning how it should be stopped. 


\section{A N D A R OSS PANAMA}

\section{CHAPTER III.}

\section{INDIANS AND MOSQUITOES}

Now the days dragged and time was heavy on our hands, and it appeared as though the Indians never would be ready to take us on, but one morning a whole fleet of canoes appeared, brought by a goodly company of Indians who had come to take us to their village.

Under the direction of their chief, our goods were shortly distributed among the canoes, and in a long procession we started across the lagoon, a sheet of water formed quite the same as the shallow lagoons along our Atlantic coast, but surrounded with vegetation of bewildering density. The water was very shallow, and the canoes made good progress. After some hours we saw in the distance a collection of cocoanuttrees floating as it were above the water. They mark one of the principal towns of the Mos- 


\section{A ROUND THE CARIB BEA N}

quito Indians, a place where dark stories linger, tales of the Indians and their cruelty. Arriving at this place in the late afternoon, I saw only a low, muddy shore, and groups of huts clustered together among the trees.

As we came up to the landing, women and children crowded about, talking eagerly, and anxious to see everything we had. Climbing over the side of a great canoe, I stood for the first time on the native land of the Indians, and it would have been hard to tell which were the more interested, I or the Indians crowding about me. The girls were graceful; the younger ones beautiful. The children were bright and pretty, like little fairies, almost; but the older women were worn and bent by labour. The men showed all too clearly the signs of unrestricted dissipation. They were of rather dark skin, and among some there were marked traces of negro blood. Their huts were oblong, rounded at the ends; they were made by driving palmettotrunks into the ground and covered with a thatched roof of palm-leaves. The children wore but little clothing; the women used a short skirt and little shawl, and the men wore pantaloons and a short coat, only partially cov- 


\section{AND ACROSS PANAMA}

ering the abdomen. All were friendly, and in a very short time willing hands took our supplies from the canoes, and then made us welcome, with presents of fruits and game. All our things were stored in one of the larger huts, and we were given a place near by, in which we were to live, - a very comfortable hut, with mahogany boards for the floor.

Soon people grew tired of looking at us, and went about their own affairs. The women busied themselves preparing food, and presently seated before the huts were groups of people, eating; talking, and laughing, evidently secure in the abundance of the present and the promises of the future, with no care at all.

In a little time the family groups began to disappear, and laughing and talking could be heard from under heavy canopies; and from the surrounding jungles a distant hum, rising up and dying away, could be heard constantly growing louder, and apparently drawing nearer. Most of the people had disappeared by this time, and the chief now shouted to us, "Get under the mosquito canopies; don't you hear them coming?"

We had been provided with canopies before 19 
leaving the settlements, and, finding that the Indians had been careful to hang them in our hut, we hurried under cover. For a time I lay awake, listening in wonder to the myriads of mosquitoes that came swarming about. This was the Mosquito Coast, and I began to understand how, at night, the mosquitoes are a real danger, and to sleep without a heavy canopy would truly mean death.

A day or two later, in the early morning, when the fog was thick among the marshes, and the mist hung low over the water, I left the little Indian village under the cocoanut-trees on Brewer's Lagoon, and began a long journey, canoeing up the Rio Patuca of Spanish Honduras. I had been pleasantly entertained at the village, but my late friends were apparently so indifferent at my going that I began to lose faith in the Indians, while stories that I had heard of their cruelty and treachery were constantly suggesting themselves to my thoughts. My white companions were rough, boasting; quarrelsome men, not pleasant travelling companions; and from them I separated myself, and found a comfortable place in one of the smaller canoes alone with three Indians, about 


\section{ANDACROSS PANAMA}

whom I really knew nothing. Soon the Indian village was lost. in the gray light of the morning, and then we were surrounded by fog and desolation. Along the shores of the lagoon were dead or dying trees, gaunt and naked; about us were quantities of water-fowl, and in the water were many watchful alligators. Our progress was slow, for the shallow water was choked with plants and decaying vegetation. About noon we made a branch of the Patuca River, where a volume of muddy water came pouring out of a narrow channel, surrounded by great stretches of marsh land covered with tall reeds and extending for miles. Progress was slow, and the clumsy boat designed by the superintendent of the expedition could scarcely be held against the current.

By nightfall we had made perhaps one or two miles, and then, the mosquitoes appearing, we were forced to prepare a hasty camp on a mud-bank. Such a night! Before my mosquito bar was up, I had caught a net full of them, and as the hours wore away held a boxingmatch with myself, and perhaps killed some mosquitoes, but I am not sure; in that country mosquitoes are different from the harmless little 21 


\section{AROUND THE CARIBBEAN}

insects at home. They are like rubber; to kill them one must use force enough to cause some inconvenience, and that night I punished myself severely. Next morning came with fog and light rain, just the weather for mosquitoes; and the Indians predicted that we would have a bad time. We didn't stop to eat much, and were soon under way again, making better progress than on the day before. I travelled with my three Indians, who were working vigorously to keep up with the larger boat. They were almost naked, and the quantities of mosquitoes made their flesh quiver; yet they bent determinedly to their work. Presently we passed under a group of willow-trees, and I picked a bunch of soft withes to keep the mosquitoes from my hands and face. One of the withes was very long, and I found that by using a little energy I could send it gently over the backs and shoulders of my suffering men, and at the same time protect my own face and hands. Presently my white companions noticed my efforts, and from the larger boat set up a derisive shouting, saying, with many unpleasant words, that it was no use to do anything for an Indian, I would learn quickly enough. The Indians said noth- 


\section{A NDACROS PA A M A}

ing; neither did they make any sign of thanks, though at each derisive shout and taunting remark I noticed an ugly light flash in their eyes, but there was no other change of expression. Then we fell behind the big boat, and I was alone with them. Dinner-time came; the big boat was far in advance of us, and my men had nothing to eat. Their leader asked me, "You eat now?" and on being told that $I$ would, stopped the canoe at a convenient point and spread out the bountiful lunch that had been provided for me. Then they went back to the canoe and sat in stolid dejection, waiting for me to finish. I immediately called them, proposing to divide what food I had equally. They came with some hesitation; each took the offered food, but made no sign of thanks, not even an expression of gratitude on their faces. My dog received a share of the food, and it laid its head affectionately on my knee and wagged its tail in appreciation; but the Indians simply ate, and made no sign. I was disgusted. Truly there was reason in all the derision of my white companions. We started on presently, but there was a sort of misunderstanding among us. I sat in the canoe, brushing the mosquitoes from 


\section{AROUND THE CARIBBEAN}

my hands and face, and let the men shift for themselves, thinking that there was no use doing anything for an Indian; but common humanity could not bear the sight of their quivering, naked flesh, and the next moment I was brushing the mosquitoes from them, as before, wondering at their strange, unfeeling natures.

Late in the afternoon we overtook the large boat, and found that preparations were being made to camp on a high, wooded bank, that promised well for the night. I got out my mosquito bar, meaning to arrange it early, before the mosquitoes came; but no sooner had I started for the shore than the leader of my men gave the youngest a savage cuff across the ear and pointed to the bundle, which the young man immediately ran to take from me. I was well tired, and only too pleased to give it up, and scarcely noticed that my men were busily at work arranging it for me - and they did it well, too. When supper was ready and we sat around eating as best we could hardtack and canned corned beef, with strong coffee, one of my men came softly behind me and put a fine piece of roasted turtle on my plate, and went away, not even waiting for thanks. Of course, 


\section{A NDACROSS PANAMA}

I shared it with my white companions, and we all found it a welcome addition to our limited supply. Then the mosquitoes drove us under our nets, and we tried to sleep; but a fierce storm, now rapidly approaching, made us anxious, and we lay awake waiting. The perspiration was trickling down my face; then for a moment a breath of cool air came, blowing through the net, followed by a crashing and roaring as the storm closed in around us, wind, thunder, lightning, and torrents of rain. No tent could turn such a volume of water, and presently it was coming through in streams. All the place was drenched, and pools of water formed where my companions had made their beds; but where I lay the ground had been banked up, and no water collected, and for some unaccountable reason no water came through my part of the tent, though long, bitter curses, coming from my companions, showed how they were faring; yet I was cool and comfortable and presently fell asleep.

Morning came bright and clear after the storm, and, on scrambling out from under the tent, I saw that my Indians had left their beds, and in all that storm had collected quantities of 25 
big leaves and arranged them on the tent over my bed, that I might sleep unharmed. Truly their ways are not as our ways, and it is of some use to show kindness to the Indians. I understood them after that, and we were the best of friends. Through all that journey I had but to express a wish, and eager hands were ready to serve me. Of course I shared my provisions, and kept the mosquitoes off them; but that was not much to do, and they gave in return of fruits, game, and all that they had; nor were they ever contented till I had taken the best of everything that they secured; yet never an expression of thanks in their silent faces, only now and then a light in their eyes that shone for an instant and then disappeared. Through all that trip up the river the water was at full flood, the rainy season on in force, and all nature at its best. Each turn of the river opened to new delights of tropical luxuriance, a wall of green on either hand, a torrent of muddy water crowding, chafing, and filling the air with a subdued, but ominous, murmuring; bands of dark, forbidding clouds, beating showers, with alternate periods of bright sunshine, and everywhere the fragrance of count- 


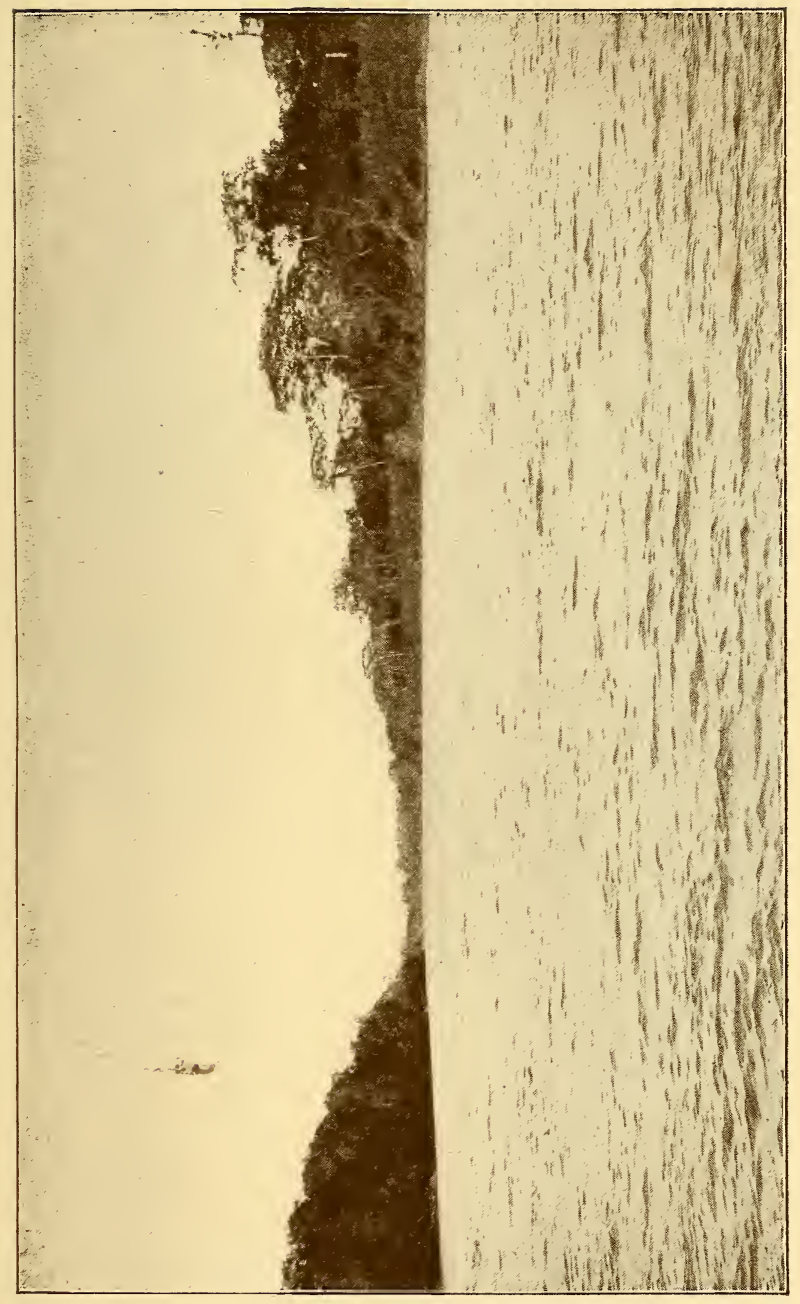





\section{AND ACROSS PANAMA}

less blossoms. Of all that was beautiful, the most striking were the masses of yellow jessamine flowers that in some places, where the vines had mounted to the tops of great trees, were seen in bold outline above the forest, a crown of glory and fragrance. It was beautiful, but no place for a white man. Below the dense luxuriance of the jungle were swamps and poisoned air, and all that region was solitude, given over to wild animals and primeval forests.

Camping in such places was not pleasant, and each night we made the best convenience we could on a mud-bank, and, though my Indians did everything possible for me, I was beginning to be quite miserable, when my head Indian said, "Don't sick; we sleep dry to-night, and to-morrow reach houses!"

Our camp that night promised to be the most unpleasant of all, and, to my surprise, the Indians did not arrange my bed and mosquito bar as usual. I soon found they had not forgotten, for after supper they came to carry me on their strong backs two miles through the swamp to a village of their people. My white companions objected, saying, "You are a pretty fellow, going to leave the expedition, making up to the 27 


\section{AROUND THE CARIBBEA N}

Indians, and deserting your friends. Suppose the river rises, and everything exposed to it." I stopped, not that I cared much about my "friends," but I felt some responsibility for the goods we carried. The Indians were disappointed, and the youngest of my three men was told to stay with me. Of this there was no need, and I sent him, to be comfortable, with the others. Then night settled down about camp, and the sorrows of darkness began, rain above, mosquitoes around, and mud below us.

At last morning came, and the Indians returned from the village looking fresh and rested; but we, who had stopped on the mudbank, were a sorry appearing lot. That day it did not rain so much, and the Indians worked with a will, so that by noontime we reached an open savannah, where a collection of board houses and a ruined sawmill were lonely evidences of an enterprise of some kind that was a failure. Here we were to stop for a few days, until arrangements had been made with other Indians to take us further on. Our supplies were soon unloaded, and then the Indians turned away and left us, my own men going without 


\section{A ND ACROSS PANAMA}

a word or a look. I hurried after them to say good-bye; and when I called they stopped, took my proffered hand with a surprised expression, and then went on again. A moment or two later the boats disappeared around a bend in the river, and I never saw any of them again. 


\title{
CHAPTER IV.
}

\author{
WILD ANIMALS AND A PANTHER AT NIGHT
}

Afrer the Indians had gone, we settled down to camp again, this time at an open savannah surrounded by jungles. The superintendent of the expedition soon found himself in difficulties. He carried a heavy equipment, which Indians living near, and on whom we were depending, said could not be taken up the river to our destination; and thereupon a contest of wills set up, the Indians offering to take us on with a light equipment selected from among our things, and the superintendent vowing that all the material should go forward. I liked the plan proposed by the Indians, but could do nothing except advise, as my instructions were to follow the superintendent for a time at least.

Our camp was not altogether harmonious, yet there was much of real interest in our surroundings, with occasionally an exciting incident. 


\section{AND ACROSS PANAMA}

Every night jaguars, panthers, and tiger-cats came prowling about the camp, filling the air at intervals with their strange cries. The tigercats were not dangerous, but the jaguars and panthers caused us some alarm. Of all the sounds in the tropical forests, the cry of the jaguar is the most awe-inspiring. From all the tangled growth of the jungle, a myriad of minor voices constantly fills the early hours of the night; then a volume of sound breaks in on the harmony of sound; a roar ending in a sudden choking, and all is still; from the forest no sound arises, the jaguar has cried out on his pathway, and all nature pauses as if in fear, then, reassured, the voices of the minor animals begin again, and presently are heard as before.

One night $I$ heard the voice of an unusually large jaguar coming nearer and nearer to camp; then presently its deep cry was heard close by the houses, and all was still. It was probably coming in, but where? Of course not from the place where it had last cried out; perhaps it would sneak along the river-front, or come crawling in through the long grass of the savannah. While I waited listening a soft foot- 


\section{AROUND THE CARIBBEAN}

fall was heard just by the house, and then a stealthy step coming through an open room or piazza. It is preparing to attack, was my first thought. My bed was most exposed - in fact, nothing but a door, covered with cheesecloth to keep out the mosquitoes, separated me from the piazza. I sat up listening, and fancied I heard a deep breathing. I called softly to my companion, got up, found my pistol, and stood waiting. Everything was still. Then I whispered, "Let's go out and try for a shot."

My companion whispered assent, and then said he would open the door, and cautioned me to be ready if the jaguar should spring through it. Then he whispered, "Ready?" opened the door, and - got behind it. A breath of fresh air blew in my face, a shiver went down my back. That was all. An instant I stood waiting, and then stepped out. But the animal had gone as stealthily as it had come. Then out came my companion, all big words and flourish. Together we went about the camp for a time, hoping for a shot. Then the mosquitoes drove us in, and we went to bed again.

As time passed, wild animals became more troublesome. One night we were awakened by 


\section{AND ACROSS PANAMA}

a great outcrying and cursing coming from the cook's quarters, and on hurrying out found the cook with a big club in his hand, and two or three frightened Indians standing behind him.

"Them animals beats everything I did see," he said, as we came running up. "But the cheek of the brute! It sneaked right past my mosquito-net and went to eating at the meat I had saving for breakfast. I drove at it with this club, and it got away, through a hole, I take it."

"What was it?" we all asked.

"Panther - yellow and big enough for me, anyway," and the cook looked at us as if to say, "Those animals are not dangerous ; it's all Indian talk." We advised him not to attack panthers with a club at night, but if the thing came again to call us. Then, after talking a little, we hurried to our mosquito bars, not having noticed till then how the insects were swarming around us.

Next morning the cook said to me: "Mr. Frank, I thought it was a lot of rats or I wouldn't have done it, but I ain't telling that to them men," pointing to my companions. 


\section{AROUND THE CARIB BEAN}

The next night, shortly after we went to bed, we heard the cook calling again, and hurried from our quarters to his aid. As we came running up, his voice greeted us from under the mosquito bar, saying, "That panther has come again, bigger this time, and it's gone in the cook-house."

We went cautiously and stood looking in at the open door, where there was quite a large room, now perfectly dark. We stood there a moment; then I told the engineer to hold a torch over my head, and I would go in the room and try for a shot at the panther. There was but one door, and I felt sure of a shot this time.

The engineer called me a blank, blank fool, a kid, a tenderfoot, and said he would hold no light at that door.

"Well," I said, "I'm not going to miss this chance. I'll go in without a light."

"Yes," sneered the engineer, "tenderfoot, fool, kid. Don't you know better than that, going in a room with a panther? You never saw one before, that's plain. Any mother's baby would know better." 


\section{ANDACROSS PANAMA}

I stepped up to the door, saying, "Are you going to hold that light?"

"Here," he said, "give me a torch. Now go in and let the panther maul you; it will serve you right."

He held the torch at the door, and I stepped cautiously into the dimly lighted room. At first I saw nothing, and stood for what seemed a long time, the engineer telling me to come back while I could, and that the brute was only hiding. I didn't like it very much, and had just determined to back cautiously out when I heard something stir, and then over in the corner above a pile of flour-bags two burning eyes appeared, glared at me, and were motionless. There was the game. My chance had come. I raised my big .44-calibre revolver, took careful aim, shot, and then repeated, aiming at the same place. Something fell heavily to the ground, the engineer gave a sort of gasp, and exclaimed, "The tenderfoot kid, he did kill it." Then everybody crowded into the room.

We searched with great care, but could not find the animal. The general opinion was that it had been badly wounded, and had crawled in behind some of the stores, and we could get it 35 


\section{AROUND THE CARIBBEAN}

in the morning. I moved a barrel and caught sight of a tawny fur, and made a grab for it, but one of the men caught my arm and held me back, saying, "Those animals have more lives than a cat; better be careful." However, the beast lay perfectly still, and I wanted to see it that night, and I put my hand down, feeling it carefully for a moment, then took hold with both hands, braced myself, laid my strength on for a big lift, and went over backward as if I had lost my hold. But I hadn't. My grip was good enough, and so had been my aim; but in my hands I held an unfortunate opossum, and not a very large one at that, except its eyes, and they were too big for its face.

I didn't mean to hurt that opossum. It wasn't fit to eat. I had nothing against it. Why couldn't it have gotten out of a hole in the roof before I shot, and have made big noise getting away? Then I would have had a thrilling tale to tell of adventure with a panther. As it is, I only killed a night-prowling opossum, of the kind that smell badly when one gets too near them. 


\section{A NDACROSS PANAMA}

\section{CHAPTER V.}

\section{ALONE IN AN INDIAN VILLAGE}

As the days passed one after another, I made friends with the neighbouring Indians, and found them a kindly disposed people, but they were positive that the river was too rough for our heavy equipment and clumsy boats, so the deadlock continued. In camp, when troubles come, life is a serious problem. The superintendent went to look for men, insisting that his boats and heavy equipment should go up the river, wildly declaiming as he left us that the world contained no torrent strong enough to turn him aside or check his plans.

We were alone now; for days the neighbouring Indians had refused to come near our camp. The engineer was dangerously sick, and the cook objecting violently to the burden of work. That morning he said to me: "Mr. 37 


\section{AROUND THE CARIBBEAN}

Frank, it ain't no ways reasonable, me to be cooking and cleaning, cutting wood and fixing stores; and with him sick and kicking mor'n enough, there won't be no getting along with it." Then he sent the axe crashing into the log he was chopping, and, shouldering a quantity of wood, marched away to the kitchen. Just then I heard the engineer asking for water, which I hurried to give him. Something had to be done. Salt provisions and heavy work promised to make us all sick. It was still early in the morning. I knew that seven to nine miles across the jungles and savannahs there was an Indian village, and I resolved that I would go there and find help. I took my rifle, gave some directions to the cook, and hinted to a little Spaniard who hung around camp that if he would mind his own business it would be appreciated. Then I hurried out on the trail to look for help. I had never been alone in the tropical jungles, and was all excitement with a sort of fear because of the unknown in the wilderness about me. Gradually this feeling wore off, and, as the day passed, my only anxiety was that night might come before I could find the Indian village. I knew that it was a long way before 


\section{ANDACROSS PANAMA}

I started, but now as the narrow trail led me on and on, sometimes through a dense jungle, again in and out and among the great trees of an open forest, or through tangled bushes along the edge of the savannah, it seemed as though I would never reach the end, and now anxiety and fears of a lonely night in the jungles were my constant companions. I was alone, and, perhaps, like a lost man, becoming panicstricken; yet I hurried on, and late in the afternoon saw a group of trees and little houses some distance ahead across the savannah. Urging my steps, I presently reached the village, tired and hungry, only to find the place deserted. Sometimes the Indians go away for days, and I looked anxiously for signs of life. Then from one of the houses I heard voices, and on hurrying to the door and looking in, I saw one of the most beautiful examples of Indian life that I have ever known. The house was full of children, little and big, all perfectly contented, talking together and laughing pleasantly. The boys were mending bows and arrows, or swinging in hammocks. The girls were busy at miniature housekeeping, and the very little ones were either asleep or staring contentedly at the 39 


\section{AROUND THE CARIB BEA N}

others. Outside it was all burning sun, but in the hut there was subdued light and cool air, like that of the deep woodlands.

For an instant, I watched the half-naked children, as healthy and graceful as little wild animals; then they saw me. The bigger boys caught up their knives, their bows, and their arrows, and stood defiantly in front of the girls; but just for an instant; the next moment some of the boys who had been at our camp recognized me, weapons were thrown aside, and I was receiving a welcome such as can be had only in the boisterous good-will of healthy children. Then some got a hammock for me, others took off my boots, while still others ran to bring fruits and cool water. In a very short time I was most comfortable, and had quite forgotten the burning sun and long tramp. Presently some of the children came, bringing an old woman - the grandmother of all the village. She could speak a little English, and on learning that I wanted some men, said that they had all gone hunting, but would come back at night. Then she had the children gather up my things, and we all went to her house, where 


\section{AND ACROSS PANAMA}

she and some younger women immediately began preparing a good dinner for me.

When all was ready $I$ was brought a large wooden plate, and the food was placed around my hammock in gourds, each presided over by a bright little Indian child, armed with a forked stick, with which to pick up the food and transfer it to my plate as I might want it. I had boiled chicken, rice, yams, plantain, smoked wild pork, yucca, and various fruits. The children were eager in their service, and it was a beautiful dinner. Before me was the intense sunlight and deep blue sky over the open savannah, around me a pleasant shade and soft breeze blowing in at the wide-open door, and the children, pretty little creatures, laughed and chatted together, each eagerly pressing me to eat of what he or she had to offer; while the old Indian woman sat looking on, all smiles at my enjoyment of her things, her satisfaction increasing every moment, and I must confess that I did eat a lot, but then there was plenty. After dinner I amused the people showing them my watch, compass, and the few other things I had with me, and presently evening came, and with it the people of the village: men laden 


\section{AROUND THE CARIBBEAN}

with game from their hunting, and women bearing fruits and vegetables from their gardens and cultivations among the woodlands.

So soon as my Indian friends learned that the superintendent had left camp, they were all quite ready to go with me, but I wanted only two men, and, having picked out a pair of sturdy-looking fellows, we all went to the chief's house to sit around and have a talk. The children came, too, but now they were quite subdued in the presence of the men, and sat meekly looking on. From time to time women came in to look at the white stranger; each carried a torch, and generally an armful of gourd dishes, all very much alike, which probably they had been washing; these were all laid on the ground in front of the house, while the Indian women came in to satisfy their curiosity. Presently one came along with her torch and a good supply of gourds in her arms. She placed them on the ground with care, laying the torch beside them, and came stalking in with a savage look at the boys. Evidently she was no favourite with them; there was a whispered consultation, then the little scamps sneaked cautiously out of the door, went to her torch, and 


\section{A NDACROSS PANAMA}

carefully made two torches of it, putting each in a separate place a little distance apart; then they divided her gourds, placing some by each torch; after that they hid behind some bushes and waited. Presently the woman, having satisfied her curiosity, went out, and walked up to the nearest pile of gourds with a puzzled expression; she had brought eight, now there were only three, with a small torch, and hers had been a big one; then she went to the others, then she came back to the first, and went angrily toward the others again. Evidently she wished to be careful about touching what might not belong to her, and now stood looking about her with an angry, puzzled expression. Then a stifled laugh came from behind the bushes; instantly she seemed to grasp the situation; with one sweep of her long arm she gathered up her gourds and made a dash for the boys, but they were too quick for her, and, scattering in all directions, the half-naked little scamps went dancing about among the houses, screaming with laughter and delight at her efforts to catch them. For some time she kept up an angry, determined chase, but finally gave in and went to her hut, with loud expressions of opinion that 


\section{AROUND THE CARIB BEAN}

sounded like very bad words. The men laughed heartily, and, encouraged by this, the boys came with doubtful steps into the house, but the chief made a sign to the young men, and the boys made a wild dash for the door. It was no use this time; they were soon caught, their ears were soundly boxed, and for a time lamentations filled the village.

I talked with the Indians late into the night, and then slept on a mahogany board under a good mosquito-net, and would have been comfortable if only I could have found one soft spot on that board. In the morning I and my two men tramped back to our camp, where the Indians soon made us comfortable. 


\section{A N A CROSS PANAMA}

\section{CHAPTER VI.}

A StartuIng PRoposition AND A HEAvy FLoOD

For a time the days went on pleasantly enough, but after awhile we began to feel somewhat anxious about the superintendent, and as the days lengthened into weeks we talked of sending out a searching party. Then word came to us that yellow fever was raging all along the coast, and that the superintendent was dead. At this we decided that our plans must be changed, yet to go back to the coast seemed unwise; and finally it was agreed that I should go on alone to the interior, and that our two remaining companions should stay with our supplies till men and proper equipment could be sent down the river to take them all to our destination.

Arrangements were easily made with the Indians, for they were all eager to serve me, 
and a few days later I left camp in company with a number of them, who had come to take me to their village, the first stopping-point on my journey to the interior. A moment of mutual parting, instructions, a hurried good-bye, and I turned away with my Indian friends. As we went, they talked continually of the rich beauty and resources of their country; for what reason I did not know till I arrived at their village, where I found a number of leading men, who, after extending salutations of welcome, made me a rather startling proposition. It appeared that four villages in that country were constantly at strife, each with the other, and they wanted a new chief to preside over all four, a dignity to which I had been duly appointed, and they proposed to build me a new village, or, rather, a collection of huts, where it was proposed that I should marry and settle down, but the marrying was serious because each of the four villages expected to be represented in my establishment. First I was to marry a daughter of each of the village chiefs, - that made four as principal wives; then I was to marry a relative of each chief's principal wife, one from each vil- 


\section{AND ACROSS PANAMA}

lage, - that made eight; then, after marrying eight Indian girls selected for me by others, I was to select a wife from each village as I might fancy; a total of twelve wives offered all at once.

The Indians could not understand why I did not accept at once an offer so liberal in all its conditions, and I was anxious enough to find some excuse for declining without giving them offence. After we had consulted together for a long time, I told them that, according to the laws of my fathers, which were of course binding on me, a man could have but one wife, and that I could by no means become the common bond through which the contending villages might be united. Yet I was fearful of offending their women, for they were proud of their attractions.

There was a beautiful little Indian baby girl about four years old in that village, named Dropín, and just at that time she happened to be sitting on my knee looking at me intently with grave, wondering eyes. So I told the people that I could not be contented with any one but Dropín, and as she was so young, I would have to wait for her to grow. The people were 47 


\section{AROUND THE CARIBBEAN}

disappointed, but accepted the excuse, and little Dropín became a personage of importance. Then I gave her a lot of things, such as I had, a bright silk handkerchief, metal buttons, safety-pins, etc.; and her delight was beyond her ability to express. Then I nominated a boy to take care of her, which was equivalent to providing a husband, gave the chief some money to buy her a cow, and I had done sufficient. No doubt $I$ have long since been forgotten, though, for myself, I often think of the pretty Indian baby and wonder what has become of her.

In the same village I met a boy who some days before had come to camp, asking that I would give him some medicine for ugly sores and a skin disease on his legs and feet; and I was pleased to find that he was now quite well. He could not speak my language, but as a means of expressing his thanks he came to show me the places where the sores had been, and then stood by my side till late in the evening.

That night it rained, and in the morning the river was up and a mighty flood was on; all around, where yesterday there had been green savannahs, was one expanse of water, 


\section{A N D A ROSS PANAMA}

and the higher ground on which the village stood was an island, with the water still rising around it.

Even the Indians looked on in amazement. Then a rumour started that my friends at camp were being washed away, and that most probably all would be killed.

I called my men, and told them to go back to camp, which was within easy reach now by canoe across the flooded savannah, and help could be sent quickly; but the men said they would not go; it was too dangerous. In vain I scolded and entreated, they would not go. Their engagement to go up the river they acknowledged, and were prepared to obey any orders for that trip I might give at any time. Then I determined to gain my point with strong words. So calling them to the canoes, I said, "Get your things, we will start now."

The chief translated, and dismay filled their faces. I took my place in the canoe and repeated my order. "But we will certainly be killed," said the chief, " no canoe can live in the rapids just above here with such a flood."

"Good," I said, "we will all be killed; so will my friends unless you go to their aid, and 


\section{AROUND THE CARIBBEAN}

why should I not die with them? Now take your choice, go down the river to help my friends or start up the river with me at once, and we will all go to 'Hell' together."

They looked at me, and I looked at them. Then the chief said, "Me go," and after that they all assented.

It was easy for them to push a light canoe across the flooded meadows, and that evening they all came back, the chief bringing a letter from my friends assuring me that they were all well at camp.

Later, I heard that the chief had expressed a rather strong opinion in regard to my character, saying to my friends at camp, "Yes, he a good man, he a much good man, but, oh, God, he a devil." 


\section{AND ACROSS PANAMA}

\section{CHAPTER VII.}

\section{A ROW IN CAMP}

The next day word came to me that the superintendent had returned, and was most anxious that I should come back to camp, which I naturally prepared to do at once.

The river was still at flood, though the savannah was now free from water. Two fine young Indians were directed to take me, a canoe was prepared, and we were shortly on our way, the swift current carrying us down the river with almost appalling force. It was a long way, for the river made numerous windings, and it was late in the afternoon when we arrived in camp. I was surprised to find that a number of my Indian friends had also come to our camp, having made their way, through all the dangerous wind, across the lately flooded savannah. As I went toward the house, one of 


\section{AROUND THE CARIB BEA N}

them whispered, "If he fights, come out to us." Then they all sat about indifferently, and one would have thought they had no concern in me at all.

My meeting with the superintendent was strained. He had failed utterly in his search for men, and there was little to be said, at least I had nothing to say, and simply waited to hear him.

We were all sitting in front of one of the huts, I watching the sun set, and wondering at the volume of water in the flooded river just before us; then from the other side I saw a great animal come out of the woods, where for an instant it stood in bold outline against the sunset. "What is that?" I cried, "a tapir or what?" An Indian sitting near said, "Tiger," and in an instant there was commotion in camp. Supremely quiet, the great jaguar stood looking across the water; then with a slow movement, his eyes fixed on us, he walked to the river and began to swim as if intent on reaching where we stood and beginning the attack. $\mathrm{He}$ must have been well hungry to attack so many people, but a hungry jaguar will do anything. We rushed for our rifles, and before the jaguar 


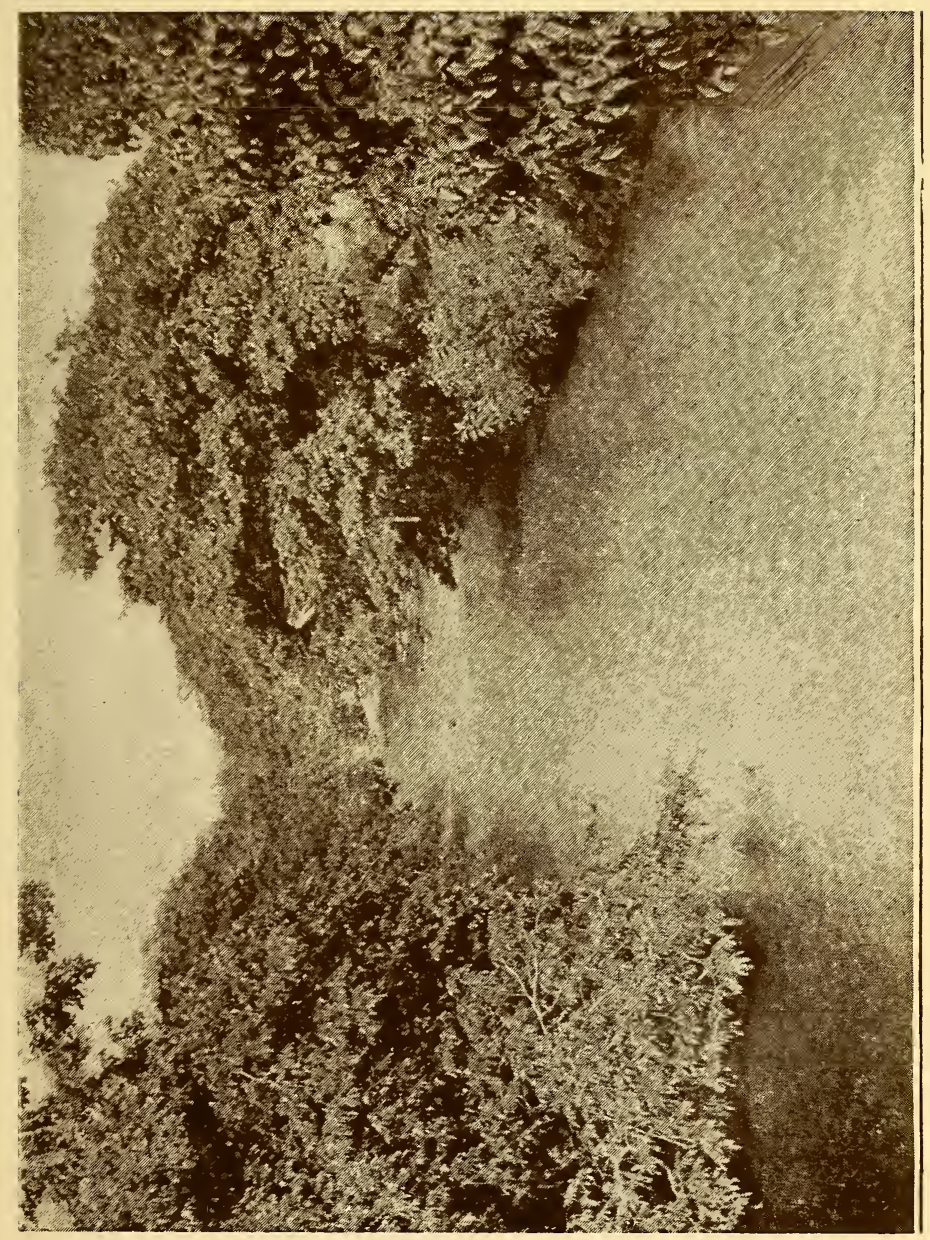





\section{AND ACROSS PANAMA}

could cross the broad river all were prepared for him. "You saw it, your shot," whispered one of the Indians, as we stood waiting. Then I stepped ahead of the others, feeling sure of my game this time. I wanted the skin, and had just determined to let the beast reach shallow water on our side of the river, feeling sure I could kill before it sprang on us, when one of my companions fired over my shoulder, taking my shot, and killing the game while it was yet in deep water. For a moment or two it struggled, making a magnificent effort to reach shore, then sinking below. the surface, disappeared for ever, carried down by the swift current.

This incident put us in a bad humour, and the superintendent began demanding money, asking that I should make heavy drafts on New York, though how he expected to obtain money on them in the wild jungles was past my comprehension. I agreed, however, that I would give him the drafts, provided he would take a light cargo and go on with the Indians to our destination. He refused, and after consulting my Indian friends, I decided that no more money could be given him unless he agreed to 53 


\section{AROUND THE CARIBBEAN}

go on, make such progress as he could, and give up his schemes in regard to navigating the Patuca River, in which I had no interest whatever. Then there was a scene, threats and wild language; the superintendent had been drinking, and was little better than a madman. Presently his thoughts centred on an idea that he would go back to the settlements, and up the road to the interior, and there revoke certain transfers of property before I could have them registered. This registry was one of the most important matters that had been entrusted to me. The question was rather serious, and I consulted with others before answering him; while he, all complacent, thought I was cornered.

I was assured that if he went back to the coast he could not get through the dead-line, because yellow fever was raging in the settlements. The dead-line is a rather peculiar though effective quarantine; a line is drawn across the road from an infected place, and a notice is posted up; a guard stationed to protect the line, and whoever attempts to cross from the infected side is immediately shot. I hardly believed this statement, but I was convinced that there was some impediment to travel, and that to reach 


\section{ANDACROSS PANAMA}

the interior from the infected coast would be difficult, and probably slow work. Fortunately we were above the dead-line, and I determined to make my way across the wilderness to the capital; if my companion came with me I could claim the right of registry, and if he went by way of the coast I could probably beat him in.

Once more I tried to persuade him that our best interests were to go on, but words were useless, and a race for the mines was in order.

I arranged as best I could. Of the money we had, I took one hundred and fifty dollars in silver, and gave the balance, several hundred dollars, to the engineer of our expedition, telling him to remain at camp till I could send help from the capital. Then, with the few things packed which were to be my outfit, I waited anxiously for an opportunity to begin my journey. 


\section{AROUND THE CARIB BEA N}

\section{CHAPTER VIII.}

\section{ALONE WITH THE INDIANS AGAIN}

IN a few days a crew of Sumu Indians came up the river and stopped for the night at our camp. They agreed to take me with them as far as they were going, but did not think I could succeed in getting over the mountains. They said that there were plenty of men at their village, a place called Gualpatante, and as I felt sure I could arrange with some of them, I determined to push on.

I got my things together and next morning we started. Their canoe was unusually large, made from a single mahogany log, and capable of carrying six or seven tons.

Eight men made up the crew, rough-looking fellows, such as I had never seen before, and I wondered what was to be my fate with them. The captain of the crew was old and bent, look- 


\section{A N D ACROSS PANAMA}

ing almost like a hunchback; his arms reached down below his knees; his neck was long, skinny, and protruding; he had only one tooth, which had grown up to the length of a boar's tusk; one eye was knocked out, his nose and chin almost met, his long, unkempt hair hung about his naked shoulders; and to make his appearance more frightful, one-half his face was painted black, which brought his protruding cheek-bones into peculiar prominence.

I looked at him in astonishment, not unmixed with fear, and he was in truth a strange, forbidding-looking object. The Indians quickly put my things in the canoe, the old Indian motioned me to a seat, and my journey had begun, my companion sneeringly remarking that he would wait for me at the capital, where I would find the property made away with, and all because of my headstrong folly in refusing his orders. The time for words was past; I invited him to go with me, but he would not; and then the men pushed out in the stream, and began a vigorous paddling which soon took us around a bend in the river, and I was alone with these strange, half-naked Indians, per- 


\section{AROUND THE CARIBBEAN}

plexed and doubting the wisdom of the course I was pursuing.

I was not long in finding out that I was in good company, and the strange old Indian was as careful of me as if I had been his child. I soon forgot my fears in the novelty of my surroundings, and then anxiety gave place to thorough enjoyment.

As we ascended the river the scene gradually changed, and presently we were among the first undulations of the mountains, and after two days, had reached the lower foot-hills, and were surrounded by all that one could dream of in a tropical paradise. At night we camped on the sand-bars, and in a few minutes the Indians would have game and fish in abundance. Then we would eat, and it seemed as if I could not get enough, and fortunately there was no end to the supply.

Two days more, and we reached the Indian village, a place called Gualpatante; the men took my things to one of the larger houses, and the people crowded around to see me.

I immediately began negotiations for men to take me on my way, and was meeting with some success when all my hopes were ruined at 


\section{A NDACROSS PANAMA}

a sign from the old Indian, whose name, I learned, was Tusa. He was a most remarkable person; the oldest people in the village said that when they were children he was just as I found him - old, temperate in all things, and powerfully strong. While we were coming up the river the men had on several occasions been unable to make headway against the current, which at times was very swift. Old Tusa carried a great paddle, bigger than himself, and at these times he would give one long sweep with it deep in the water, and the great canoe would tremble at the force; then another sweep of his broad paddle, and the canoe would move ahead slowly; then the men would get it in control again, and we would creep steadily on to quieter water; the old Indian making himself comfortable in a lazy attitude in the stern of the canoe. And this was the man who had me in his power, and I began to be anxious again, and wonder why he was unwilling that I should go on.

I was well treated, and if I could have spoken to them fluently or understood what they said, I felt sure that all would soon be arranged; but my few words of the Indian language seemed to 


\section{AROUND THE CARIBBEAN}

be lost on old Tusa, who spoke only a very little English and Spanish. Conversation was not brilliant. Each morning old Tusa would come down to see me and say: "Where going today?"

"Up the river," I would reply.

"No, can't go."

" But I want to - I must," I would protest.

"No, can't go."

"But I will," I would say, angrily, at times.

"No, can't go. Where going to-day? Stone tings; flower tings; butterfly tings; hunt?"

I was interested in collecting specimens, and would generally choose one or another excursion proposed. The old man would give a satisfied grunt, and then, after a brief direction to one of the young men, who apparently never thought of disobeying him, I would be taken out in the woods; and game, insects, botanical or geological specimens would be found to my fullest satisfaction.

But as the days accumulated, I gave up going out, and all my thoughts were concentrated on getting away from that old Indian. He would have taken me back to the camp down the river at any time, but he would not take me on, nor 


\section{AND ACROSS PANAMA}

would he let me go, and I began to fear that he had an understanding with the superintendent to detain me. Twice I nearly succeeded, but he stopped me each time, and I grew more and more anxious.

What he meant to do I could not tell, and I was in despair, even expecting that later he intended to have me killed.

The Indians were drinking a good part of the time, and how I learned to hate those drunken feasts. Tusa never went to them, but the other men would soon become hopelessly intoxicated, and then would promise to take me anywhere, and that would be the end of it, only promises. They drank fermented sugar-cane juice which was prepared by women who sat around a big trough chewing cane and spitting the juice till they had filled the trough; then it was allowed to ferment. When properly fermented, the boys would gather with their reed pipes and the men would drink to the accompaniment of their droning music, just the same thing over and over again, all in disorder, yet not unpleasing in its effect; and finally the men would fall into a helpless drunken stupor, though at times angry quarrels would take place, and the In61 


\section{AROUND THE CARIBBEAN}

dians, wild with drink, would threaten all sorts of violence. At such times old Tusa would hurry over to my house, and forbid my going out. Usually he stayed with me until the row was over, and I could not understand why he was so careful of me, and yet kept me so closely guarded.

A few days later I learned why this was. I had lost three weeks when a large canoe came up the river filled with Indians, but among them there was a white man, a fine fellow who was building up a trade in rubber with the Indians. I had been living in his house, and old Tusa proposed to deliver me safe and sound to my host. This he did with but little ceremony, and as he went out of the door he said to me: "Now can go," and walked off entirely satisfied.

My new friend said that the old Indian had done me a great service, as I would certainly have been killed if I had gone on without being properly prepared; and as it was he did not think it would be possible for me to get through, and advised me most seriously to go back, and give up the idea; it was no trip for a white man not accustomed to the most trying exposures. Then, if one did not die from the ex- 


\section{A N D A ROSS PANAMA}

posure, there were the wild animals; and if not these, then the Indians, almost as dangerous, and altogether he thought it would be impossible for me. But when I explained the situation, he said he thought it was taking big risks, but he would do the best he could for me.

He told me I might take my choice of evils. He could give me Mosquito men who would take me up the rapids safely, but might lose their way in the woods, which would mean death; then he could give me men from his village, but though they knew the trail well, they would perhaps have an accident in the rapids; which, if it did not kill me, would certainly mean the loss of all my things; or he could give me the wild men, who would be coming down with their rubber the next day. These were perfect river hands and sure woodmen; but they were murderous, and not to be depended on, yet if $I$ was careful with them they would probably take me through safely. I determined to cast in my lot with the wild men, and then my friend gave me careful directions how to treat them. Their last murder had been to secure forty dollars silver, quite a fortune to them. I now had only one hundred dollars silver, little enough with the

63 


\section{AROUND THE CARIBBEAN}

journey ahead of me. This I was not to show on any account. Then I was not to give them directions, but simply allow them to take me. I would fall in with a tribe called the Piyú Indians, some of whom were very dangerous, and, though cowardly, would sneak up to one at night, cut one's throat, and run; and on no account was I to sleep in their houses till I got to the interior valleys; where they were perfectly reliable, and I would be safe.

Then I gave my friend the money to pay the men, and he proposed to tell them he was advancing it to me, and that I had none. He said he would engage three men and two women as my guides and pack-bearers, because the men rarely murdered a person when the women were near. 


\section{A NDACROSS PANAMA}

\section{CHAPTER IX.}

OVER THE MOUNTAINS WITH INDIAN MURDERERS

THE following day preparations were made, and, true to their appointment, the men came down that morning, a whole lot of them, with several canoe-loads of rubber. I was glad to see that a number of women were with them, and was overjoyed to learn that they proposed to go back to their mountains the next morning. They looked as wild as monkeys, but their stout muscles spoke well for their ability as wood and river men.

A bargain was quickly made; my friend gave them their money, and, after making some presents, in which old Tusa was especially remembered, I set out again with a fair prospect of reaching the interior settlements. The first day the men did excellent work, and the next reached the Wampoo River, and continued on 65 


\section{AROUND THE CARIB BEAN}

the way to their village at a junction with it and the Po River. It had been a long, hard day's work for them, and just as I was congratulating myself on our quick time they announced that they must rest one day before starting out again.

There was no help for it, and so I determined to amuse myself as best I could, and when night came I began to think the time had not been a loss, for these were a strange people, and it is seldom the lot of a traveller to fall in with them.

That night the etiquette of the woods required that I should hand my firearms to my host, to prove my confidence in him; usually they are handed back at once, but this Indian kept them, and I began to wish I had not been so particular, and I missed my good friend, as I call my pistol, sorely that night, though I didn't have any occasion to use it; yet there is something companionable about a pistol, and I would have slept more soundly if it had been by my side.

The following day the men continued resting, but in the afternoon I was delighted to see them making preparations to start the next morning. 


\section{A NDACROSS PANAMA}

A little later I threw the town into a state of excitement because of some paper pinwheels that I made to amuse the children. The men wanted them at once, and I used up numerous pins and nearly all my paper before they were satisfied. When all were supplied, it was an amusing sight as these fully-grown men pranced and ran about among the houses, shouting and kicking up their heels like a lot of children; the women following around after them equally delighted, and full of excitement. The fun lasted for about an hour, and then the pinwheels were worn out, and the village settled down again.

The next morning the chief said they were ready to go on, but to my surprise and alarm I found that five men were to be my companions, and that the women were not going at all. There was no help for it, now; to return was impossible, and if they intended to murder me I could not escape them by going back; so I made the best of the situation and we started. The men made good progress, and about noon we reached a little Indian village called Po. Here my chief and the chief of Po sat down to have a talk together. 
After a time the chief of Po said to my chief, "Well, are you going to kill this one?" To which my chief replied, "I don't know, yet; I must get him up in the woods first and see if he has any money, and besides, the trader takes care of him and perhaps he will only die in the woods." I could understand some words of their language, but they fell to talking about other things, which I could not understand, and I went to sit alone and consider my prospects. It did not seem very encouraging, but the road led on, not back.

We soon were under way again, following the river as it wound ever on up, and still up among the mountains.

Sometimes the rapids were really dangerous, and it was wonderful to see the way in which those Indians managed the shallow dugout or pit pan, as they called it. One stood in front with a long pole to keep it off the rocks, two paddled, one bailed the water out, and one stood behind, steering with a long pole. When we came to a rapid they would shout to me to sit still, which was all I could do; I was so frightened I scarcely dared to breath, while those men, shouting with excitement, made their way along 


\section{AND ACROSS PANAMA}

the sides of rapids which to me seemed impassable.

At times we would come to long stretches of quiet water, and then to other rapids, and so on up and up, the men shooting iguanas and catching turtles and fish as we went.

Iguana is said to be very fine eating, but after a time I could not bear the sight of it, though it seemed good at first. There was plenty of turtle at all times, however, and so I got along very well.

It was strange to see the Indians catch turtles and fish. A turtle would slip off a log into the water, and at the same time an Indian would dive lightly from the boat, and it was rarely indeed that they missed them. A certain Indian named Wee Wee was particularly expert, and if he saw a frightened fish hide itself as we passed on up the river, he would slip quietly over the side of the canoe, and nearly always succeeded in catching it.

At one part of the journey we found ourselves in a deep ravine, which was so high up among the mountains that we could look back out of it over a great stretch of country and lower mountains, and as we sat in the cool shade

69 
of the cañon, where the water was still and deep, and where the rocks were all covered with orchids, ferns, and mosses, it seemed, looking out over the distant country, as if something was about to overwhelm us or that we were soon to be swept over a cataract, it was all so strange and unearthly.

One morning, after sleeping by the river bank, I noticed two little red spots on my arm, considerably above the elbow; at times they were very painful, and after a day or two became almost unbearable and had grown quite large. I tried to press them out, thinking they were boils, and that the sun made them hurt so severely. I was sure something was in there, so, getting a bunch of flesh up between my fingers, I pressed with considerable force, and to my astonishment a white, threadlike worm began to appear, and as I pressed harder a large grub popped out and fell in my hand. It looked like a bottle with a long neck tapering to a thread, and had black hair at the folds of its skin. Then I took another out of the smaller sore, and thought I would have no more trouble with them; but in this I was mistaken, and my arm began to swell rapidly, aching miserably, while 


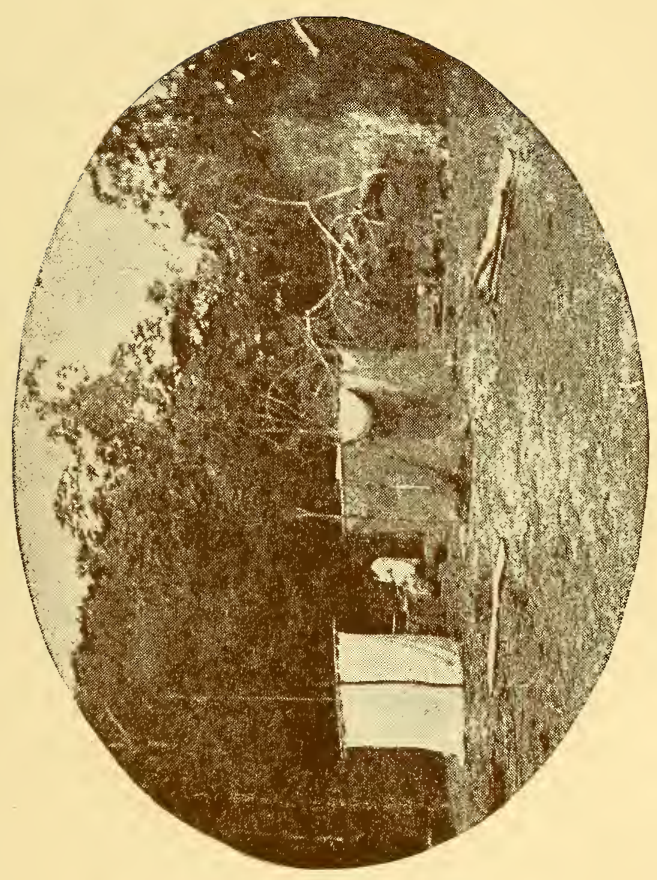





\section{A NDACROSS PANAMA}

green matter collected in the openings left where the grubs had been. After a time these conditions became so alarming that I showed my arm to the chief, who said it was very bad, that it was the mosquito grub, and that I should have told him sooner. Then he went to the woods and brought back a root, which he masticated with some chewing tobacco, and placed the mass in the sores, after which they healed with what I thought unusual rapidity. I am told that I made a lucky escape, as the sores following the expulsion of these grubs are at times dangerous; rarely so, however, if taken out while they are yet small, and only those who are ignorant in respect to them suffer any damage.

It is said that a long black mosquito lays the eggs that produce these grubs; how, nobody has any idea, and at times they are very annoying. After that experience $I$ was careful to sleep under my mosquito bar, and have been careful to do so ever since while travelling in the tropics.

After we had gone a short distance further, the Indians stopped, saying that we had reached the limit of canoe navigation, and must now make our way across the mountains on foot. 
Our things were soon landed, the canoe drawn well up on the bank, and then the men said they would have to rest for three days. Here was more trouble. We had been unusually slow ascending the river, we had rested a day and a half at Wampoo, and I had lost three weeks at Gualpatante. With such progress as this it seemed only reasonable to expect that my rival would gain the victory and destroy the company's titles before I could succeed in having them registered.

I was anxious enough, and tried every possible means to start the men on, but it was of no use, and we lost the balance of that day, and there seemed no prospect of moving for all the week.

Next morning I tried again, and offered to throw away a lot of my things and make their packs lighter, but it was of no avail. Then I thought of a bottle of brandy in one of my cases, and offered it to them for the evening if they would go on.

This suited their fancy. They will do anything for whiskey or brandy, and arrangements were soon made. I threw away a lot of my things, and gave a woollen shirt to one of the 


\section{A N D A ROSS PANAMA}

young men, who was really sick from cold and exposure, and I threw away all the things in his pack, so he had nothing to carry. Among my clothes was a canvas hunting-coat, having the usual brass buttons with animals' heads. The chief took a great fancy to it, saying, "Give me this," a number of times. I was not well pleased, and told him I would see him further first, yet he took such a fancy to it, going back time after time to look at it, all the while regarding me with glittering, envious eyes, that I thought if this man would murder to secure forty dollars from a person who trusted him as guide, he would probably do as much to secure the coat that he fancied so avariciously, consequently I gave it to him, and then all were contented.

It was a pity to throw away so many useful things, but regrets were unavailing, so shouldering my rifle, which $I$ had been told never to trust out of my hands, we started, the chief leading the way.

At first the trail was easy, and I began to think that reports were exaggerated, but presently we came to a stream that must be forded. I started to undress, as it was deep, but the 73 


\section{AROUND THE CARIBBEAN}

chief said, "No use; can't stop; must walk river," which was literally true. We had to scramble along its rough banks, in and out of the water, make thirty-three deep fordings and climb up and down all sorts of places.

The novelty kept up my enthusiasm, but about the middle of the day I became very tired, and once slipped over quite a precipice, and would have fallen headlong if one of the young men, who was just below me, had not caught me in his arms. I fell right into them, and though I am pretty heavy, his strength did not yield to my weight. It seemed as if I had fallen against a well-braced pair of posts, and then the way he lifted me to a safe place, as though I weighed nothing, made me regard him with unusual respect, and there was something about the care with which he handled me that made me feel much more secure with these wild men.

After struggling on for a short distance, we fell in with a number of wild hogs. I was too tired to shoot, but, telling the chief how to use the sights, I handed him my rifle, knowing that in the excitement of the moment he would think only of the wild hogs. He took careful aim, and to my surprise his first shot with a rifle was 


\section{A NDACROSS PANAMA}

a success, and we had a large wild hog that would give plenty of meat. We now pushed on higher up among the mountains, and finally made camp in a grove of giant mahoganytrees.

The men built a rancho of broad vijao leaves, and then asked about the whiskey I had promised them. I told them we would have it as soon as I put on some dry clothes.

Then they went to work preparing the pig, and presently I called them to me, holding up a bottle covered with a neat straw case, so that they could all see it. They came at once crowding around me, and I stood there holding the bottle, still covered with its straw case. It was a scene that I will never forget, and even now I can fancy, almost, that their wild, excited faces are pressing close about me. It was a repulsive sight, with the cords of their necks rigid, their bloody hands clutching their great knives, their eyes protruding, indicating the intense strain of beastly anticipation; the Indians stood with their whole beings rooted hungrily on that covered bottle.

I held it up for an instant, and then with a 


\section{AROUND THE CARIBBEAN}

flourish drew off the straw case - and found that the bottle was empty.

The dark rage of disappointment that came over those faces sent my frightened wits to the winds. For an instant my life was not worth a cry to save it, nor could I realize what was happening. In his rage, the chief standing next me raised his knife, but, as he was bringing it down on me, the instinct of self-preservation caused me to start back, and to accuse the man at my side of stealing the whiskey; then the knife that was intended for me was turned and thrust at him, and but for my interposing my hand he would have been killed. He had carried the pack containing the whiskey, and now the maddened Indians turned on him, giving no heed to his protests; he had carried the whiskey, and it was gone. His face changed with fright to a brownish gray, and then, my wits coming back, I threw myself between him and the threatening knives. Now I saw what had happened; the top of the bottle was broken, and I led the men over to my pack; they followed, probably expecting a fresh bottle. Then I showed them my clothes soaked with brandy, 


\section{A NDACROSS PANAMA}

and their rage turned to despair; they almost wept, and the five sat on a log together, a pitiful sight in their disappointment.

Taking advantage of the lull in the storm, I promised them that, on reaching the settlements, they should have as fine a drunk as the law would allow. They were quieted at this promise, and with a sort of mournful acquiescence went dejectedly to work again preparing the pig and getting dinner. We had roast pig and a kind of biscuit that they made out of flour, salt, and water; the dough rolled up in thin strips, protected by leaves, and roasted over the fire.

The dinner was good, and we ate nearly the whole of that pig and all the biscuit. I was soon ready for bed, and on turning in took the precaution of getting under my mosquito-net and keeping my pistol in my hand.

The men were holding a consultation together in subdued voices, but I did not notice this, and presently they all went to bed. I fell asleep holding my pistol in my hand, and I can remember indistinctly that a torch was held near the net so as to light up the inside for a time, 


\section{AROUND THE CARIBBEAN}

and, half-awakened, I seemed to see ugly faces peering through at me. Perhaps they saw the pistol, and so kept off, but it might have been that I was only dreaming. 


\section{A NDACROSS PANAMA}

\section{CHAPTER $\mathrm{X}$.}

\section{TREACHERY AND POISON}

WE did not make a very early start next morning, and the men were slow getting breakfast, but at last it was brought to me, biscuit and some tinned meat, with a choice piece of wild pig, apparently saved especially for my benefit. I ate heartily, and then we started on, the trail now leading us up a steep mountain.

Presently I began to feel sick, and then to grow dizzy, and after a time could only struggle along. The chief saw it, was indifferent, and went on; then two other men followed him, and the two younger men, who were a little behind, came up and were passing on with the others. Apparently they were all leaving me alone in the woods. I ordered the two young men to stop, but they would not. I made a 


\section{AROUND THE CARIBBEAN}

motion with my hand, reaching for my pistol. This checked them, and we all sat down. Then I sent one of them for water, which he was a long time bringing, and after drinking a quantity I felt better. I do not think they intended to kill me with poison, but only gave me something that would make me sick, and then it would be an easy thing to let me lose my way.

I rested awhile, and, having drunk a quantity of water, was ready to go on again. After a time we overtook the others sitting by the roadside, and the boys got a fine blowing up from the chief in words which I could not understand. I made poor progress that day, and it was hard work to keep up at all. We fell in with a flock of wild turkeys; I handed my rifle to the chief, and he killed an unusually large one, which gave us plenty of fresh meat again. We did not go much farther, and at night made camp in a beautiful ravine among the mountains, where there was a stream so cold that I could scarcely bathe in it. On one side was a high precipice, and a sloping mountain on the other, with a little open place of fresh, green grass by the stream. It was an enchanting place, and I began to feel better at once. 


\section{A NDACROSS PANAMA}

Keeping my pistol ready at my side, I took no special notice of the Indians. They were holding a whispered conversation, and after a time seemed to agree on some point, and began preparing the camp for the night. Presently the chief came to me, and said in Spanish: "A bad place for tigers [jaguars] here; two men have been eaten, and we are afraid."

"Never mind," I said, "I have my rifle and pistol, and will kill them if they come."

"But you are under your mosquito-net and in no danger." Which was true; a jaguar, or tiger, as they call them, will walk around a mosquito bar all night, often forming a beaten track about it, but it has never been known to make an attack. "Yes," the chief continued, "for you no danger, but for us, we have no guns; give me your rifle and I will take good care of you."

Not wishing to refuse at once, I said he could have it when I went to bed, and with a look of triumph and delight he went back to tell the others.

Here was a predicament, and I began to consider earnestly how I was to get out of it. The Indians were now in another mysterious consul81 


\section{AROU N D THE CARIB BEA N}

tation, and presently they came to me, and the chief said, "The tigers are so bad here we are af raid with only the rifle; give this man your pistol, and we will sleep each side of you and keep you very safe; no harm will come, not anything."

I replied, "When I go to bed you can have it." They were delighted, and went off together, but they soon came back, asking if I had anything else that would shoot. On being told that I had not, they asked if I would not let them have my big knife, because the tigers were so dangerous, and they would be afraid even with the pistol and the rifle. Evidently the plan was to disarm me entirely, and I told them to wait till I went to bed, and they could then have what they wanted. I kept my firearms carefully in my hand, and was glad to find that they did not demand them at once, and so I remained, considering.

The men were now in high spirits, and went to work getting supper, and making up a very comfortable bed for me.

As soon as the turkey was ready, they all sat around, picking out choice pieces for me, and urging me to eat all that I could. Then they 


\section{A NDACROSS PANAMA}

had their supper, and after that went down to the stream to clean up the dishes, chattering like a lot of children. The mosquito-net was hanging conveniently, and lifting up one corner, I slipped my rifle, pistol, and hunting-knife under it, crawled in myself, and with my pistol in my hand sat up waiting for developments.

I could see out very well, but, as the net was made of unbleached muslin, no one could tell exactly where I was, and, if there should be any attempt to cut through at me, I could shoot before the knife could find me out. The Indians seemed to know this. When they came back, they walked around the net, talked, considered, and finally gave it up, and each one went to bed. Then I felt relieved and was soon asleep, well assured that I was perfectly safe till the morning.

I was up early, and met a rather ugly crowd of Indians. No breakfast was prepared, and I had to get along with the remains of the turkey and some crackers. The men said very little, but shouldered their packs, and marched off, I following them. We had not gone far when the men put down their packs by a brook, and stood talking together; their faces indicated trouble, 83 


\section{AROUND THE CARIBBEAN}

and I thought to myself, "Now it is really coming." I took little notice of them, however, and pretended to be examining some rocks, and presently pretending that I was deeply interested, I climbed up on one, which kept me well out of the way of their knives. The men stood and watched me for awhile, and then the chief came to the rock, and looking up at me said:

"We have been considering. You have given one of us a shirt, and that is good; and you have given one of us a coat, and that is very good; but now the three other boys are so discouraged they can't get over this high mountain unless you take out your money and give them each another dollar."

I replied that I was sorry, but I had no money; that the trader had paid them for me, as they knew, and then I went on examining the rock, I am sure not with great attention, except in appearance, because $I$ have never been able to remember what kind of rock it was.

"We can't go on unless we see the money." "Very well," I replied, "stay here. I have no money."

Then the chief went back to the men, and they talked awhile longer. Then he came back 


\section{A NDACROSS PANAMA}

again and said: "But you must have money. All Americans have money; only Indians are poor. The boys can't go on unless you show them your money and give them each another dollar."

"I have money," I said, "but not here; I must go to bring it, and you must take good care of me when I come back, because $I$ will have a thousand dollars with me; more than you ever saw before, and I will sleep at your house so that you can take good care of me."

He opened his eyes and went back, and they talked some more. Then he came again, and was a little more threatening in his appearance: "We know you have got money," he said, "and we want to see it, and the boys won't go on."

"I have only a little," I said, showing a few loose dollars that I carried in my pocket; "but I will do this. When we get to the settlements, let the people know that I have very little money, and that they must take me on cheap; then, if I have any money left, I will give each of the boys another dollar." $\mathrm{He}$ went back, and in a few moments came to me again and said: "It is this way: we are thinking of the drink you promised us; perhaps we can go on. 


\section{AROUND THE CARIBBEAN}

Will you surely give it to us?" and there was an anxious look in his face.

"Yes," I said, " you can depend on it."

"All we want?"

"Yes, all you want."

"But we can drink a lot."

"Never mind, go on; you shall have it."

"Señor," said the chief, "that will cost a lot of money. You have got money; we want to see it," and an ugly look came in his face, while the men crowded up to the rock. They certainly had me, but they saw that my pistol was ready, and I sat there facing them. Suddenly a thought came to me, and I said, hastily, "I have credit. I can get all the things I want; you shall have the rum, even though $I$ have no money here to pay for it." Then I showed the chief my wallet, with passport, and some documents with big seals on them. He looked at it and said: "This credit?"

"Yes, but only when I sign the bill."

They traded on credit themselves, and after a moment the chief said: "He hasn't any money; let's go on."

"But he has lots of things," said one of the young men, looking at the packs. 


\section{A N D A ROSS PANAMA}

I heard nothing more, and presently they took up their packs and marched on.

I had no more trouble with them for two or three days, but one morning we came to a Piyú village, and the men said that they must stop there for the night. I protested, and said I would not, that they must go on; but it was of no use, and my men went off with the Piyú men, and all talked together at the edge of the jungle.

I felt miserably. My men were evidently unwilling to kill me themselves, because they feared my friend the trader; but if the Piyú men killed me, that was a different thing.

The wife of the chief in that village was part Spanish, and I began to talk to her, and presently asked if I was to be her guest. She replied that she supposed so.

"But will I be safe here to-night?" She made no answer.

"Had I better go on to the settlements?" "Yes," she said, "you had better go on; there is plenty of time."

"But the men won't go."

"Make them," she said.

I went out, and angrily commanded the men 87 


\section{A ROU N D THE CARIB BEA N}

to go on, but they would not even answer me. Here was fresh trouble - to get all through the wilderness on my wits and then to be killed by these miserable Piyú men. I was turning over various plans, and presently went back to the house and saw the woman again, and said to her, "The men won't go. Will I be safe here tonight?"

She made no answer.

"Am I your guest?"

"Yes."

"And will any harm come to a guest in your house?"

She looked away.

"A guest, and not safe in your house?" I protested.

She looked at me and then at my pistol. "Can you shoot?" she asked. "Then do this: hang your hammock across that corner; I will bring my mats and sleep just outside it. If I touch your foot in the night, be ready and shoot quickly."

We fixed the things, and then she said: "Now, you will be safe." She was evidently a determined woman. The Piyú chief objected to the arrangements, but that is all the good 


\section{AND ACROSS PANAMA}

it did him, and when night came I was soon asleep, and had a thoroughly good night's rest. Next morning, grateful to my good hostess, I started on and reached Coulmé, the chief city of the civilized Piyú Indians, about three in the afternoon.

It was a great relief. I had now reached the settlements and was on the main road to the capital, which I could reasonably hope to reach in three or four days. At Coulmé the civilized Piyú men did everything for me, so soon as they found I had not come from an infected district, and all they had was at my disposition. The chief of their village called a council, and he and the alcalde examined my papers, and, with all the men of the place crowding about, made polite speeches of welcome.

My men said I had no money as they had promised, and the alcalde asked me about it; but I said I had plenty, and a tired look came over the faces of my guides. They could not get any rum, because there was none to be had, but I was safe now, and did not care. I gave them each the extra dollar; they seemed to be content, and that was the last I ever saw of them. I have travelled very far since then, 


\section{AROUND THE CARIBBEAN}

but I have never had guides that were so difficult to manage.

Urged by the necessity of my mission, I asked the Piyú Indians to send me on at once, though I would have gladly remained a few days with them. Two sturdy little men shouldered all my things, and in a short time delivered me safely to the regular authorities at the nearest Spanish town. Here arrangements were made for sending me to the capital. Nothing had been heard of my opponent, and I began to feel secure.

Without waiting for breakfast, I started on next morning, riding a stout mule, a young Spanish-American peon for my attendant, and every prospect of reaching the end of my journey without further trouble. I had expected to buy something to eat on the road, but had not succeeded very well, which was inconvenient. About noon we came to a broad, circular depression in the valley, surrounded by green grass-grown hills that looked like great waves just ready to break and sweep all before them; beyond were the mountains, looming up with startling effect, distant, yet seeming to hang, as it were, just over those picturesque green 


\section{ANDACROSS PANAMA}

hills, like clouds hanging over the waves of the ocean. As we crossed this strange place, I noticed what appeared to be fine mushrooms growing abundantly, and asked my guide what they were.

"Fruit of the earth," he replied.

"Are they good to eat?" I asked, feeling decidedly hungry.

"Yes," he said, after a moment's hesitation, and then added, eagerly, "Shall I get some for you?"

"Yes, I would like to try them."

He brought two almost as large as dessert plates, and then rode on with one in his hand. By all appearances they were the finest of mushrooms. I tasted cautiously, and then ate one and part of another; but just then I noticed that my man was not eating his, and I thought to myself, "Now you have been a fool." But on waiting a moment, and not feeling any ill effects except a sort of acid coppery taste in the mouth, I did not take any action, and rode on, my man watching me intently. It was an extremely hot day, and some hours later, at about three P. M., while riding across a treeless plain, my stomach suddenly felt as if some one 91 


\section{AROUND THE CARIBBEAN}

had stuck a knife into it, and then had poured hot oil in after the knife. I struggled to the ground, and by tickling the palate caused a period of vomiting, and relieved my stomach of a quantity of hard yellow matter, though I had eaten very little. For a moment or two I felt better, and then the pains came on again, and the burning, which now extended all up my throat and to my nose and mouth, was almost unendurable. I threw myself down in the shade and asked my man to get me water. He looked at me indifferently and said, "There is none nearer than a mile, and $I$ have nothing to carry it in."

The pain increased, and still he sat watching, making no effort to help me. Now the burning had extended to all my body, my mouth seemed perfectly dry, and a sort of delirium was ever increasing in my brain, till, almost beside myself with pain, I got on my feet, clutched the mane of my mule, and guided him on, seeking the river, though it was some distance before me. I had taken only a few steps when further progress became impossible; I could scarcely see, and had lost all control over my legs. If anything was to be done, it must be quickly. I 


\section{AND ACROSS PANAMA}

had all sorts of remedies for fevers and sickness, but had never thought of being poisoned. Suddenly I remembered a can of vaseline in my saddle-bags. I got it out I don't know how; the day was so hot it had turned to oil, but anything to drink would have been acceptable, and so I swallowed a quantity of the liquid vaseline. I will never forget the sensation of that swallowing; it seemed to touch every point in my burning throat and stomach, and to set them at rest. I saw again, and my first thought was for water. By keeping one hand on my mule I staggered on, followed by my indifferent peon, and just as the pains were coming on again $I$ reached the river and fell to drinking water, and when I could drink no more I thrust my arms deep into the cool stream, and the very pores of the skin seemed to lick up the water. At intervals I would drink all I could, stopping only when it was physically impossible to take more; yet in two or three minutes $I$ would be drinking again as eagerly as ever. Where the water went to I have no idea; it seems as though the human body could not hold the amount I drank.

After a time there came a lull in the pain, and the desire for water left me, and then there 93 


\section{AROUND THE CARIBBEAN}

was a delicious sensation of languor and rest all over my body. I lay there exhausted, and feeling a numbness and chill come over me, I believed that I was dying, and did not care. Then thoughts of my defeated mission, the triumph of my rival, the grief at my home far away in the North; all came vividly to my mind, and I determined that I would not die. I staggered to my feet, mounted after several attempts and started on a wild ride for help to the little city of El Real, about three miles away. As I went I made the mule jounce and shake me on the saddle, which seemed to keep up the circulation. As I drew near the city I got a little boy, whom I overtook, to run ahead and buy some raw eggs. Presently he met me with them, and the whites of these gave considerable relief. Then I got a big gourd of water; there must have been about three quarts. It had a sweetish taste, but $I$ drank it all, and in an instant I was vomiting with almost incredible violence, and was nearly suffocated by it. I relieved myself of more of the hard yellow matter and quantities of water, and was thoroughly satisfied that there was nothing more in my stomach. My servant now became all attention, 


\section{A NDACROSS PANAMA}

took me to a good house and did for me everything that was possible. After resting a short time I took some rum and black coffee, went to bed and fell into a sort of stupor, in which I knew nothing, but was dimly conscious that at intervals all through the night my man came and rubbed my arms and legs vigorously.

The next morning I was better, and rode on to Jutigalpa, the capital of the Department of Olancho, the point toward which I had been struggling so long.

I inquired anxiously for my rival; nothing had been heard of him. I had arrived first.

Without losing any time, I went to the government offices and registered my titles, and then drew a long breath. My rival could come as soon as he wished; the registry was complete. 


\section{AROUND THE CARIBBEAN}

\section{CHAPTER XI.}

PERPLEXITIES AND SPANISH - AMERICAN HOSPITALITY

Next day my first care was to arrange for an expedition down the river with sufficient equipment to relieve my companions and bring up all our things. I went to a merchant on whom I had letters of credit, to be sure that funds were available, and, on being assured that money was there at my disposal, felt that I could safely send after my companions, and started the expedition at once. Then I rented a small house, hotels being unknown in Jutigalpa, and made myself comfortable.

I was far from the beaten track in a quaint old Spanish-American city, the principal place in the great interior valley of the Olancho; a region shut in by lofty mountain ranges, isolated, almost, from the outer world. Shortly 


\section{A ND ACROSS PANAMA}

I found myself in need of more money, having reduced my funds to two dollars and fifty cents, and went to the merchant on whom my letters of credit were drawn.

He was quite ready to supply funds, but when I presented a draft, he said: "There is some mistake here, my instructions are that your superintendent must countersign all drafts."

"No," I said, "I deposited the n. sney personally, and the credit is secured against my own deposit." Explanations were of no avail, however, some mistake had been made; I could have no money, was alone in a strange city with only two dollars and fifty cents between myself and starvation, the mail comunications uncertain, and no possibility that a letter could reach New York under six weeks. Here was a difficulty, and, to make matters more complicated, a polite constable came that afternoon to arrest me because of some matters relating to unpaid debts contracted some years earlier by my superintendent. The prospect was not altogether charming, but, remembering that if I were arrested they would at least have to feed me, a consideration I was not in a position to despise, I submitted willingly; and then the constable 97 


\section{AROUND THE CARIB BEAN}

decided that he would not arrest me, went his way, and left me to wonder why he had come and what I should do. Fortunately, I had paid for my house in advance, so I was sure of a place in which to sleep, and, as bananas were three for a cent, I would not starve; but the diet was not the most exhilarating. I lived on bananas for three days, kept my own counsel and waited. I was an object of curiosity, the boys of the town wandered in and out of my house at will, and all the fruit venders came to offer me bananas. The third day, in the afternoon, I was delighted to receive a visit from a gentleman who spoke perfect English, and who inquired minutely about my affairs.

With many apologies he assured me that I was most welcome to their city, and that he hoped I understood their difficulty in accepting drafts from strangers, in fact, almost every American who had visited their city had sold drafts which on being presented had proved worthless; and so, with many profuse apologies, he protested it was not lack of hospitality, but only that they had lost so frequently. I assured him I understood, and did not expect any one to take an unsecured draft. Still he protested, 


\section{A N D A C R OSS. PANAMA}

apologizing and regretting my three days' inconvenience, and finally ended by saying that he had been selling cattle, and, having a balance of three thousand dollars on hand, begged that I would accept it until my funds arrived, and hoped that I would excuse his neglect in not offering sooner. This was indeed Spanish hospitality, and I told him if he would lend me enough money to cable home, my funds would arrive immediately. We went to the telegraph office without delay, and next morning a reply came, bringing ample funds, my credit was established, and every door was opened wide for me.

To become a part of the daily life in a remote Spanish-American city was a charming experience, and I have the most pleasant recollections of my brief visit to Jutigalpa; so pleasant indeed that $I$ am often planning to return. There is a legend of an enchantment pertaining to a group of rocks overhanging a deep pool in the Olancho River, and it is related that whoever dives from those rocks to the deep, clear water below them must return to Olancho, and die there; though the venturesome person who dares the enchantment may wander far over the 99 


\section{AROUND THE CARIB BEAN}

face of the earth, and return to and leave the valley many times, yet in the end he will die in Olancho. Each morning a goodly company of men and boys would visit the deep pool for a bath; it was the regular morning exercise, and I rarely failed to find a place in the party. I am not a believer in charms, and have taken a header from that enchanted ledge of rocks many times. Since then I have wandered very far, yet I have never found a place so beautiful as the valley of the Olancho, and some day I hope to return to it once again.

After our bath we would go back to the city for breakfast, and then the morning's work would be taken up, and by noon-time much would have been accomplished. Then came the dreamy rest through the heat of the day, when one simply sat at ease and did not care even to think. Usually some friends would come to my house, and pleasant hours were spent smoking, idling, and discussing affairs of local interest; then in the afternoon work again, and at evening a walk about the city, visiting friends or stopping to talk with young ladies seated in their low, open, but heavily guarded windows.

One beautiful moonlight night, as I strolled 


\section{AND ACROSS PANAMA}

about alone, I passed the shop of a humble shoemaker, who was seated before his door. As I passed he politely invited me to a seat; such an invitation did seem a little strange from my shoemaker, yet, not wishing to appear rude, I accepted his invitation, and found him well informed about the valley and its history. Presently the Governor of Olancho came passing by, and the shoemaker invited him to a seat, which he accepted at once; then a Senator for the district, and one of the richest men in the city, came that way, and he, too, took a seat at the shoemaker's door. Surely we were a mixed company, yet no differences were made; a shoemaker, a stranger who had come among them, one of the city's richest men, and the Governor of the Province, all on a pleasant footing together, without any pretension; yet the shoemaker never failed in due respect, nor was there anything in his manner from which one might infer that he did not think himself good enough to pay his respects where respect was due.

Among such surroundings the days went pleasantly, and my brief rest was thoroughly enjoyed. It was in the month of December, the time of festivities, and there were bull-fights,

101 


\section{A ROUND THE CARIB BEA N}

parades, and on Christmas Eve dances and family reunions; to all of which I was invited, and I have never had the pleasure of more kindly entertainment. The principal reunion was given by Governor Zalaya's family, and there all the best people of the city were gathered together. Etiquette was somewhat different from our customs. The company was invited at eight o'clock in the evening, and it was polite to arrive on the minute. Guests did not go directly to the house, but as the hour approached stood near, and when the great clock in the church chimed eight we all filed in together, and were received by our host and hostess; then the gentlemen went to one room, the ladies to another, and the sounds of pleasant conversation filled the house. Everywhere were preparations for merrymaking; at the doors and in the yard servants, peons, and estate tenants were gathered, enjoying themselves at the expense of their masters, and a great company they all made; but within the house were only the guests, not so very many, merely the family and their most particular friends. A good time, a period of thorough enjoyment, has an effect on one's spirits, and all this scene 


\section{A NDACROSS PANAMA}

was most exhilarating. After we had talked together for awhile, a lively polka was started, and the ladies came from their room in single file and stood with their backs to the wall in the main saloon, and then the men filed out of their room and stood looking on. The young ladies were pretty, modest, and becomingly dressed; some of the jewels were truly magnificent. I was told later that many of them had been handed down from generation to generation since the days of the Spanish conquest.

A friend whispered to me that I should not seek a partner at once, that there were more men than ladies, and it would be polite for the men to give place to each other; so after a moment of forbearance, and mutual urgings among the gentlemen, a dance was arranged, and to measured music now grown slower we danced about the great saloon, while the servants, peons, and their friends stood looking in at the door. I was dancing with a charming little Señorita, but found myself no match among my SpanishAmerican friends, who were going through a series of graceful figures and a great variety of steps, a sort of quadrille-polka and stately ceremony combined. I could take no part in 103 


\section{A ROUND THE CARIB BEA N}

this, so devoted myself to my partner, and found the dance very pleasant. When it was over, I took her to a comfortable seat in the great saloon, and, drawing a smaller chair to her side, sat in it myself, expecting a pleasant conversation till the next dance; but she simply gave me an appealing look, and said nothing. Then I noticed my hostess standing near the ladies' room as if petrified with dismay, a look of horror on her face, while all the young ladies were staring as if their eyes would pop out.

There was an instant of bewildered looks, then the Señorita's Duenna came anxiously to the rescue, and hurried her to safety in the ladies' room, but as she went she looked back at me with a merry laugh, and I knew the Señorita had enjoyed the adventure. Then some of the men told me that I had committed the greatest indecorum, that no man could sit by a young lady under any circumstances. That I was a stranger was sufficient explanation, and when I told my hostess of our customs at home during a dance, she was deeply interested, and I was entirely forgiven.

We danced till midnight and then went to 


\section{A NDACROSS PANAMA}

mass, a beautiful custom and ceremony; the church was filled to overflowing, all the dancers and merrymakers in the city having come, remembering their religious duties as the first act of Christmas morning. Then each party went again to their festivities, and we who were the Governor's guests returned to a bountiful supper, where there were many different kinds of meats and rich dishes, but very little in the way of sweets. The ladies all sat at a long table, and the men attended them, standing respectfully behind their chairs; then when the ladies had finished, they went back to their room, and the men had supper. After this, dancing was continued till sunrise, the men going about the city, visiting other dances to which they had been invited, and returning to the Governor's dance at pleasure, for after supper everything became quite informal. It was broad daylight when we went home, all agreeing that we had enjoyed a most delightful entertainment; for myself, I have never since attended a dance where thorough enjoyment, friendship, and courtesy were so charmingly blended.

I was fortunate to have been in Jutigalpa during Christmas week, and shall always re105 


\section{AROUND THE CARIBBEAN}

member it as one of the most pleasant experiences in all my travels, yet I was not sorry when the festivities were over and I could take up my work again. 


\section{A NDACROSS PANAMA}

\section{CHAPTER XII.}

EXAMINING A MINE UNDER DIFFICULTIES

Mr first effort was to seek the mines that I had come so far to investigate, and a few days later I left the hospitable city of Jutigalpa, and with a comfortable outfit made my way up the Olancho valley to the valley of Lapaguera, - a place beautiful almost beyond description. The broad valley, level like a prairie, covered with green grass, extended east and west almost as far as the eye could reach; thousands of cattle were quietly feeding, a few trees in groups were seen at places, and on either side, rising abruptly, were great ranges of mountains.

Our trail led over the mountains to the north, and we were presently making our way among groves of tall pine-trees, where from the branches gigantic festoons of gray moss hung 107 


\section{AROUND THE CARIBBEA N}

drooping. As we began to climb the mountains one of our mules commenced a series of unreasonable capers. She was a strong young animal, and evidently preferred the green valley of the Lapaguera to the lonely mountainsides, and she now apparently proposed to rove at her fancy. Sometimes her fancy took her along the high places above the road, sometimes she went down below it, then she seemed to have lost something, and acted as though she expected to find it in the woods, but she had decided objections to walking on the road, and so gave the peons a great deal of trouble. Finally there came to one a brilliant thought. I had a steady old horse, and they caught the ambitious mule and tied her securely to my horse's tail; it wasn't considerate to the horse, but it did fix the mule. She couldn't stop conveniently, and she couldn't get past the horse, neither could she wander up to the hilltops or climb down among the gulleys without taking the horse along, too, but that was inconvenient. For a time all went well, but after awhile we came to a place where the road went down between rather steep banks till it reached a stream of considerable volume. My horse went down the 


\section{ANDACROSS PANAMA}

trail in a resigned sort of way, but the mule started along the bank and wouldn't come into the trail; the result was that presently she could go no further, and then came a tug of war, to see whether the horse in the gully could pull the mule down from the high bank or whether the mule could pull the horse's tail out. I scrambled from the saddle as fast as possible, and then the animals seemed to come to an understanding; the horse backed up as far as he could, and the mule braced her fore feet and hung her head over the bank as far as possible, and so they stood. Presently the peons came and untied them, and I declined to have them done up again; and so for the rest of the way that mule followed its own sweet will, " and a 'mule's' will is the wind's will," and the thoughts of a mule are long, long thoughts, incomprehensibly long.

The trail led on over green rolling mountain ridges and down the little level valleys, and after two days' riding I reached a village called La Union, a beautiful place at the head of a valley of low hills between mountain ranges.

Next morning I made an early start for the mines. I had made a boasting agreement in 109 


\section{AROUND THE CARIBBEAN}

New York that I would examine every portion of the property; reports stated that fabulous wealth lay exposed along a precipice where a stream had cut a deep gorge through the mountains. I found the place just as described, except that there was very little mineral, yet enough to make me anxious to see all the precipice.

I went to the upper part of the gorge, where a good view could be had down the river, but could see no signs of any mineral deposits. Then I said to my guide that we would go on down the river, but he told me it was impossible, that no person had ever been down the gorge, nor could they possibly go. However, we went on as far as we could, and presently came to a place where the river cut its way through solid walls of rock. I then proposed to go around to the other side and come up the gorge, but my guide said that was equally impossible, and that at this place there were about two miles of rock which no man or animal could pass. I quoted the description of the mine, at which the guide laughed, and told me that such a report was the exaggeration of an impossibility. I had no thought of giving up, however, and 


\section{A NDACROSS PANAMA}

asked the guide if I could not swim down the river, at which he looked at me in astonishment. "Impossible; the place is full of snakes, and there must be a big waterfall in there, because the river is much lower on the other side of the mountain."

I wasn't going home without seeing every inch of that gorge; the precipice had been noted in a former report and I proposed to examine it. So I threw off my clothes, telling my guide I intended to take a bath. I found the water cool and pleasant, and presently let the current carry me slowly down, then swam to one side and came back again, as if I meant nothing, fearing that the guide might restrain me by force, for by this time he, too, had entered the water. Then I let the current take me down again. This time I went a little further, and when well beyond his reach, while he shouted to recall me, I let the current carry me into the gorge, then around a bend, and I was alone, rocks and water all about me, and a line of blue sky overhead. I was frightened, but having started, I meant to keep on.

The river was low, and for a time I floated lazily along, watching out for signs of exposed 


\section{AROUND THE CARIBBEAN}

mineral deposits; but there was nothing, only dark rocks of even texture. Presently I noticed that the current was becoming swifter, and so I caught hold of a convenient ledge, and held myself back to see what was ahead of me. There were some rapids, a little cascade, and further on more rapids, and I floated carefully down to them, keeping well against the rocks. There was not much difficulty about getting over the cascade, just a tumble into a deep basin of water, where I was washed up to one side and found a convenient seat on a gravel bed under a rock, where I stopped to rest and consider. The rapids were a little threatening, but I decided to try them, and soon had the pleasure of finding that, though the water was rough, it was deep and easy to swim in, with plenty of eddies along the sides, where $I$ could avoid the heaviest currents. Going on down, I came to a place where the rocks of the precipice suddenly changed, and above the dark, intrusive rocks a contact with sedimentary types could be distinctly seen; but there were no signs of mineral, and I floated on down, and presently came to the end of the gorge, about a mile or more from the place where I had left my clothes. 


\section{AND ACROSS PANAMA}

I rested for a time, and then started to swim back, but it was fatiguing work, and presently the current became too strong for me. Here was a predicament; it was some miles around the base of the mountain to where I left my clothes; to walk that distance naked in all the burning sun could not be even thought of, and to clamber along the rocks where, because of the dry season, hundreds of snakes had gathered, seemed madness. I was well perplexed as to what I should do, and not a little frightened. After considering, I determined to climb along the rocks, and started out on a really perilous journey. I saw snakes from time to time, but these were accommodating, and got out of the way, though I was constantly in dread of the next step. Scorpions and black tarantulas were numerous, and as I climbed along the cliffs among the black rocks I saw poisonous snakes and dreaded insects; with deep shadows about me and here and there a radiant beam of sunlight, I was constantly reminded of Dorés illustrations of the Inferno. Weird and dangerous as it was, I soon became accustomed to it all, and then deeply interested in the strange, wild beauty of my surroundings. When I came to 


\section{AROUND THE CARIB BEAN}

the place where I had noted the sedimentary rocks, I climbed up to them, selected a few small specimens to take back with me, and then tying them in a leaf, with a bit of inner bark from a convenient trumpet-tree, I started on again, carrying the little package with my teeth. So I made my way on, swimming at times and at others climbing along steep rocks. A fall, the sting of a poisonous insect or snake bite would probably be fatal, and I was thoroughly tired out with excitement, as well as from the exertion, when I finally got over the little cascade, forced my way along the side of the swift water above it, and came to the open river with an easy swim ahead of me to reach my clothes. One can rest beautifully in the water, and by the time I reached my guide I was feeling quite rested again. A number of people had gathered there, all supposing I was dead, and they hardly knew what to say when I told them where I had been, and I think that none of them believed me. A searching party had gone around the mountain to look for my body, and at the little town of La Union work had been commenced on my coffin, - a matter of some concern to me because 


\section{A N D A R OSS PANAMA}

I had to pay for it, and coffins are expensive in that country.

After this I set out on my way, returning to Jutigalpa, and on the road had an experience with eniguas, a species of small flea. Probably all who travel in Spanish America will suffer to some extent from these annoying insects. The female fastens herself to any protected place on one's skin, particularly under the toe nails; and then working her way through the outer skin, forms a little nest and lays a multitude of eggs; these increase in size, and gradually develop till numerous little grubs are formed, which immediately begin to feed on the living flesh of the person who is so unfortunate as to harbour them. Then serious results may be expected, the pain is most severe, and not infrequently the loss of one's feet follows, or, perhaps, blood-poisoning sets in, to end in a most miserable death. This, however, is only among those who, from ignorance or other cause, allow the eniguas's eggs to remain under the skin till they develop the living grubs. Fortunately, some days pass before the grubs develop, while an intense itching gives early warning that something is wrong, and to remove 115 


\section{AROUND THE CARIBBEAN}

the eggs is a very simple matter; usually after removing them an unpleasant sore is left, requiring some days to heal. I found a number of sores on my feet looking like little boils with a black spot in the centre of each. I thought they were nothing but boils, and was surprised to find a tough skin covering them, but by pricking this open I cleaned them out rather indifferently, and, finding the pain relieved, thought no more about it. Later my feet began to pain again, presently swelling set in, till one morning I could not put on my shoes, and then I became rather alarmed.

I called one of the natives and learned that eniguas had attacked my feet, that I had allowed some of the eggs to hatch, and that now the grubs were eating into the living flesh, which might cause the loss of both my feet. This was serious, and the remedy they proposed was a thing that the bravest might shrink from. I was told that the only way to save my feet was to let the natives strap me down on a table so that I could not move, while they scraped the sores with bits of glass till they had taken out all the grubs, and they might be obliged to even scrape the bones. 


\section{A N D A ROSS PANAMA}

I consented, of course, but the preparations sent cold perspiration trickling down my back. Fortunately, I was spared the suffering; an old medicine-woman happened to be in camp, who said that if I would give her a dollar she would cure my feet in a day without cutting them. A dollar was no consideration, and she had it at once, though I must confess I doubted her. She seemed to know just what she was about, and went at once to the woods to get some herbs. Within an hour she was back again, carrying a lot of bruised leaves crushed together in one hand. These she roasted over the fire and squeezed a black liquor out of them, which she dropped into the sores on my feet. It seemed as though she was using liquid fire, but the sting was only for an instant; then as soon as the smarting had passed, the pain in my feet became easier. I had a number of other sores on my feet and legs which she treated, and then told me that all would be well in the morning. They certainly were feeling much better, and I was decidedly relieved. She would not take any more money, but ordered me to keep quiet and she would come back to see me next day.

When morning came, I was surpised to find 117 


\section{AROUND THE CARIBBEAN}

that my feet were perfectly cool and natural, that all the swelling had gone down, and that the sores were beginning to heal.

They never gave me any more trouble, and when the medicine-woman came back I determined to learn her secret. It was hard work, and money would not buy it; but finally she consented to tell me because I assured her it would be useful to a great many people.

I found that what she had used was a common weed, called locally Soto Caballo, which grows all over Olancho in Honduras; yet $I$ have never met with it in any other country.

I took samples, but, when later I showed them to doctors and manufacturing chemists, I was met with a smile of incredulity for my story, and informed that the profession was abundantly supplied with antiseptics.

After my feet were better, I went on again, and, reaching Jutigalpa, found that my late companions were determined to continue in their chase after delusive hopes, and believing that I had seen enough of their affairs and aspirations, separated myself from them, and turned my attention to other affairs. I had about determined to leave Honduras when I received an 


\section{A ND ACROSS PANAMA}

offer from a party of "capitalists," who had come to the country for the purpose of developing mining interests, and now wanted me to organize part of their working force. I was reluctant to leave Honduras so soon, and considering their offer advantageous both for myself and my principals, I accepted and went diligently to work on their affairs. 


\section{CHAPTER XIII.}

OVER THE MOUNTAINS ON A RACE AgAINST TIME

I soon found that for reckless extravagance and almost idiotic proceedings this outfit was beyond anything I had ever known. One morning responsibility for transactions of which $I$ knew nothing, and for money which I had never seen, were charged up against my department, and I promptly offered my resignation, feeling well assured that $I$ had seen quite enough of those people. Then there was a row, and finally they complained that my course was dishonourable; that they had spent money to bring me to their camp, and that they had thought I was to be depended on. This touched me in a tender spot, and I agreed to be at their service until they were sufficiently compensated for expenses incurred in my behalf, but I refused absolutely to handle any money for them. 


\section{A NDACROSS PANAMA}

One Sunday morning, shortly after our disagreement, the manager and the capitalists who had come out with him were in a state of excitement; perhaps they were tired of telling each other how great they were, or perhaps they had become angry as to their respective greatness; from where I was I could not tell. Presently one of the servants came hurrying over to me, and asked that I should go immediately to the manager. I went, and was told that he might be able to use me in a little matter that had come up. I made no answer, and presently learned that some important papers had been entirely neglected, and that unless by some means or other these papers could be deposited in the bank at Tagucigalpa, the capital, before sunrise Tuesday morning, serious loss would result, and the proposition was that I should go and deposit the papers on time, a difficult undertaking. I would have to reach Tagucigalpa from the lower Olancho valley before Tuesday morning, over a rough trail of one hundred and twenty miles across two mountain ranges - a trip that usually took from five to seven days. After considering a moment, I said: "If you give me a mule that can do the work, I can sit 


\section{AROUND THE CARIBBEA N}

on its back till we arrive; it is only a question of long hours in the saddle, and the endurance of the mule."

I was assured of a good mule, and knowing that there were several high-priced animals at camp weil able to do the work, I made hurried preparations, anticipating a novel and perhaps pleasant experience. $\mathbf{M y}$ preparations were soon made; a pair of saddle-bags, a change of underclothing, an ounce of quinine, a two-ounce package of condensed soup - that was all.

I hurried over to the offices, where we all waited anxiously for the mule. While waiting I was told that if I succeeded in depositing the papers on time my associates would be amply compensated for having brought me to their camp. About nine o'clock the manager's servant came, bringing a mule - a little animal not half grown, and which had never been ridden before. The men employed about the mines had come to see me start, and when the manager said, proudly: "Now, there is as fine an animal as you could want; it will take you easily in two days," the whole crowd began to laugh derisively, which made him furious.

I said to the capitalist: "Mr. Blank, that 


\section{AND ACROSS PANAMA}

mule can never take me in two days; you must give me one of the better animals."

The manager protested angrily, and the capitalist, now thoroughly anxious, said: " $\mathrm{Oh}$, go, go on. The manager is an expert and knows his business; he says the animal can take you; don't object so much, but do something for us."

I said: "Mr. Blank, that mule can never cross the first range of mountains, but I will get your papers in the bank on time."

Then I mounted the little animal, and had considerable difficulty in getting it to start, but finally it did go, and I was soon out of sight over the hills.

It was a gallant little mule, and took me fifteen miles in three hours, and then it broke down, and not another step could I get out of it. I had expected one day's work from it, and the situation was serious.

It looked as though I was stuck, but fortunately some soldiers came along just then, and I made a bargain with them to have my saddle carried on to the next place where $I$ hoped to secure an animal. I left the little mule at a house near by, and then we started. It was 


\section{AROUND THE CARIBBEAN}

an eighteen-mile tramp, but we got in safely about four o'clock.

I went at once to the Alcalde, and applied for an animal, but here I was in worse luck: the city was in "fiesta," and all the men who were not drunk were trying to become so as fast as possible. Animals? Was that all I wanted? I could have all Honduras, but to-morrow. This would have been too late. Fortunately, I found two men who were not quite so drunk as the others, and I offered to pay them five dollars each if they would walk with me all night and carry my saddle and other things till I could find an animal. They readily agreed, and we started on our hard tramp. Rough work, indeed, but I determined to keep on. About midnight we came to a little tavern, and my men were so tired that they begged me to let them find substitutes, and they would not take any of the money. I told them I had no objections to new men, and said that they might make the best bargain they could and save the difference. They tried from house to house, but it was of no use; none would undertake the journey.

Then I said: "I am sorry, but my necessities require that you carry out your agreement; we 


\section{AND ACROSS PANAMA}

must go on." They went obediently, the law and custom of that country compelling them.

At intervals I let them sleep for twenty minutes, mounting guard myself, then we would push on. I was excited, and made the most fearful exertions. Once we lost the trail, and went some miles out of our way, but by sunrise we had crossed the largest range of mountains. We pushed on, and about 11 A. M. Monday morning I reached Talanga, hardly able to stand. I felt sure of success now. I had made seventy-five miles on foot in nineteen hours, and I was within twelve leagues of my journey's end, requiring only an animal that could do an ordinary day's work. But misfortunes were everywhere; not an animal could be had, and I was too exhausted to think of walking further. However, I felt compelled to do the best I could; so I telegraphed to Major Burke, of New Orleans, to whom I was consigned, telling him the condition I was in, and stating that I would come on as far as I could, and when I gave out I would lie down across the road, and if I was not in by midnight to send a courier out to get the papers, as they must be deposited before sunrise Tuesday morning.

125 


\section{AROUND THE CARIB BEA N}

Then I prepared to push on. As I was about to start, a man came and said he owned a horse which had never been ridden yet, but if I thought I could ride him I could try.

It was a chance, but I determined to risk it, and with a good peon at my side started on again. The horse was a little troublesome at first, but he took to work naturally, and I made good progress.

About four o'clock we came to a group of great orange-trees, loaded down with fruit, and because of my exhaustion I never had anything that tasted so good in my life; the fruit was perfect, and for ten cents I bought more than I could possibly carry.

Everything went well till I came to a little place called Cofradia, four leagues from the capital. I felt that I had almost succeeded when sudden pains shot through my body, followed by a violent chill, and then my legs became paralyzed. I lost all control over myself, and it seemed as though my teeth would rattle out of my head. I managed to get my feet out of the stirrups, and half fell to the ground, then I staggered to a house and sank down by the door. 


\section{A NDACROS PANAMA}

As soon as I found my voice, I asked for some hot water, but was informed that the women had all gone to a dance, and the men did not consider it their business to boil water. I might have died - that was nothing; they would not touch a woman's work.

Then I asked for rum, which fortunately they had, and more fortunate still was the tin of quinine powder in my saddle-bags. I drank some rum and then tried to take some quinine, but my hands were shaking so much that I could not measure it, and I shook out a quantity, almost as much as my hand could hold. I looked at it, and then I thought, well, I am dying anyway, and it may as well be from the quinine as anything; so, without considering, I took it all. It must have been nearly a quarter of an ounce; after that I drank a little more rum, then I waited for a moment, and my strength came back. It seemed to be exactly what I wanted.

It was then about seven o'clock in the evening, and I started on at once, but it was cruel work, and I fell asleep continually on the saddle; and presently the peon began to walk by my side to prevent my falling. This continued for a time, 127 


\section{AROUND THE CARIB BEAN}

and finally, about 11 o'clock, I reached the capital.

I had succeeded; this kept me awake till I arrived at the hotel and delivered the papers to Major Burke, who was sitting up, waiting anxiously for them.

He opened the package, looked at the letters and papers, and then said: "Can you tell me what they mean by this absurdity? I have attended to all these matters." I tried to answer, but could not speak, and the major got me into bed as soon as possible, two men helping me undress. I was asleep long before they put me in bed, and I am told that the best doctor in the capital was called to see me two or three times, and that he said the only thing was to let me sleep, though my condition was very serious. He didn't know about the quantity of quinine I had taken, and while I slept this certainly did me good service, and when I awoke, after sleeping all the next day and the night following, $I$ was as fresh and felt as well as when I started.

I said I was ready to go back to camp at once, but Major Burke told me he proposed that I should rest for a week at least, and said 


\section{AND ACROSS PANAMA}

I must amuse myself as I pleased; or, if I liked, I could do some light work for him.

I chose to do the work, of course, and saw a great deal of the major. He was full of enthusiasm over the development of his different mining interests, and spoke eagerly of the day when he would walk in to New Orleans and pay back certain money which the city officials claimed from him, though they had no right to it; and from day to day he worked enthusiastically on, and I have never known a more considerate employer or a more thorough business man.

At the end of the week I started on my way back to camp, taking five days where I had come in less than two. I expected that now I would find my associates more reasonable; but in this I was mistaken; folly and extravagance were unrestrained, and after a few weeks I went away, very glad that my connection with such an enterprise could be terminated. 


\section{AROUND THE CARIBBEAN}

\section{CHAPTER XIV.}

A ROUGH JOURNEY TO THE COAST

After this experience, I prepared to leave Honduras. It was time now to investigate the rubber forests of Southern Costa Rica and Northern Panama. At Jutigalpa I tarried a few days, exchanging visits of farewell with numerous friends, and then set out for the coast, hoping to find some means of transportation to Costa Rica.

On the way to the coast, I came to a place where all the road had been washed out by unusual rains, and my only way to go on was over a little used trail, well known to be rough and dangerous. I preferred this, however, to turning back, and gave little heed to tales of accidents and death told by my guides.

At first the trail was only rough, not dangerous, but presently we came to a steep mountain- 


\section{A N D A R OS S A NAMA}

side, where a fall would mean destruction. A little further on, the trail became so steep that I determined to walk down and drive the mule ahead of me; but she would not go, and I had to mount and ride before she would undertake it. This was rather a novel ride; the mule could not take a step, it was so slippery; she simply set her feet and slid from one bend in the trail to the next, and then turned carefully, and slid on down; it was coasting on mule-back, interesting, but rather hard on the mule, and when we reached better ground she was so frightened that to manage her was difficult. Further on, the trail became soft, a sticky red clay, in which the mules sank almost to their knees, as they struggled on down the mountain. The trail was very imperfect, only a narrow strip trodden out by passing animals, and the first thing I knew my mule was standing on a small log that had been placed to mend about twelve to fifteen feet of the track where it had broken away. Here two or three animals had been killed, and the mule was hesitating, while the log moved uncertainly. To turn back or dismount was impossible; there was nothing to do but force the animal on over and take the 131 


\section{AROUND THE CARIBBEAN}

chances, so drawing the reins tight and throwing my feet out of the stirrups, that I might have a better chance if we fell, I forced the mule across, though it was a good deal like riding on a tight rope.

By good fortune I got over safely, and when the frightened peon - my guide - found his voice, he said, "I should have told you to dismount before you reached it, but if you can ride like that you had better keep your saddle, it will be safer for you and for the mule, too." So we struggled on down, but the dangers were not over. At a turn where the trail was very steep, I could see the track made in the tall grass where two mules had gone rolling down to destruction. Just at this point my mule seemed to lose control of herself and began to slip toward this fatal spot, and there seemed no way to check her; she tried to pull back, but the soft mud afforded no foothold, and we were just slipping over when she braced her forefeet, and then managed to turn herself, hesitated between falling and going on for an instant, and then we headed on down for the next turn.

So it went, and all the while there was a heavy strain on the crupper of my saddle; finally, 


\section{AND ACROSS PANAMA}

at a critical moment, it broke, the saddle slipped forward, and I found myself hanging over space with nothing but a mule's neck between me and destruction. My first feeling was to jump and try to catch the tall grass as I fell; then I shouted to my peon, who, just a few feet from me, was frightened into uselessness, and he simply stood and looked. I kept hauling on the reins to make the mule keep her head up; she was slipping, and I could feel the bank giving way, as she trampled on it to get a foothold. Far below me I could see a river rushing along, and it seemed only a matter of an instant, but here the path was very narrow, and I found that by reaching back over my head with one hand I could grasp the roots of the grass above me, and so soon as the mule was relieved of my weight she regained the path, and we were both safe.

The peon repaired the crupper and I rode on down, but when I got to the bottom of that mountain the strain and fright had been so great I was absolutely played out, and had to rest for an hour before I could sit on my saddle.

I had now reached the low lands again, and stopped for the night at a group of rude huts. 
I was making a small collection of orchids, and saw what I thought a desirable specimen near the top of a tall tree. I bargained with a bright little Spanish boy, who agreed to climb after the orchid and bring it to me for ten cents. He went up lightly enough, then as he cut the plant from the tree, it suddenly swarmed with black insects. The people who were looking on shouted, "Golgas! golgas!" and called to the boy to come down. He knocked the plant off first, and then slid rapidly down the slender tree to the ground, blood dripping from one hand. As he reached the ground, he said, proudly, "I got it, and only one bit me." $\mathrm{He}$ had a deep cut in the fleshy part of his hand below the thumb, which we bound up carefully, the men explaining to me that the golga is a big ant capable of inflicting such a deep wound that a person could be killed by them in a short time if a number should get under the clothes. Later, when I began to look over the plants, one of these fellows ran up my sleeve and started vigorous work at once. I caught him on the third bite, and I think his jaws must have been red-hot, and were developing rapidly to a white heat by the time I killed him. From my own 


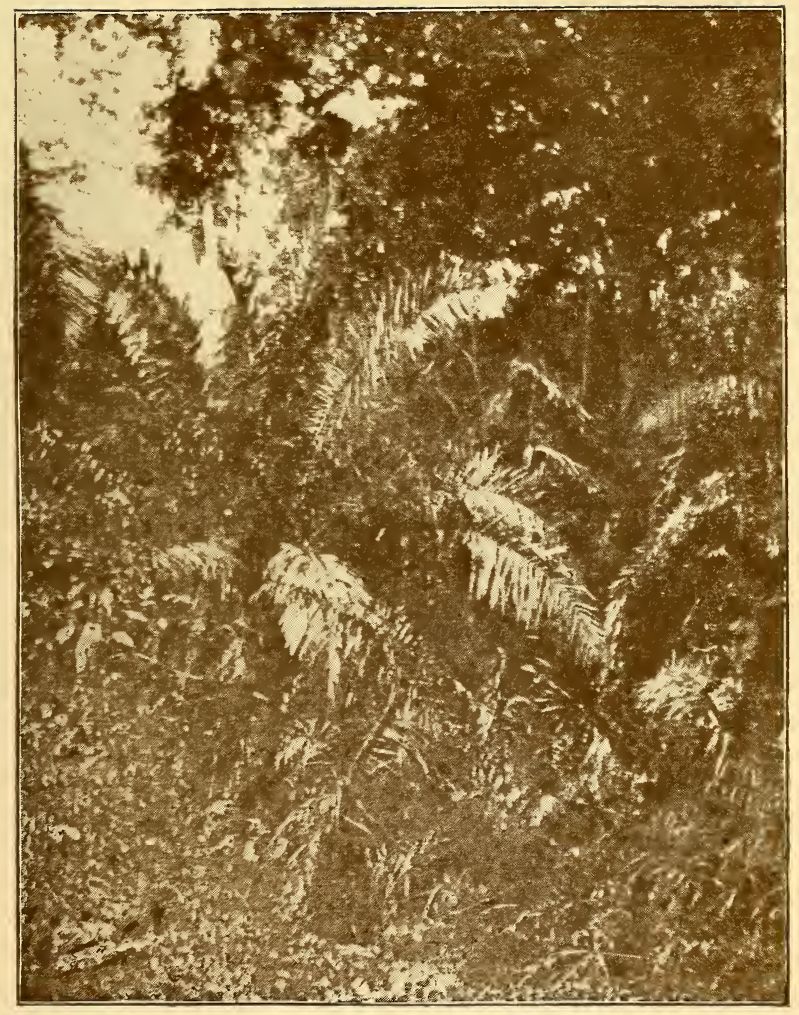





\section{A NDACROSS PANAMA}

experience I shall always feel pretty well satisfied that a number of these ants could do serious damage if they all got at it at once.

On the following day the trail took us through a jungle of giant palms, and, to enjoy the novel scene undisturbed, I left my packanimals and servants, rode on alone for some distance, and then, letting my mule take her course, gave myself up to the enjoyment of the scene. The giant palms of Central America grow from near the ground like great ferns, and rise in graceful curves twenty-five to forty feet. All other vegetation is shut out, and as one passes on great archways of green open in all directions, like the aisles of an enormous cathedral, only these have no end, and blend into one another till they form, in the distance, one solid wall of green, with the long archways leading out to it. In the deep shade of such forests many varieties of ferns and wood flowers grow in profusion. I rode on, lost in wonder, till, suddenly, there came a rustling among the ferns, a moment of silence, a rustling a little before me; and then a large animal stepped cautiously out on the road perhaps one hundred yards or more ahead of me. 


\section{AROUND THE CARIB BEA N}

I could see that it was what the Indians call a black tiger. It looked at me over its shoulders, hesitated for a moment, then faced about suddenly, took a few steps forward, and squatted down in the road, its eyes glowing, and its great tail beating vigorously from side to side. The Indians say if one meets a black tiger, it is kill or be killed, and it is said that if one of these animals appears near an Indian village the people will desert their houses, and that the Indians will never camp for the night where it is supposed the animals are about.

On the other hand, professors of zoology insist that there is no such animal, but as far as I am concerned I think I saw one. It was squatting in the road just in front of me, had a coalblack skin, a thin, loose-jointed body, a rather heavy tail with a tendency to bush toward the end, a square head, small ears, and large, clear, yellow eyes. It looked to me more like a panther than a jaguar, and yet it was too heavy about the shoulders, neck, and head for a panther.

Naturally, I wanted that animal, and there it was, all ready for fight. I drew my pistol, the only firearm I had with me, and tried to 


\section{A NDACROSS PANAMA}

drive the mule nearer, but she didn't appear to like it, and began to act silly. I kept her head on the animal, which was crouching there jerking its tail from side to side with savage vehemence; and from time to time seemed to gather itself as if for a spring, and then settled back again. I was just getting near enough to consider risking a shot, and was trying to quiet the mule, when, suddenly, around the corner my pack-train appeared on a full run, the gold pans clattering, the peons swearing, a tumult generally.

The animal raised its head, looked for an instant, and then with a graceful bound disappeared among the ferns and palm-trees. I was disappointed, but I never did have particular luck in shooting.

A day or two more and I reached the little city of Truxillo again, having travelled over the greater part of Spanish Honduras. 


\section{CHAPTER XV.}

HONDURAS TO COSTA RICA VIA NEW ORLEANS

I AT once began inquiring for a means of transportation to Costa Rica, but, alas, there was none! The Spanish-American republics, though neighbours, are isolated from each other for want of steamships, and in many places the only route of communication is via the United States; and there was now nothing for me to do except take a steamer for New Orleans, and from there return south to Costa Rica.

In this trip there was little worth recording. On the way to New Orleans the gulf was so calm that numerous varieties of marine life could be seen darting about, or floating idly as the steamer made its way among them; but going south again it was rough, and I made a bitter enemy of the steward on the little 


\section{ANDACROSS PANAMA}

steamer by becoming uproariously seasick, and spoiling four breakfasts one morning before I could retain food comfortably. I have always contended that the best remedy for seasickness is to eat, and keep on eating until one gets the better of it, but it is rough on the steward.

There were no incidents on this voyage, and after four days we were landed at a well-constructed pier at Port Lemon, and I found myself surrounded by civilization and progress worthy of any country.

Costa Rica is so well governed that I found scarcely an adventure worth recording. It is more an agricultural than a mining country. The lands are fertile and well cultivated; there are numerous mountains, among them several extinct volcanoes, which add to their interest, and in the interior there are a number of charming cities. San José, the capital, is a little metropolis, situated in a beautiful upland valley surrounded by rich coffee estates, and flanked by high mountains. The air of the uplands is cool and bracing, and the climate of San José is delightful. The city is scrupulously clean, and, though there are only about twenty-five thousand inhabitants, it is equal to 139 


\section{A R O U N D THE CARIB BEA N}

any American city of its size, and superior to most of them. The people of Costa Rica are perhaps not as hospitable as in other SpanishAmerican countries, but their republic is well governed, and its resources are under careful development; the people know they have done well, and, indeed, are rather proud of themselves and their country. As in all well-developed countries, the opportunities for business enterprises are not so good as in the rougher portions of Spanish America, but there is stability and security, items of considerable importance when figuring up the advantages of a locality. Portions of Costa Rica are still inhabited by Indian tribes, and I was anxious to visit them; particularly so at this time because the mails had brought me a commission from the American Museum of Natural History, and I was anxious to secure a series of specimens; so it was with keen interest that I prepared for an excursion to the southern jungles of Costa Rica, where I hoped to explore the territory of the Talamanca Indians. From Port Lemon I put out to sea in a little sloop crowded most uncomfortably with negro passengers. There was scarcely standing-room, but the voyage 


\section{A NDACROSS PANAMA}

would not be long, so I forced myself to be patient. Unfortunately the wind went down, and we were a day and a night on that miserable little boat, at one time tormented by the hot sun, at another cowering under a beating tropical rain; yet the negroes were always cheerful. A negro can adapt himself to any surroundings, and be happy, provided he does not have to work. For me the voyage was a time of sorrows, and I was heartily thankful when we at last reached a place called Old Harbour, and I could place my feet on terra firma once again. From here I tramped overland a few miles to the Silsola River, the boundary between Costa Rica and Panama, and from there took a canoe, travelling up the river for two days to a place called Sipurio, where, tired, dirty, and rather forlorn-looking, I knocked at the gate of a mission station maintained by a company of German Paulist Fathers. Fortunately one of the fathers was at home, and I was immediately made welcome, and for the next few days was one of their household; and I learned to thoroughly respect the missioners who were giving up their lives to serve the In- 


\section{AROUND THE CARIBBEAN}

dians, doing their own housework, and maintaining themselves as best they could.

At Sipurio there were two or three rough houses besides the mission, all built on a small, open savannah surrounded by dense jungles, through which a network of streams made their way to unite and form the Silsola. Not far away were the mountains where many of the Indians were living. Their king, I was told, lived in the low lands, not far from the mission, and I was most anxious to see him. From time to time companies of Indians came to see me, and then went away again, but the king did not come. After I had made the acquaintance and questionable friendship of a number, I told them I wanted to see their king and hold conversation with him, and a day or two later a tall, fine-looking Indian visited the mission; this was Antonio, King of the Talamancas, come himself to bid me welcome to his country.

That he was more than an average man, I saw at once. His dress was conventional: a suit of blue serge, stout boots, a clean white shirt, and a gray felt hat, which he held in his hand as he stood there gravely. A man who was born to rule, to his people a law, and 


\section{ANDACROSS PANAMA}

yet on his face an expression of sadness but not of dejection; his bearing was that of command.

We were friends at once. All have met with some whom they understood at a glance, and whom it would seem had so understood them, and so it was between myself and the Indian. Gravely Antonio gave me his hand, and said he had come to invite me to visit his houses, and next day would send men and horses. "But," he said, " ours are not like your houses. I have been in the cities; it is better there for those who are white men, and here in the woods it is better for us who are Indians." I had learned not to be eager with the Indians, and . when I had told him about myself and my country, we sat for a time together in silence. Then he called his attendant, and, mounting his horse, went away, riding slowly over a meadow, and then disappeared in the jungles. What a grand man, I thought. Yet Antonio, King of the Talamancas, has a reputation for unreasoning deviltry and uncontrolled passions throughout all Costa Rica.

That day I could do little; preparations were made for my visit, and then nothing remained but to wait. 


\section{CHAPTER XVI.}

THE DEATH DANCE OF THE TALAMANCA INDIANS

When the sun of the next afternoon hung heavy, and from the jungle long shadows began reaching over the meadows, three Indians came riding to the mission. A few words of welcome, a little advice from the fathers, who were somewhat disturbed at my going, and I was ready. My guides were fine men, but not nearly so large or so strong as Antonio; perhaps he was of a more ancient blood, or descended from those who in centuries past had conquered the men of the woodlands, and, ruling, had kept themselves somewhat apart from those who served; the difference was marked, and must have had causes other than climate or conditions of living.

After travelling an hour or more through the jungles, we came to a clearing and saw a number 


\section{A NDACROSS PANAMA}

of huts, and further on a great conical building like a round tent, but thatched from the ground to the peak with palm leaves and straw. Here Antonio was waiting with a grave welcome; seats were brought for my guides, a hammock for me. In the house it was twilight; at the door the bright rays of the sunset; above us the roof was so high it was dark, like a cave; a fire burned low at one side of the house, great earthen jars standing near it; many Indians were sitting about talking softly or resting in silence; yet the house was so large I could distinguish only their forms. A shed protected the entrance from the rains, and formed an open veranda where horses were tied, and the Indians gathered at times, though for the greater part they sought the deep twilight within their strange house.

For a time we were silent. Antonio, holding a staff, his insignia of office, was listening to low, earnest voices from men grouped about him. They presently finished, and then, at a sign from Antonio, women and boys came, passing large gourds of chicha. The Indians drank eagerly, but for me I would much have preferred to decline; I knew better, however, and drank about 


\section{AROUND THE CARIBBEAN}

a pint or two of the sour stuff, said it was good, and asked them for more, and it did me not the least bit of good to wish that I hadn't. We sat for awhile, then Antonio said we would go to a dance for the dead which that night would be most impressive. Horses were ordered, and I found that my eagerness need not be concealed; even the King became animated, and expectant Indians were awaiting a signal that they might proceed on their way; rather strange it all seemed, a funeral, yet so much expectation of pleasure. While we were waiting, I stopped to speak to a group of boys who were looking at me intently. Among them was a lad of some sixteen years who was taller and better appearing; his face indicated a sensitive nature and intelligence of a high order. I asked him his name. He looked surprised, and then replied: "Me? I am Josecito." This was the heir to the King, and no prince could have shown greater pride in his rank. Then immediately all was forgotten in his eager desire to see the few things that I carried, and to hear of the great world beyond the deep jungles; and this boy would be king, but a ruler of what? Of tribal legends and of the influence they brought - 


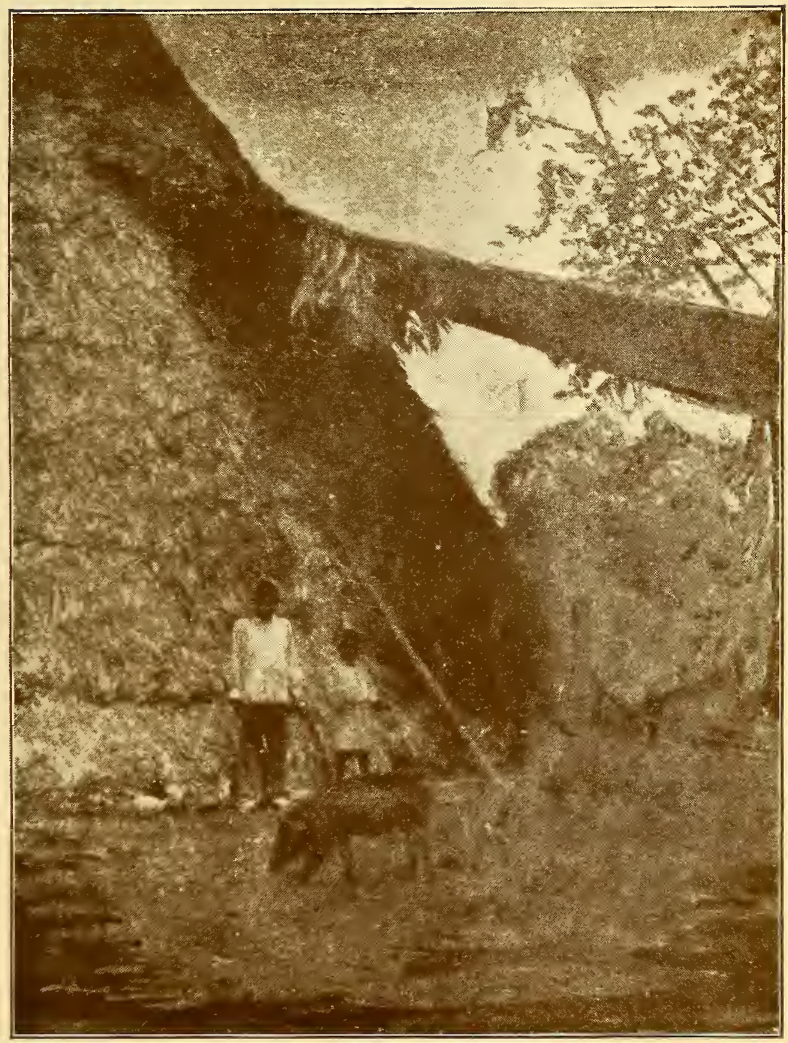





\section{A NDACROSS PANAMA}

that is all. Now Antonio came and he and his household were ready, a goodly company, who conducted me to another large house, where we arrived at that time in the tropics when, after sunset, night seems to rise out of the jungles. Here I found a great number of Indians gathered together. We were welcomed, but most of the people looked strangely at me, and then turned to the King with expressions of wonder, and soon the leading men had gathered about him, all earnestly talking. Then Antonio, raising the staff of his office, entered the house, the other men following. I went in too, for I wished to see all that was done, and my action met with approval; a hammock was brought, in which I sat watching with interest while Antonio, his principal men gathered around him, held consultation the same as he had done before. The King said little, though he listened with care to those who wished to speak with him, and then, when all had finished, he raised his staff, and in a few words gave his decision. Then some of the men came to me with a welcome; the decision had been in my favour, and I should see all, and, waiting, made myself patient. 


\section{AROUND THE CARIB BEA N}

It was now grown dark, but in the large house a fire and numerous torches sent a bright, wavering light through the midst of the Indians and high up above them, till the roof could be seen through the masses of smoke which, in the damp air, hung heavily drooping.

Men and boys now came serving out chicha, great gourds full, giving me more than enough. Then all sat around laughing and talking while the night grew about them, and the air became heavy with dampness. After some time had passed, a deep-toned drum, a musical, resonant sound, called for attention; then, to the slow measured beatings, four men went to the back of the house and stood shoulder to shoulder, facing the people and keeping measured time with their feet. Then two others joined them; these wore crowns of white feathers and carried gourd rattles. After a time one other came, in his hand a small implement made of hard wood which, on being struck, gave a sharp clicking sound; then immediately men and boys came to the line, each with a drum - or tambor, in the Indian tongue, a word in a measure expressive of the sound made when they are beaten with the palm of one's hand. In line with the 


\section{A NDACROSS PANAMA}

dancers, I saw Josecito standing expectant, on his head a crown of white feathers, under the left arm a tambor; he looked brave and most strikingly handsome.

When the line had been formed, the men who first took their places began a weird chant in low voices, taken up one after the other, and then in unison chanting together; a sound not unmusical and something like that of a wind sighing among many trees and their branches. Then a tremulous sound rose up with the chanting, as the men with gourd rattles now gave them a circular motion, then a sharp clicking came, as the Indian who carried the small wooden object beat a time on it; with that the long line of dancers swayed for a moment and then, in a slow, measured step, began to move forward and backward, with the tambors steadily beating, the continued tremulous sound of the rattling gourds, the sharp clicking timebeat, the drawn-out chant of the singers rising and falling in rhythmic, monotonous cadence; a long line of Indians, impressive because they were deeply in earnest, parading and chanting farewell to their dead. In perfect unison the Indians went through the performance, while 149 


\section{AROUND THE CARIBBEAN}

the fire burned low, and the torches, unattended, now flickered dimly; but the Indians continued steadily forward a step; a pause; a step; backward a step, a step; gradually gaining a little ground forward toward the eastern side of the house to which the line was now turned, where high above them, rudely fashioned and made fast to the thatched side of the house, were three packages, bound securely with leaves, the bones of their dead awaiting final interment. A long time the dance was continued till a place just under the dead had been reached. Then the chanting became more subdued, the wailing notes long drawn out, the tambors, touched lightly, gave a soft, mournful sound, and the rattling fell to a whispering murmur, then the balancing steps were scarce more than a swaying, till gradually all became still, stood silent an instant, and then, without anything further, went quietly back to their various places; and in a few moments boys and young men came bringing gourds full of chicha, while in all parts of the house subdued voices were heard.

A long interval, during which some fell asleep, then a dance was formed as before, this time the King taking the central position, his staff 




\section{A N D A ROSS PANAMA}

in his hand, on his head a crown of white feathers surmounted by long, brilliant plumes. In this dance the motion was slower, the singing subdued, but in other respects it was quite the same as the first.

Now it was late, and when this dance had been finished I found my eyes heavy; my thought was to sit up all night, but the chicha, the smoke, the slow, droning music, brought sleep to my eyes; I could not keep awake. The King came to me and said in a voice of concern: "What, are you sleeping? My house would be better." I roused myself, but presently nature would claim her due, and as most of the Indians were now sleeping soundly, I gave up the struggle, and the next thing I knew it was morning. A chilly gray light and a damp, clinging fog came in through the door, of the Indians, some were still sleeping and some moving about at various duties. The King came to ask me how I had rested, and to say that there would be still other dances after the morning had grown a little. Then we went to a stream near the house, where we washed and prepared for the day, the King taking charge of me with a care almost tender; on his face a 


\section{AROUND THE CARIBBEA N}

serious, unmoved expression. Then back to the house, more chicha, and with it gourds of boiled chocolate, which I was glad to receive, for I was now well hungry.

A deep red glow began rising over the fog; the sun would soon come, and the Indians began to form for a dance which clearly would be something much more elaborate. As before, the singers, rattlers, and principal men first took their places in a row at the back of the house; then at either end of the row other Indians placed themselves in line at right angles. Now the wailing chant was begun, then the tremulous rattling, and after that the sharp, clicking sound, and when this commenced three Indians bearing a light staff between them came with slow steps and stood back of the singers. On the staff I noticed three rings tied together and made of bark rudely plaited, and I fell to wondering what they might mean; then a soft beating was made on the tambors, and an Indian came, in his hand a brilliant red feather, its base wrapped in a green leaf, and he took a place facing the singers. The Indians holding the tambors increased the force of their slow, measured beating, till the whole house was full of the 


\section{A ND ACROSS PANAMA}

deep reverberations, mingled with the weird chant of the singers, the tremulous rattling, and the sharp, clicking sound. Then slowly forward and back, as before, went the line of singers, musicians, and principal men, but those at the sides remained still; the Indian bearing the feather went through the same steps in front of the singers, moving backward or forward as they advanced or retreated, and in the same manner and on the same step the three Indians bearing the staff came following after. This movement for a time was continued; the tambors, beating slowly at first, were now touched more rapidly, and gradually increased till, with sudden energy, the men at the sides broke the lines in which they were standing, and in groups of four, with shoulder pressed against shoulder, began a movement with a long step forward, a step to the side, and another step back, all in the most perfect order, circling round and round the ceremonious dancers, who continued steadily on as before. Faster and faster the outer dancers beat on their tambors, keeping time with their steps, not any one faltering, but in companies swept on around and around, till the time was set at so rapid a pace that all 153 


\section{AROUND THE CARIBBEAN}

could not keep it; and now each company bent every effort to run into and break up the party who danced just before them. A game of rare skill, the step must never be broken, each group pressed on to the next, and in turn was beset by the group following after, while in the centre the ceremonious dancers, continuing on with wailing chant, and its accompaniment of weird sounds, were not once disturbed. This required real skill from those dancing around them. Now all was excitement; the young men forced the dance to their utmost, the women with praise or reproach sat eagerly watching. Josecito, the young prince, was leading one party, and a better dancer could scarce be imagined. As the dance continued, one group, then another, was run down and forced to one side, till, finally, Josecito with his men, and a group of much stronger Indians were all who remained, and it now became a race of endurance. For a time the honours were even, but Josecito was only sixteen, those with him nothing but boys; their opponents were older and stronger. The younger party grew tired, faltered, lost the step, tried to recover, made a bad start, lost the step once again, and then, sweeping on, the 


\section{ANDACROSS PANAMA}

older men passed among them, their line was destroyed, and Josecito, red in the face, ran out of the house to hide his confusion. The remaining group circled round the ceremonious dancers, going gradually slower, till they stopped and stood at one side, beating softly on their tambors. Then the ceremonious dancers turned to the remains of their dead, and the chant died away in a wailing farewell which could not be misunderstood. Then, after standing a moment in silence, all returned to their places. Josecito looked in at the door, and then ran away, as if ashamed of his failure. For a time the Indians all rested, then a new dance was formed, different again from the others in that the women prepared to dance with the men. The singers, musicians, and principal men stood as they had done before, the chant and the step were the same, the accompaniment in no way different; but, as the beating of the tambors came quicker, the women began to dance round and round, as the boys had done, except that they danced hand in hand, while the boys held their lines by pressing shoulder to shoulder, and keeping the most perfect time in their steps. The women gave little attention to time 155 


\section{AROUND THE CARIBBEAN}

and the step, but they danced with an abandon of motion which was most attractive. As the dance progressed, it became much confused, and was pushed rapidly on to its end; then came the wailing farewell, and the Indians returned to their seats or stood about talking together.

More chicha was served, and then the King said that, as I had seen all the dances, we would go to his house and sit for a time, if I wished. Taking leave was of very small moment, the same as I had found it among other tribes, and even the King was not noticed; we simply walked out of the house; that was all. Shortly we arrived at the King's home, and in the deep shadowy interior sat at ease resting. Then I said: "Don Antonio, why do you dance for the dead? I have seen, but I want to know what it all means." With an expression of real regret on his face, the King shook his head, saying: "No, my white visitor, I love you much, but the dances they are of the Sukias and the Singers. I, as King, know all, truly, but to tell or not that belongs only to them. And yet why should we keep these secrets? I am not a king; as the government commands, so I do; our secrets mean little now. For myself I wish 


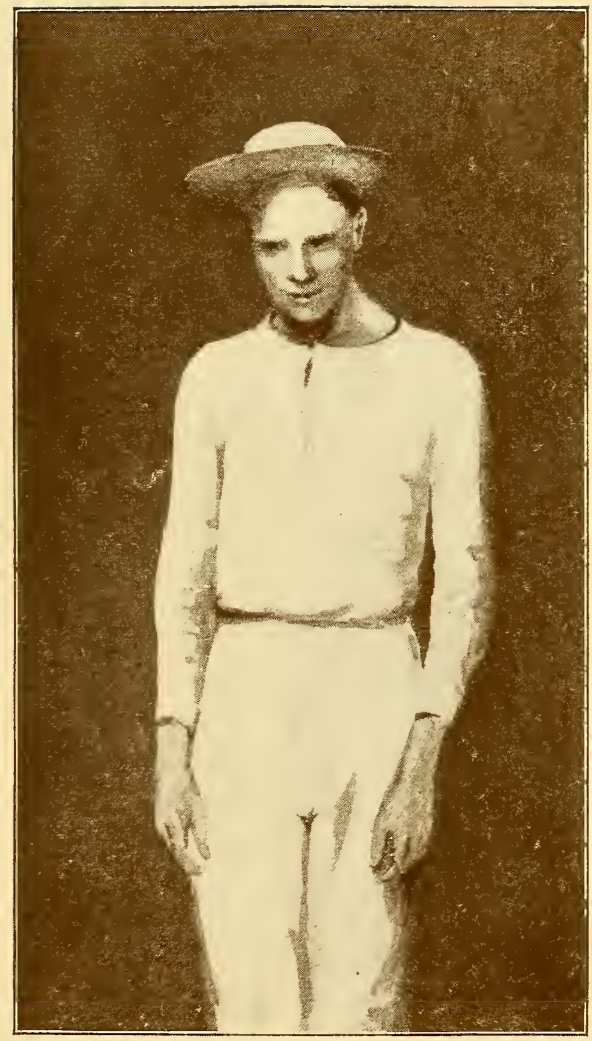





\section{A N D A ROS PANAMA}

you to know. A Sukia will come; be patient and wait." So we waited and the Sukia came, and when he had talked with the King he said, gravely, to me: "Why do you want to know of our dead, you of a far distant country; what is it to you?"

I answered, explaining that I was sent by the American Museum of Natural History, a great palace as big almost as a mountain, where records of all the Indians were kept that none might be lost or forgotten - a record that should be for them, their children, and all people for ever. Then I told of the museum and the work it had done; this caught their fancy, and when I had talked a long time and answered their questions, the King said: "It is good. I no longer am King; those who command and send soldiers care not at all, and lest everything should be forgotten we will tell you. Our word is, we will tell you; your word is, you will keep the record for us, for our children and for all who may care to know. Were I a king we would keep for ourselves our remembrances; to-day our power is gone; to-morrow we may not be at all.

"I, Antonio, am King, the oldest son first $15 \%$ 
born of the other King's oldest sister; so it has been always. Not the son of the King, but the son of the King's oldest sister, for who knows that a son born to the King's women might be not of his blood. The people obey the King, and next to the King are the Sukias - wise men who charm away evil, keep the Bugaru (chief evil spirit) from destroying the people, and who, with their charms, save the sick from the influence of the spirits of evil which for ever are seeking to injure the living; and all believe in and follow the word of the Sukias. The chief Sukia is wise beyond the others; him all fear; he lives deep in the mountains and seldom is seen. Even the King has fear of him, and before him the Bugaru never can stand.

"After the Sukias are the Becockaras, who watch over the food, the fields, and the cattle; with them all people consult and find wisdom for their planting, their hunting, their going away, and their coming again.

"Apart from all are the Singers, who commune with the dead, and watch over those who have been taken from us. When a man dies he is gone, and wants no more of the things 


\section{A N D ACROSS PANAMA}

which were here; and, as he wants them not, we in due time make a feast, eating and drinking. We do not give what he had to his sons and his women; in the woods there is plenty, and the fields yield enough; if they work, they have no want of things which belonged to the dead. Let them work and take from the earth that which is fresh and good for their lives; but if they care not to work, they are not worthy to have. The people who rule tell us this is wrong; we do not hold it a wrong.

"When one is dead, those who are appointed to handle the body take it away to the woods; there, bound securely with cloth and with leaves, and placed in a house made of poles, the body remains for a year, till the sun rises again on the day of that life's departure; and if the bones are found cleaned by the wind and the rain, it is well; the body is freed from the flesh, and can then be taken high in the mountains to be buried in the great vaults which were made in days so long gone past that none remember their making, only we know that there all are gathered together; but before the bones are taken away, we dance and rejoice, bcause now they are safe, and this we do dancing, drinking, and 


\section{AROUND THE CARIBBEAN}

eating till all that belonged to the dead is consumed. Then the family take up the bones and go by themselves to the safe place high in the mountains, and when they have laid the dead in the vault which is theirs, for each family has one, they leave a few things, that the dead may not be in want, or be sent away emptyhanded; not that we think the things will be needed, but only because it has been so always; then the family come home again to the lowlands.

"The dances you saw were in farewell and rejoicing, because those departed were safe. The first dance was held for a woman. You saw it. She had served the men well, and they danced for her who had left them. The second dance was for a man, and his companions danced in his memory; you saw the singers in farewell, as at first, but with others joining to aid and remember. The young men about the singers represented the struggles of the life which had been and which for them would still be. Behind those who sang were three bearing a staff, and on the staff was a snake of the lowlands, a type of the evil which the dead were now leaving behind them for ever; and before those who 


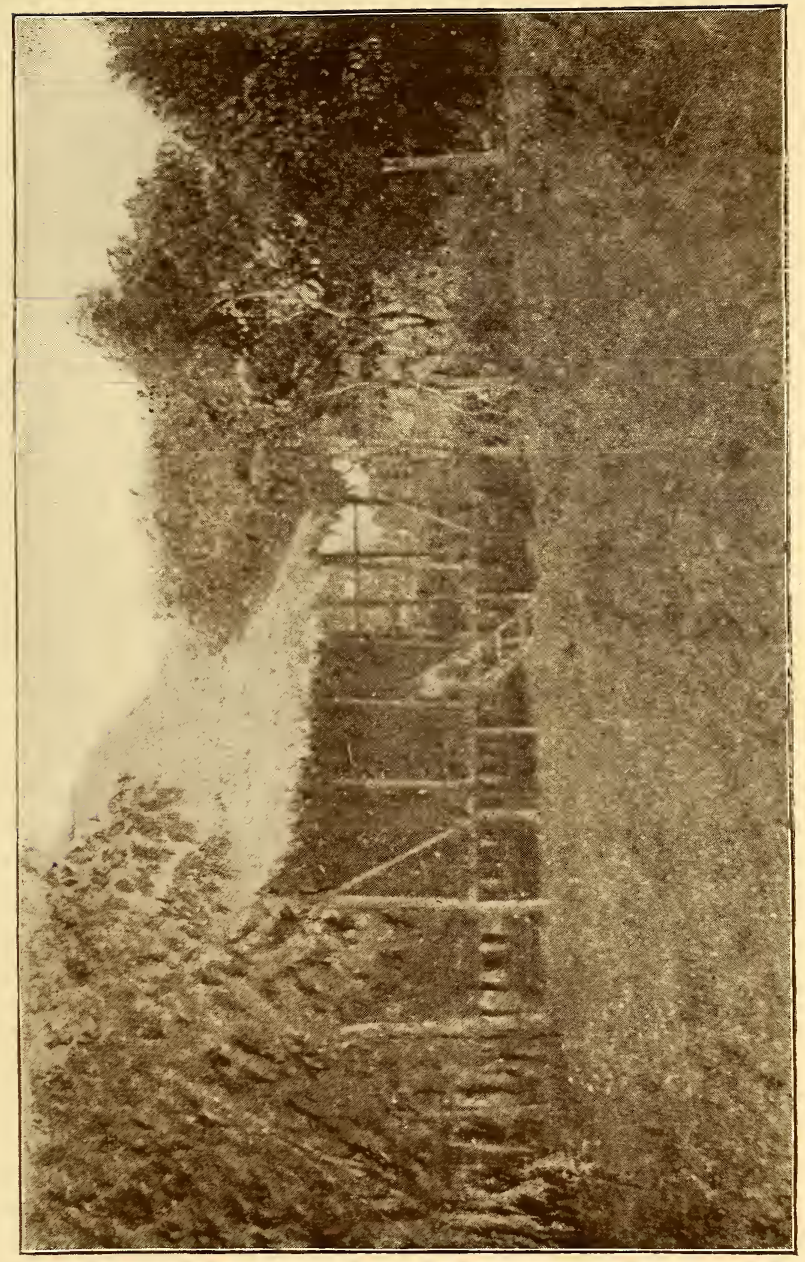





\section{ANDACROSS PANAMA}

danced and sang in farewell was one bearing a feather from a bird of the mountains; and dancing he was a spirit, a bird leading and calling on to the mountains where the dead were to rest and would be safe for ever.

"The last dance was for a child only; the farewell was the same, but the women to whom is confided the care of the children danced round about hand in hand in token of life and its struggles; but not in order; they danced in and out among those who sang, for the child's life had been broken, and so was their dance.

"This is all; it is little; only farewell to the dead. Not that they need it, but only that it has been so always; it is our custom and it is nothing more."

Then Antonio, the King, stopped talking. Beyond the deep shade of his cave-like house was the intense burning heat of the tropics; a shimmering of light over the green of the jungles; a wavering of intense heat over the grass in the clearing in front of his houses. Quietly the cattle and horses were feeding; scarce a breath stirred. Antonio the King looked over the scene a long time in silence, and then said, as if thinking aloud: "For the white 


\section{AROUND THE CARIB BEAN}

men the cities, plantations, the ships; for the Indians only the forests. Why will they not leave us our own?"

There was much that I wanted to know beside what had been told, and I asked the King how the dead were finally buried, to which he replied: " There is little ceremony; the package of bones is placed in a hammock and carried to the burying-ground in the mountains; the top of the vault is removed, and the dead laid away with those who had gone before them; the vault is covered again, and by its side we leave a stool to sit on, a clay jar for chicha, a cup for drinking, a gourd, and for each man a bow, arrows, hunting-bag, and his walking-staff; for each woman a basket. We do not think the dead need these things; it is only a custom."

Would they show me the burying-ground? Decidedly they would not, because they knew the white men would dig open the vaults and take the bones of their dead, an act they all feared, the King saying: "That is a curious custom of yours. Your people want our dead, yet never think of disturbing your own. Why do you this? We cannot tell, and do not hear your words of excuse." 


\section{AND ACROSS PANAMA}

Then I said: "Don Antonio, ask them to sell me all the things they use in a dance of farewell, that I may make a dance for myself."

"Without the dead? That would be foul," and the face of the King wore a grave, anxious look.

"But," I urged, "one will die; let me have these things, for the dance is good."

Then Antonio said: "What harm can it do?" and to the men standing near: "Get the things for him, that, knowing all, he may even dance for himself if he will."

Agreements were quickly made, and I was promised that in a few days the collection would be completed.

Then the King brought out the regalia and let me take the things in my hand. The staff of office was of very hard wood, a bird's head carved at the top, the throat hollow and containing a ball with which a clear, rattling sound could be made. The crown was of feathers, a circle of white plumes from the eagle, with long red and blue tail feathers from the mackaw standing erect at the front, while around the base of the crown were iridescent feathers, green, red, blue, and yellow, cleverly blended together. Around 


\section{AROUND THE CARIBBEA N}

his neck were hung seven golden eagles, identical in form with others found among the most ancient graves in Costa Rica. He had also a string of shell beads like those found in old graves, and called pre-Colombian.

When I had seen the regalia, the King said he was obliged to leave me alone for a time, because some Indians had called him.

I went to the hut where I was to live, thinking of all $I$ had seen and wondering by what means more could be learned. I was commissioned to make a collection, and the idea took my fancy that the model of a dead Indian, and a second model of the bones prepared for the dance and final interment would be specimens well worth the effort. To prepare the model I had only some string and my knife, but in the tropics nature is lavish, and with the aid of some of the younger Indians, who appeared immensely amused at what I proposed, material was found in abundance. A young Indian willingly stood for a model, and after taking measurements carefully, I began the construction. A gourd served very well for a head; a young bushy tree provided a collar-bone, spine, and the ribs, which were bent into shape 


\section{A NDACROSS PANAMA}

with my bits of string. A second gourd carefully cut made a good imitation of thighs, and jointed pieces of wood formed the legs, arms, feet, and hands. Then the body was padded with straw till its appearance became really natural, and the young Indians said it was truly a " deader." Then I told them that the body was my Uncle Gabriel, and that I must have him laid out in the woods, because he was dead. The men objected, of course, but they yielded after a time. Cloth was procured, and the body wrapped snugly, and an outer covering of green leaves bound securely around it. The bows, arrows, staff, cup, and hunting-bag were bound together and laid on its right side; a stool was brought and placed at its feet, and by the left hand was placed a jar for chicha. Then I asked them to take up the model and prepare a place in the woods where it might stay for a year. This they positively refused; yet I forced them, urging, threatening, and commanding. Then one said: "This is bad, but we finish. Take up your deader and come." We started at once, but warning cries of horror and fear came from the women. The men stopped, but by some influence, I hardly know how, I made them go 165 


\section{AROUND THE CARIBBEAN}

on. In the woods the work was soon done. First a little place was cleared in a thicket; then poles were laid on the ground, a few leaves put over them, and on these the model was placed. Around it slender poles were forced in the ground, and all bound tightly together, forming a cage in which a body would stay a long time well secured; about it the staff, bow, arrows, and hunting-bag, the stool, and the jar for chicha were laid as before; that was all, and seemed very little to have required such effort. The cage was taken up, the pieces carefully labelled that they might be put together again in New York, and the specimens were thus carried back to the hut in which I was living. On the way we saw frightened women run to hide in the King's house, though some stood at a distance looking at us with wondering caution.

In regard to the objects used in the dances, the King's orders were being obeyed, and all the implements were freely brought to me, all but the wooden instrument on which the clicking sound was made. There was but one in the tribe, which had been handed down from time immemorial, and no one had any idea of making 


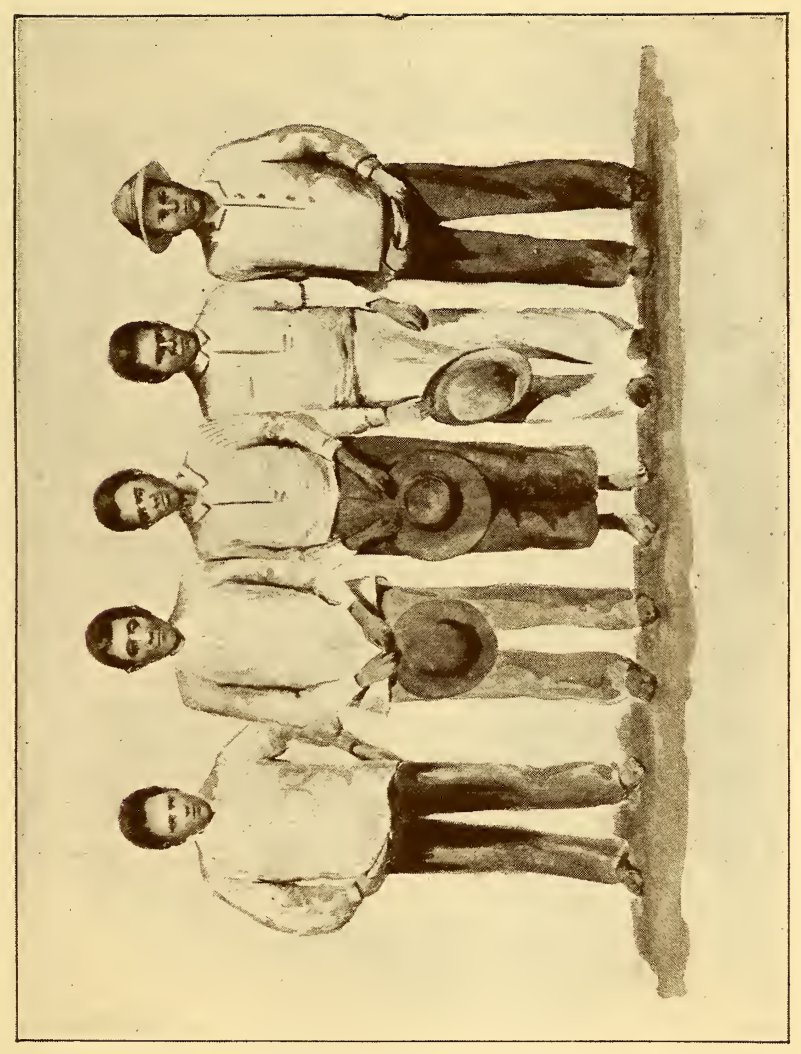





\section{A NDACROSS PANAMA}

another, but as dances were held without it, because it were impossible that the instrument should be at the service of all, I did not consider it of such great importance. I was most anxious to secure a model of the bones as prepared for final interment, and now sat in my house planning how this should be done, and listening to frightened voices and exclamations of anger from Indians in the King's house, where they had gathered together. How long they continued I do not remember, for when evening came I went to my hammock, taking my pistol with me as usual, and soon fell asleep, leaving my plans and the Indians till morning.

The next day I found everything quiet again, and set to work preparing my skeleton model. It was not easy work, for material was scarce. The head was a gourd, branches and bits of wood formed the bones, a hollow stick cut in sections represented the spine, and from a large gourd thigh bones were made. Then all were laid out on the floor, each bit of wood in the place where a bone should have been. The effect was so natural that the Indians were frightened; then they became interested, and when I said the bones were those of my Uncle Gabriel, re167 


\section{A ROUND THE CARIB BEA N}

cently dead, and that I must have them prepared for a dance I would hold in New York, they looked at me in wonder, hesitated, and then prepared to obey. A cloth was brought, and the mimic skull carefully taken, the collar-bones were thrust into the opening to hold it in place, the ribs were forced through the sections representing the spine, and all were laid on the cloth, the skull at the top; then at either side they placed the bones of the arms, the bits of wood representing the fingers and hands were placed in little piles at the base of the arms; the thigh bones were placed where the stomach would be, the legs were put in position, at the end of each were placed the bits of wood which represented the bones of the feet; then the cloth was folded over, and the compact little package bound tightly with cords; leaves were brought from the forest, and the final binding was being put on, when a tumult of wailing and outcry came from the women; something was shouted in a horrified voice, which was immediately taken up by all of the people. The men started back, and, looking at me with terror, refused to proceed with the work. I was determined to make them, and would not allow 


\section{A N D ACROSS PANAMA}

them to go out of the house. Perhaps they feared me more than my model; at any rate, after a moment, they turned again to their work, and, with faces perspiring and hands that were trembling, they finished it all. I ordered them then to prepare a support, and place the model on it as if it were there for a dance; this they did, while the women shouted denunciations and cried out in fear. When all had been finished, two bits of wood, one hard and one soft, in which a fire had been kindled by friction, were placed under the leaves surrounding the package of bones, and the dead was provided with fire. A hammock was brought in which the remains could be carried; that was all, and then my collection was finished. The men hurried away, saying that never would they again enter that house, which they now held had been cursed. The women had all disappeared, and I noticed as I packed up my specimens that everywhere there was an ominous silence; perhaps my investigations would yet cost me dear. In the afternoon Josecito came to say that he wanted me to sleep at his house. I wanted to go, but who would care for my specimens? No, I determined that $\mathbf{I}$ would remain, and Josecito rode 169 


\section{AROUND THE CARIBBEAN}

slowly away. That evening the women came back, but there was no supper for me. I passed an anxious night, and yet nothing happened. In the morning I gathered my specimens together, intending to start for the clearings, where the Costa Rican Governor was living, but here were new troubles. No Indian would touch the evil things I had made, and it was evident they did not intend to permit me to take them myself. I had no thought of yielding, so a contest of wills was begun; yet for me the time was not lost, for I set to work to learn the words of their chant, and after getting a fragment from one or another I began to have some idea of it all. The words were known, but they belonged to a language which had been lost, and even the singers had no idea of their meaning. From a drunken Indian who happened that way I finally got all the words together, after a rather comical experience, in which I started a rough singing contest, though I cannot claim any voice except one which is at its best only when silent; yet it now served the purpose, and after awhile the Indian took up the singing and began to chant their farewell to the dead; the words were repeated over and 


\section{A NDACROSS PANAMA}

over, and as he sang I set them down as they are here:

$\mathbf{K}$, ah la u ha ma ta ka bi, su na ka bi a ya, da shang huan.
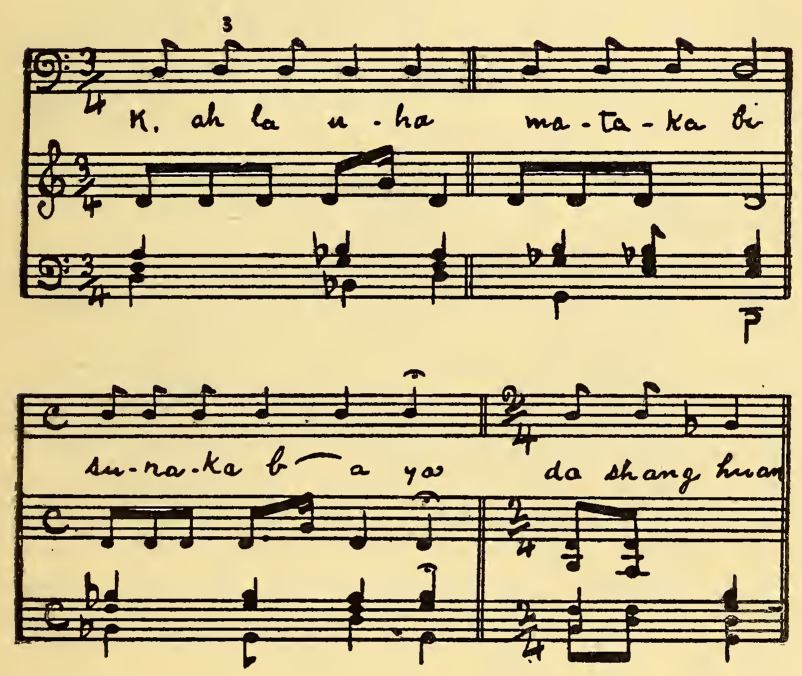

(In the musical notation, as here given, the endeavour has been made in the arrangement to render the death chant as it sounds when the Indians are singing together in discord and in irregular time according to their custom. The 171 


\section{A ROU N D THE CARIB BEA N}

air is the monotone accented chant as it sounds when sung by one Indian as a solo.)

This was an addition to my collection of material, but I was no nearer getting away with it all. The Indians grinned complacently, and even came to look at the specimens, but touch them - not for anything. That evening Antonio the King returned, and I thought my troubles were over, but I am sorry to say that Antonio was very drunk. I was still in his favour, and though now all the Indians cowered before him, I had nothing to fear. He neither approved nor disapproved of my specimens, and even apologized for his condition, blaming it all on the Christians, as he called the white men, who talked so fair but would not trade till they had given them drink, and then when the Indians were happy and careless made unfair exchange, and sent them home almost empty handed. Then he looked away to the woodlands with sad, drunken eyes, saying over and over: "I am not a King, I am not a King, or they would not do this."

Antonio said he could not order the men to carry my things; it was theirs to do or not 


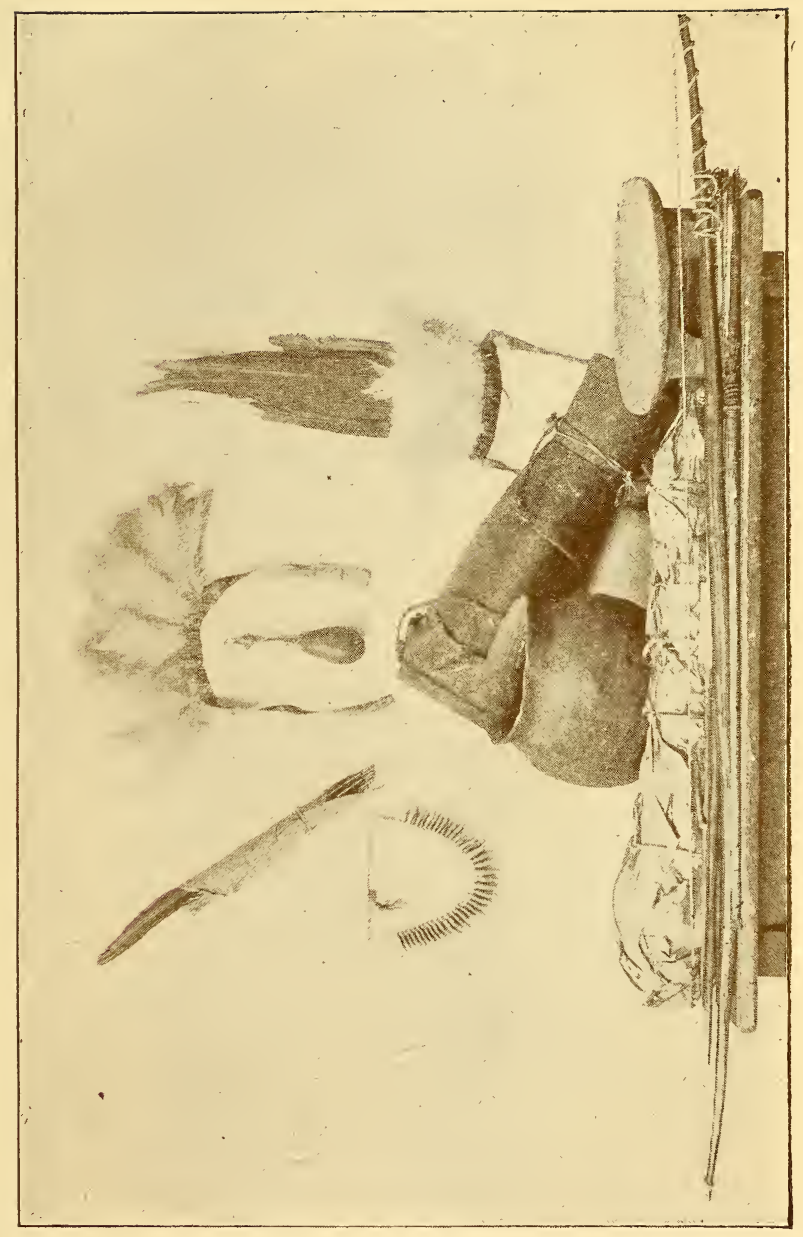





\section{A N D ACROSS PANAMA}

as they pleased. Only for himself he could say I might take them; that was all he could do.

That night I sent the Governor a letter, telling him of my difficulties and asking his aid, and next morning three soldiers with a number of mules appeared at my house, much to my surprise, and said that the Governor had sent them to help me. The Indians looked on in amazement and fear, but made no objection; then, while the specimens were being packed on the mules, Antonio the King came, saying: "I ride beside you, and Josecito has gone to ride on before you."

As we went through the jungles in silence, we frequently met with bands of armed Indians who, on seeing the King, followed, but did me no harm, and presently a goodly company had gathered together, escorting me on through the woods. After a time we stopped, and the King said: "I go no further. We are now near the Governor, and he is against me." Then, extending his hand, he said, as I grasped it: "Goodbye, come again; I love you much." Then all the Indians left us, and I soon reached the government buildings, where there was nothing to do but to express my deep thanks to the Gov- 


\section{AROUND THE CARIBBEAN}

ernor, who would not allow me to pay for the mules or the soldiers.

Before leaving that country I met a Sukia who had come to the government buildings, and to test what I knew of the farewell chant to the dead, I sang it for him, and the surprised, angry look on his face, as he demanded where I had learned it, gave me assurance that I had not been misled, and that it was in truth the death chant of the Talamancas. 


\section{A NDACROSS PANAMA}

\section{CHAPTER XVII.}

UP THE ATRATO RIVER IN COLOMBIA

After a few days I left Sipurio, and spent a little time examining the jungles and rubber forests of Northern Panama. Rubber is not so abundant in those regions as formerly, but the lands are magnificently rich, the streams clear and pleasant, and the mountainsides cool and healthy. Everywhere young rubber-trees were coming up through the woods, and if a system of forestry were established, and maintained, all the jungles would soon become abundantly productive of rubber; but at present the search is so eager, and unrestrained, that before a young rubber-tree reaches the period of seeding, it is girdled and killed. Under such a system, rubber is fast disappearing from both Costa Rica and Panama.

After acquiring some lands for the company 175 
I represented, I returned to Port Lemon, and presently took a steamer for Cartagena, Colombia.

The voyage was for two days only, and, arriving at the ancient capital of Spain in America, I found myself in an interesting old city, where the streets were narrow and the ancient buildings rich in memories of Spanish colonial grandeur; all enclosed by a great stone wall, which in former days made this city the impregnable stronghold of the early Spanish rulers in America. Cartagena is not large, and in a few hours all the points of interest can be seen, and, after that, time and the sultry air hang heavily.

For a few days I wandered about the city and surrounding country, and then took passage on a dilapidated little steam-tug, en route for the Darien regions, where I expected to make a series of explorations.

I was impressed with the necessity for restrictions in regard to passenger service in dangerously weak steamers. In most countries the little boat in which I was travelling would have been condemned and sold for old junk, but in South America she was allowed to go to sea, 


\section{AND ACROSS PANAMA}

though whether she would ever come back was a very serious question. On the way the machinery broke down several times, and once or twice her position became really dangerous, and during the whole voyage the situation was serious.

We ran pretty well out to sea, though the water was quite rough. Once, when the wind was at its height, I noticed two white specks on the horizon, which seemed to be rapidly approaching. Presently I saw that they were Indian canoes, nothing but shallow dugouts, yet, managed by the Indians, they were skimming over the waves like birds, till I wondered at the dexterity with which they were handled.

One afternoon we turned toward the land, the captain looking anxiously ahead, and I noticed that the men, too, were peering at the water as if in fear, and I saw one cross himself reverently, after the manner of the country.

I asked him why he did this, and he replied, "Because, señor, there are many dead here."

"How so?" I asked.

"The Needles," he said. "Don't you know about them?"

"No, tell me."

177 


\section{AROUND THE CARIBBEA N}

"They are sunken rocks, with long, sharp points, out here for miles northward of Eagle Point; but they just show their tips above water. Wait and you will see."

A few moments later there was slight disturbance in the water, and a wave curled up and foamed over.

"That is one," he said, "but it seldom shows itself. There are others further on."

Presently he pointed and said, "Look there." I saw a ripple of foam circling around a wave, then suddenly a number of long black points seemed to rise up out of the water and stealthily disappeared again.

Then a wave curled up where they had been and the water was all quiet once more; then they rose up again, as if to menace the ship, and then mysteriously disappeared. A bit of foam marked the spot for one instant, and the sea was calm, without even a sign that there was danger. So far as I could see toward the north, there were points in the ocean where the waves rose up at times, and foamed over, making a truly dangerous place. A relieved look in the faces of the crew told me when the danger was past, and then in about half an hour we 


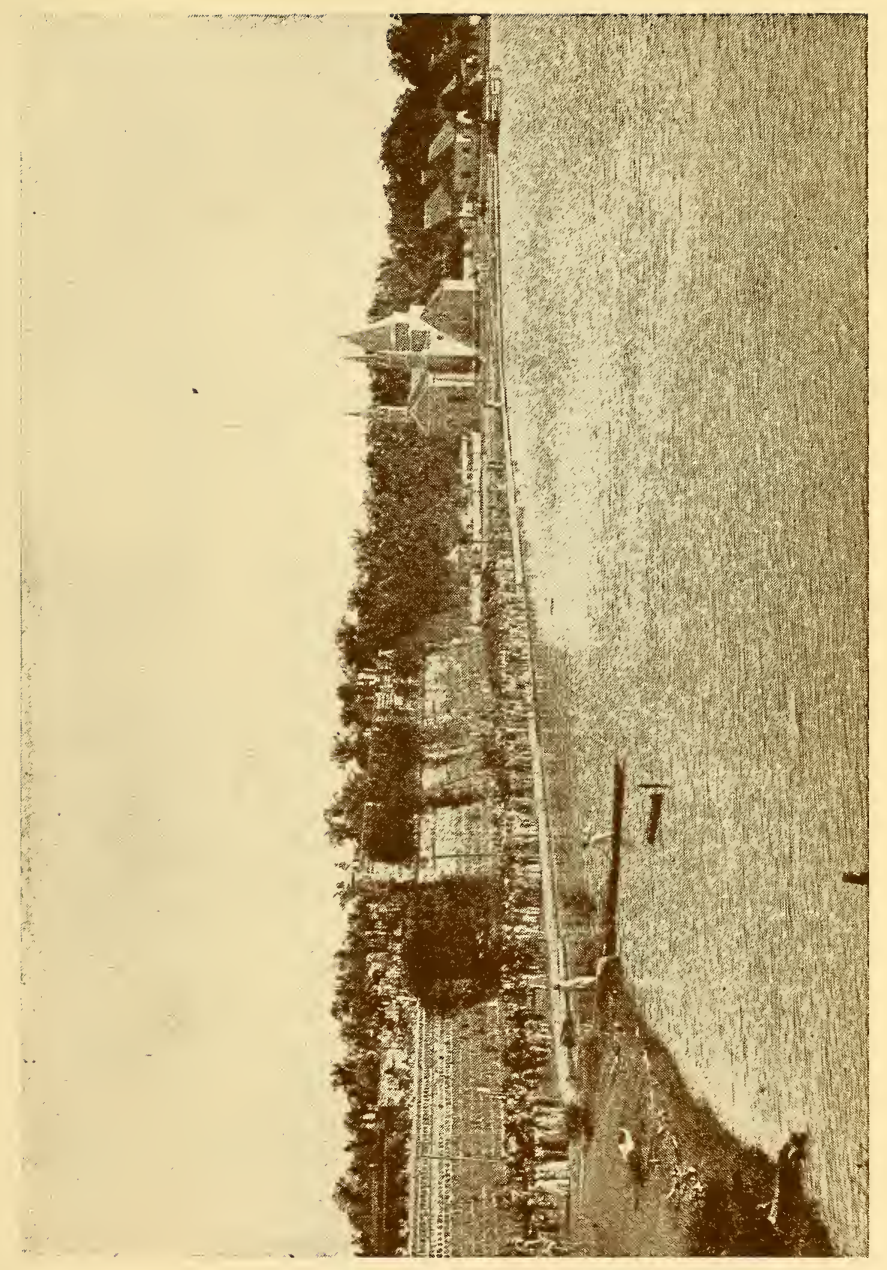





\section{A N A CROSS PANAMA}

rounded Eagle Point and were coasting along the eastern shore of the Gulf of Darien.

That night we anchored, for fear of collision with drifting logs, and, after the relief of a quiet night, made an early start, the captain hoping to get his boat over the bar at one of the numerous mouths of the delta of the Atrato River before the tide ran down, though the rise and fall was insignificant. As we approached the land, a scene of desolation unfolded itself to our view. In this country it rains so frequently that it is always expected, and now a steady downpour came falling with disconsolate persistence from the leaden skies of the morning. Then we ran close to a swampy shore, where plants struggled against the encroaching waters, and dead trees stood gaunt like skeletons.

From among the uncertain growth a flood of yellow water came pouring, and the next instant we bumped up against the bar, slid over it, and were in one of the outlets of the delta of the Atrato, and then we made our way cautiously toward the main river. Presently we reached it, and the sweeping torrent was a fitting demonstration of the volume of water which can accumulate in a country where a clear day 179 


\section{AROUND THE CARIBBEAN}

is rare, and the sun is considered worthy of remark when its rays penetrate the ever-threatening clouds.

Progress was slow against such a heavy current, the little steamer made frequent stops to take on wood, and we always tied up for the night. Frequently, while taking wood, the men uncovered snakes, scorpions, tarantulas, and centipedes; and their possible presence in the wood taken on board was a constant danger, yet the men gave little heed. They were careful not to touch a snake, but had little regard for the poisonous insects, though they were somewhat cautious if tarantulas were about; but scorpions and centipedes were scarcely noticed. At one wood-pile the men called me to see a black, or crab-scorpion, as they called it, which was, they said, as dangerous as any snake. It was a strong, illy-proportioned insect; the claws and body were heavy and broad, while the tail was short and stubby, looking strangely out of proportion. I held it down with the point of my machete, and it began to rain blows on the blade with its sting till the steel resounded from the attack. Then I crushed the ugly thing, and found it was incased in a shell, hard almost like 


\section{A NDACROSS PANAMA}

that of a crab, though the ordinary scorpion is soft, with scarcely any protection. The men said that these crab-scorpions were rare, and sometimes years would pass without one being seen; which was fortunate, for otherwise it would be a dangerous matter to handle wood and produce in that country.

Our progress was slow, and there was little to attract one's attention in the monotonous series of mud-banks, swamps, and jungles. After a few days' travelling, higher ground appeared, and a little further on we came to a forlorn-looking city called Quibdo; a little town where the native gold-washers come to sell their product, and a few merchants do a thriving business, trading goods for gold-dust. From here I took a canoe two days up the river, and established headquarters at a village called Lloro, and, on arriving, engaged two faithful guides, strong, daring men, who promised to go with me anywhere I might desire. Soon I learned that their word was good, and that they were ready to go wherever I might direct, and as to my money, I never gave a thought for its care, and didn't lose a cent.

Yet these splendid specimens of men were 181 
denounced and excommunicated by the Church, and the elder said, when I employed him, "There is only one thing: if we meet a priest, we must run and hide till he has gone."

They readily consented to tell me how this was. For a long time in that country there had been no priests, but one day a number came to establish a mission, and within a few months had gotten themselves thoroughly hated. The people had customs of their own which the priests immediately condemned, perhaps not without reason. One such custom was a civil marriage, or contract before witnesses, which had been considered sufficient. The priests said this was a sin of heresy and a direct crime against ecclesiastical law; and ordered all people to appear before them at once, that they might perform the religious ceremony according to the rites of the Church. The people were quite willing, as they did not wish to do wrong; but when they were informed that each man on his marriage would have to pay sixteen dollars they began to doubt the sincerity of the priests; and some people said openly that all the priests wanted was the sixteen dollars. Many of the 


\section{A NDACROSS PANAMA}

people did not have the money, and this brought on the trouble.

My two men had not been married in the Church, and considered themselves, their wives, and their families entirely respectable, as their mothers and fathers had been before them; and the remarkable spectacle was presented of priests as persecutors, not as friends and counsellors, but as men trying to use the force at their command to secure an end. The people did not object to the end, only to the price, which some of them did not have, and they naturally inferred that it was the price, and not the end, that the priest was seeking; because, where the money was not forthcoming, arrests followed with beating, or other punishment, even though the man was quite willing to be married according to the ecclesiastical law.

No doubt it was all a mistake. When a man said he had not the money and could not do as the priest advised, the priest probably thought he refused the rites of the Church, and when the priest spoke of a reasonable charge for the ceremony, the people, not being accustomed to ministrations from the Church, thought the requirement was for the money only, misunder183 


\section{AROUND THE CARIBBEAN}

standings and contention resulting. The only inconvenience that I suffered was because of my mackintosh, which the people took for a priestly garment, and on my arrival at a village where I was not known, many of the people took to the woods, and valuable time was lost before they could be persuaded'to return. 


\section{A NDACROSS PANAMA}

\section{CHAPTER XVIII.}

THE WILDERNESS OF THE CHOCO COUNTRY

From Lloro I started on a series of explorations, and with my two faithful guides I travelled for miles among the lowlands and mountains of the Choco country, a region some three hundred miles south of Panama. Many days were spent in long canoe voyages up strange rivers, where torrents of water went crowding and chafing along against their wooded banks. It rained frequently, but many days were clear, and, secure with faithful guides in an unknown country of strange uncertainties, I thoroughly enjoyed my explorations.

Frequently we met other parties in canoes, who were all curiosity to learn about my affairs and the object of my visit.

My men always answered that they did not know, usually replying, "He's a stranger, go- 


\section{AROUND THE CARIBBEAN}

ing here and stopping there, just as he fancies, travelling like a crazy man; perhaps he is one." Whether they thought it policy not to tell of my examinations in regard to the gold deposits of that country, or whether they really thought I was not of sound mind, I do not know, but their peculiar care of me was perhaps suggestive.

Once when we were on one of the smaller rivers, my chief guide, Profanio, called my attention to the trunk of a great tree which had fallen high above our heads across a ravine. It was worn smooth by the feet of animals that made it their regular track between the hills, and I was told that here, any night, wildcats, panthers, and jaguars could be shot as they passed across the log. It seemed a pity that I could not stay to have a shot at them, but I had come for other things, and left the place behind me with some regret.

That same night we camped well up the river, having forced the canoe as far as it would go. We had to contend for our camp, a rude hut built in the woods, with a swarm of red ants, and after considerable trouble got the place free of them. 


\section{ANDACROSS PANAMA}

Then we fixed our beds and were soon enjoying a thorough rest. I was just dozing off when I was awakened by a strange noise in the woods, something like the vibrations of a cord against a drumhead mingled with a hissing sound, at times almost a deep whistle.

Then I heard an old man who was with us say, "Companions, did you hear that?"

"Yes," said Profanio, in a sleepy voice, " it isn't coming here."

"Don't be too sure. Hark, there it is again."

"I'm not afraid," was the answer, but I noticed that Profanio was sitting up, looking anxiously in the direction of the sound.

"Is the boat where we can make it away easily?" said the old man, getting up.

"Keep still," said Profanio, "or you will have it after us."

"Better see that the Señor is awake, and ready, if we have to go."

Profanio got up softly and said to me, "We may have to run for the boat if it comes nearer. Are you ready?"

"Yes," I replied; "what is it?"

"A barabosa, don't talk," and he went softly to his place.

187 


\section{AROUND THE CARIB BEA N}

For a few minutes we heard that strange sound a little distance from the camp, and then it began to go further away, and finally it was lost in the distance.

"It's gone; I knew it wasn't coming," said Profanio, though I could tell by his voice that he was glad of it.

"It was only for the Señor," said the old man; "he did not know what to do."

Then I sat up in my hammock and said, "Profanio, what is a barabosa?"

"A big snake as large around as my arm," answered the older guide.

"Is that all?" I said.

"Yes - and it is enough. The bite is so bad that none of our remedies can cure it; and if it meets a party in the woods it will come and fight and certainly bite some one before it is killed. It is like a rattlesnake more than any other, but has a horn where it ought to have rattles. When they threaten to come into camp, we usually take to the canoes, but to-night it was not angry and did not come."

It was not long after this when I heard the two men sleeping soundly, and after listening for awhile to all the strange, murmuring sounds 


\section{ANDACROSS PANAMA}

of the deep woods, I fell asleep myself, and forgot that there was any such thing as a barabosa, and even now I am rather doubtful about it.

Another day, while we were going up a larger river, the men began telling me of great monsters, living in a black hole where the water was so deep that no one knew how far away the bottom was. Both of the men insisted that it was true, and said that the animal had been seen, and at times they caught smaller specimens. They said that to fall into the water where the big ones were living was sure death, and that several people had been killed by them.

They called the animal the quicharo, and said that it was neither fish nor alligator; that they were found from two to even twenty feet long, and were remarkable principally for a great oval-shaped head and rounded jaws set with enormous teeth. That in place of feet it had two flippers; that the widest part was just back of the head, and that the body tapered abruptly to the tail, which was not especially prominent. All the upper part of the body, they stated, was covered with rough plates, that gave it the appearance of a great brown log 189 


\section{AROUND THE CARIBBEAN}

when on rare occasions it was seen floating on the surface of the water. The smaller specimens, they said, were good to eat, but that after the plates grew the animal was all soft inside, and went to water or soft pulpy material after being caught.

Presently we came to the point where the biggest quicharos were said to live. It was a strange, mysterious-looking place, a great, round pool of dark water surrounded by rocks, with rapids just above it.

I looked over the side of the canoe and wondered what might be the real basis of their belief in this strange animal; no doubt something, but probably not at all as described. I was beyond the reach of the light of modern science, and here the people still believed in their fancied creations, and to them the world is still peopled with monsters; a mystery must take some form of expression, and is gradually built up into a figure, perhaps the exaggeration of some well-known species.

I made a great many small inquiries about this quicharo, and everybody seemed to know of it, and in general the descriptions all agreed with the outlines as given; and it may be that 


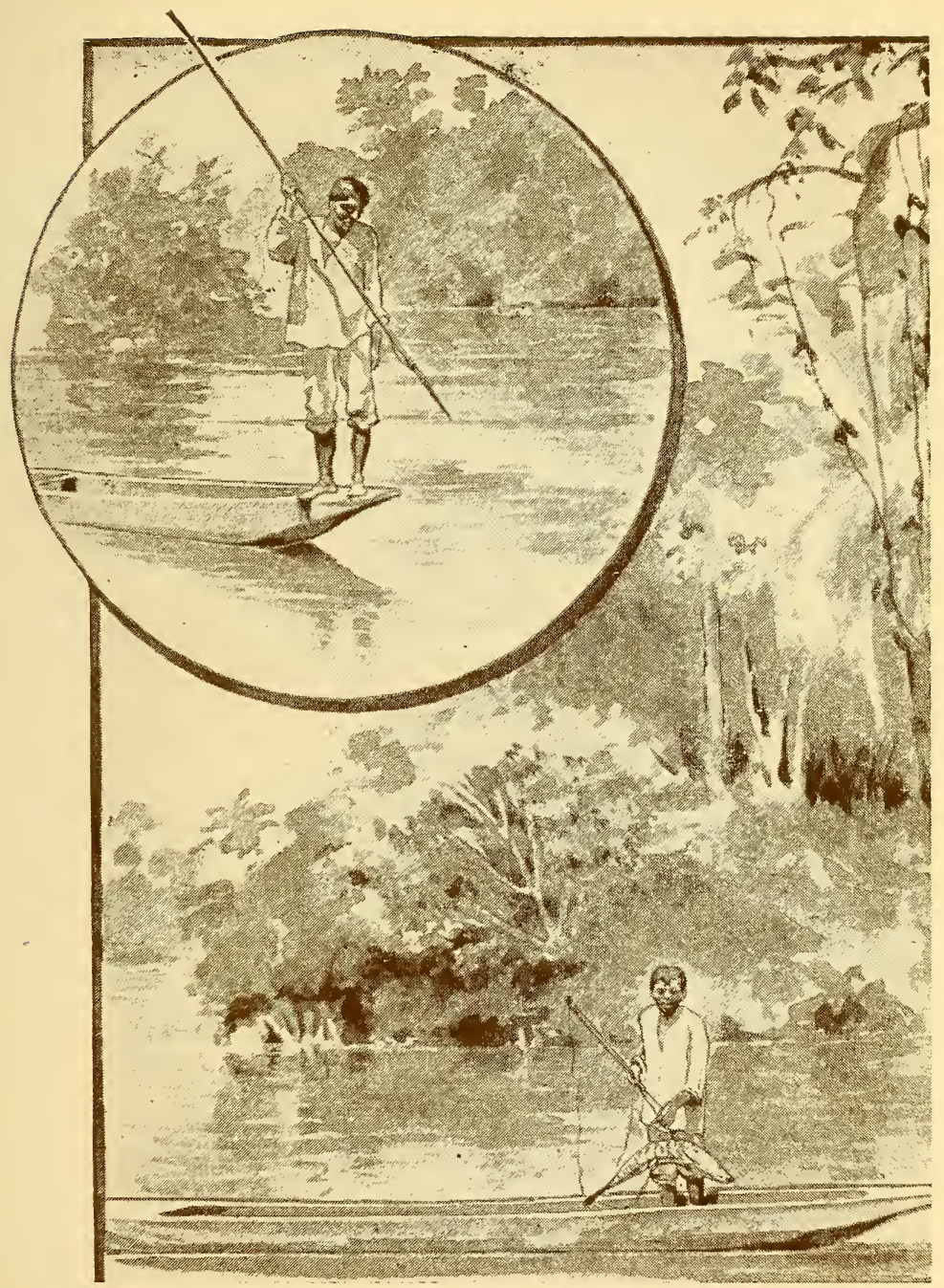





\section{A NDACROSS PANAMA}

in the deep pools of water, to the south of the swamps of the Darien region, a fish something like the sturgeon attains great size. The water is cool and fresh, and there is certainly room for such development, as the rivers in most places are very deep.

We were on our way to visit some of ine Indians, and shortly after leaving the deep pool in which the quicharos are supposed to live, we came to a collection of round houses built on long posts, according to the usage of the Choco Indians.

We found the place empty, which was a disappointment, as the houses appeared to belong to Indians of the better sort. We went on further up the river and presently came to other houses. These were also empty. Still we went on; and turning up a side river came to a large house, where the Indians had all gathered, drinking guarapo, that is, fermented sugarcane juice. The men were in all stages of intoxication, but, as my guides were well known to them, we received a welcome, and my first acquaintance with the Choco Indians began. They were a handsome people of a rather gentle appearance, using little clothing, their bodies 


\section{AROUND THE CARIBBEA N}

painted with lines representing various devices; their hair arranged in a cue, a small bunch of flowers, sweet-smelling gums, barks, or leaves tied in the end. These they sniffed at frequently, putting the end of the cue to their nostrils, and seemed to thoroughly enjoy it.

It was raining when we came up, and I must admit that $I$ was rather dirty, while my face, between hot sun and alternate rains and fogs, was burnt and blistered to all sorts of colours, and $I$ was just considering whether it would be better to do something to improve my appearance, and, by braving the rain, make myself partially clean and all wet, or to remain all dirty and partially dry, when the Indians began gathering around me.

Presently an old chief said, "I hope you don't mind that we look at you, Señor."

"Not at all," said I; "why do you want to look at me?"

"Because we never saw a man like you," the chief replied, and the others grunted an assent.

"But there have been white men through here before," I said.

"Yes, but never like you; you are perfectly beautiful," answered the chief. 


\section{ANDACROSS PANAMA}

Now an Indian says exactly what he means and means what he says, and I began to wish I had taken to the river to make myself a little more presentable, in spite of the rain.

Then the chief said, very respectfully, "You would perhaps tell us one thing, just one question."

"Certainly," I said, with pride, "what is it?"

"Do you paint, or is the colour real?"

"What colour?" I asked.

"Why, your nose, Señor; it is perfectly grand; we never saw such a colour on any man before."

I looked the other way, and then went out to see how hard it was raining, fully convinced that an Indian is a fool by nature, and that nothing can make him different.

The next day I determined to go further up the river, the Mombaramombarado, by which we were stopping, and make a general examination as I went. I told my man, Profanio, what I wanted.

"Rather dangerous," he said; "you had better not try it; but, if you wish it, I am ready." "I do wish it," I said.

193 


\section{AROUND THE CARIBBEAN}

"Then I will fix the boat at once. We can take one of the Indians, and when he says it is time to come back, we must."

"Very well, I will leave that to you, but I wish to go as far as possible," I answered. Without any more words we started. The river certainly was rough, and a number of times I thought we had reached the limit, but still we pushed on; frequently the Indian hesitated, but Profanio urged him on, till at last the Indian, pointing to a black cloud up the river, said, "Rain, flood. No more! Back! Quick, too!" We went around in an instant, and sweeping down with an ever-increasing current. The river rose alarmingly, and the roaring of the rapids was constantly increasing.

The Indian said, "We will get below the big rapids before the flood is high, and we will be - " but just then the pole held by Profanio was caught between two sunken rocks, while he was pushing the boat over to a smoother place in order to avoid a dangerous rapid. The force of the current was such, as the boat jammed against the pole, that Profanio turned a somersault over into the deepest rapid, and the Indian went head over heels backward. The 


\section{AND ACROSS PANAMA}

canoe gave a great lurch, filled with water, and almost turned over, and then, sinking like a water-logged timber, swung around and started on a mad rush down the rapids, I clinging to my seat keeping the canoe right side up, though it was entirely under water. Another instant and I would have been swept into the heaviest rapids, but just then a large, black hand rose out of the boiling water, a second it struggled, partially sank, the muscles tightened in a final effort, and my man's head rose out of the water. He caught the side of the boat and then, with an exhibition of muscular strength and skill in swimming which could scarcely be excelled, he kept the boat in position, though it was under water, and actually guided it safely down all that fierce rapid, and brought it into a quiet place, where I scrambled out on the rocks, saying, "Well, you are the greatest swimmer I ever saw."

"Yes, perhaps," he said, "but you sat still, and so it was easy enough." I really sat still because I was about paralyzed with fright; but I didn't say anything. There was no reason why I should tell him, anyway. The Indian had saved himself, and, righting the canoe, we 195 


\section{AROUND THE CARIBBEA N}

went on down the river, reached the Indian houses without further trouble, though by this time the water was well up. I had lost some valuable instruments, but had reason to be thankful that I came out of the accident alive.

We did not stop for the night with the Indians, but taking our big canoe, we were soon flying down the River Mombaramombarado, and . out into the Capa River, and on down to a Spaniard's house, where we stopped for the night.

I visited a number of places in the Choco country, accompanied by my faithful guides, but there were no further adventures, and a little later I left their country, going out by way of the Pacific. 


\section{A NDACROSS PANAMA}

\section{CHAPTER XIX.}

A CANOE ROUTE FROM THE CARIBBEAN TO THE PACIFIC

IT may not be generally known that in Western Colombia there is an almost continuous waterway available for canoe traffic from the Caribbean to the Pacific. The route is from the Gulf of Darien up the Atrato River to the Quito River, up the Quito to its headwaters, in a series of swamps and wet places, where a canoe can be forced across in rainy weather, to the headwaters of the San Pablo River, down the San Pablo to the San Juan River, and thence via the San Juan to the Pacific. This route is not always open, and on reaching the headwaters of the Quito a short portage is generally made to the San Juan River.

After my examinations in the Choco country, I travelled toward the Pacific, crossing the upper 197 


\section{AROUND THE CARIBBEAN}

divide, where the mountains are higher than those at the Quito portage, and I was some hours on the trail.

While going through the woods, one of my men suddenly cried out in pain, and said that he had been stung by a congo-ant. His arm swelled up and appeared very painful for some hours, and he told me that the sting of these ants was as bad and often as dangerous as a sting from a large scorpion. As we went through the woods, I had every opportunity of examining these ugly fellows, which are really wingless wasps.

They are black, about one to two inches long, with jaws like ordinary ants, and with these they take hold on the flesh, and then begin a regular thrashing with a long, sharp sting placed like that of a wasp, using it so vigorously that many ugly wounds are inflicted before they can be killed; at other times they keep up a running fire, going rapidly from place to place, and doing damage all the time without stopping to take hold.

They have a bad temper, and no sooner are the trees or bushes disturbed where they are living than they come swarming along the 


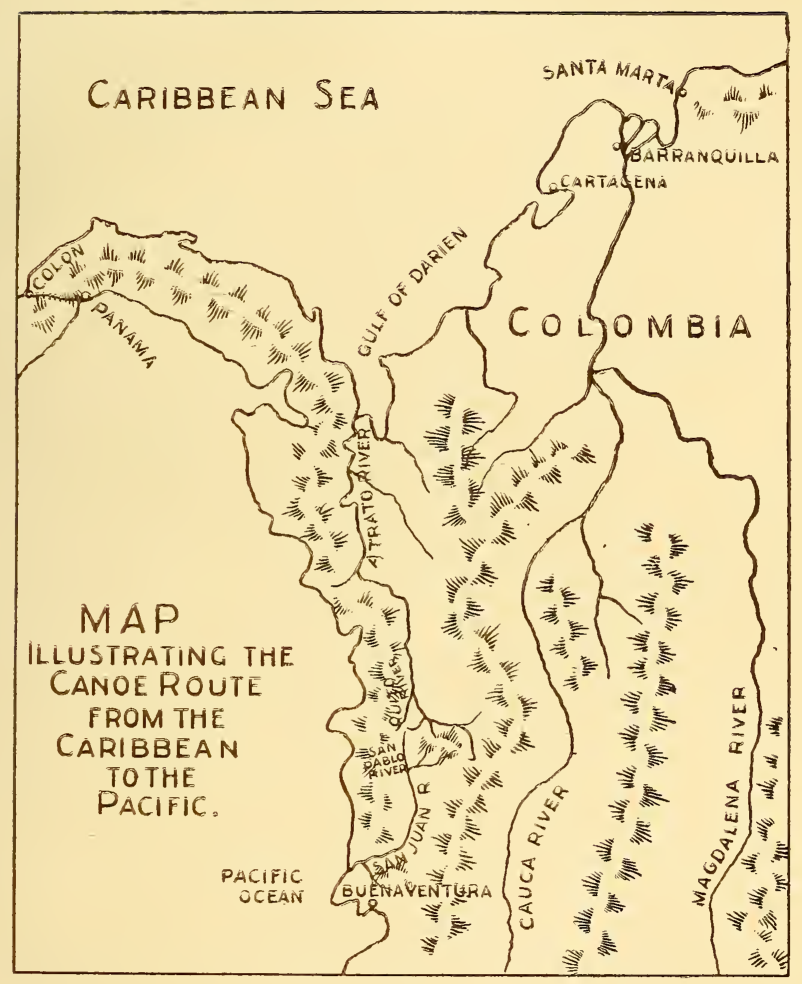





\section{ANDACROSS PANAMA}

twigs as mad as hornets, to get at whatever or whoever had stirred them up. For this habit they are much dreaded, and there are places where it is said one cannot go in the woods without being stung.

There is a smaller red ant reported in this country, called the castinette, which is said to sting harder and inflict more serious wounds than the congo-ants; but $I$ have never seen them and cannot say for myself.

We were delayed some time attending the man who had been stung, and were late reaching the canoe on the San Juan, or rather on a stream leading to the San Juan, and we could not finish our day's journey, but slept at a little village called Carmela, and early next morning started on our way again. The upper part of this river is always dangerous. It passes with great velocity through a narrow gorge, and the tumult of the waters is appalling, not a tumult of waves and breakers, for the channel is of unknown depth, but a tumult of deep, ominous sounds as the canoe goes sweeping on among the rocks. Great upheavals of water rise and fall; at times a mass of water, crowded to the surface in the narrow gorge, will pour 


\section{A ROU ND THE CARIBBEA N}

itself out over the water with frightful violence; at other points whirlpools are formed, and the surface of the river is constantly changing, but not the change of tumbling waters passing rapidly down a steep incline. The channel of the San Juan is almost at the sea-level, and but little inclined; the masses of water crowd forward as if impelled by a great force, a pressing onward rather than a falling.

As our canoe went sweeping on over these treacherous waters, we would at times feel a tremor run through it like a human shudder; then, forcing itself up all around us, would come a great upheaval of water, threatening to throw the canoe over into the seething mass. The men told me that once in that water there was no chance for escape, that one would certainly be sucked under, never to be seen again, or else would be beaten to death by the force of the waves. Once, as we were passing over a comparatively quiet place, a sudden commotion of water rose around us, and for a time the waves threatened to wreck the canoe, but skilful handling by the men saved it, and we escaped with a wetting and a severe fright. At such a time one could hardly help being overawed 


\section{A NDACROSS PANAMA}

in the presence of a mighty force so near that one could feel its every tremor.

We arrived at San Pablo without incident, and $I$ at once began looking for an opportunity to go to the Pacific. I found little prospect of starting, and secured a room, where I made preparations to stay for a few days. That night I prepared for bed, hoping that place was clean, but inwardly mistrusting my surroundings. I took my pistol and placed it within easy reach, and then lay down. How often I have done this in a strange place, and then gone quietly to sleep, not knowing when I might be awakened by some approaching danger. I have become so used to my pistol that sometimes even when at home I take it to bed with me just for companion's sake.

That night nothing happened, that is, not that $I$ was conscious of; but in the morning $I$ found myself covered with numerous red marks about two millimetres in diameter. They were filled with blood and watery matter and itched and burned considerably. It was my first experience with chinch-bugs. They are abundant in the Choco country, but I had never felt them till now. I had a full allowance and found them 201 
troublesome enough, fortunately nothing more. The bites of the chinch-bug are sometimes really serious, and frequently they inflame to ugly running sores, from which blood-poisoning has resulted.

The chinch-bug looks like an exaggerated edition of the well-known bedbug. It lives very much like the northern insect, though, being larger and stronger, wanders about more freely.

A chinch-bug lives for a considerable time, and is truly dangerous, because it carries infection from one person to another, and in a country infested with the most frightful skin diseases, with leprosy, and all the evils of hereditary afflictions, these chinch-bugs are a terror, and I have more fear of them than any of the other dangers with which a traveller in the tropics must contend.

Between the annoyance of the chinch-bugs' bites and the prospect of some days' delay, I was feeling quite miserable, when I was suddenly, most agreeably, surprised at finding that one of the merchants of San Pablo had made all arrangements for me, and that I was to start at once with a young man who was to take charge of the boat. I found him prompt and 


\section{A N D A ROS S P NAMA}

apparently efficient in carrying out the merchant's directions, so I felt satisfied that I was to be in good hands. We were soon ready, and, as there was some trouble about securing assistants, the young man said that he would take the boat on alone, rather than delay any further, and find men along the river. This sounded like good business, and off we went.

A short distance below San Pablo we came to a group of houses. The young captain of the canoe hurried on shore, as I thought, to look for men; but, to my surprise, he went to the door of the nearest house, dropped on his knees, and began to pray in a loud voice, reciting in a singsong manner some form of litany, petitioning for blessings, to which the women of the house responded, looking on him with great respect. He went to all the houses and did the same thing, then he hurried back to the canoe, looking very important, started across the river to three other houses, and went through the praying exhibition again.

This took time, and when he started for the next group of houses I protested; he paid no attention, however, but went through his prayers with great vigour, and, returning to the 203 


\section{AROUND THE CARIBBEAN}

canoe, gave me a look of mingled pity and defiance, and immediately started the canoe toward a group of houses further down the river, looking at them eagerly as he plied the paddle.

I told him that I would have no more praying, and, if he did it again, I would send him back to the merchant, and he knew what the result would be.

He seemed grieved, but I explained that I was in a great hurry and could not give him the time.

He said nothing, but, taking the boat close to shore, shouted to the people, "I can't come to pray blessings for you; the patron is not a Christian, and won't allow it."

A little farther down we stopped at a house where my man said he would look for companions. The women were at home, and I am sorry to say they were drunk, and, worse yet, my man spouted his prayers and immediately started in to drink from a plentiful supply of rum.

It was raining hard, but then it always rains in this country, and I was determined to push on; so I took the rum away from him by force, and ordered him out to look for men. He went somewhat reluctantly, but I managed to hurry him up a little by showing him my pistol, and 


\section{ANDACROSS PANAMA}

asking if he knew what it was for. He went along then, and presently came back with some young men who proved to be his brothers, and then the united families became solicitous that I should stay all night, in fact, so anxious and so curious about my things that I was satisfied that it would be better to start at once and save losses; so after considerable force and persuasion, I prevailed on the men to start that afternoon, though the females were lamenting over the loss of expected presents.

We got along well enough after this, and at nightfall stopped to sleep at a group of houses; here the young man said a lot of prayers and appeared contented. Making the best of a bad thing, I got a table to sleep on, while my men amused themselves talking with a number of canoe-owners, who, in going up or down the river, had all stopped here for the night.

I caught more chinch-bugs while I slept, and, as they were making me very uncomfortable, especially toward morning, I got the men up and made them go on.

By noon we had reached still water, and then the men lay back on their seats and began lazily to go to sleep. I angrily ordered them to go 205 


\section{AROUND THE CARIBBEAN}

on, but they paid no attention, and presently told me that they proposed to drift with the current, and we would go down the river after a time. Words seemed useless, and it would not have done any good to have killed them, for then I would have been worse off. I threatened for a time, and they began to paddle, but not for long; and presently my praying servant said, coolly, "If you will pay us more, we will work and take you to Buenaventara in good time. How much more will you add to our pay?"

" A forty-four of good lead," I replied, " if you are not careful."

They worked a little after that, but we made poor progress, and at times scarcely moved at all. It was most uncomfortable, and if I happened to want anything, the first words were, "How much are you going to advance the pay if I do it?"

In this way we went on till one afternoon I noticed that the boat stood still, and then began to move backward. I called to the men, who were sleeping on their paddles. They looked at me and then at the water and said, "The tide is rising; we have reached the sea." 


\section{A N D A CROSS PANAMA}

I was delighted, thinking that I was near the end of my journey, but I was mistaken; we turned up a river called the Colima, where we slept for a part of the night, and then pushed on to a brook called the Guineo. Here we stopped for another night, and then trouble began. The men positively refused to go on, fearing that when they reached Buenaventara they would be taken and forced into the army. There was a revolution in Colombia, and nobody knew what the outcome was to be. In vain $I$ threatened, even promising to denounce them before the Alcalde; they only replied it was better to suffer at home than be forced into the army.

There were no other men to be found anywhere, and so I had to give in and offer them increased pay; and to make it more secure, I bought each of them permission from the Alcalde to go to Buenaventara and return free from military service; and I promised to give them each five silver dollars advance on their wages if they put me in Buenaventara in one day; this they said could be done easily, and so, taking a small canoe for the trip up the Guineo, and hiring another man to be sure that 207 


\section{AROUND THE CARIBBEAN}

we could have enough to carry my things across the divide, we started on.

The brook was very low, and we had difficulty making our way around the sharp corners, under fallen logs, or along the overhanging banks. It was a wilderness of trees, plants, and coarse flowers, a typical forest of the tropical lowlands.

At last we came to the divide, and started across it, not a great distance, and, as I hired some men who happened that way to take part of my things, we made good time. We arrived about two P. M. at the hut where belated travellers stopped for the night. Here a caretaker had canoes for rent, which were needed for only half a day, and cost more than is paid for all the route I had just passed over; but then I had to have one, and the caretaker fixed the price to suit the necessity.

My men wanted to stop for the night, but I reminded them that I had agreed to pay each five dollars extra provided they put me in Buenaventara that day. They could rest, but only at their own expense.

They protested that they were tired, that the way had been long and hard, and many other 


\section{A N A CROSS PANAMA}

things. I had no sympathy, so they decided to go on. I had them this time, and how they did work and curse; it was a great satisfaction to see them, and they could work if they wanted to. They were anxious about the tide. If it were favourable, they would not have a very hard time, but we had not gone much farther down the stream when we came to a stretch of quiet water; thẹn the current began to set against us, slowly at first, but with ever-increasing strength, till presently, though we were miles away from the ocean, an irresistible flood of water came sweeping up the creek, rising, rising, till a great lake began to form among the trees around us. The men had to work now, but I cared little for them, though $I$ was well anxious about getting to Buenaventara before night set in.

We presently came out into a broad sheet of quiet water that looked black and forbidding. My men told me that it was tremendously deep, and that once in that water there was no escape, because of the multitudes of sharks.

We now began to pick our way through broad channels and between islands, where mangroves and palm-trees were growing in abundance.

The men did well here, and got through suc209 
cessfully without losing the way. To lose one's way among those islands means wandering in a labyrinth from which it would be difficult to escape.

By this time darkness was setting in, and the men said we would stop for the night at a shed made of leaves that was just beyond us.

I said we would not, and ordered them to go on. They stopped paddling and considered. I ordered them on a second time. Then one of them said, with a curse, "Let us do it now, throw him out of the boat and see the sharks eat him, and then do as we please, and have all his things, too."

"And my pistol," I said, "it is ready at my side awaiting for you."

He said nothing. "Now," I said, " go right on, or the sharks will have some dead meat presently."

They went on, and after a time we came within sight of what appeared to be the lights of Buenaventara, but as yet a long way off across the water.

Then we noticed that the lights seemed to be coming nearer, and rapidly, too. What could it mean? Then a whisper went from one to the 


\section{A N D ACROSS PANAMA}

other of my men, "A military expedition, - if they find us, we are lost."

Quick as a thought the canoe was turned to one side, the men, working now with all their might, paddling for an island that was not far away.

On came the boats below us, the lights growing brighter, yet seeming to stand still on the dark water. We gained the island and hid under the overhanging branches. Two or three boats went past us. Then the men were ready to go on again, and began paddling cautiously along the island. Presently we saw other lights, and could tell that the canoes were moving about, and that one was coming directly in toward us.

"They are searching the islands," said one of the men; "it is all up with us."

Then they made a dash over the side of the canoe for the land, and, scrambling up among the bushes, disappeared in the thick underbrush, and I was left alone, - truly a pleasant situation.

For a time I waited, expecting every minute to see a light coming cautiously around the corner, probably to be followed by a volley from

211 


\section{AROUND THE CARIBBEA N}

the muskets of the soldiers, and a demand for surrender. Most likely I would not be hit, but a searching party, expecting to meet an enemy, would, on coming across a canoe hidden under the trees, almost certainly fire, and perhaps do serious damage.

I sat there waiting, intending to call out that I was an American lost among the islands, and ask them for help, before they could fire; but it made me feel anxious, and, as I sat there, I wished heartily that whatever might be coming would come quickly. But it didn't, and after waiting for a time I called to my men, and a voice came from the woods pleading that I would be quiet, - the soldiers were on the other side of the island, and if I spoke would be on us in an instant. Then I sat waiting for a few minutes, but nothing came, and I called to my men, telling them to come at once, and, if they did not, I would fire my pistol to attract the soldiers, and when they came I would tell where to look for fugitives. A groan from the woods was the only answer. "Come now," I said, taking out my pistol and cocking it, "come, or I'll shoot."

Then I heard the men coming, and soon they 


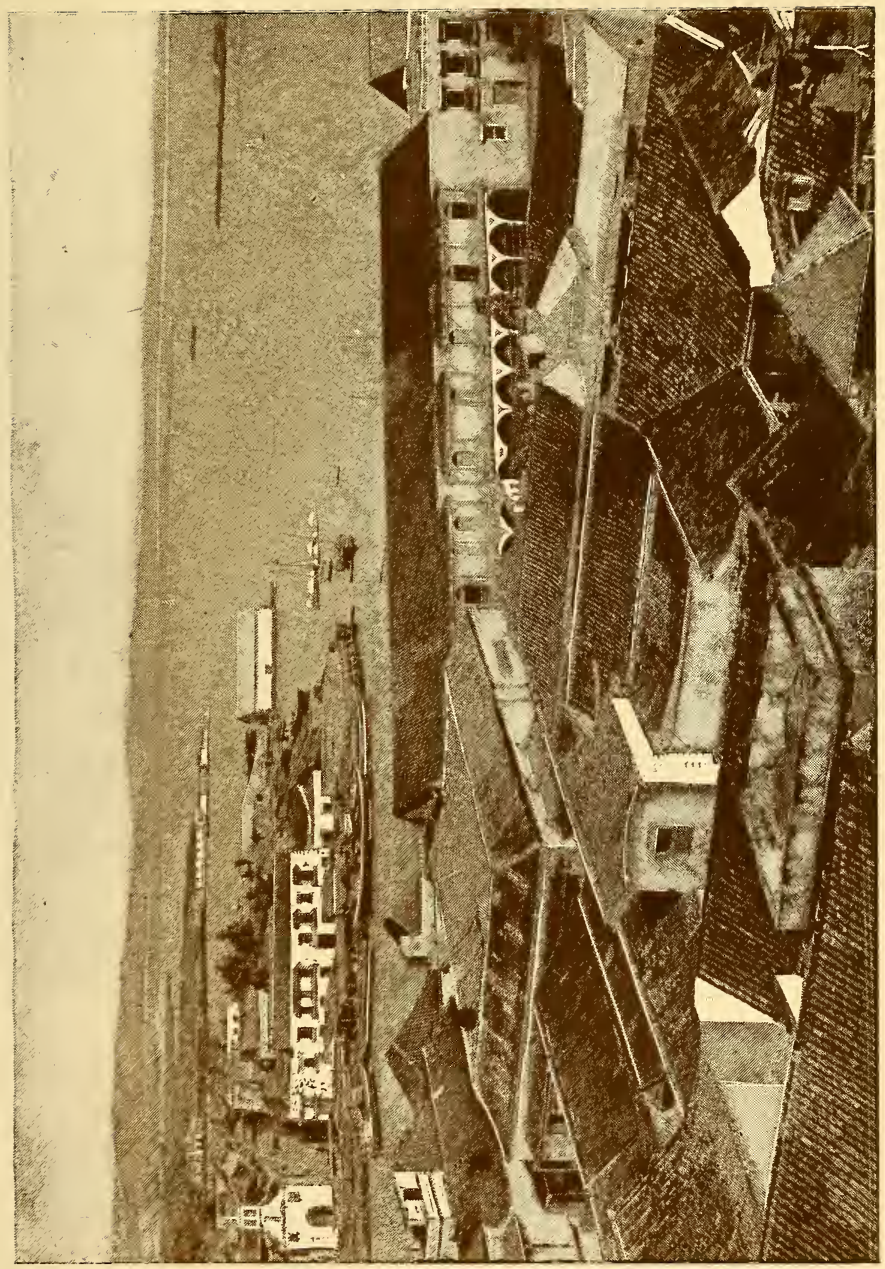





\section{ANDACROSS PANAMA}

were in the boat, with wild looks of fear and reproachful words for my cruelty. I ordered the cowards on, and we soon left the soldiers behind us. Presently we came to a brilliantly lighted house, where we stopped for the night, as it was now too late to go over to Buenaventara. The owners of the house made me welcome, and gave me a place to hang my hammock, telling me I was fortunate to have escaped the soldiers, who were out looking for a party of revolutionists supposed to be hiding among the islands.

I was fortunate in many ways. I was out of the hands of my rascally men, was in sight of Buenaventara, and just as I was getting in my hammock the rain came on, a torrent of water that was almost beyond belief, and, well satisfied that I had a roof over my head, I presently fell asleep and rested thoroughly till the morning.

I had now nothing to do but cross the bay, and reach the highway of travel again. At Buenaventara I found fair accommodations, and passed a week while waiting for a steamer.

My men were allowed to go unpunished, though I could have given them a good lesson, 213 


\section{AROUND THE CARIBBEAN}

because, when I told of my unpleasant experience, the authorities were anxious to punish them severely, but I had given my word that I would not have them punished if they took me on, and that was enough; they were allowed to go free: 


\title{
A N A CROSS PANAMA
}

\section{CHAPTER XX.}

\author{
ACROSS PANAMA
}

We drew in sight of Panama City after two days, and as we sailed into the anchorage I found that the most notable among the ships were two steamers flying the Chilian flag, attesting the progress and energy of that far-away republic, from whose shores the finest steamers at Panama had come; ships which one day or other, when the canal is opened, will be trading even to our Atlantic seaports.

The water off Panama was not very attractive, and had an uncertain colour of mud and seaweed, such as one might notice among shallow lagoons of the North. Off the harbour were groups of rather barren-looking islands, and on either side of the city the low shores of the Isthmus lay flat and uninviting. To the north 215 


\section{AROUND THE CARIB BEA N}

we saw low mountains, and to the south distant ranges of somewhat greater elevation.

When we arrived at our anchorage the tide was out, and extensive mud-flats and coral rocks barred the way to the city. After a time, the mighty flood of the tides in the Pacific turned, setting in toward the land, and presently a number of barges came out to the steamer. Our baggage was dumped into the largest with but little ceremony, and we scrambled after it, a strange company of passengers, - SpanishAmericans of good position, now tumbled and dirty from the effects of seasickness, too much depressed to care how they looked; negro labourers with their wives and children, all contented and happy, too careless to even think of their clothes; stolid Indians serving their masters, their indifference a sharp contrast to the eagerness of the others; a group of Chinese, chattering together, their excitement telling of their interest; and a number of Americans from the North, thinking they ought to be given precedence in such a company, and not getting it.

On reaching the docks we hurried out of the barges, and were immediately surrounded by 


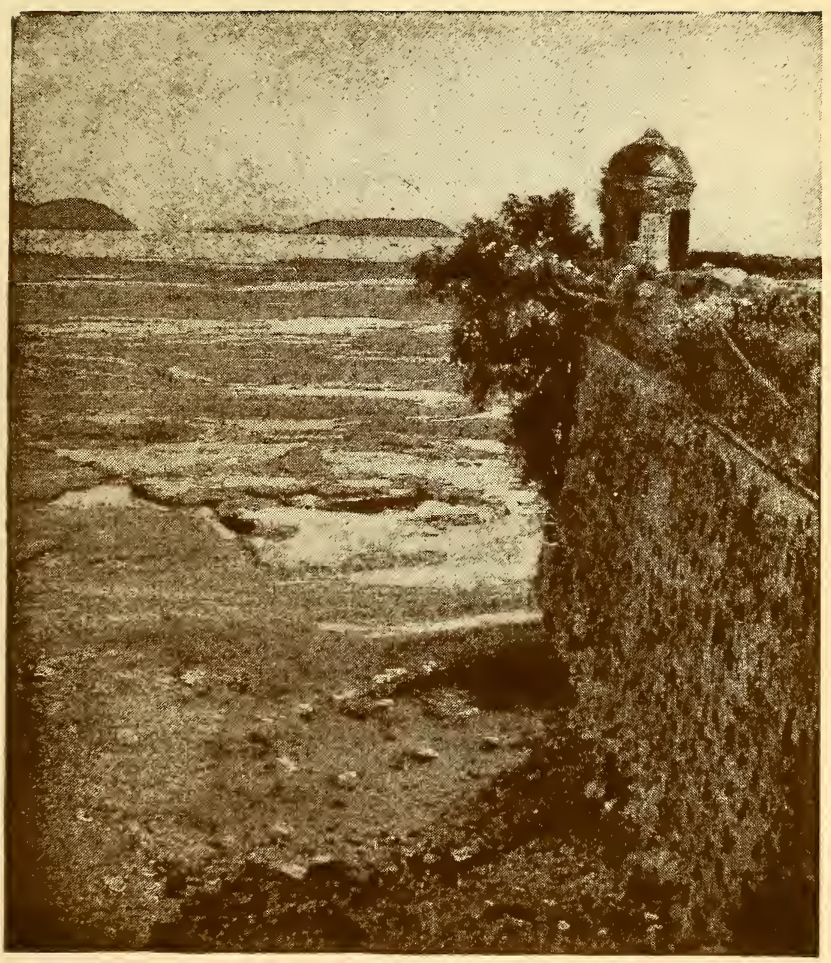





\section{A NDACROSS PANAMA}

would-be servitors. We were in the land of sharks, both water and land sharks; the Spaniards knew how to treat them, cursed the sharks, gave their baggage to their servants, and marched off. I liked that proceeding, and so cursed the sharks myself; they fell back; but I had no servant, and sat down on my baggage while the sharks looked on from a respectful distance. Then they laughed at me; so did I, - what else could be done? I was caught, and it was better to laugh than to scold. The sharks took the hint, rushed in, and the next instant a straggling parade set out for the hotel, - baggage, specimen-cases, personal effects, - all carried by a rough company of porters, while a crowd of small boys brought up the rear, struggling among themselves for the honour of carrying an old newspaper and my umbrella. It was not good for the newspaper, and my umbrella was of no further use after they had finished with it. We reached the hotel, and I paid up. When all was settled, I did not have any money to spend in Panama that night. Then a little boy came gravely in, bringing me a bit of paper, for the carriage of which from the dock to the hotel he now de217 


\section{AROUND THE CARIBBEAN}

manded payment. I gave him a trifle, to reward his splendid effrontery; he ran out, and immediately another boy appeared, he, too, bringing me a bit of newspaper. Unfortunately newspaper is plenty, and so are boys. I saw I was up against it, and fled ignominiously to my room. Panama was too much for me.

The day following I was out early, looking about the city, a place where there was not much of interest. The sun was burning hot, the air damp, and even the walls of the buildings seemed to be perspiring. I found the streets full of people, and everywhere there was a sense of activity, different from what one usually expects in a Spanish-American city. There were many little shops where curios were offered to tempt travellers; all the specimens, I was solemnly assured, came from the country, or from the ocean near Panama, the great variety attesting the diversity of the soils and the products of the Isthmus. I found cheap Mexican opals, such as I have purchased in New York at three dollars per hundred, here offered for three dollars each, and called Panama stones; there were gypsum (selenite) heads from Canada, called here country pearls; there were Indian 


\section{A NDACROSS PANAMA}

curios from Birmingham, England; fancy articles from Connecticut; in fact, material from all parts of the world, which travellers, as they hurried through the city, bought at extravagant prices, under the assurance that they were obtaining rare specimens of the varied products of the Isthmus of Panama. For myself, I did not buy, and became unpopular at once, but it was interesting to watch the shopkeepers do the travellers, and they certainly were an easy lot; but then, they wanted to secure souvenirs of Panama, and took kindly to curios from Birmingham and other places, and did not really object to paying from ten to one hundred times the value for their purchases; but then, the specimens all came from the Isthmus, at least so the travellers thought, and all were happy, even the shopkeepers.

Panama lives on the travellers; so it has been for years, so it always will be, unless the canal should be lost to the Isthmus; which all who know the disputed routes sincerely hope will not be the case, for the advantages of the Panama route are clear and convincing. But what a fine time the sharks will have when once the work is established.

219 


\section{AROUND THE CARIBBEAN}

These same sharks now gathered about me, offering all sorts of specimens, or urging unrequired services. I soon tired of it all; there was nothing of real interest in the city, so I took one of the slow trains across the Isthmus for Colon, hoping to have a good view of the canal workings. There was not much to be seen, however; only surface work had been done, though much earth had been removed, and the whole length of the canal was clearly defined, - a great ditch extending almost across the Isthmus, and at some places opened to considerable depth. Not much work was being done, though a little digging was in progress. The splendid machinery all along the route attested the millions which had been spent, and the fact that most of the machinery remained without care, exposed to the damp, destructive climate of Panama, was evidence of the careless methods which mark all that has been done on the canal up to the present time.

Crossing the Isthmus even on a slow train does not take very long. On the way there were not any attractive places, and everywhere one notices the marks of the beaten track, and surely no route is more frequented than that of 


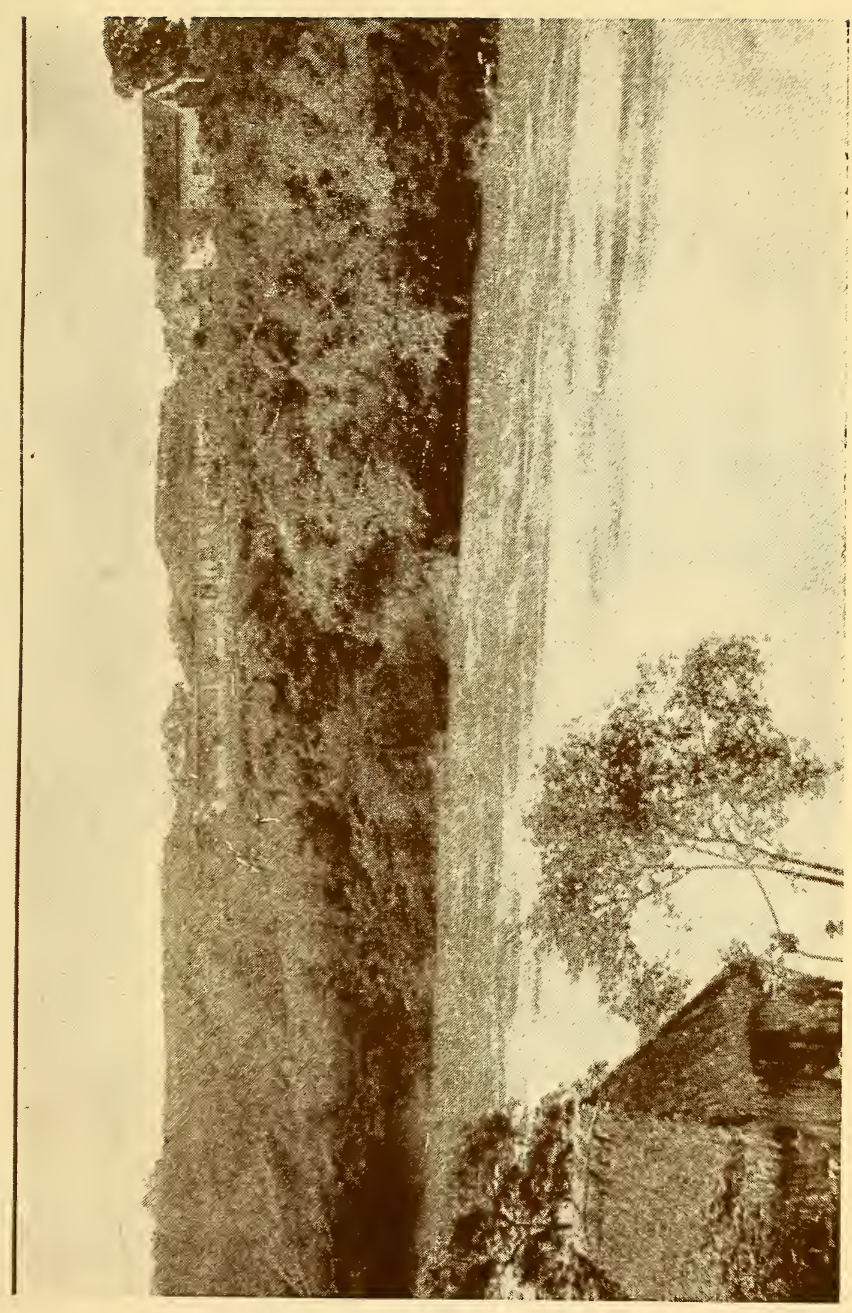





\section{ANDACROSS PANAMA}

Panama. From the car window one sees low hills, where the forests have been cut down, and the tangled growth of shrub, climbing vines, trees and palms has taken their place; a tangled, matted growth, struggling, as it were, among themselves for the mastery, the whole clinging and dragging each on the other, and not attaining the sublimity of the primeval forests of the tropics. The stations where one stops are small, and there is little of interest; the people are a patchwork of cast-off clothing, remnants of the passing crowd of travellers. There is little of real interest, and when one reaches Colon it is with a feeling of relief, for the ride has not been very comfortable, and the country has been disappointing; one has crossed Panama, but one has not seen the grandeur of the American tropics.

At Colon the question of reaching a hotel with all one's baggage, and at least a part of one's money, is of serious importance. Here the sharks are mostly black, and when I left the train they looked me over and prepared for bloodletting, but I was ready for them this time; specimen-cases and baggage were checked at the station, and I retained only three hand-bags, 221 


\section{AROUND THE CARIBBEAN}

containing what I would need during my brief stay on the Isthmus. The black men were disappointed, and urged long and earnestly the danger of leaving my effects with the railway and steamship agent; but I had some use for what silver I carried, and so left my things. I allowed a big negro to put my things on a handtruck, and take them three blocks to a hotel. I expected to stand twenty-five cents gold for each bag, a total of about two dollars and forty cents in their silver, or at the rate of some eighty cents silver per minute for his services; but on arriving at the hotel, he demanded three dollars gold, about three dollars and twenty cents per minute in his money. This did seem to be rubbing it in too hard, but I gave him half of what he claimed, and told him if he wanted the balance he should make an appeal to the Alcalde, the head magistrate of the town. This he did, with all assurance, and I had a small lawsuit on my hands, a circumstance in which I found considerable interest, for I wished to see how the baggage-sharks were treated. The Alcalde gave little heed to what I had to say; the negroes were threatening, and quite a crowd had collected, and the Alcalde was evi- 


\section{AND ACROSS PANAMA}

dently afraid of them, for he gave a hasty decision in their favour, and directed that $\mathbf{I}$ should pay the money immediately. I had given them half of what they claimed, and now offered to pay the balance, but no, they must have the whole amount which had been awarded to them; and so a second dispute arose, and I was ordered to pay the whole claim, and I did so, feeling rather indignant at this example of "justice" on the Isthmus of Panama; but I was through with the sharks, for a time at least, and now went about my own affairs.

Colon is a city of sheds and board houses. There is one main street where there are a few large stores; the city has several side streets where the houses are on stilts, and just beyond the city there are swamps, where mosquitoes reign supreme.

Bloodletting is the common practice, from the mosquitoes which infest the air to the children who seek contributions in the streets, the baggage-sharks who haunt the stations and wharves, and even to the leading merchants, who sell spurious curiosities, and smilingly do the travellers for what can be obtained. Also the watch- 


\section{AROUND THE CARIBBEA N}

ful officials, ever on the lookout for the main chance.

All this is typical of the lowlands of tropical America. In the mountain parts it is frequently different; an incident will illustrate. Once, when I was stopping at Madellin, in Colombia, a little bootblack made himself useful, and received fairly liberal tips for running errands and generally guarding my interests, as well as keeping my shoes clean. One evening, as I was going to dinner, he came running up to me, a broad smile on his face, and in his hand three cactus figs rolled up in a bit of paper. The package was thrust into my hand, and the boy started for the door, as if he were in a hurry to get away. I called him, so that I might give some little gratuity, but he only shouted back, "No, no, they are not for money; they are for you," and then he bolted out the door and was away in the streets. At dinner I was told that the fruit was really choice, and long out of season, and every one wondered that the boy had found some, saying that he must have climbed for hours among the mountains trying to obtain them. This happened in the breezy interior uplands among the mountains, where a race of 


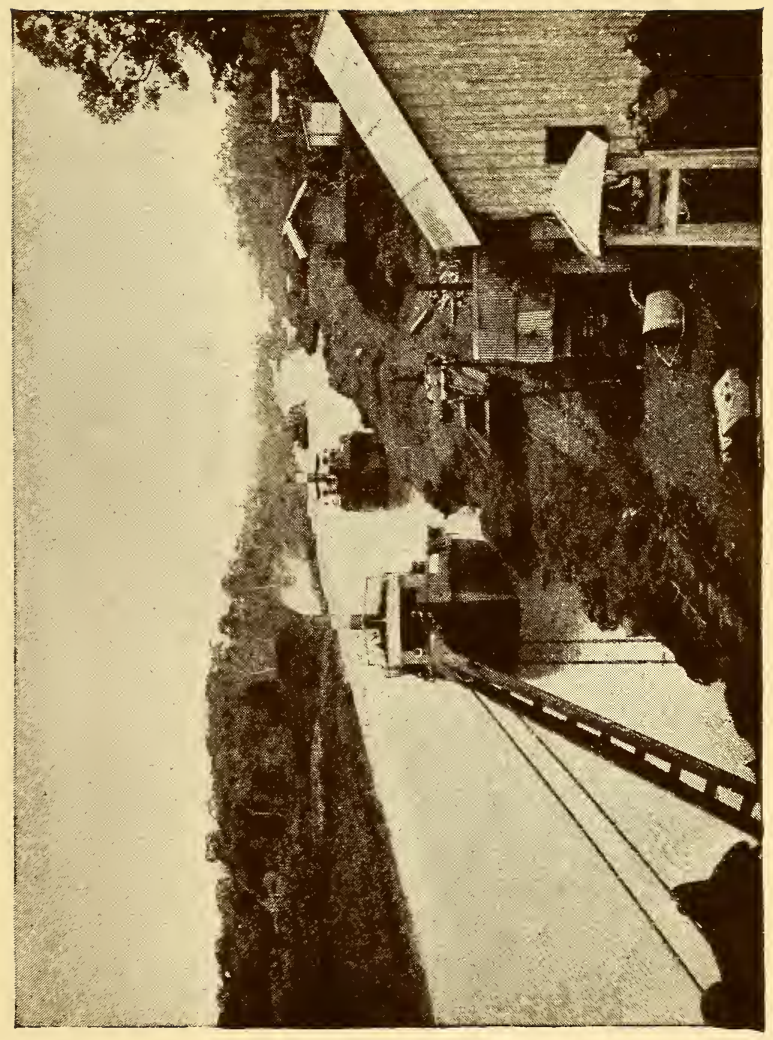





\section{ANDACROSS PANAMA}

people is growing up strong in body, of healthy morals, an honour to themselves now, and who will one day become a power in the world. They are different indeed from the cringing, swindling, unhealthy, mixed-breed weaklings of the lowlands, people who cause our ideas to be somewhat unfavourable in regard to everything Spanish-American.

Here at Colon I found the usual population of the coast, their dispositions somewhat more unpleasant than usual, with their clutch at one's purse-strings for ever grasping and impulsive. 


\section{CHAPTER XXI.}

THE INDIANS AND RESOURCES OF PANAMA

I Found at Panama a rich country, where agricultural opportunities are attractive and mineral wealth is abundant.

Panama is everywhere accessible to the water, and as a consequence the principal roads are to the coast, and little trading-ships are numerous, for the ways of communication are principally by water. Wherever a stream is found available for canoes, they are used, though, except on the Silsola River, on the northern boundary, and on the streams about the Chiriqui Lagoon, there is but little canoe travel.

Panama is reputed the most unhealthy of all places in the American tropics, a natural inference because the route of travel has sought the lowest divide for crossing the Isthmus, and low lands in the tropics are unhealthy; particularly 


\section{ANDACROSS PANAMA}

where there are swamps, as at Colon, and great exposures of marine drift when the tide falls, as at Panama City. These places are unhealthy, and their reputation is well deserved, but after leaving the depressions between the two seaports one finds a better country, where the lands are rich, and the climate reasonably favourable. The Chiriqui Lagoon is considered a health resort, and among the interior mountains I have found many desirable regions, though the elevations are rather abrupt, because the rock formations disintegrate easily, and erosion has been rapid; hence one finds steep mountainsides, deep valleys, coastal plains of eroded material, and swamps. Among the mountains the air is temperate, and all the surroundings delightful. In the deep valleys there is intense heat and poisoned air. On the coastal plains, wherever there is good drainage and an open sweep of the trade-winds, the climate is delightful, though hot, and the lands are desirable. In the swamps, no man can live.

In the northern portions of the Isthmus there are mountains of considerable elevation. Southward these gradually subside to the central depressions where the canal is being seriously 


\section{AROUND THE CARIB BEA N}

considered. Farther south the mountains rise again and become very prominent. If the canal goes to Panama, the Isthmus will enjoy some. years of active construction, with large expenditures of money, followed by a great commercial movement. Lands along the central depressions are good and fertile, but the climate is undesirable. To the south the inhospitable San Blas Indians are a dangerous element, so it appears that the lands most desirable for foreigners are in the northeastern part of the Isthmus, and that Boeus del Toro and the Chiriqui Lagoon regions will be the places from which supplies to feed the canal labourers will be principally drawn; though there will be a strong rival some distance to the eastward in the Sierra Nevada de Santa Marta Mountains, also a portion of Colombia; for there everything can be grown, even the products of the temperate regions of the north, and from there vessels once loaded can run directly before the trade-winds into Colon; but of the lands on the Isthmus, those of the northeast seem to me the most desirable, and I have written of them because it may be that presently many will be going south, and a word in time may be valuable. Coastal plains, where the 


\section{ANDACROSS PANAMA}

drainage is good, and the winds blow freely, are desirable; mountainsides, so situated that products can be easily carried to the sea, are almost sure to provide a favourable basis for development; but of the coastal plains where water is stagnant and the trade-winds are weak, of the rich alluvials bordering on swamps, and of the deep, hot valleys, beware, - even the Indians avoid them.

Of all that I saw in northeastern Panama, the primeval tropical forests at the base of the mountains were most impressive. There one steps from a canoe to the shore, pushes aside a rank growth of reeds and plants, struggles through them for a little distance, reaches a wall of green foliage, lifts an overhanging bough, scrambles under, and the world is shut out; the traveller stands in shadow-land and silence. Strange, dim butterflies go wavering in and out among a dense growth of ferns and tender plants which could not endure the sun, giant trees form as it were columns for an expansive roof of green, and everywhere the gray trunks of slender trees reach upward till their branches find the sunlight far above, and their naked stems seem like a slender tracery pendant 229 


\section{AROU N D THE CARIB BEAN}

from the upper roof of green. A tangled, matted growth it is, climbing vines festooned among the trees, deep shadows, here and there a bit of glowing sunlight, and mysterious depths ever opening out as one presses forward. Such are the primeval forests of the tropics, and nowhere can they be seen to better advantage than at northeastern Panama.

That the Isthmus has many desirable places is evidenced by the Indian tribes who have long made it their chosen home. In the north there are the Chiriqui tribes, Indians who make pottery and have better methods in their system of living than many of the Central American tribes. In the mountains of the interior there are other Indians, who much resemble the Talamanca people of Costa Rica, but who are at bitter enmity with them. My visits to the country occupied by these Indians were not long enough to learn much of their customs. In appearance, they have a general resemblance to the Indian races found through Central America, from the coastal plains and forests of Honduras, southward to the depression of hills, and to the swamps and lowlands between Colon and Panama. 


\section{AND ACROSS PANAMA}

South of this depression are the San Blas Indians, with whom my acquaintance is also limited. Their appearance indicates a race different from the Indians living along the coast farther north. The San Blas men have stronger features and more character in their faces. Traders who have frequently been along their coast tell me that their morals and methods of living are a credit to them, and I was told that their word in a trade was good even to their own disadvantage. Once given, their word would not be broken.

I was told that their chief had stated, when talking of their tribal legends, that white men and gold were the two curses of the Indians, and because of them their ancestors had long ago come as fugitives across the deadly swamps to the south, and had settled among their isolated mountains where neither white men nor gold could come.

I was told that the chief had said that formerly they were a great people, and that their two principal cities were called Quito and Caracas, and that between those cities there had been a great country inhabited by many Indians, and there was much gold. Then the 231 


\section{AROUND THE CARIBBEA N}

white men came, and the gold brought trouble, and finally his ancestors went away, crossing the mountains, swamps, and rivers, till they should find a country so far distant that the white enemy could not find them, and wherc gold could not be had. This is a legend. I did not hear it from the Indians myself; but several traders corroborated the story, and all attested the strange determination by which the San Blas Indians maintain that death is preferable to the presence of white strangers. One thing is certain, no white man can live in the San Blas country. These Indians will trade any of their products, so long as the traders sleep in their ships, and come ashore only when invited; but let the trader speak of gold, and they will all leave, assuring the trader that there is none in their country, and that he had better go somewhere else.

Little is known of the San Blas country, and it is said that their mountains are rich in gold and that other minerals are abundant. This is more than probable, for those mountains are directly in the line of the chain of gold deposits, which, beginning in Alaska, continue southward, through California, across Mexico, Central 


\section{A NDACROSS PANAMA}

America, and Panama, and thence on southward far away into the Andean ranges. Yet it is probable that the legends of gold in the San Blas country are exaggerated, for exaggeration has always an undisputed field where the country is unknown.

It is related that a party of Colombians from Cartagena, attracted by the rich agricultural lands of the San Blas country, started a colony there, settling on the shores of a convenient harbour on the Atlantic side of the Isthmus; but on the first night, bands of Indians attacked them, and killed all but one, who, after being tortured, was sent back to Cartagena with his ears cut off, as an example to all who thought of visiting the San Blas country. The story continues that the government of Colombia sent soldiers to chastise the Indians, but the soldiers too were killed, except one who was captured, and who, after being tortured, was sent with his ears cut off as a present to the President of Colombia, with a warning that so all his soldiers would be treated if they came to the San Blas country.

This was long ago, and since then that country and its Indians have been left to their own devices. Along the San Blas coast there are 


\section{AROUND THE CARIBBEAN}

numerous islands where the finest cocoanuts are grown, forming the principal article of commerce sought by the traders who visit that country.

When I saw these islands, I was simply sailing past them, for the Indians were not friendly to a complete stranger, and it was thought best not to stop. I was much impressed with the productiveness of those islands, and the lands beyond them looked attractive, but between the Indians of that country and white men is a barrier, and I have no information of what may be hidden behind their cocoanut plantations and the islands along their coast. 


\section{AND ACROSS PANAMA}

\section{CHAPTER XXII.}

PANAMA AND NICARAgUA ROUTES FOR THE ISTHMIAN CANAL

While crossing the Isthmus of Panama I became thoroughly convinced that this was the most favourable route for a canal. One easily obtains such an impression from the proximity of the two oceans, for at Panama the extremes of the world meet at a narrow divide. The Pacific Ocean ebbs and flows, piling up a mighty tide of waters, rising and rising, a flood that comes as if there were to be no ending, at some places even turning fresh-water rivers backward on their course for miles inland; and then the tide subsiding, a mighty rush of waters turns again to the ocean; nor is the outward flow checked till great stretches of mud and rock are uncovered, where but a short time before had been water deep enough for vessels to sail 235 


\section{AROUND THE CARIBBEAN}

undisturbed. On the other side of the Isthmus are the waters of the Caribbean, where the tides are scarcely noticed, and the appearances are as different as the waters of one side of the earth can be from the waters of the other side.

At Nicaragua these conditions are not so impressive, for between the shifting sands at Graytown and the Pacific there is a large stretch of country, a route of travel occupying some days, so that one is impressed with difficulties and distances, and wonders at the engineering skill which could plan a waterway to accommodate ocean-going vessels for so great a distance; but travelling between Colon and Panama one sees the two oceans within a few hours, and feels how close one is to the other, and thinks how natural that a canal should be planned to cut the hills which separate them.

Once when I was making some examinations on the borderlands of Costa Rica and Nicaragua, I stood on an elevated ridge where I could see all the proposed route for the eastern portion of the Nicaragua Canal. I saw before me a vast stretch of country, treacherous lowlands such as I have learned to dread, and I imagined the strange appearance a great ship 

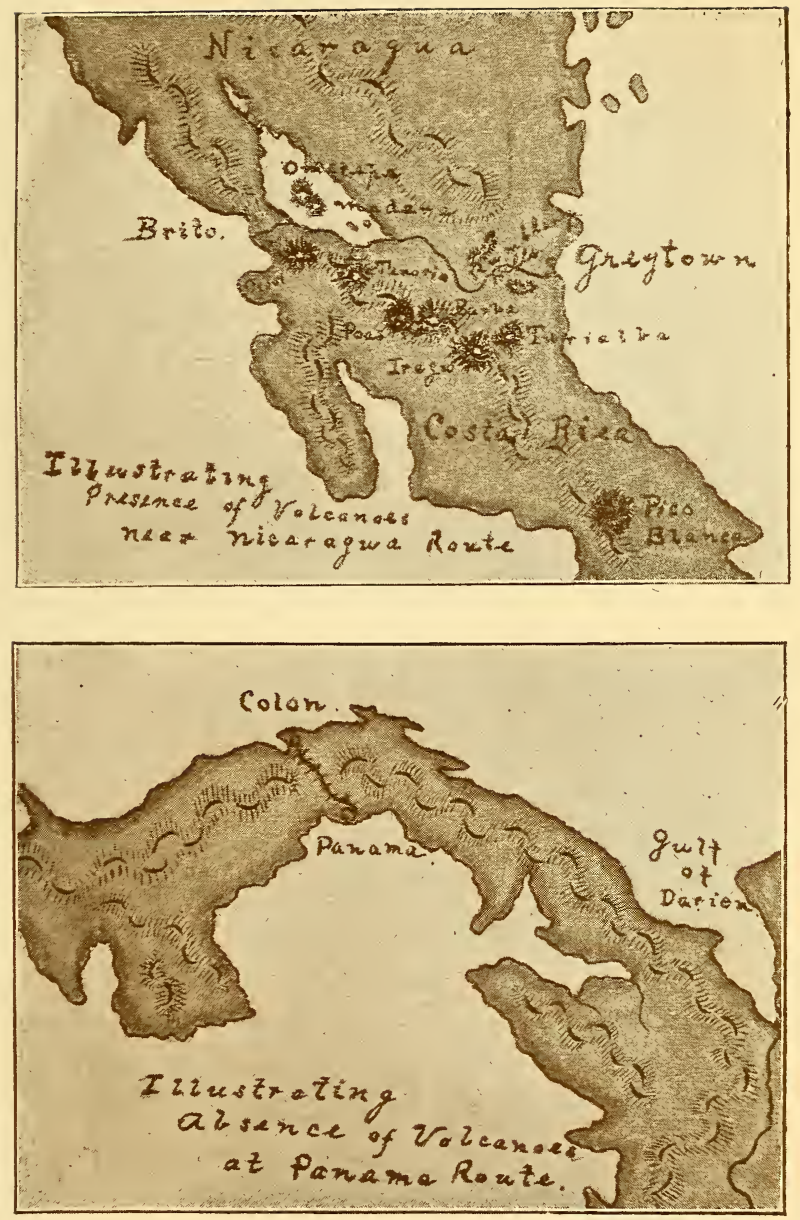



\section{ANDACROSS PANAMA}

would make, passing on among the dense woodlands, should the canal be constructed over that route, and I could not but think of the cost of maintenance. I have had to deal with the problem so frequently in the tropics, where earthworks do not resist as they do at the North; and I wondered how many times the banks of the canal would be washed down in such a country by the sudden floods which come so often in the tropics, and from where I stood it seemed that all the water of that great basin would wash toward the proposed canal route. And I wondered if a great dam could be continuously maintained, for the soil is eroded of recent material from the surrounding volcanic ranges, and is lightly packed. The proposed lake would cover a great area, and at places its banks would be little more than low divides, which, it seemed to me, would afford but unstable retaining powers where floods would chafe to find an outlet. The soil is easily eroded, and the fierce storms, all too frequent in that country, might readily supply the force, and at some unexpected point erosion might form an outlet, and suddenly the waters of the lake might subside, doing incalculable harm.

237 


\section{AROUND THE CARIBBEAN}

Nor is maintenance the only difficulty, and surely the Panama route has its share of maintenance problems, only the problems do not continue over so great a distance as at Nicaragua. There are shifting sands at Graytown, but at Colon there is quiet water. At Graytown there is the full force of the waves which are continually washing against the shore. What a serious impediment to navigation, and what wrecks will strew that shore if the canal goes to Nicaragua, for the entrance could be but comparatively narrow; surely a ship would require skilful handling to make safe entrance during rough weather. At Colon a rowboat could go safely on a pleasant excursion in and out of the canal entrance.

Graytown has one advantage, a great advantage over Colon, it is among the healthiest of places in the tropics, because it is built on a series of sand deposits, which have been formed seaward one after the other, and the place is open to the full sweep of the trade-winds; but back of Graytown is a swampy country extending a long distance inland. Advocates of the Nicaragua route contend that these swamps are healthful, but I have never seen a healthful 


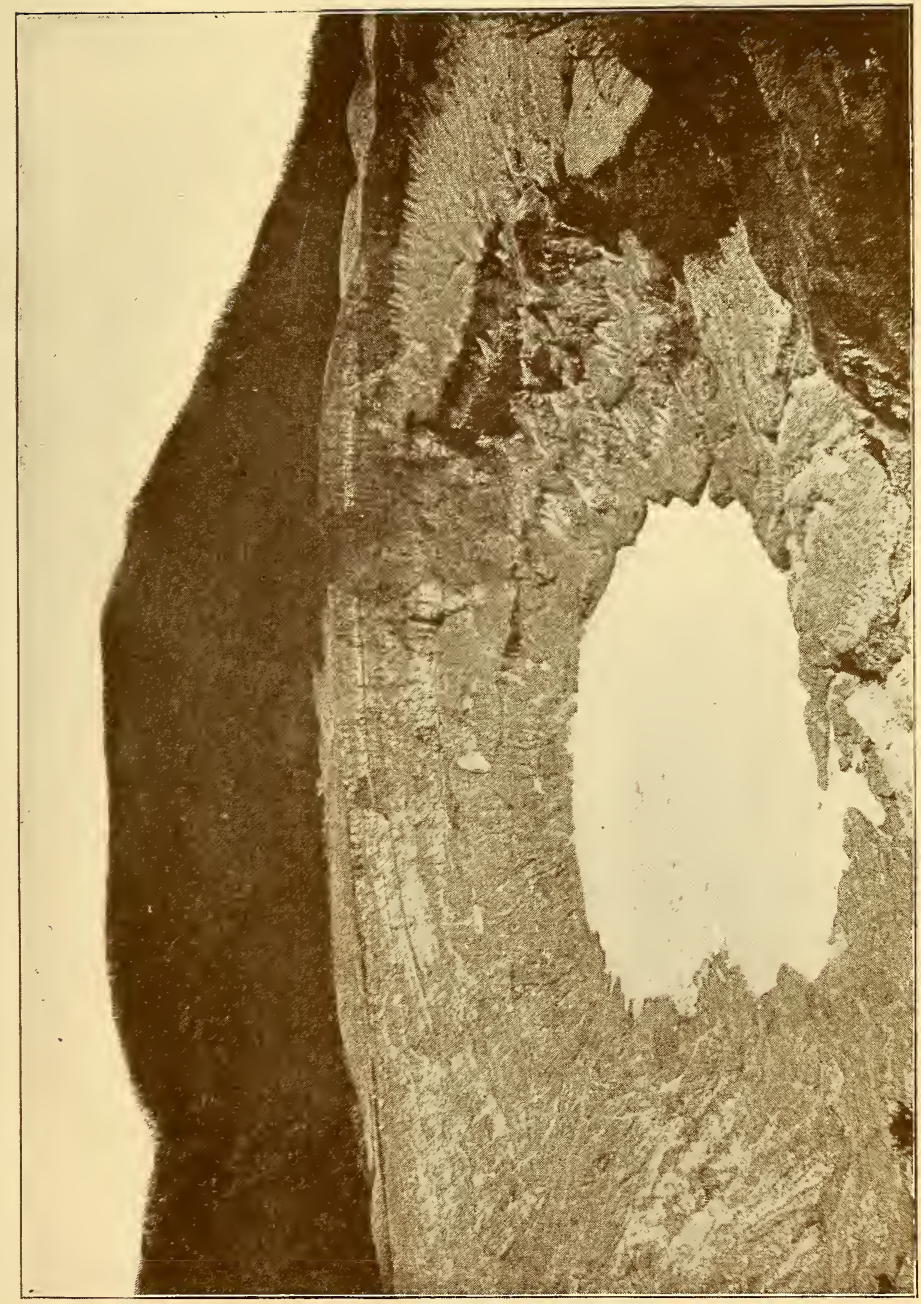





\section{A NDACROSS PANAMA}

swamp in the tropics, and I have seen a goodly number of them; one can live in such regions for a time, but once let extensive excavations be undertaken, and the swamps will give an account of themselves. There is another serious question to be considered in regard to the Nicaragua route: it lies between two ranges of mountains where there are volcanoes, dormant it is true, but still giving indications ominous of what might be. In Costa Rica, one called Poas at the western end of the range is still steaming. In the crater of another, Irazu, directly overshadowing the proposed route, water has risen up and disappeared again, an instance carefully explained by my guide when $\mathrm{I}$ ascended that mountain, and spent some time examining the crater. Across the broad valley the ancient volcanoes of Nicaragua are all dormant, but frequently mysterious rumblings are heard among them. Can any one say surely that these volcanoes are dead?

As I stood looking across the eastern portion of the proposed Nicaragua route, I felt a slight tremor under my feet, so slight it might have been only a fancy, then came a faint rumbling, 239 
and my guide said, "Hear the Nicaragua mountains growling at us. A storm is coming."

I asked him if this sign was sure, and he said that when rumbling sounds came from the mountains in Nicaragua a storm could be expected, that they did growl sometimes in dry weather, but they usually made the most noise when the rainy season first began, so people associated them with rain. Surely those are ominous features, and one's spirit trembles at the thought of what might be, should those volcanoes again become active. In Costa Rica is a range of volcanoes, one of which at the extreme western elevation is still steaming, the others standing like gaunt sentinels, their cinder cones raised high in the air, barren and desolate, overlooking a broad valley; and on the northern side of this valley is a series of mountains from among which rumbling sounds come so frequently that people living along the southern edge of the valley listen with indifference, remarking only that rain is coming; and through this valley the construction of a great interoceanic canal has been seriously, and even earnestly advocated.

I was so deeply impressed with the difficulties 


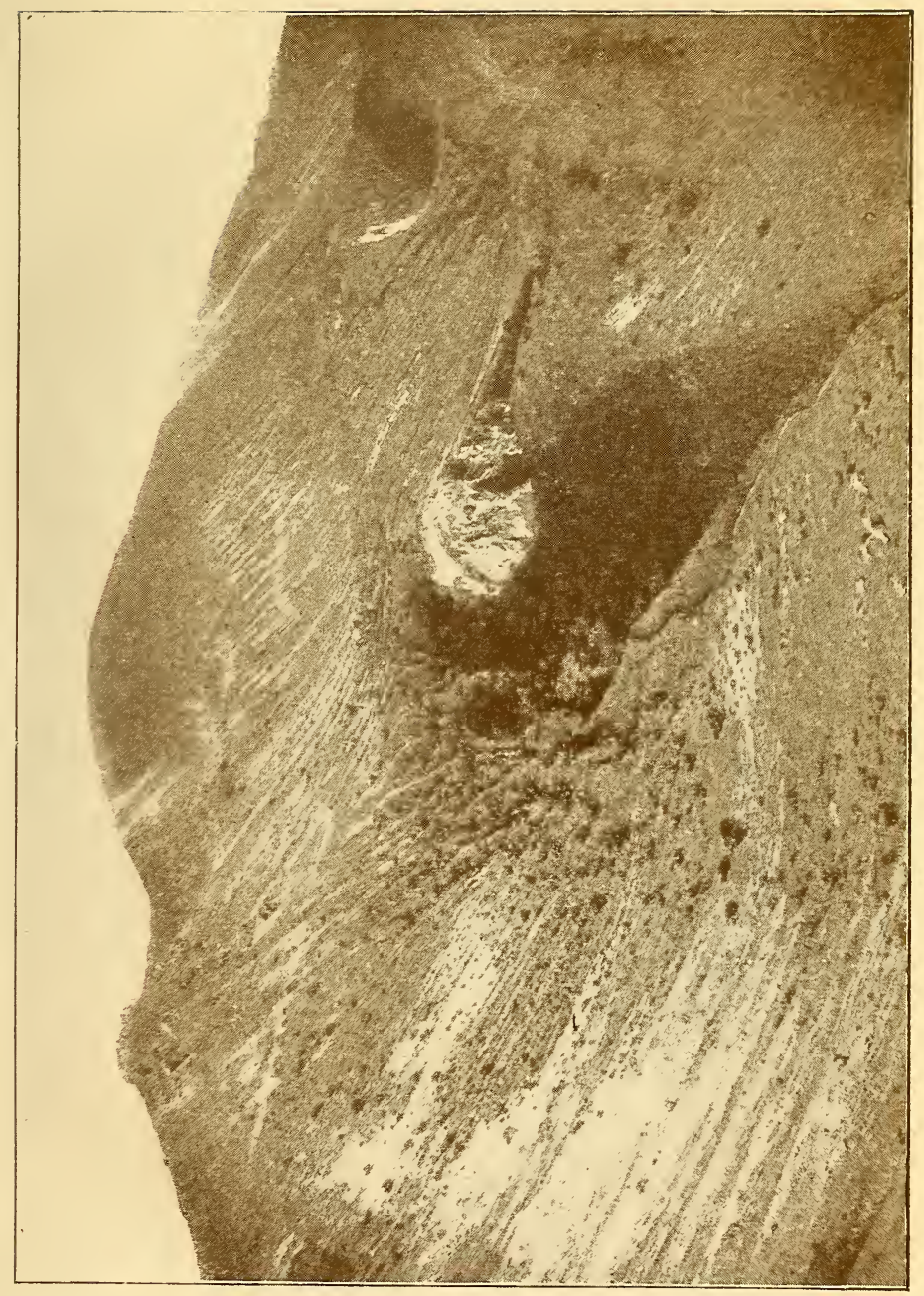





\section{A N D A ROS PANAMA}

and dangers of the Nicaragua route that I said to friends, on returning to the coast, that no canal would be built at Nicaragua until the political difficulties which stood in the way of a reasonable treaty with Colombia had been considered in all their features, and were found to make it impossible that a canal should be undertaken at the Panama route.

In Colon I was asked for my opinion over and over again, for at the time of my visit it looked as though the Nicaragua route would be selected for this great enterprise; and when I went away, common report had it that in Nicaragua there was a valley of fire surrounded with blazing volcanoes, and that I had seen it, - a good example of Spanish-American exaggeration. 


\section{AROUND THE CARIBBEAN}

\section{CHAPTER XXIII.}

\section{HUNTING FOR GOLD IN ANTIOQUIA}

From Colon I took a steamer bound for Savenilla, the seaport of Barranquilla, Colombia, where $I$ arrived in two or three days, and immediately began preparations for a journey to the gold regions of Antioquia.

I found Barranquilla a city of activity, sand, dust, fleas, and pretensions; but for all that, it is one of the coming places in Spanish America, and has so much to expect from the future that it would be difficult to set a limit to the growth and development which may be here expected ; for all the great waterways of Colombia lead to this city near the mouth of the Magdalena. After a few days at Barranquilla, I took passage on one of the numerous river steamers, and was presently making my way up the muddy waters of the Magdalena. The steamer was crowded, the day burning hot, and 


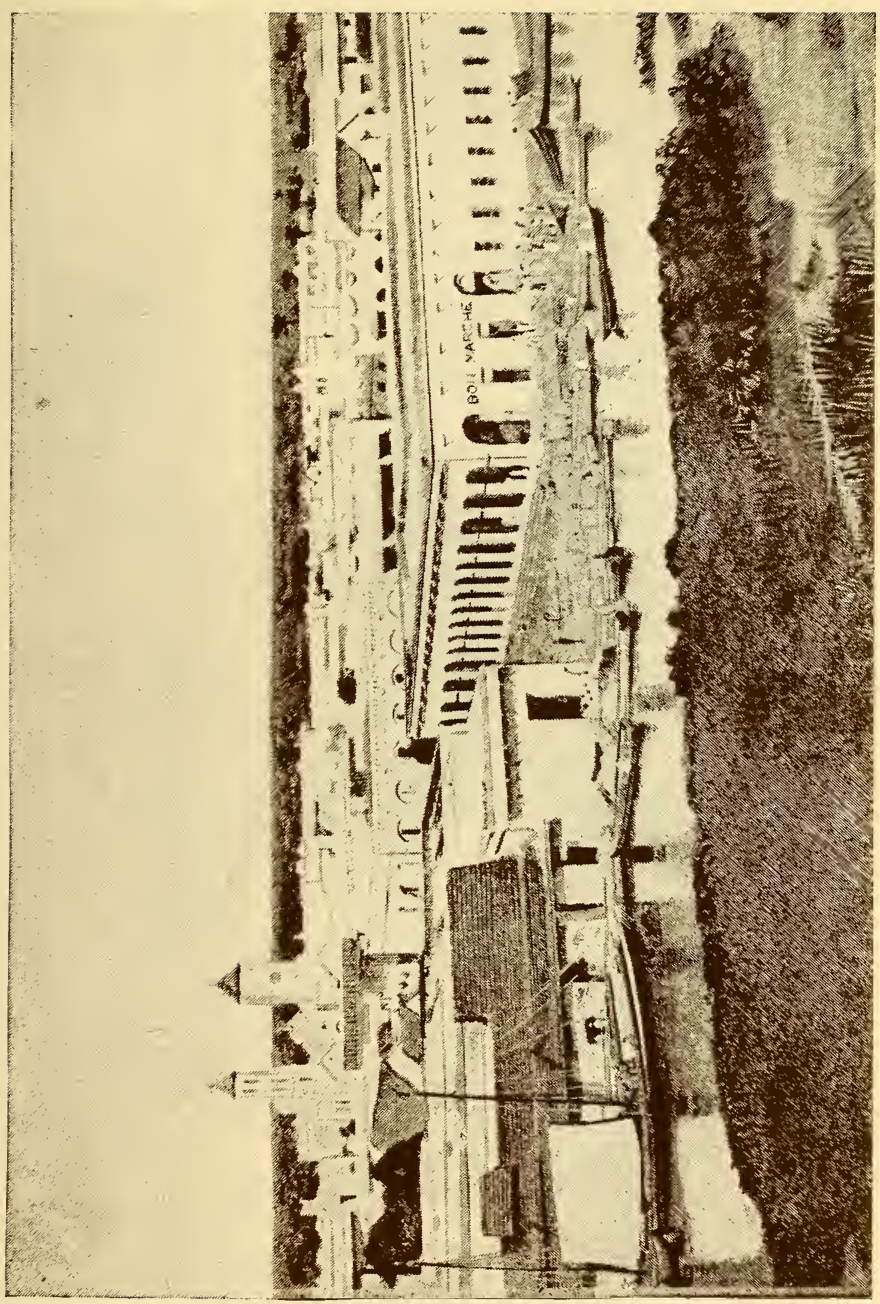





\section{AND ACROSS PANAMA}

the succession of monotonous appearing swamps and low meadows was most uninteresting. Mudbanks, sand-bars, and dead trees were frequently passed; alligators, herons, and aquatic birds were in abundance; and on either side of the river the lowlands, swamps, and lagoons spread out for miles. A most unhealthful region, where foreigners can hardly expect to find lands suited to them, though many people native to these lowlands do well in this country. After a few days' travelling, the steamer reached Puerto Barrio, and there I left her to take the road overland to Madellen, and on this road I found inconveniences abundantly, in some places even sorrows, for the chinch-bug was ever present, and the nights were passed as a delirium rather than as a time of rest and sleep.

This was Antioquia, a region endowed by every resource of nature, from mineral wealth to agricultural products. The people in the uplands are a strong, vigorous race, fine-looking and intelligent, but shrewd and rather hard in their dealings. The mountainsides and fertile valleys of their country are well occupied, and most of the best places are taken up. Travelling on their principal road to the capital, Ma243 


\section{AROUND THE CARIBBEA N}

dellen, one passes over the mountain ridges, follow then the road into deep, rich valleys, where all the surroundings are a delight to the eye; but at night, when one stops at the roadhouses, there are chinch-bugs and torture. I will never forget a night when a travelling companion took me to one of the smallest of these places, where all the family worked, ate, and slept in a single room; here he sat up nearly all the night talking boisterously, and a group of women at one side of the room told their beads continuously, a singsong drone varied with long, loud petitions for material benefits. Apparently they proposed to keep on praying all the night, and the chinch-bugs in droves and hosts came attacking me as I lay helpless on a rough bed, finding sleep impossible, and wondering why I could have been such a fool as to come to the tropics. There was no sleep that night, and when morning came I was a mass of blistering bites and blood-marks from the attacks of the chinch-bugs, and found myself in a state of irritated fever. Fortunately I reached Madellen that day, and found better quarters, where, under the influence of fine air and clean food, I was soon myself again. 


\section{A NDACROSS PANAMA}

I stopped for a time in the city, making various excursions from there to examine mines in different places, among them the strange, deep valleys where rivers have eroded almost to sealevel, bringing, all the while, gold-dust down from the surrounding mountains, to be collected in the low valleys, where the streams at flood overflow their banks, and then quickly subside again, leaving behind them mud and decaying vegetable material to fester in the sun. This poisons the air to such an extent that none can remain in those valleys without contracting dangerous fevers.

After attending to such matters as claimed my attention at Madellen, I engaged mules, and with a guide started over the mountains for a place called Zaragoza. At first all went well, then one day I was attacked with a violent fever, such as I had never known. I stopped at a road-house, where good fortune followed me; the place was clean, and was presided over by a kind woman, who, seeing my condition, gave me every attention, in fact, better care I could not have had; but in spite of her efforts the fever kept mounting higher; such remedies as I had were of no avail, and matters were be245 


\section{AROUND THE CARIB BEAN}

coming serious. Medical aid could not be had except by sending miles away, and grave faces were gathered about me, when, to the surprise of everybody, one of the most noted physicians of Madellen came passing that way, a providential aid for me; he came just at the critical hour, passing the house where I lay, on his road to visit a coffee plantation he owned, not having seen or been that way since two years, and now visiting it for the last time, for he intended never to come again. My good hostess ran eagerly to call him, and as he came in the room I realized I was to be in good hands. A hurried examination, and he sent my man galloping away for medicines, and in about two hours I was being put through a course of heroic treatment, - first, emetics for two hours, during which I drank quarts of water to assist the action; after this there was a course of purging, so violent that it seemed scarcely endurable, but the treatment effected a cure, and the next day I was told that I had suffered an attack of malignant fever, a malady so dangerous that it frequently kills in twelve to twenty-four hours. Truly the physician had come only just in time. After a day or two, I resumed my journey, and 


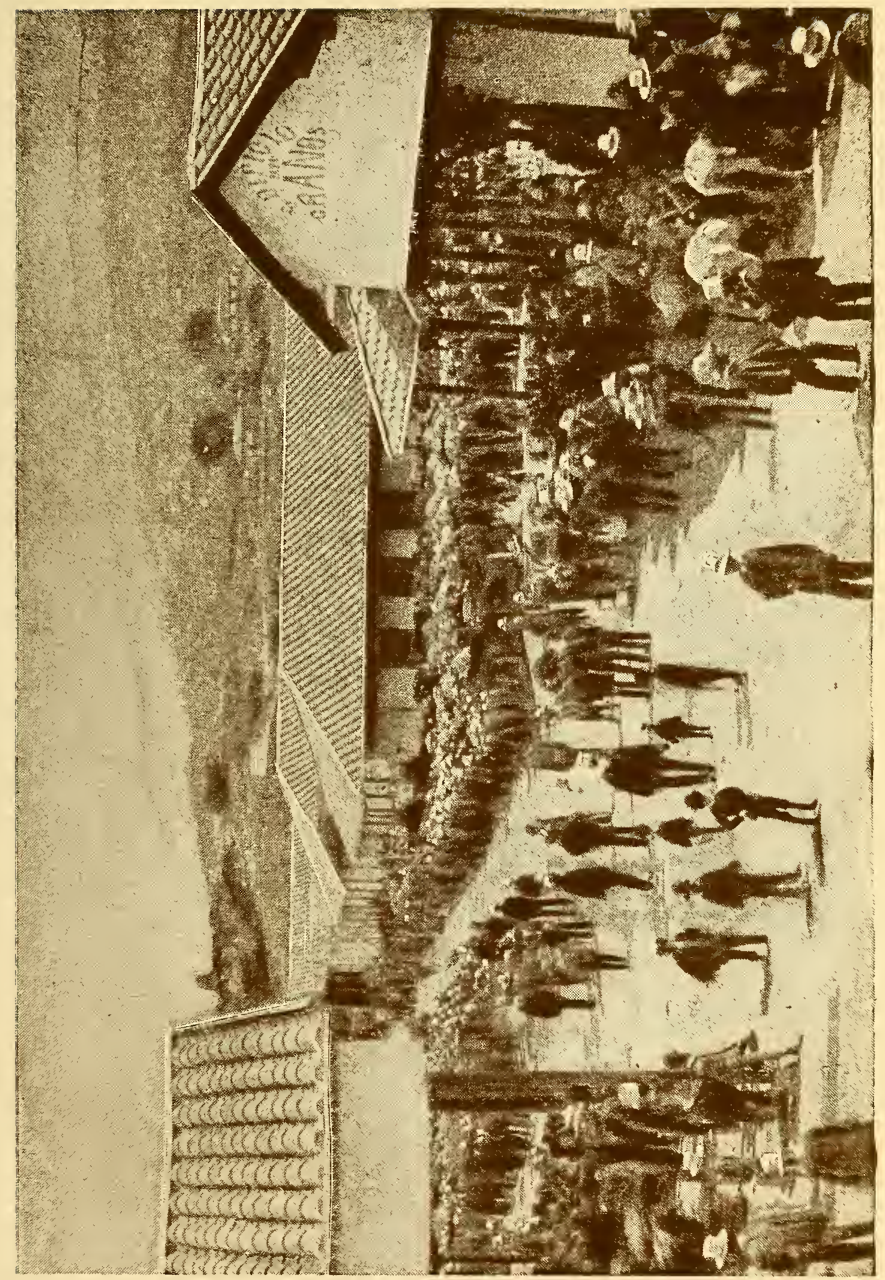





\section{ANDACROSS PANAMA}

presently found myself on a road which for mud, difficult passes, and utter abandonment was equal to anything I had ever seen. It led me through unhealthful regions, and I frequently noticed a nameless wayside grave, sometimes a group of them, mute testimony to the struggles which others had endured on this awful road. I kept pushing on, while touches of the fever came returning at times, and as I continued from day to day the thought was ever in my mind, would my end be a nameless wayside grave along that desolate road? By struggling on, I arrived at Zaragoza weak and tired, and there had another attack of fever, but knowing how to treat it, I was soon well again; and I can recommend to all travellers in the tropics to carry strong emetics, active purgative medicines, and quinine. If a fever is taken in time, there is little danger. Begin with an emetic, and let it be thorough, helping the action by abundant drafts of warm water, then take a purge, and a big one to act quickly, after that take large doses of quinine for a few days.

From Zaragoza I made canoe trips to various gold mines, and then went down the Nachí and Cauca Rivers, chancing it to find canoes for 


\section{AROUND THE CARIBBEAN}

the way. It was a rather doubtful experiment, but a merchant who was travelling with me said we would certainly find canoes going from place to place; and in this we were successful, though our necessities brought us strange travelling companions. Sometimes we went with a group of labourers who were seeking work, at others we travelled with merchants who peddled goods from their canoes, and sometimes we went along with cargoes of produce which had been gathered from the woodlands and jungles. We met with rough, irresponsible people who travelled as they fancied, were happy on any provision, and went their way drinking and gambling, cursing or murdering, as moved by the occasion. Alone I would have had a sorry time with them, but my companion was a merchant of influence, and affairs went favourably. One day a peddling merchant who was carrying us on the Cauca River stopped at a little settlement, and there began drinking. Soon he was intoxicated, and then presented us with his canoe, and ordered his men to take us on our way. We were glad of an excuse to go, and proposed to leave the canoe at the next stopping-place in charge of the owner's son, who was going on with us. 


\section{ANDACROSS PANAMA}

Without any delay, we pushed off from the shore, and, congratulating ourselves on our good fortune, went floating away down the muddy waters of the Cauca.

We had not gone far, however, when the man, now delirious with rum, started in pursuit, shouting for us to stop. This we tried to avoid, and endeavoured to keep ahead of him, thinking he would follow to the next stopping-place; but presently he plunged into the river, intent on swimming to the canoe in which we were travelling. We hurried to his assistance, and he clambered on board intent on vengeance. In drunken frenzy he seized a knife and made an attack upon my companion, but one of the boatmen, by a clever tipping of the canoe, sent him headlong into the water again. Then he grappled the side of the canoe, and we towed him to land, not without some difficulty, for he was determined to climb in again, which we all decidedly opposed. Fortunately, when we reached the shore, he was exhausted, and then we left him and his turbulent crew to quarrel, drink, and murder if they wished; while we, taking another canoe from a landing near by, went float- 


\section{AROUND THE CARIBBEAN}

ing away on the deep, muddy waters of the Rio Cauca.

In a day or two more we reached the Magdalena, and there found a stream which took us directly to Barranquilla. It was in the height of the dry season, and all the country for miles about the city looked dead and desolate, naked trees and withered grass, dust on everything, under a burning and indistinct sky. 


\section{CHAPTER XXIV.}

A CANOE VOYAGE IN THE OPEN SEA

I was not sorry to take the first opportunity to leave Barranquilla, though really it is a most desirable place, and shortly after my arrival I started for the eastern part of the country, beginning my journey with a canoe voyage across the swamps and lagoons to the eastward of Barranquilla. We were to have started at eight P. M. I was the guest of the owners, and came to the canoe promptly, but the men did not appear, and when at last they did come, it was well on toward morning, and then a most unpleasant journey was commenced. The swamps were full of mosquitoes, mud-banks, and stagnant water; but there was very little vegetation, only rank ferns, reeds, and mangrovetrees, and one wearied of the monotony; then the men were drunken and ugly; the owners of 251 


\section{AROUND THE CARIBBEA N}

the canoe had not told them they were to take a passenger, and my presence was not pleasing to them. First they demanded various sums of me, and then decided the best thing was to throw me overboard. We were now in a broad lagoon, and the prospect was not alluring, but fortunately my pistol was ready, and commanded some respect, though it is a difficult thing to control drunken men. A white man was in charge of the canoe, but he was as drunk as his men, and the affairs were becoming rather unpleasant. Presently the men began quarrelling among themselves; one struck another a heavy blow on the head with his paddle, splitting the scalp, and knocking him overboard. We all thought he was killed, but, on dragging him into the canoe, found he was not much injured, though for a time he was insensible. This incident had a quieting influence, and now there was not so much trouble, probably because about that time the supply of rum gave out, and we reached our destination in safety. I am told that after I left the party the quarrel broke out again with the first supply of rum, and that two of my late companions were killed. I make it a rule when travelling not to allow 


\section{ANDACROSS PANAMA}

any rum in the party, and usually make good progress, but I was only a guest while crossing the swamps, and so could not forbid the supply of liquor. I was now at a place called Le Siennega, and saw a great lagoon stretching westward as far as the eye could reach; about me an open sand-plain, where there were thornbushes, acacia, and cactus plants; and to the eastward the lofty ranges of the Sierra Nevada de Santa Marta, their sunburnt sides covered with trees naked in the dry season, and, to all appearances, withering away or quite dead. From here a railway took me to Santa Marta, a picturesque little place at the base of the mountains, where there is a good harbour, and desirable coffee lands among the hills and valleys back of the city. It was important that I should not remain here long, yet there were no means of continuing my journey, nor would there be for some weeks. This would never do, and I searched earnestly for an opportunity. Fortunately, some Indians were living near Santa Marta, making their livings by deep-sea fishing. They were used to the water, and I asked them if they could not take me out to sea and then along the coast in one of their big canoes. The leader 253 


\section{AROUND THE CARIBBEAN}

said, "Yes, but you know what will happen if the wind blows."

"Yes, I know."

"We are not afraid, if you are not."

I was not afraid, or, rather, there was a reason so urgent that I felt the risk was required, that I might prevent the loss of certain properties for the people I was representing; so I made a bargain with the Indians, and we would start that night when the moon came up.

There was no weakening on the part of the Indians. They said they would go, and they were ready on the minute, - a characteristic of these people which all must respect; but, unfortunately, this is little understood by white men, and hence there is endless contention where Indians are employed. If an Indian says he will, he can be relied on exactly to the last detail. A white man says he will, and the Indians expect him to be exact to the last moment in time, the last cent in money, and the last fraction of an ounce in goods; but an hour's delay, a mistake in accounts, and their confidence is lost; be a day late, and enemies will be found where friends were expected, but be exact to the minute, the pennyweight, and the letter, and 


\section{AND ACROSS PANAMA}

your men are your enthusiastic friends and faithful servants to the last extremity. Another mistake is to urge them too much to promise what they are doubtful of rendering. They will undertake it for you, but not under their word, and then results are doubtful. I sometimes think they would rather fail just to prove that they were right and you were wrong.

But to return to my journey. I was with the Indians, and they had said they would take me. Everything was ready at the moment. Without a word the Indians loaded the canoe, and we were presently making our way steadily toward the open sea. As the canoe was paddled rapidly across the still waters of the harbour, I felt secure in all that endurance and faithfulness could do to take me safely to my journey's end. In a few moments, we were out in the open sea; the mountains stood a bold, gloomy outline to the south, and to the north there was the broad expanse of the open sea, great waves and troubled waters furrowing its surface. All along the coast there were cliffs, and the mighty waves crashed against them repeatedly, and subsided; a moment of quiet, and then the repeated breaking of an255 


\section{AROUND THE CARIBBEA N}

other series of waves, - about us the night was damp and heavy. No one spoke; the naked Indians bent resolutely to their oars, and truly it required all their force to make headway. It was a fine night, only a gentle breeze was blowing, and presently we were making good progress; but as morning commenced to dawn the chief looked somewhat anxious; presently the wind would come; we must reach a bight among the cliffs, and he urged his men, but they knew as well as he, and bent with all their force. We were still some distance from our haven, and, as the light grew stronger, puffs of wind began to scud across the water, not very strong at first, but occasionally a puff would come with sudden, ominous force. The men worked as I had never seen men work before, untiring, forceful; and the great canoe went steadily on and on, but the wind was ever increasing. As the day grew in light, I could see that the naked legs of the Indians had been chafed through by the rough boards on which they sat, and that blood was dripping, but still they worked on, and made no sign of complaint. At times I thought the wind would surely drive us on the rocks; twice I offered to help row, 


\section{ANDACROSS PANAMA}

but the chief bade me sit still, and I have learned to do as the Indians direct; they will not tolerate interference; directions once given will be carried out in their own way to the end; so I watched the great waves beat against the cliffs, which one moment were covered with foam and spray, dashing upward many feet, and the next instant would be naked, and looking invitingly harmless, only to be covered again with beating waves and foam as the waters broke against them with crashing, ominous sounds.

We were fortunate to round a point of rocks successfully, the most dangerous place on our voyage, and just beyond found smoother water where better headway could be made, and presently we were camping for the day on a sandbeach in a bight among the rocks, the tired Indians throwing themselves on the ground to rest, but with no sign or word of complaint. The day passed pleasantly, and when evening came we went on again, and so for three days. The Indians worked faithfully, and brought me in good time to my destination; then, according to their custom, they turned back again with scarcely a word. They had done as they agreed, and simply went their way.

257 


\section{AROUND THE CARIB BEA N}

\section{CHAPTER XXV.}

THE SIERRA NEVADA DE SANTA MARTA MOUNTAINS

The Indians had brought me to a little town called Dibulla, where I completed titles to a great quantity of mineral lands for the company I represented, and then began a series of explorations.

First I examined the base of the mountains, and one day, accompanied by a number of men, I was working on a rolling savannah where the ground had a rather favourable appearance for coal. As we went about among the hills, we jumped a deer from a clump of bushes and tall grass. It ran in great fright for a long distance, and then stood still where we could just see it, much too far away for a shot. I tried, however, pointing my rifle about ten feet up the wind, and shooting high over my sights; we 


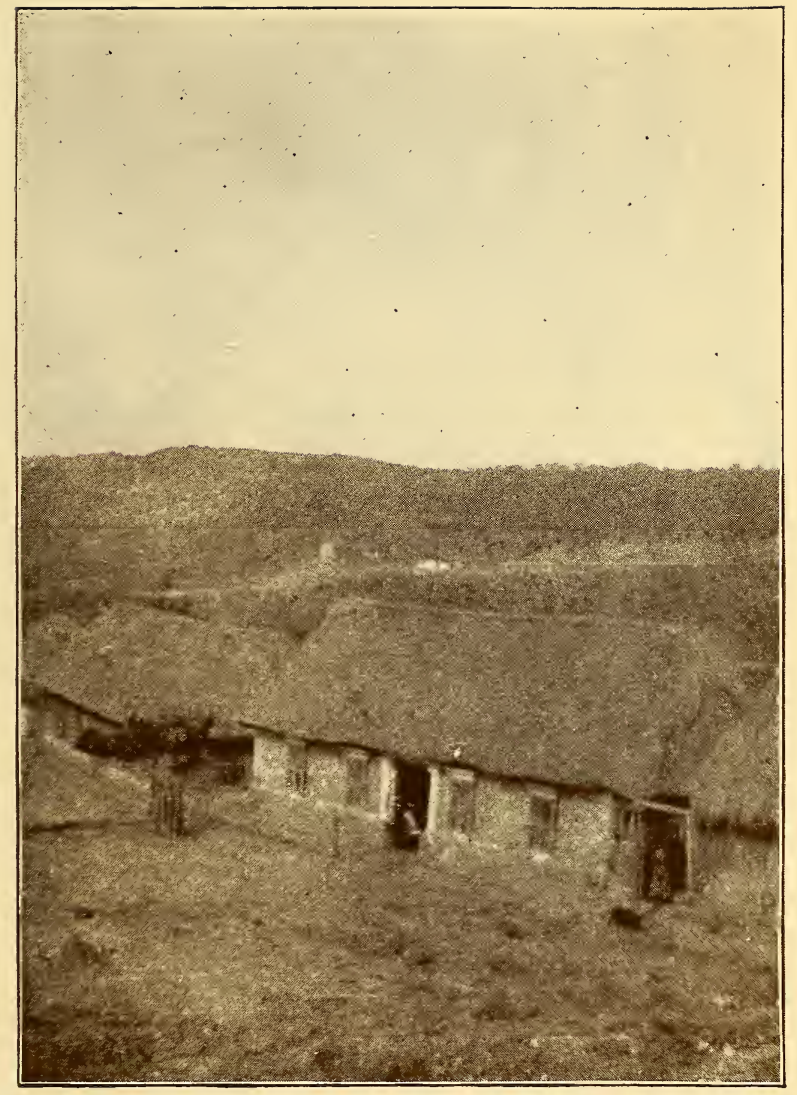





\section{A NDACROSS PANAMA}

stood an instant watching; the deer put down its head to feed, then jumped suddenly, and we could see as the ball struck the bank beyond, and that it had just grazed the animal's neck. If it hadn't put its head down to feed, I would have killed it.

Some of the men said it was hit hard, and started in pursuit, but they were evidently mistaken and soon came back. Then, as we were returning to the hut, the men were talking it over, wondering, and still exclaiming at such a remarkable rifle and such a wonderful shot.

We had no meat in the camp, but next morning, as I was about starting for the woods, one of the men ran and brought my rifle, saying as he came, "Never mind; this will bring us meat, and plenty of it, before night."

It was a beautiful day, and presently we started a flock of wild turkeys, and I had the pleasure of missing in succession three unusually fine shots at birds sitting perfectly still in the open branches; but with such a reputation as I established, it was all blamed on the rifle, or the day, and even the light might have been deceptive. We went on, and soon fell in with another flock of turkeys, and I missed four 259 
shots, which was certainly discouraging; but when, about three o'clock in the afternoon, I had missed twenty-seven good shots at turkeys, my companion said, with many apologies, that the rifle must have gone wrong in the night, and, as it would be convenient to have some meat, perhaps he had better kill the next turkey with his shotgun; which he did in a very short time, securing three without much difficulty. I thought of the men at camp, and remembered what they had said, "Never mind; this will bring us meat, and plenty of it." I looked at my rifle; felt like kicking it all the way to the ocean, and then jumping in after it.

I didn't eat turkey that night; I preferred fish; and it wasn't very good fish, either; the fact is, it was rotten fish, but it was better than turkey.

I tested that rifle a few days later, and found the sights were in good order, and I regret to say that from that day to this I have not done much shooting.

A time passed examining lands and mineral outcroppings at the base of the mountains made me eager for a change, and a few days later, my preparations having been finished, I was 


\section{ANDACROSS PANAMA}

anxiously waiting for an opportunity to carry my explorations to the lofty, almost unknown, regions among the mountains rising just before me.

I was anxious to start at once, but in Spanish America the great day is to-morrow, and why should one hurry when a better day is always coming? Yet this disposition is most annoying to travellers, who cannot understand the indolent disposition of the natives; while, for their part, the natives are firmly convinced that all foreigners are crazy.

It seemed almost unreasonable that better progress could not be made, but it was important to have animals brought from the mountains, because none others could climb the rough trails. I was put off from day to day, and constantly annoyed by new causes for delay. At last I was informed that the animals had arrived, or rather, some were passing that way which I could engage if I wished. I ordered them at once, and my surprise may be imagined when three shaggy-coated bulls were driven up to my door. I was disappointed, but of course did not want them; I was looking for animals accustomed to mountain trails.

261 
"These are the proper animals," their owner said; "only bulls and oxen can go up there; two are for your baggage, and one is for you to ride."

I immediately changed my plans. I wasn't riding bulls; perhaps I was prejudiced, but I preferred to walk. I engaged the strongestlooking animal for a light cargo, and wanted to start at once; but no, it was late, and the next day would be Good Friday, a bad day for travelling, and the men were not willing to go. By angry persuadings, I at last forced from them a reluctant consent to start the next morning, though they assured me we would have trouble, that it was a bad day, and evil would surely follow us.

Next morning everything was ready, but the owner had decided that his bull could not go out on Good Friday, not because of any respect for the day, but for fear that some evil might come to the animal.

Fortunately other bulls had come down from the mountains, and we secured one that looked like a fine, big fellow, and started on our way. But evidently this bull had ideas of its own about travelling on Good Friday, and we had 
not gone far when he began to rear and plunge, jumping about with such violence that the cargo was scattered all over on the ground, and the pack-saddle broken and trampled to pieces; then the bull took to the woods and disappeared.

"There," said my bull-driver, "I told you we could not start to-day; now see what has happened; we must pack up all the things and go back to the house."

"Nothing of the kind," I said; " go back and bring another bull."

He looked at me in astonishment. "After such a warning, the fault is yours; if you make us go, the trouble will come to you, not to us. The Devil is in the woods to-day."

A sharp command, and he hurried away, followed by my servant, who was equally astonished at my temerity. After a time, they came back with a tough-looking little bull, the pack was rearranged, and we started on again. I felt a little sinful myself, but with all the feastdays and rest-days to follow, it seemed best that I should push on at once.

After we were under way, travelling was about as usual, and the fears of the men were overcome to some extent. Our route took us 263 


\section{AROUND THE CARIBBEAN}

down the beach for about six hours, and then along a trail over low ground toward the mountains. Here, in spite of the day, we were fortunate to get across some wet places without difficulty, though the men predicted every trouble, and perhaps the loss of the bull and cargo, because, in spite of my infidelity, the Devil would surely catch the bull by the legs and drag him down into the mud; and, if not this, a snake would come and bite me. Yes, I might laugh, the Devil was bigger than I thought; wait, and I would see. But I didn't see, and, as stated, we passed the mud-holes in safety. A little further on, we met a party of men also travelling, and there was a moment of mutual surprise between them and my men; then explanations followed, and it appeared that both parties were travelling from necessity.

One of the men carried a gun, and when my men asked him if he had shot anything, he replied: "Don't you remember what day it is? What's the use of firing? It would be impossible to kill anything."

" True," replied my man, "I had forgotten."

Then we went on again, and a little later got a shot at some turkeys. I took careful aim, 


\section{A N D A ROSS PANAMA}

and missed, of course, and I know why: it was the Devil, and he is in my rifle yet. A little later we came to a hut at the base of the mountains, and there camped for the night, and nothing happened. But in the morning we missed the bull, and the men said, "We told you so; you will never get up the mountain. You started Good Friday. The Devil is with you," and other encouraging remarks.

I gave them my opinion in words that were forcible, if not strictly moral, and ordered them to find that bull; which they did in a short while, where it might have been expected, quietly feeding on some long grass near a spring run. Starting on again, we presently began to climb the mountains. Our way led us to some of the most beautiful places in all South America, an ascent up through a tangled jungle, with vistas of the blue ocean in the distance, and occasional glimpses of the lofty mountains beyond us.

At one place in the road, the men took me stealthily to a high bank, overhanging a pool of clear water, where I had an opportunity to see one of the largest alligators, perhaps, in all the world. I have seen others almost as 265 


\section{AROUND THE CARIBBEAN}

large, but none that appeared so big and heavy. I fired at him, but the men said it was a waste of ammunition; bullets could make no impression, that is, not from above, and one could rarely approach him from the river, he was so wary; and when one did succeed in getting near enough for a shot, he would always show fight, and was considered too dangerous for an encounter.

On our first day's march there was little of interest, only continued fatigue. We had expected to stop for the night at one of the camps prepared by the Aurohuaco Indians for the convenience of their people, who frequently use the road on which we were travelling. We found these camps too dirty for use, and full of vermin, and were forced to keep on, hoping to reach a house before night.

We were making good progress, but along in the afternoon the bull lay down, as if exhausted. "We told you so," came from the men with sundry variations. I did not stop to listen to their remarks about the powers of Satan, but fell to work vigorously urging the bull on, and presently succeeded.

About sunset we had crossed the first range 


\section{AND ACROSS PANAMA}

of mountains, and were passing through a mountain valley, where the gathering shades of the evening made pleasant travelling, and the bull plodded along patiently, as if it understood the situation. As it began to grow dark, we were approaching a higher ridge of the mountain, and I felt many misgivings as to our ability to reach a house, which the men now assured me could not be far away; but just then we saw a light, and in a few minutes we were standing before the door of a well-built hut, where a solitary Indian, named Mario Henio, was living with his only child, a pretty little girl of some twelve or fourteen years. The Indian came to welcome us, holding three pieces of sugar-cane in his hands, one for each, and it was pleasant to receive his grave, kindly greetings.

I was pleased to see that my guide's first thought was for the bull, and the tired animal was made comfortable with an abundance of fresh grass. It had done good work that day, and a pack-mule could never have come so far.

From our provisions a bountiful supper was prepared, which we shared with the Indian and his little girl; and then we all went to bed, 


\section{AROUND THE CARIBBEAN}

where I found it comfortable to have my blankets gathered close around me in my hammock, while a fire in the centre of the house gave a softness to the crisp mountain air, but did not quite warm it. I had a beautiful sleep that night, and when I awoke in the morning my men were preparing the cargo, and the pretty little girl was busy getting breakfast. We had Indian provisions, and a quantity of rice and dried peche peche, a little bivalve, Donax denticulatus, which is found in great abundance at times in the sand along the sea at Dibulla. The flavour is delicate, and I had become very fond of them, and on starting for the mountains had taken a good supply among our provisions.

After breakfast I gave some silver coins to the little Indian girl, whose delight and happy enthusiasm ov $r$ the gift was a pleasant opening for the day. We had not far to go, and the only incident was the necessity of fording a mountain stream, where the water, originating in the perpetual snow of the higher mountains, was so cold that it made the flesh creep.

About noon we reached Pueblo Viejo, where additional guides and a fresh animal were to be engaged. While preparations were being made, 


\section{AND ACROSS PANAMA}

I had an opportunity to look about me. The place was delightful, a narrow valley among high mountain peaks, where in the distance the great snow-clad summits of the inner range could be distinctly seen. Opposite the little village was a solitary conical mountain, isolated, and not so high as the others, more regular in appearance, and covered with green grass to the very top. I determined I would explore it, and later told my men we would stop for a day or two at Pueblo Viejo.

As sunset was approaching, I went part way up that peculiar mountain to enjoy the view. I must have gone higher than I thought. After a time $I$ found a seat on a bare spot, and alone in almost unknown mountains gave myself up to the enjoyment of the scene, a wilderness of rugged peaks towering all about me, the light of the sunset falling on them in sharp contrast to the gloomy shadows lengthening in the valley below. It was fascinating. Presently shadows began to gather over the mountains, and then, as the darkness of the tropical evening came, following after the sunset, the great peaks appeared to rise up higher and to draw nearer, as if to crush me, a tiny creature intruding 269 
himself before their majesty. Fascinated, I watched for a time, and then suddenly realized that night had come, and I was alone in the mountains. At first I was frightened, but on second thought I remembered that the trail went all around the base of the mountain, and that, go down as I would, I could not miss it. There was a little danger from poisonous snakes, but that was all, and I began at once making my way down wherever it seemed easiest.

The grass had been burnt over, and to avoid snakes, I followed the burnt places, and made fair progress; but I had to go carefully, as the mountain was steep, and a careless step on the coarse, angular gravel might give a bad fall. After going some distance, I saw ahead of me a black line extending some distance down the mountain, apparently a path leading exactly where I wanted to go. I considered myself fortunate, and, hurrying toward it, put my foot down carefully, so as to get a firm hold on any loose ground, and the next thing I knew, I plunged head first into darkness, and fell on my back and shoulders, and then began slipping down, to where I did not know. Fortunately no bones were broken, but visions of 


\section{A NDACROSS PANAMA}

snakes and stinging things nearly frightened away what little breath was left in my body.

With the energy almost of despair, I clutched at the ground, and dug my feet into the loose gravel to hold myself from slipping on further; then I found I was in a narrow chasm where I could hold on to either side and keep myself in position, while a company of bats flew tauntingly about in the dark.

I saw now a line of light above me, and immediately began climbing toward it, a hand and a foot on each side. As I went higher, the chasm became wider, and I was just able to reach the top, and there, with a hand on either side and black darkness opening below, hung as if exercising on the parallel bars, and it seemed only a question of a few minutes when my strength would give out, and down I would go again, into what I did not know. To practise gymnastics with the unknown opening below one is hardly to be recommended. I had a hand on either side of the chasm, but there seemed no way to get both hands on one side. I kicked and struggled, and was just about to drop exhausted, when, sinking gradually, as my strength weakened, one foot struck against a 271 


\section{AROUND THE CARIB BEA N}

rock or stone on one side of the chasm. It gave an insecure support, but, bracing my foot against it, I made a sort of spring, grabbed the long grass at one side, and hauled myself out, fortunately more frightened than hurt.

I looked about me, a dizzy feeling in my head, and then saw some lights down the mountain, and heard excited voices calling my name. I answered, and then a voice came back through the darkness telling me not to move till guides arrived to show me the way down. Presently three frightened men came hurrying up, and asked at once if $I$ had fallen into a pit, and when I said yes, they told me that some of those openings were hundreds of feet deep, and no man in the settlement would dare to cross that mountain at night without a good torch.

We did not say anything more, but went directly down the mountain and back to the house, where I had something to eat, and then went to my hammock, thoroughly exhausted.

Next morning I was awakened early by one of the men, who called into my room, "Get up quickly if you want to see the mountains; they are all as if reflected in a mirror." I hurried out, and truly it was a beautiful sight: the air 272 


\section{AND ACROSS PANAMA}

was so clear that every mountain, yes, every rock and every leaf, stood out in bold precision. The sun was not yet up, at least it was not shining in the valley, but there was light everywhere, clear, cool, and brilliant, yet no signs of the sun. I did not lose a moment, but hurrying on my clothes, started to climb the green mountain. On the way up, I saw the hole in which I had fallen. It was about twenty feet deep, and how I escaped without serious injury I cannot tell. The hat I had worn was lying at the bottom of the chasm, but I had no time for that now, and hurried on, wishing to reach a high elevation before the sun rose. As I went up, some of the higher peaks began to glow in the sunlight, and then long, golden rays came streaming across the valley, still well above my head. I hurried on, but presently the sunbeams increased, and it was time to stop and watch. I stood on a spur of the mountain in a deep shadow, at a point above some, and below others, of the mountain peaks; all up and down the valley there were dark places in sharp contrast with great pathways of light ever increasing as the sun rose higher. As I watched, there came a flight of swallows, hundreds and hun273 
dreds, sailing swiftly down over the valley, passing through sunlight and shadow, some above and some below me; and the morning was so clear that I could see each one of them with a distinctness that scarce seemed real, and, as they sailed swiftly on, their soft, rippling cries filled all the air. Then, while I was watching, the green peak behind me glowed with a sudden light. An instant more, and the shadows about me seemed to sink down, and then, in a burst of clear light, the sun rose over the mountains; and Easter morning had dawned. I waited a few minutes more, while the last of the swallows went sailing on down to the lowlands, and then I went up to the top of the green mountain. It was a beautiful view from there, but that strange, clear light had gone out among the mountains, and the air lacked something; the scene was tame in comparison. After looking at some deep openings in the mountain, where, if one had fallen in, there would have been but little chance of ever getting out, I started for the house. On the way I cut a stout stick from a clump of bushes, and after a rough descent arrived at the house without accident, just in 


\section{A NDACROSS PANAMA}

time for breakfast, which, it is needless to say, I enjoyed thoroughly.

Arrangements to continue our journey were completed that afternoon. Everything was most satisfactory, and I was to start the next morning. I asked the men what had become of the Devil now, but their faith was not shaken, and with anxious faces they warned me to be careful, or he would have me yet. I joked with them for a time, and found considerable amusement in their unreasoning fears and absurd answers.

I went to bed feeling well satisfied, but not for long, because my hands began to itch and pain suddenly, and I could not understand what it was. Presently it became so annoying that I got up, called one of the men, and asked what it could mean. They didn't know, but presently one asked to see the stick I had cut in the mountains. It was standing in the corner, and I brought it to him. One look was sufficient, and he ordered it thrown out of the house. "Pringa Mosa," he said; "didn't you know better than to cut that?" Then he told me that it would not be very bad, as it was not the worst kind, but that there was no help for me. 275 


\section{AROUND THE CARIB BEAN}

One of my men had the impudence to make some remarks about the Devil and Good Friday, and the first thing I could lay hands on went flying at his head, but he was good at dodging and no harm was done.

Next morning my face and hands were painful and badly swollen, but everything was ready for an early start, and I decided to push on. We crossed a high mountain called El Barco, and made our way down to the beautiful valley of the Rio Ancho, where the grass was long and abundant, and all the air soft and cool like a bright day in October. Here we found a group of houses of the Aurohuaco and stopped for luncheon.

The houses were empty, and the silence of desertion, intensified by the rocky heights overlooking us, brooded undisturbed; only our voices jarred against it. The breeze rustled the leaves on the trees, and the birds hid themselves in the bushes as if fleeing from some unknown danger. There was a mystery about it all. My guide shook his head, and told me that he was afraid the Indians had run away and it might be dangerous for us to stay in their country.

"Why so?" I asked. 


\section{A N A CROSS PANAMA}

"Because this means you are not welcome, and it may be that as we go on they will roll great stones down on us from the mountains above the path. You can't depend on them; they are a strange lot."

We ate our luncheon among the deserted houses, and then started on again, anxious to reach the Aurohuaco capital, San Miguel, before dark. The road took us on up the valley, now descending to a rushing river, again climbing over a projecting spur from the mountain, and after a time we came to a curious suspension bridge, made by the Indians, who had laid two long poles across a chasm, and then tied branches with convenient joints to them, in order to hold in place a series of logs lying on the angle formed by firmly binding together the lower ends of the branches.

It made a fair bridge, but rather difficult to walk on, as it swayed uncomfortably, and no attempt had been made to shape the narrow logs which formed the foot-path. I got over safely, though several times my boots, which were very slippery, threatened to give me a bad fall.

Across the bridge, I found myself on a sort of table-land within the valley, where there were 277 


\section{AROUND THE CARIBBEA N}

boulders and'blocks of granite lying about. The trail led to another flat place, and then up a terrace to a broad part of the valley, where presently we came to a gate, and then beyond us saw the city of San Miguel, a collection of one hundred to one hundred and fifty little round houses, protected by a strong fence, and standing on an elevation at the foot of a great, bald mountain. Just outside of the city we came to the Cansa Maria, where the Indians hold their religious ceremonies and dances.

It was a round building, somewhat larger than the houses, with a high, conical roof, and three poles at the top like an inverted tripod. On each of these poles was a clay cylinder, resembling a great earthen jar without a bottom. These were slipped over the poles and rested on the roof; apparently they were intended to hold the thatch in place, and were perhaps to serve as a sort of ornament as well. The building was circular, the sides of open triangular latticework, but inside we found nothing, and in a little round house behind the Cansa Maria there was nothing. The guide muttered to himself, shook his head angrily, and we hurried on. Soon we were among the houses, but a city of 


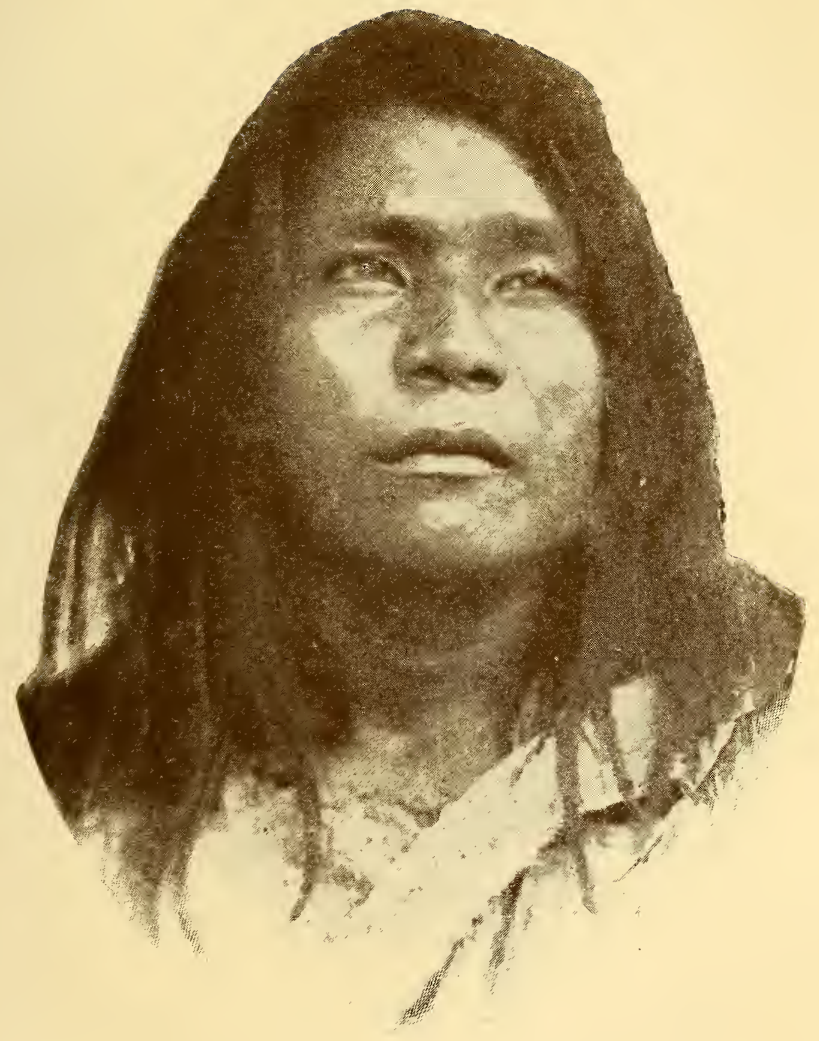





\section{A N D ACROSS PANAMA}

the dead could not be more desolate; there was nothing: household utensils, animals, people, all were gone. Even the little Catholic mission was deserted. We had been expecting to secure fresh provisions from the Indians, but had to content ourselves with the things we had brought. I didn't care, because there was plenty of peche peche, but my guide complained loudly, saying he expected bread, crackers, cheese, canned meat, and other delicacies usually carried by travellers; things which I had left behind long ago, as being a nuisance to carry, and such an expense for freight, etc., that it was cheaper on a long trip to buy eggs at a dollar each, when pressed for food, than to carry provision in bulk.

Presently we heard a rooster crow on the other side of the river. It had evidently been forgotten, and the guide went after it. $\mathrm{He}$ returned shortly, and we had chicken stew, rice, and an abundant supply of peche peche, which I considered much better than the chicken. We had plenty of strong coffee, and I was as well contented as one could be who had expected to meet a strange, almost unknown, race of Indians, but had found only a deserted city. 
We slept that night in one of the empty houses, and next morning the guide, who had become very unpleasant, said it was not safe for us to go on, and that we must return at once. One of my men gave a satisfied laugh, and I thought I heard him say something about the Devil and Good Friday; but he suddenly went about his work with great energy, and so nothing came of it. For my part, I was not going back, and after a few strong words, my guide agreed to go on to Macatama, where there was a Cansa Maria, and it might be that the Indians were there for some ceremony or other; but he reminded me that, if an avalanche of stones and rocks came rolling down, it would not be his fault; the Indians would not harm him or the others, but they would catch me if they could. I told him that I believed he was lying, and requested him to keep his mouth shut, and added that, if he was afraid to go on, I would do so alone. He muttered angrily as he arranged the cargo on his bull, and after a poor breakfast we started on.

The valley now became narrower, and the trail led along the sides of the mountain. At times the guide said that he could see Indians 


\section{AND ACROSS PANAMA}

high above us, keeping watch, but they were so far up that I could not make them out.

After a time we came to a few houses and a Cansa Maria at a place called Takena. These were also deserted, and after stopping for luncheon, I ordered the guide to move on. A fog was coming up, and he complained angrily, saying that it was dangerous; that it might shut out the path; that the Indians would take advantage of it, or the bull would slip and be killed. I simply ordered him on, and he went, declaring that he would hold me responsible if anything happened to the bull.

The road was quite easy, and we made good progress. Presently great banks of thick fog gathered around us, and then the trail suddenly became a narrower track, leading diagonally up the steep side of a great grassy ridge. Around us the silence was intense, broken only by the scraping of our feet on the loose gravel along the trail, or the cry of some frightened bird that flew up suddenly and then disappeared in the fog. From far below us came the indistinct sound of rushing waters. We could not see ten feet on any side, and as we went on it 


\section{AROUND THE CARIB BEA N}

seemed like climbing up to some enchanted place on a pathway leading over the clouds.

After two or three hours of cautious climbing, the conical roof of a house suddenly loomed up out of the fog. The guide stopped, saying, "This is Macatama; we can go no further tonight; the next house is a long distance off."

There was nothing but to do as he said, so, making ourselves comfortable in the deserted Cansa Maria, we prepared for the night, the guide saying that this was the utmost that could be expected; that there was nothing to eat, and next morning we must hurry back, and get out of the Indian country. I did not say anything, but was fully determined that when morning came we would go at least one day's journey higher up among the mountains.

The next day was as perfect as could have been asked, and all the air was fresh and crisp. We had coffee, and then I said we were going on higher up among the mountains, and we did, the guide driving his bull on in a furious rage, muttering all sorts of curses under his breath. After about an hour's hard walking, we came to three or four little houses at the head of the valley. Here the guide stopped, drove the bull 


\section{A NDACROSS PANAMA}

into the enclosure around the nearest house, and said, "This is the end. Above us there are no more houses; the trail stops here; the bull can go no further; the Indians have run away; there is no one to carry your things; if you were the Devil himself, you could not reach the top of the ridge alone. Order breakfast, and we will go back."

I considered a moment, then I told one of the men to stay and cook breakfast, and that I would go with our mountain guide and my servant a little farther up, and at least see the base of the main range. Then $I$ took a cake of brown sugar in my pocket, left a frightened man behind me, and with the two others started on, saying we would be back before breakfast was ready.

We had gone some distance when my guide pointed out a round peak below the main ridge, saying that we could go up there, and that he had taken scientists, particularly botanists, that far, and, if I wished, we could go over there and climb it, though it would be hard work.

I didn't want this, and had other plans; so saying that I wanted to see the rocks, we kept on, going gradually higher along the basse of 283 


\section{AROUND THE CARIBBEAN}

the main range. To my intense disappointment, a fog began to gather, and it seemed useless to go further. Just ahead of us there was a great pyramid of granite, a mountain in itself, standing up against the main range. I thought if I could only have reached that point before the fog came, I would have been satisfied.

I turned reluctantly back, pausing for a moment to watch the fog-banks, as the wind swept them in eddying curves up the peak of granite just above me. Then I noticed that, as these fog-banks came against the rocky mass and were carried whirling upward by the wind, they faded away before reaching the top; and I turned back up the mountain again, feeling sure that the day was clearing, and telling the guide that I wished to see that mass of rock. He said we would be lost in the fog; that it was dangerous; we were on the paramo now, and he would not be responsible. I made no answer, but pushed on, and by the time $I$ reached the precipice at the foot of the granite peak, the fog was rapidly disappearing as if for my special benefit, though it hung about the lower peaks all day, and I did not have a very extended view. On reaching the precipice, I found that I could 284 


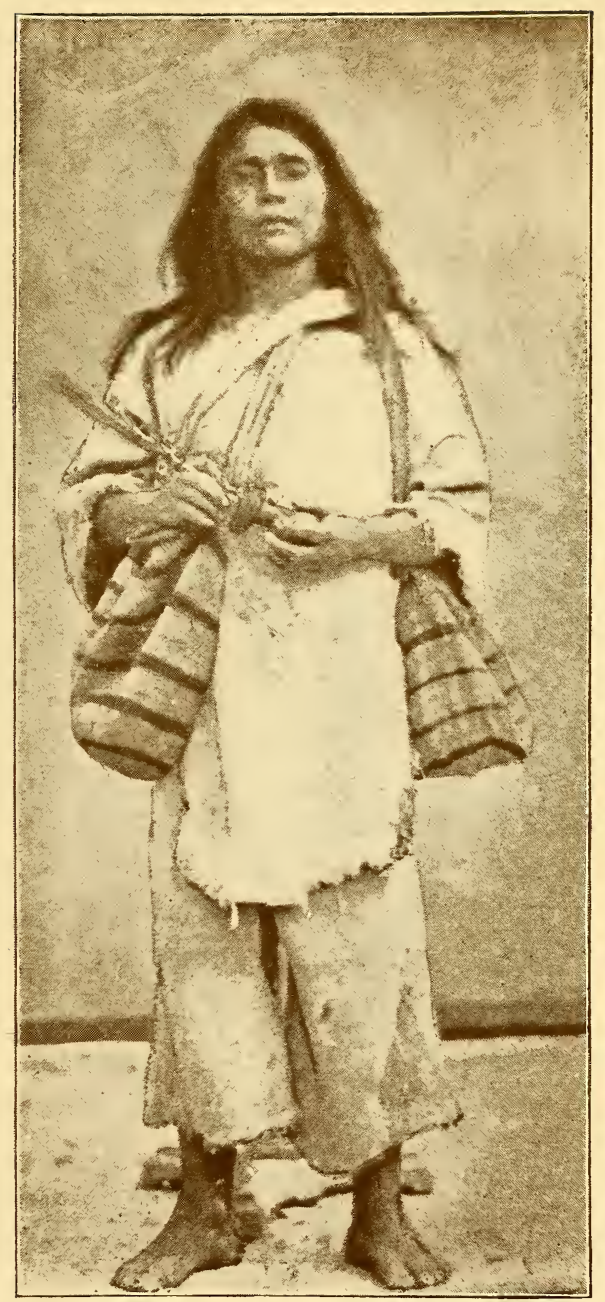





\section{ANDACROSS PANAMA}

make my way along its base over masses of fallen rock, and that this would lead me along the western side of the peak and directly up toward the main range.

It was hard climbing in the rarefied air; the guide grumbled violently, and presently my servant gave out. He had the strength of an ox, but his weight was against him. I had no time to wait, and, after about an hour more, stood on the side of the main range with the granite peaks just below me.

There was a ledge of rock and precipice further to the west, and, thinking that I could climb along its base to still higher elevations, I started as well as I could, making my way toward it over the broken masses of rock.

My guide gave a cry of rage, hurried past me, and sat down as if to bar the path, saying, decidedly, "Señor, we go no higher."

I protested angrily, and ordered him on.

"Not I," he replied; "we are on the upper paramo, all bare rocks and unknown country; no one has been here, not Spaniard, American, or Indian; I go no further."

I ordered him on again.

"I will not go," he said; "you are not rea285 
sonable. I have taken scientific men in the mountains a great many times. They don't ask to come to these places; they go where it is known, and where they can carry their provisions; then they spend a few days, collect their plants, butterflies, rocks, whatever they want, and go back contented, but you, you go on as if you thought yourself the equal of the Devil; he might go up there, a man could not."

I told him to hold his tongue. "But suppose the fog comes," he protested, "how will we get down? To spend the night here on the paramo would be death ; be reasonable and come away."

I hesitated at this, he seemed so much in earnest; perhaps I was not reasonable. Then I looked up at the dark ridge of massive rock and the snow peaks glistening in the sun. What if I could never come again? That was enough. I told him to sit where he was, so that I could call to him when I came down, and then I hurried on. It was slow work at first, but after a time I got over the broken rocks, and made my way along the base of the second precipice, getting higher up at every step, and presently I came to a broken place in the rocks, where I managed to climb up to the overhanging ledge, and there 


\section{A NDACROSS PANAMA}

found very easy walking to a smaller precipice. To reach this and climb over was not difficult, and then I saw before me a sloping terrace standing along the main range, with the rocks and snow-covered elevations of the backbone of all the mountains rising directly above it. There was a little soil caught here, and an abundance of coarse grass growing among the shattered pieces of granite that were lying all about. A group of wild cattle quietly feeding on the terrace seemed surprised, but not alarmed, at my coming among them.

It was an easy thing now to hurry across this sloping terrace to the rocky ridge and clamber up at a convenient point, and then sit down in a place exposed to the sun, where the rocks were slightly warmed and comfortable. Around me there were ridges of solid rock and snow, irregular peaks, some above and some below me. Where I sat, one leg almost hung over a black abyss, made where the ridges came together. It looked dark and threatening, and one could only shrink away in dread of it. I could hear the sound of waters which I could not see rushing along in its depths, and great stones kicked over with my foot, as I sat there, disappeared 287 
and fell so far that I could not hear any sound of their striking on the bottom; across this deep place there was a blue glacier, and a little further on the white peak of the Ahorqueta rose over a thousand feet above me, glistening in the tropical sun. A mantle of fog hung about the lower mountains, and I could see nothing of the lowlands, but, shut in apart from all the world, was alone among those mighty mountains; and I was so very little, the silence was so deep and unchanging, that I scarcely dared to move, sitting in awe as of some great presence that might have been disturbed at my intrusion. I sat there a long time, when I became used to my surroundings, and began climbing about among the rocks ; but it was difficult work, and in that rarefied air it was an effort even to raise my hand to my head. After a time I noticed that the surface of the fog was swelling up, and falling away again, in great, white billows. It was a fascinating sight, but I could easily see that it was creeping steadily closer, and knew that it was time to return to my guide.

I started at once, hurrying on down the mountain, and presently began calling, but there was no answer. I hurried on, still calling, but only 


\section{A N D ACROSS PANAMA}

the echo of my voice came mocking back, repeated from crag to crag and across the open spaces among the mountains. Could it be possible that I had lost my way? I called again and again, but there was no answer.

Then I stopped calling, and after considering a moment began retracing my steps till I could find some point that I was sure I had seen coming up; but now everything was changed and confused. It was not that I had lost the general direction, - the streams and mountain ridges indicated that, - but the question was to find the path down among those rough, bare rocks.

I noticed now that the fog was growing alarmingly. A night in the snow on the upper paramo is dangerous; I knew that well, and I had nothing but sugar to eat. I saw that I would have to make a dash for it in an effort to reach lower elevations before the fog closed in around me. I hurried on, taking advantage of any opening among the rocks, and presently saw far below me the granite peak that had attracted my attention coming up. It looked nothing but a great pointed boulder now, resting on the side of the mountain, but this was a landmark, and I seemed to make better prog289 


\section{AROUND THE CARIBBEAN}

ress. After a time I called again to my guide, but, as before, the mocking echoes were my only answer.

I went on, becoming more alarmed every minute as the fog rolled steadily in on me; but I was drawing closer to the granite peak, and a little further on was delighted to meet my servant, who was making poor progress, and frequently stopping for rest. I asked anxiously for the guide, fearing that he might have gone up the mountains and become lost trying to look after me; but my anxiety was turned to indignation when my servant told me that the guide had rested a long time, and then started indifferently down the mountain. He had told my servant that I would certainly be killed, and that he for one was going back to have something to eat, and that, as I would go up the mountain, I could come down alone, or die up there.

On hearing this, my servant had come up to look for me; he was making poor work of it, but I was glad enough to have him. We hurried on down the mountain, and presently caught sight of the guide far below me, and a little beyond him could see the trail winding down the 


\section{A N A A ROS PANAMA}

range. He was taking it leisurely enough, and stopping now and then to pick herbs, which he sold for medicine in the lower valleys, and I could see that he had quite a bundle of them.

I called, but he was too far below to hear me; then I sent a big stone crashing down the mountain. He heard this, though it did not come anywhere near him, and he stopped, looking up in alarm. He saw us, and I pointed my rifle at him, and then he stopped in good earnest. We hurried on, and just as the fog closed in around us, we reached him; if we had delayed only a few minutes longer, results might have been serious.

There was nothing to say; I simply ordered him to take us to camp, and keep his mouth shut. Whenever he spoke, I simply repeated this order, and presently he became decidedly alarmed. The fog gathered thicker and thicker, and by the time we reached camp it was growing very dark. There we found the man I had left to cook frightened almost out of his wits, feeling sure that we had all been killed, and satisfied that the Indians would soon come and murder him.

He had a lot of rice, peche peche, and veg291 


\section{AROUND THE CARIBBEAN}

etables cooked together, and, as brown sugar is light diet for a day's work, we all ate heartily.

Then we went to bed. I had a frightful headache, and for a time was afraid that $I$ would be seriously sick, but after awhile I fell asleep, and in the morning was better; and what a morning that was, the air so perfect, the sky so clear and blue, and the mountains standing in bold outline, free from all fog or clouds. It seemed a shame to leave such a place; we had plenty of brown sugar and some rice left, and I hesitated about going down the mountains. While I was considering, I heard my guide saying, "Now we know he is crazy," and my servant gravely proposed to strap me on the bull with the cargo, and so take me down out of danger. Of course they would never have dared to do it; but when my servant earnestly advised me to give it up, and told me that to stay on the paramo without proper food was a real danger, pneumonia and fevers frequently resulting, I decided to start for the settlements; because it was only reasonable, and the advice of a man who had taken the risk of coming to my assistance when he thought $I$ was in danger was worth considering. 


\section{A NDACROSS PANAMA}

Returning to Pueblo Viejo was not difficult, and after resting a short time $I$ explored various places among the lower mountains, but without particular incident. 


\section{AROUND THE CARIBBEAN}

\section{CHAPTER XXVI.}

\section{AMONG THE GOAJIRA INDIANS}

HAving seen the mountains, I now started along the coast, in a canoe once more, but this time it was quite safe. There were no rocks, and the wind blew mostly off the shore, so that we were protected by the land; and at places the sea was so smooth that the men hitched a long rope to the canoe, and walked along the shore, towing it after them, much in the manner of a canal-boat. For two days we made our way along the coast, and then came to the city of Rio Hacha, an hospitable place, a typical trading town; where Indians came and went, bringing produce, and the merchants were doing a thriving business, trading and bartering.

I found kind friends in the city of Rio Hacha, but the place itself was uninteresting. The country surrounding it was low and arid, a desert almost, and I was shortly anxious to make further explorations. 


\section{A N D ACROSS PANAMA}

When I proposed to go along the coast of the Goajira Peninsula, and look up the pearl fisheries, my friends shook their heads. The Goajira Indians are dangerous people, and I have light eyes, a feature particularly distasteful to them, and, according to my friends, always rather in disfavour among the aborigines of the tropical America.

The Goajiras have been known to suddenly attack a person with light eyes, even when meeting peaceably for friendly barter. The cry is raised, "Eyes like a cat," "Let us kill it," and sometimes they do kill without further provocation.

But in spite of warning, I prepared my expedition, and we started late one afternoon from the city of Rio Hacha, launching a clumsy canoe through the low surf, and were presently making good progress along the coast under a light, favourable wind. When night came, the men said we would go on shore and sleep near some Indian houses that we could see a little distance inland. I asked if it would not be dangerous. "For you, yes," said the leader, "but with us you will be safe." So without further words the canoe was taken ashore, and we made our 295 


\section{AROUND THE CARIB BEAN}

way toward the Indian houses, where everything was now dark, except the smouldering embers of their fires. The moon was shining uncertainly through light, drifting clouds, all the country was silent, and the houses loomed up dark and mysterious above the flat, open ground of the plain. The men walked boldly to the village, I following, my head filled with the stories I had heard of the savage nature and cruelty of these Indians. Presently we were greeted by the united howling and barking of all the dogs in the place, and by the time we reached the houses a number of men had come out, with guns, knives, and bows and arrows in their hands. A word from the leader of my party, and grunts of satisfaction came from the Indians, who now began to look me over unpleasantly, but a few words of explanation and they seemed satisfied. Then they talked for awhile with my men, gave us fresh water and fire-wood; and with these we went away, made a camp on the beach, and slept as if there was no such thing as an Indian.

Very early next morning I was awakened to find everything on board the canoe, and the men ready to start again. We travelled until the sun became very hot, and then stopped for 


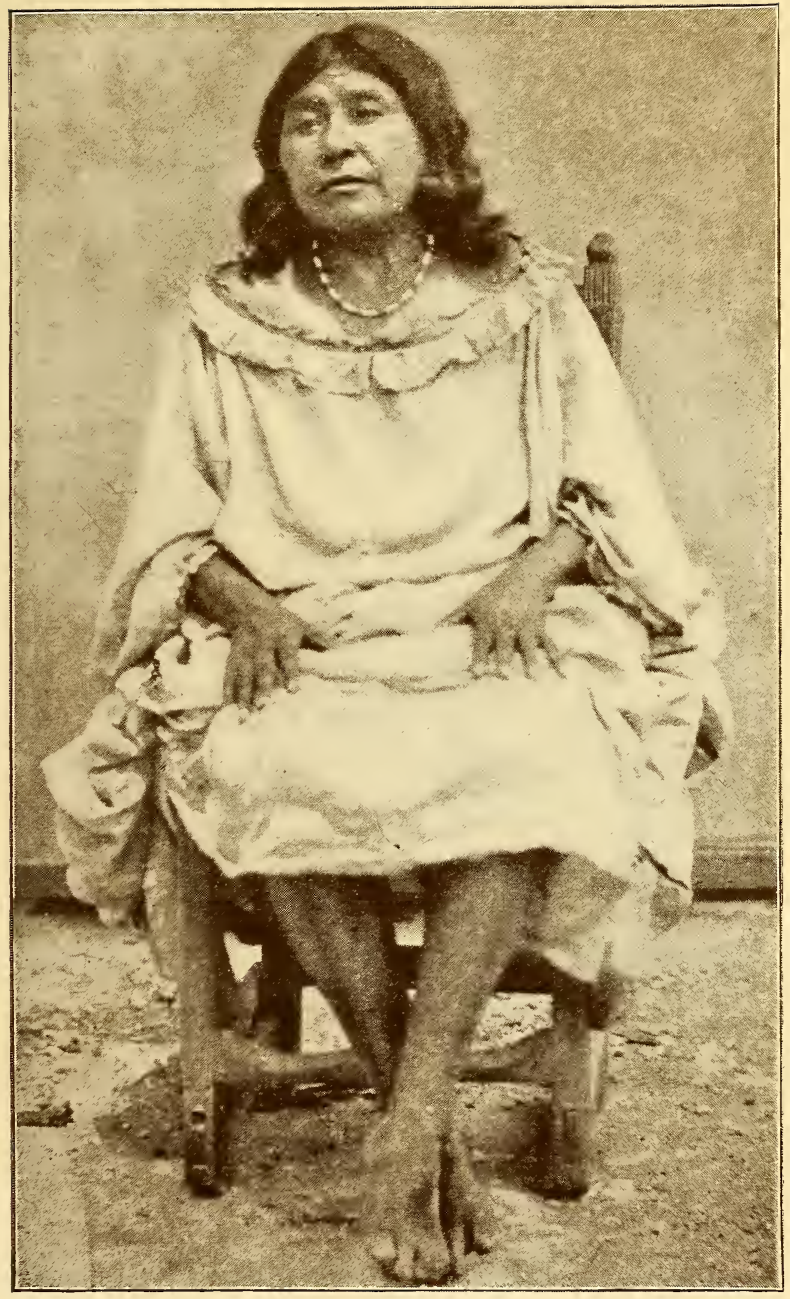





\section{A NDACROSS PANAMA}

breakfast at a convenient beach, where we expected to rest during the heat of the day, and then go on in the afternoon, camping again late at night. Where we stopped there were shallow lagoons covering considerable ground, desolate-looking places, but filled with quantities of herons, egrets, flamingoes, etc.; the different colours, brown, gray, pink, and white, standing out in sharp contrast against the dull water of the lagoon. I began to explore about, but the men objected decidedly, saying that if I went out of their sight I did so at my own risk; and as to their going with me, it would do no good; they had no control or influence over the Indians living near by; that they were a bad, dangerous lot; and, if any came along, we would take to the canoe, and go on our way. With such a recommendation for the place, I was naturally careful, though I wandered around a little, and did not see even the sign of an Indian. After a time we went on again, continuing for two days without incident till we came to the place where the Indians dive for pearls. Here we went on shore, and waited. There was nothing but a trail and two canoes drawn upon the beach to mark the place. After waiting 297 


\section{AROUND THE CARIB BEAN}

some time, I wanted the men to go call the Indians. They said that it would be no use; that the Indians had seen us coming and would come themselves just as soon as they were ready, and not a moment sooner.

About an hour later we saw a man coming down the trail, and then a little time more, and about fifteen to twenty men and women had gathered around us. After they had talked awhile, my men said that they were satisfied, and would bring me specimens of pearls in a short time.

Then two of the Indians went out in a canoe and began to fish, the others sitting indolently about. I wanted my men to urge them to begin diving for pearls; but they told me that the Indian law of hospitality required that they should make me a present first, and so I had to wait. Presently they came in with a basket of fresh fish, which was duly presented to me, and then all the Indian men took to the canoes, and began vigorously diving for pearl shells.

They worked with great energy but without system, each man for himself. Whoever happened to be in the canoe used the paddle without regard for those who were in the water, 


\section{A NDACROSS PANAMA}

yet, as they were not diving to very great depth, none had to swim far to overtake the canoe, and all seemed contented.

The canoes were paddled along very slowly, the naked Indians peering over the sides seeking to distinguish bunches of pearl shells clinging among corals and marine plants.

The Goajiras are stalwart fellows of stocky build, with great chest development attesting their vigorous lungs, yet their diving was not remarkable; they simply splashed into the water. I have seen nany American boys who could do much better, though the continued work, diving again and again without stopping to rest, gave evidence of strength which few can rival, and I doubt whether any American boy could keep with the Indians, even though they did splash in more like big Newfoundland dogs than expert divers.

It was an animated scene - four canoe-loads of Indians, men of magnificent build, diving continuously into water blue as a clear sapphire and clear as an inland lake, the intense sunlight of the tropics casting a glare over it all, and causing iridescent reflections of blue to go shimmering over the water in sharp contrast 299 


\section{AROUND THE CARIBBEAN}

to the dull green of the grassy plains along the shore.

After some hours the Indians came in with a large quantity of the shells, and without further ceremony began opening them, which they did very skilfully, from time to time picking out a pearl and putting it in their mouths.

As they worked, they answered all my questions about the number of pearls they usually secured, the depth of water in which the shells were found, the size of the shells, and many other things.

When all the shells were opened, trading began. We had tobacco, sugar, print cloths, worsted, and such things. The Indians would bring a pearl, or perhaps several of them, and make an offer for exchange, naming the things wanted. Sometimes we took the offer and sometimes not, and when the things asked were not given, the Indians would go away a little distance, consult together, and in a short time would come back offering new combinations of pearls, and asking different things in exchange. When an Indian was successful in making a trade, the others looked on approvingly, but if not, his defeat was greeted with shouts and 


\section{A NDACROSS PANAMA}

derisive laughter. They were perfectly goodnatured about it, and kept on consulting together and offering till all their pearls were gone.

There was one Indian who had a rough pearl not worth anything, and too old and worn to be of any service as a specimen. He offered it again and again, but $I$ always declined it; and, finally, he wanted one cigarette for it, but even this was declined. Then he set up mimic crying, and made sport for all his friends, and especially for my men. When he had finished, he made me a present of the pearl, and I made him a present of a package of cigarettes, and we were both well pleased.

While the trading was going on, the women had cooked the pearl mollusks, and the Indians fell to eating greedily. I had never known that they were good eating, and asked my men if the Indians would not give me some. The request was not completed before they hurried to me with all I could possibly eat, and urged me to take more, saying that they did not know that a white man would eat them. I did, though, and found them very good, in flavour resembling an escallop, a little sweeter, and with a peculiar 301 


\section{AROUND THE CARIBBEA N}

flavour that left a harsh feeling in the mouth that was not exactly pleasant.

After the Indians went away, we travelled on for a time, and finally stopped at another place, where we slept on shore, but did not learn anything about the pearl fisheries, because the wind was blowing, and the Indians could not dive. Then we pushed on to the Cabo de Vela, and slept in the canoe till morning, the men saying it was not safe to land till we could see what was going on. There was considerable noise on shore that could be heard plainly, and the men thought we would probably have to return without seeing the Indians, but in the morning everything was quiet, and we went up to the landing-place, where there was a single house, and were soon made welcome. I exchanged sugar that had cost fifteen cents for a fat sheep, and we prepared to make ourselves comfortable.

Nothing could be learned about the pearls, and no specimens were to be had, because the wind was still blowing. I wanted my men to take me on further to examine a point of rocks, but they refused, saying they had come as far as had been agreed, and proposed to rest. 


\section{A NDACROSS PANAMA}

A number of Indians had gathered around, and, finding that one, an Indian boy, could speak Spanish, I made arrangements to have four of them take a canoe and go with me on to see the rocks.

The leader of my men looked aghast. "They will certainly kill you," he said. "I must go along, too, and yet I don't fancy the hot sun; better not go. I have brought you here, you are safe, and this is the end of my contract."

I looked at the Indians and liked their appearance, and said to the boy: "My man says you may kill me, but I think I can trust you." The boy translated, and the Indians looked pleased. My men, seeing that I was going, gave a groan of protest, and prepared to follow me; but I would not have it, and proposed to go alone with those Indians, and I was not disappointed in them. Whatever I wanted to see, and in all that $I$ wanted to know, they were ready to do their best for me. After I had seen the pearl banks as well as we could, and had visited their fishing-grounds, I asked to be taken out beyond the point to where some great waves were breaking about a series of detached rocks, and thousands of sea-birds were constantly com303 


\section{AROUND THE CARIBBEAN}

ing and going. The boy translated my request. The Indians looked at the rocks doubtfully, but presently began paddling slowly toward them. As we drew nearer, they seemed to gain confidence. "Nobody hear," said the boy, "we can go on," and presently we were riding the great waves just outside the circle of foam, where they dashed against the rocks. Then from behind one of the rocks came three canoe loads of unfriendly Indians. They were intent on fishing, and did not notice us at first. "Keep still," whispered the boy, " and we will get away behind the rocks." Immediately the Indians saw us. "Go forward," I said, making a violent gesture with my hand, to indicate the way I wished to go. The men obeyed immediately; perhaps they thought that I had some special means of defence to be so confident; but, in truth, my heart was beating the wrong way from fright; sometimes up in my throat, and again down in my boots. A moment of suspense, and the canoes came together. I stood up, looked the men over gravely, asked to see their fish, and told the boy to buy some for me, which he did. Perhaps my apparent confidence impressed them, and for a time we floated lazily 


\section{A N D ACROSS PANAMA}

on the waves, I keeping them busy answering questions, and presently, while we were still interested in each other, I motioned to my men to go on, and they obeyed immediately. For a moment or two the other Indians watched us intently; then they went quietly to work again fishing, and the danger was over.

I asked the boy to take me on shore, where we walked about a little examining the rocks and getting specimens. The Indians would not let me go far from the boat, saying that across the ridge they had enemies, and it would not be safe. Soon I had all the specimens I wanted, and we went back to the canoe; and after paddling about a little more, went over to the hut again, where my men seemed much relieved at our coming. I paid the men in sugar, fifteen cents' worth to each, and gave the boy a string of beads with his share of the sugar. He was much pleased, but presently came and asked me gravely if I would allow him to give the beads to his little sister, as he had a string for himself, and then he added, apologetically: "The beads are a suitable kind for girls, but not for men." I was surprised to find such sensibility and honour in an Indian boy, and gave 305 


\section{AROUND THE CARIBBEAN}

him two other strings of beads for his little sister, and a bright-coloured handkerchief for himself, which was quite suited to a man's use, and he was well contented.

Presently he came running up to me, saying that his father would be willing to sell him, and wouldn't I like to buy him for myself; and he began telling me all the work he could do, and how well he would serve me; but I could not take him, and he was deeply disappointed. Perhaps I made a mistake. He was a strong, well-built lad of fifteen to sixteen, and a faithful, daring companion, such as he promised to become, cannot often be found.

A few days later I returned to Rio Hacha and then went on to other places. 


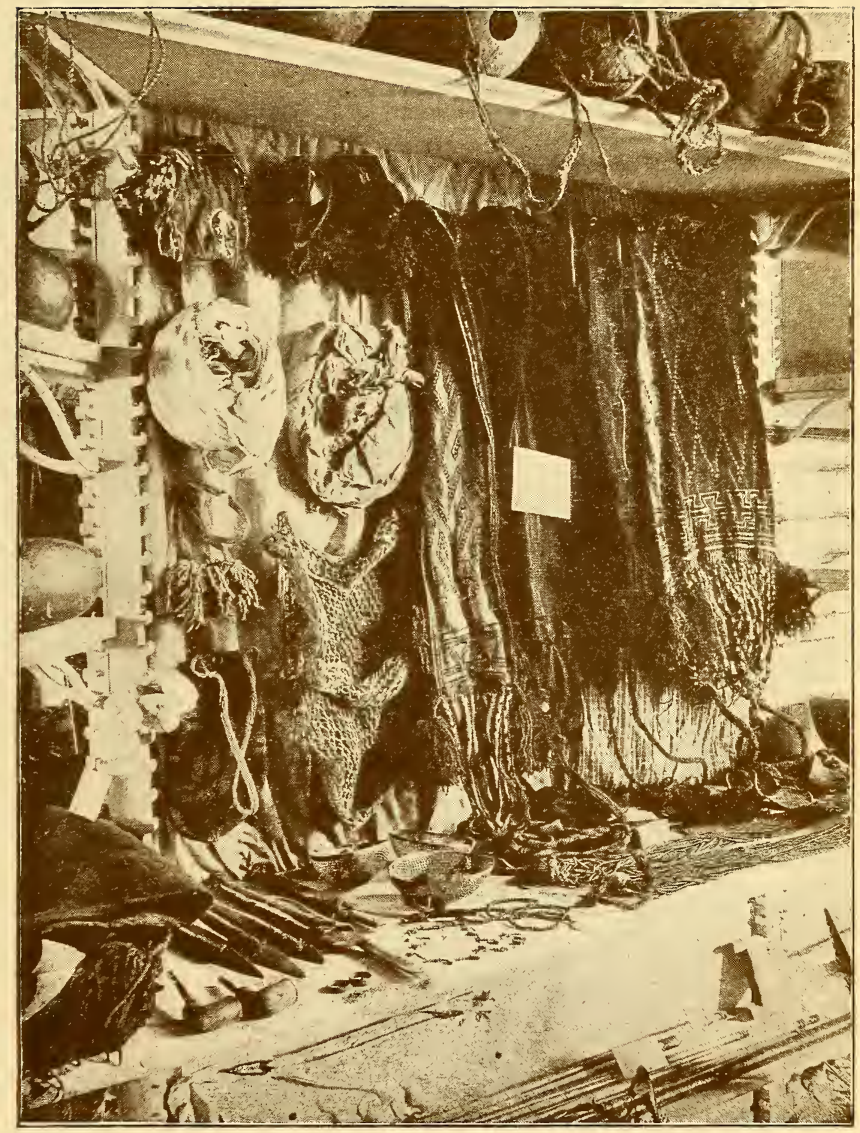





\section{A N D, ACROSS PANAMA}

\section{CHAPTER XXVII.}

RAMON, A STORY OF THE GOAJIRAS

After a short rest, I was ready to set out again, and went to make a brief study of a series of coal deposits about fifty miles south of Rio Hacha. There I became acquainted with a family of Indians, from whom I learned rather an interesting fragment of tribal history which seemed worth recording. I heard the story in disconnected portions, while the Indians told me of causes and dangers which had forced them to flee from their own country, and seek refuge in this distant place. To make the account intelligible, I must first give some details of their every-day life and tribal organization.

The Goajiras are different from most of the South American Indians, and more resemble the sturdy aborigines of the north; there is a vague legend among them that many generations ago 307 


\section{AROUND THE CARIBBEAN}

their people came from over the sea, and conquered the country. They are divided into clans or castes, and again into families. The clan relationship is not very strong, but the family ties are rigidly maintained, and to offend one member of a family is to make enemies of them all.

Unfortunately, they are of a quarrelsome nature, bloody contests are frequent, and sometimes whole families are exterminated. One could write much in regard to the customs of these Indians, but, as I am writing of adventures only, I will tell only what I heard of one of their fights, filling in some of the details, because the story was but imperfectly told to me.

The names of the clans only are given, but I do not wish to convey the impression that these Indians war with each other according to clan or caste, for this is not the case; their warfare is generally among families, though frequently the fighting will assume quite serious proportions; and two villages, representing different families, will sometimes fight till one or the other is destroyed utterly. Their quarrels principally originate through their eagerness to possess a number of wives. Among them 


\section{ANDACROSS PANAMA}

a man is estimated for his inherited wealth; to have made money gives only inferior prestige, but there is a certain amount of importance attached to the possession of a number of wives, and a leading man among these Indians will maintain as many as he can. To secure wives, however, he must be successful beyond the average. One wife is easily obtained, but to have more is something of an achievement. In the first place, when a Goajira Indian marries, he is required to provide an endowment for his wife, which must be paid in advance to her uncles, who put it out in cattle, to be carefully kept on the range till such time as the wife is divorced, or becomes a widow; then the property is turned over to her and her children, with the increase, and it usually amounts to a considerable provision. A Goajira Indian who desires to marry must not only be acceptable to the girl's family, but the endowment he provides must be sufficient to support her and her children in the condition to which she was born. Having once provided for the wife and her children, in advance, he can divorce her by simply directing that she take her property and go home to her mother; a woman then feels herself disgraced, 309 


\section{AROUND THE CARIBBEA N}

and this serves to make them careful, and their domestic relations are well ordered, though the men have the most absolute authority.

The strength and position of a family is increased by the number of wives provided for among them, consequently those who are enemies try to prevent marriages, while those who are friends endeavour to promote them; and the man who is to be married must have the courage to contend for his wife, as well as the position to make him acceptable, and the means to provide for her.

The Puinee are one of the strongest, as well as one of the most cruel, of all the castes of the Goajiras; and when Lorenzo, son of Lorenzo, the Chief, proposed to take to himself a second wife from a family of the Muichagua caste, belonging to a powerful village to the westward of their country, the men of an Uriana village, living between these two, determined that it should not be allowed; for these Puinee and the Uriana villages had been at enmity, even in the times remembered by the oldest Indians.

The Muichagua village was some distance from that of the Puinee, yet Lorenzo went and made all the arrangements among his new 


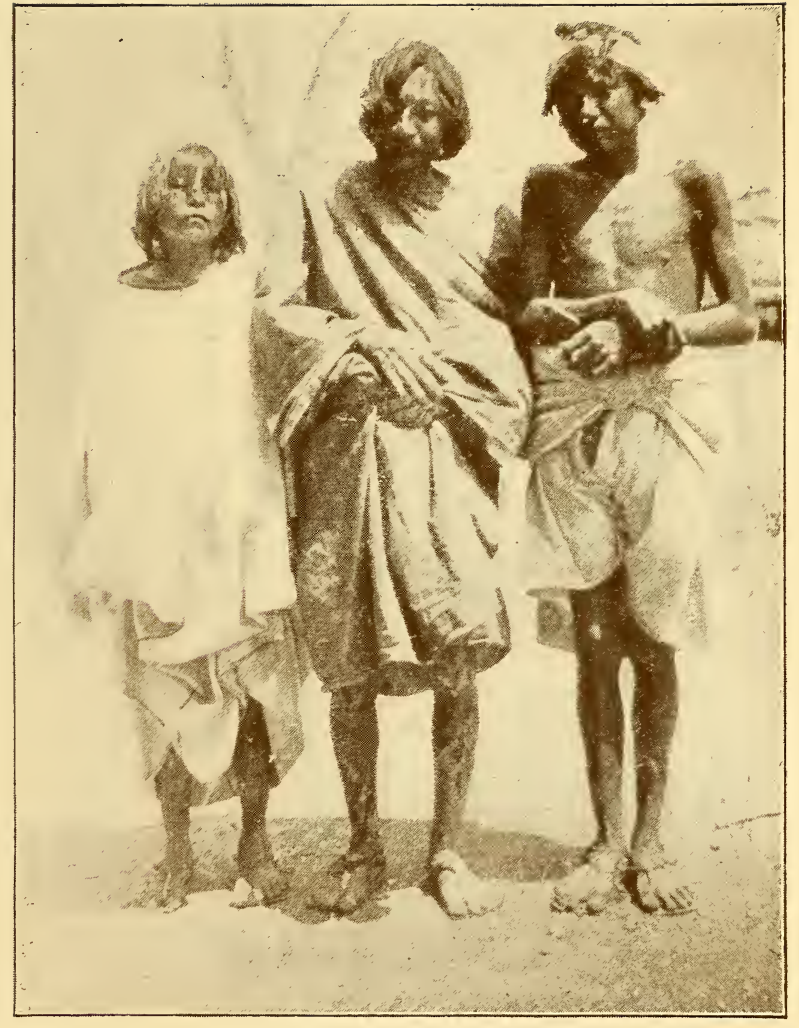





\section{A N A A ROS PANAMA}

friends, and then returned in safety to receive the congratulations of his own people. Then he went a second time, successfully passing all the Uriana villages, and returned again, and in his village there was more rejoicing because Lorenzo, the younger, gave promise of equalling the daring and cunning of his father, Lorenzo, the Chief.

But the men of the Uriana village were still to be dealt with, and did not remain idle. "What can Lorenzo want of his second wife before he is twenty years old?" they said.

"We must kill him or the girl," suggested one of the younger men.

"No, blood for blood, that will make the Muichagua village our enemies."

"But they will be our enemies as soon as she marries Lorenzo."

"Yet, if we can kill Lorenzo, it will not be 'Let him take a wife in his own village, and not increase our enemies.' The Muichagua village cannot lawfully avenge his death till after he is married. We must kill him first."

This was the counsel of the older men, and so it was determined. Yet how? Lorenzo, the younger, was a dangerous man, and the Puinee

311 


\section{AROUND THE CARIBBEAN}

village was strong. Finally, it was decided that Ramon, a daring member of the Uriana village, should go to the Muichagua country, and wait for an opportunity to meet Lorenzo, the younger, when he went again to see his intended bride. Ramon had two wives and two sons; one a rather stupid fellow of about eighteen, and the other, a boy of twelve or fourteen, straight as an arrow, and as wicked a little Indian as ever ran naked over the plains of the Goajira country. Little Ramon was all excitement, and wanted to go with his father to help kill their enemy, but he had to content himself with helping to prepare the poisoned arrows, polishing his father's stout bow, and carefully oiling the string.

Ramon was shortly prepared for his undertaking. His long hair was smoothed out, and a plaited band of straw, like the rim of an unfinished hat, was placed on his head, with a long red feather from the tail of a macaw standing exact at one side. He wore a string of coral beads, and among them hung three bullet-shaped charms made of red quartz, and known among the Indians as tumas; these tumas are of various designs, and are found among 


\section{AND ACROSS PANAMA}

the ancient groves in the Sierra Nevada de Santa Marta Mountains to the westward of the Goajira country, and certain rare shapes are prized by these Indians beyond any other of their possessions.

Ramon owned three of the bullet-shaped type, and wore them with great pride. Besides the beads, he wore a knitted belt of red and black worsted, which held a narrow breech-cloth in place; otherwise he was entirely naked. A bunch of poisoned arrows was thrust between his belt and skin on the left side; and with a stout bow in his hand he set out, followed by a slave who carried a bundle containing two robes of fresh white cotton embroidered around the edge with red worsted.

There was little ceremony of leave-taking, and Ramon was soon striding over the open country toward a thick group of tall cactus plants, and then on into a grove of acacia and divi-divi bushes; and after about half a day's travelling he arrived at the Muichagua village. As he went in among their houses, there was a loud barking of dogs; children ran screaming to their mothers, but Ramon walked on calmly unconcerned. He was not exactly among ene313 


\section{AROUND THE CARIBBEAN}

mies, nor were they enthusiastic friends; yet he had nothing to do but go to the principal house, give his name and position, announce himself as a guest, and he was perfectly safe. More than this, everything that could be done was done for his entertainment; the law of hos-

- pitality demanded it. Whoever did him harm did harm to his entertainers also, and amid all the feasting there was no appearance of what was in the thoughts of Ramon, as well as in the thoughts of those who entertained him; but this much was certain, no Puinee nor Uriana man could fight in the Muichagua village while both were guests.

Meantime, Lorenzo, the younger, was expecting trouble. The Puinee are noted more for cruelty and cunning than for valiant achievements, yet when they are in battle none are more daring. It was natural to suppose that their enemies would be preparing mischief, and Lorenzo was anxious to take a body of men and attack their village, so as to force them into acquiescence; but Lorenzo, the chief, was growing old, and was more averse to open conflict than ever. "Kill an enemy whenever you can 


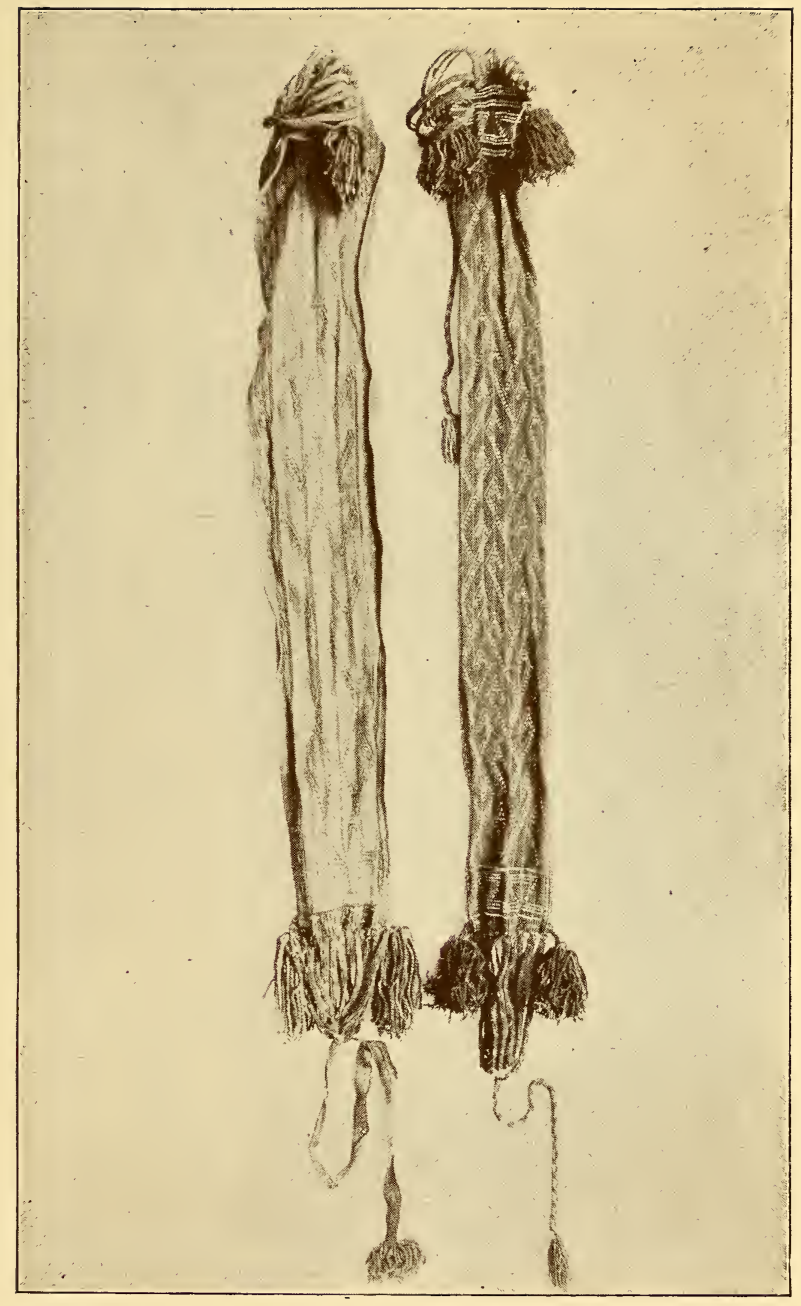





\section{A N D A R OSS PANAMA}

catch him." "We are killing more of them than they of us." "Let it go," he said.

But Lorenzo, the younger, was not contented, and he determined to lay a trap for some of their Uriana enemies. So calling one of his slaves, he bade him go to the Muichagua village, deliver a message at the house where his intended wife was living, and return. Then Lorenzo secured the assistance of ten of his friends, telling them that he was sure that their enemies were watching the Muichagua village, and would follow to attack his messenger while he was returning; not while he was going, because that would be an offence to the Muichagua village. The messenger was a good runner, and could probably keep well ahead of his pursuers, that is, unless they were mounted, of which there was small probability; and it would be an easy thing to kill some of them, as they passed by, intent on catching the messenger; then, with a part killed, the others could be easily overcome and disposed of. This plan suited Lorenzo's friends, and, sending the messenger on ahead, they cautiously followed, and in a few hours had hidden themselves among the acacia and 


\section{A ROUND THE CARIB BEA N}

divi-divi bushes along the road to the Muichagua village. There they waited.

Ramon was quietly enjoying himself when the messenger appeared. With true Indian indifference, much resembling that of the North American Indians, they looked at each other, and then went on with their own affairs. But in a few minutes Ramon got up and announced his departure, returning thanks for the hospitality he had received, and without more words walked rapidly away. The slave saw him go. and was alarmed, yet he was partially of good blood, and after considering a moment determined to make a bold strike for rank in his village; and, having finished his errand, started immediately to follow Ramon, but his adversary had disappeared. The slave looked cautiously about him while following on down the trail, and after a time came in sight of the acacia bushes where his masters were hidden. Then over toward the south country he saw three crouching forms following after him. He knew it was the enemy, and his first thought was one of exultation at the opportunity of distinction; he would fight them all; but if he had been endowed with the courage for such a conflict 


\section{AND ACROSS PANAMA}

he would long ago have won a place as the equal of those he served. For a time he stood his ground, but as the crouching forms drew nearer, he began to think that three to one was a too dangerous combat, so the next instant he took to his heels, and fled down the trail, his enemies following him, with Ramon in the lead.

On they came directly into the trap. The messenger ran past his friends without even knowing of their presence; then came his pursuers, and instantly a flight of poisoned arrows from among the acacia bushes came singing among them. There was no time to escape. Three arrows struck Ramon, and he fell forward on his face, tried to rise, but sank down again on his side, writhing in the agony of a poisoned death. One of the men was slightly wounded, and his end would be the more terrible. The other escaped, and with his wounded companion hurried toward their village.

Then Lorenzo and his friends, seeing whom they had killed, gathered around the prostrate form of their enemy with cruel shouts of delight, and gave no heed to the retreating foe. Ramon knew that his end had come, and he closed his lips and made no plea for mercy, for it is not 317 


\section{AROUND THE CARIBBEAN}

known among the Goajira Indians. All his frame trembled with the agony of the poison. He was going fast, and as he died Lorenzo set one foot in his face and derided his sufferings. Then in a little while it was all over, and Lorenzo's party started in haste for their own country.

Meanwhile the Uriana men who had escaped spread the news of the death of Ramon, and his people, wild with passion, started at once in quest of vengeance. Lorenzo expected this, and hurried on toward his own country, but when they had nearly reached the barren hills that marked the beginning of their lands they heard a company of horsemen following rapidly after them, and at least thirty mounted men, armed with poisoned arrows, were on their track. Lorenzo saw that there must be a fight, and made every effort to gain the first hills of his own country before it should begin, and in this he was successful. After passing over the first ridge he called a halt. Behind him he could see his pursuers, and must lay his plans quickly. $\mathrm{He}$ ordered two of the men to go over to the next ridge about three hundred yards distant, stop when half-way up, and wait till their ene- 


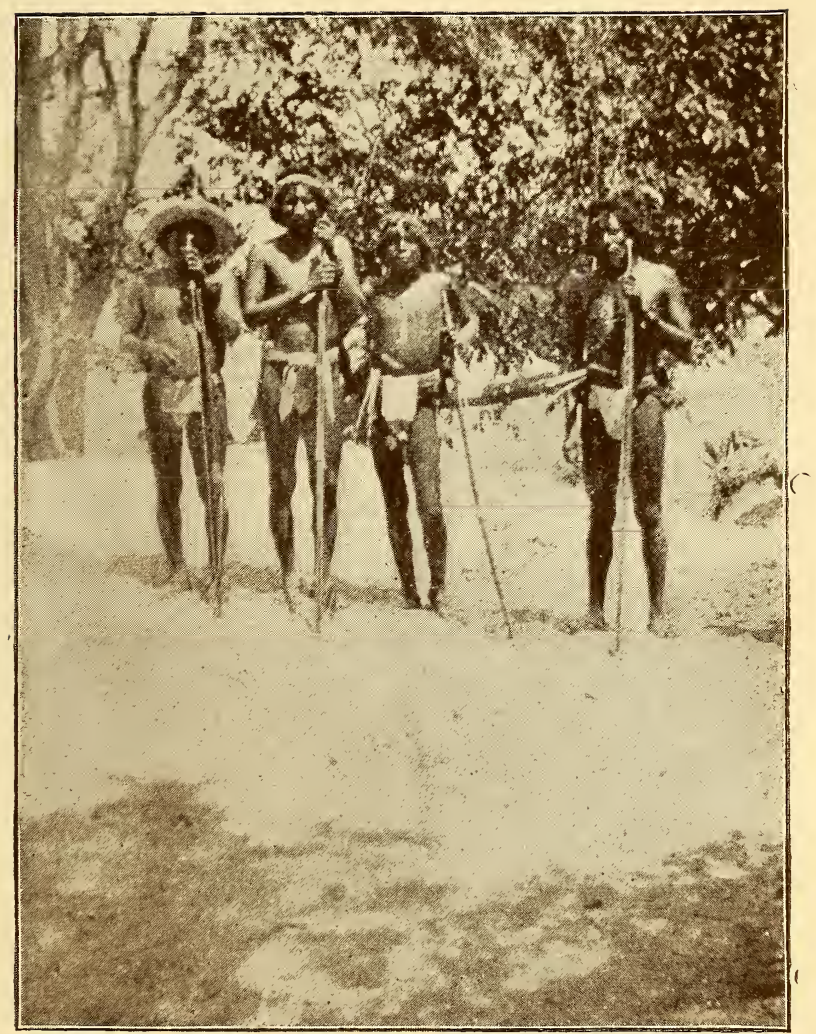





\section{A NDACROSS PANAMA}

mies came over the first hill, and as they came in sight, to begin struggling on as if completely exhausted. Then he hid the other Indians on each side of the road and waited. Presently thirty or more horsemen came over the crest of the first hill, and hesitated, as if doubtful about entering their enemies' country, even though they were mounted; but seeing the two apparently exhausted fugitives, they set up a cry of "Blood for blood," and started after them, sending a shower of poisoned arrows as they went. The two men gained the top of the hill, and, lying down to protect themselves, began to drop poisoned arrows among their enemies. This was not expected, and threw the pursuers into some confusion; and immediately from all around came poisoned arrows that fell with deadly effect. They were caught in a trap, and had no means of knowing with how many they must contend; but their thirst for blood was such that they crowded on, and killed the two Indians ahead of them; then, with many of their party wounded and dying, they turned along the crest of the hill, taking a little used trail for their own country. Lorenzo was not strong enough to continue the fight, so contented 319 
himself with such trophies as he could collect; these consisted of three strings of beads, each with a bullet-shaped tuma taken from as many dead enemies, and with the three taken from the body of Ramon made six most precious trophies. Lorenzo's people prized a different shaped tuma more highly, but these they had taken were the kind most valued by their enemies, and were considered trophies worthy of any fight.

Taking up their dead, they went directly to their own village, where the sight of the trophies and the bodies of the dead so inflamed the feelings of their kinsmen that even Lorenzo, the Chief, was ready for a direct attack on the village of their enemies, who now were most probably all in confusion. The plans were quickly made, and late that afternoon some forty men, naked except for a narrow belt and breech-cloth, well mounted, and armed with bows and poisoned arrows, were on the road seeking blood; and toward sunset three parties, into which the company had been divided, began to close in on their enemy's village. Little Ramon, son of the Chief who had been killed, was out with his mother among some cactus plants beyond 320 


\section{A NDACROSS PANAMA}

the village, to wrap his father's body in hides, where it would remain for a year or more, till the flesh had rotted away, after which the bones would be gathered up, washed, and placed in a clay jar, to be set aside with others of the family in some secret place. They had not succeeded very well, and were planning how to make the bundle more secure, when little Ramon saw their enemies while they were yet some distance away. Quick as thought, he hid his mother in a dry gully, and then ran to give the alarm. A shower of arrows was sent after him, but he was too far away, and he ran on, reaching the village some distance ahead of the enemy, and gave the alarm; but so many of the men were dying from poisoned wounds that there seemed little hope for successful defence. The women and children ran screaming to the thickets, only to be cut down as their enemies closed in on them. None were spared, except the younger children, who were taken to be brought up as slaves, and who were made to look on at the trembling forms of their parents and relatives, writhing on the ground as the poison burned through their veins in an agony of death. The invaders were everywhere successful. The 321 


\section{AROUND THE CARIBBEAN}

village made a brave defence, but its people were outnumbered, and it was not long before all were killed, but not without inflicting some loss on their enemies, and a number of the best men among the invaders lay trembling in the agonies of the poison.

But little Ramon was not among the killed; before the fight had begun he had taken his other mother and stupid brother down a small gully near the village to the place where he had hidden his own mother; after that he would have hurried back to help in the fight, but his people held him, saying he was far too young. Then while the combat was at its highest they all made their escape out through the gully to the bush country beyond, and as night came on they fled away in the darkness. A few days later they stopped at a remote place near the edge of the Spanish country, where their murderous enemies would probably never follow them. Here they were joined later by two or three men who had not been at home when the village was raided, and several women with five or six children who had escaped by hiding in the gullies. These were all that were left of a once prosperous Indian village. 


\section{A NDACROSS PANAMA}

The invaders after their victory returned triumphant to their villages beyond the Cabo de Vela. Here some days were spent in feasting on the provisions taken from their enemies, and then word was sent that Lorenzo would go in three days to take away his wife.

Preparations for this event were actively carried forward, and on the morning of the third day Lorenzo, dressed in new white robes embroidered with red worsted along the edge, with a fine collection of tuma beads hanging around his neck, a clean band of plaited straw about his hair, and a gaudy feather from the tail of a macaw standing erect on the left side, was ready, with a party of friends similarly dressed, to go and claim his wife. He had a number of slaves with him, and a fine herd of sixty cows which were to be the price or security for his wife. This was the highest provision required by their laws, but she whom he was to take was a person of quality, as well as an Indian girl of rare beauty.

The thirty miles between them and the village of the bride presented but little difficulty; the Indians were well mounted, while the cattle accustomed to running wild are easily kept at 323 


\section{AROUND THE CARIBBEAN}

a good pace. The company went slowly at first among the low hills and barren ridges of their own country, then more rapidly over the open plains where their enemies had lived, and finally came to the divi-divi bushes beyond which was the village they were seeking. Here they continued on, but at a slower pace, among the narrow trails that crossed and recrossed in every direction. At times they passed isolated ranchos, whose inmates immediately joined them, till the little party, now swelled to a goodly company, arrived at the village, where they were noisily welcomed. Then the provision and security for the well-being of his wife was delivered by Lorenzo, and received and taken note of by her uncles on her mother's side, who pronounced it liberal beyond all precedent, and of the finest young cattle. Then feasting began, while little parties of men, women, and children from the surrounding country kept arriving to join in the celebration, till a large company was gathered together. Then the chief man among the bride's people, who was also her father, said: "Lorenzo has provided well for the daughter of our village. He must not return emptyhanded to his own country; let him choose a 


\section{AND ACROSS PANAMA}

horse from among the best that we have." At these words the slaves ran and drove up a herd of thirty or forty horses, and Lorenzo picked out one, a well-built, steel gray animal that promised to do him good service. Then the chief said: "And the friends of Lorenzo, he will remember us better when he rides to battle if our horses carry his friends. Let him choose a horse for each of them." Then the eight or ten men who had accompanied him began to select from among the horses. It was a very businesslike transaction, but after active investigation under Lorenzo's direction it was completed to their mutual satisfaction, and feasting went on again. There was roast meat, curd cheese, parched corn, pearl oysters, fish, roasted meat, and a small allowance of tobacco and rum for each important man in the party; but only a small quantity, because these things were difficult to obtain. Then more presents were given to the bridegroom, and feasting was continued till everything was eaten that had been provided for them, and when it was evident that no more presents were to be had, the visitors gathered their things together, took leave of their allies, and marched off, the slaves driving 325 


\section{AROUND THE CARIBBEAN}

the new horses and carrying the presents. Lorenzo rode by his new wife, admiring her beauty, but also taking special note of five large tumas that she was wearing. It was well along in the evening when they arrived at their village, and as every one was tired all were soon asleep.

The next morning lazy Indians could be seen idling about the place, the women doing a little work, or picking lice out of each other's hair, the slaves tending the cattle, while most of the men were curled up in their little hammocks asleep, like animals. To all appearance they were a lazy, dirty, stupid lot of people, too indolent to ever think of rousing themselves or to do harm to anybody. This same morning, away off near the base of the Black Andes, the remnant of their enemies were gathered together looking to little Ramon as their coming Chief. It was a hard struggle for existence, but they did get along. They were out of the track of Indian parties, and near enough to the Spanish country to enable them to seek protection if they were discovered; but of this there was little danger, because their enemies belonged to the seacoast far away.

While I was examining the coal-mines of 326 


\section{A NDACROSS PANAMA}

which I spoke at the beginning of this chapter, my guide said, "There is a party of fugitive Goajira Indians living a little beyond here. Perhaps you would like to visit them."

I replied at once that I would, and asked how it was that they were fugitives.

"There was a big fight over toward the cape," he said, "and these people are all who escaped out of the party that got the worst of it. They are a bad lot, those Goajiras, and it's a pity that they don't keep on fighting till the whole of them are killed off."

We soon arrived at the Indian village, which consisted of three little, rectangular, thatched huts, made by driving posts in the ground. Our appearance caused some excitement at first, and one of the two men belonging there caught up a bow and bunch of poisoned arrows, but seeing that we came as friends the arms were laid aside, and we were made welcome.

Evidently they were poor Indians, and not very interesting; but there was a fine-looking elderly woman and a very pretty young girl. Presently, an almost naked boy of some fourteen years came walking gravely into the village. He carried a bow and arrows and a bunch $32 \%$ 


\section{AROUND THE CARIBBEAN}

of game that he had killed. He came at once to welcome us, handed the game to the elderly woman, went and put on a well-worn robe, and then coming to us again, stood gravely, but said nothing. He wore his robe with so much unassumed, quiet dignity, and was such a splendid boy, with muscles appearing as strong as steel wires, that I was interested in him immediately. Then he asked me what I had come to do.

I told him of the specimens I wanted, and his face lit up with boyish delight, and all his dignity was forgotten, as he eagerly proposed to accompany me, and show where I could find all sorts of interesting things.

His robe was quickly changed for belt and breech-cloth, and as he gathered up his bow and arrows, I asked why he did not take some of the long ones with slender black tips.

"Those are poisoned arrows," he said, and brought one to show me. I put out my hand to take it, but he drew back, saying, "It is best not even to touch it; the white strangers have thin skins, and the poison is strong."

Then as we went away toward the river, I asked him why he wanted so many poisoned arrows. "We have enemies," he said, "and 


\section{A NDACROSS PANAMA}

the time may come when we can gather some men together and use them. I want many, but they are hard to make, and it is slow work."

Then he told me how he had to search till he caught three of the most poisonous snakes: a rattlesnake, a coral-snake, and a golden mouth, a kind of moccasin; these were all shut in a clay jar till they bit each other to death. Then the cover was luted on with clay, and the jar was buried for fifteen days, and when the snakes became a putrid mass, with which the deadly poison from their fangs was mingled and fermented, the arrow-tips of bane or hard wood were dipped in it, and allowed to dry, and then redipped till they became coated with a poison so virulent that the least scratch would cause the most violent death. On the way out the boy, Ramon, stopped to show me a jar of the poison that he had under preparation. Then I asked him about the enemies he was so anxious to kill, and he told me the story that I have written, and as we walked along he showed me so much about the country that was interesting, and found so many specimens that $I$ wanted, that $I$ said, "Ramon, I wish I had a boy like you to work for me."

329 


\section{AROUND THE CARIBBEAN}

"Do you?" he answered, all eagerness. "Would you buy me, and teach me how to use a rifle against my enemies, and be wise like a white man?"

I explained that I could not buy him, but he still pressed the matter, saying, "I would not cost much, just enough for my mother to have till I came back all grown up. My brother and the working men could take care of themselves."

He would certainly have been a valuable acquisition, but it was quite impossible for me to buy him and become responsible for bringing him up; and he seemed so much disappointed that I told him to come and see me some day at Rio Hacha, where I expected to remain several weeks.

When we went away the Indians made us a present of vegetables and game, and the next day I sent them a handful of nails, a package of sugar, and a ball of twine. I heard afterward that they were embarrassed by my liberality.

About two weeks later I was sitting in my house at Rio Hacha late one night writing. My pistol was at my side, and the negro boy 


\section{A ND ACROSS PANAMA}

who attended my rooms had gone to sleep and was snoring vigorously. The little city was all silence except for low waves washing up along the beach, and I thought how lonely it was as I looked out at the dim moonlight reflected on the white sand; when suddenly the slender form of Ramon, the Indian boy, appeared at my window, scarcely disturbing the silence; then, with a gesture that bade me keep quiet, he came softly in and closed the door behind him. "I had to come at night," he said. "Some of our enemies from beyond the cape are in the city, and they would kill me if they could."

He had travelled forty or fifty miles on foot to see me. What a boy! I put him in my hammock, and went softly to get him something to eat, taking care not to disturb my negro servant, because it seemed best that none should know of my Indian visitor. He ate all that I had in the house, which would have been too much for an ordinary person; but a healthy, growing Indian has a capacity unlimited. Then he talked again of my buying him, earnestly entreating; but I could not do it, and told him how it was my business to go about among 331 


\section{AROUND THE CARIBBEAN}

distant countries, and he saw that it could not be.

Then he whispered, "There are men from beyond the cape in the city. I know where they sleep; we could kill them all." But I could not help him in this, either, and explained that the white men had different laws, and advised him that he was too young to even think of fighting his enemies, that they were too many for him, and even if he should kill some, the others would track him down, and that would be the end of his family. Then he became silent, and lay back in the hammock, while I sat beside him. He was near his enemies, but was too weak to attack them, and as he lay there his chest heaved, his eyes became more brilliant, and his lips rigid. He was sorrowing and grieving for his dead, not with weepings and lamentation, but after the manner of his people, with hate. I could see it burning in his eyes and throbbing in his temples; and what an allconsuming hatred it was! I became alarmed for the boy, and knowing how the Indians prized the red stone beads called tumas, I went to my collection and selected one shaped something like a conical bullet, with the hole drilled across 


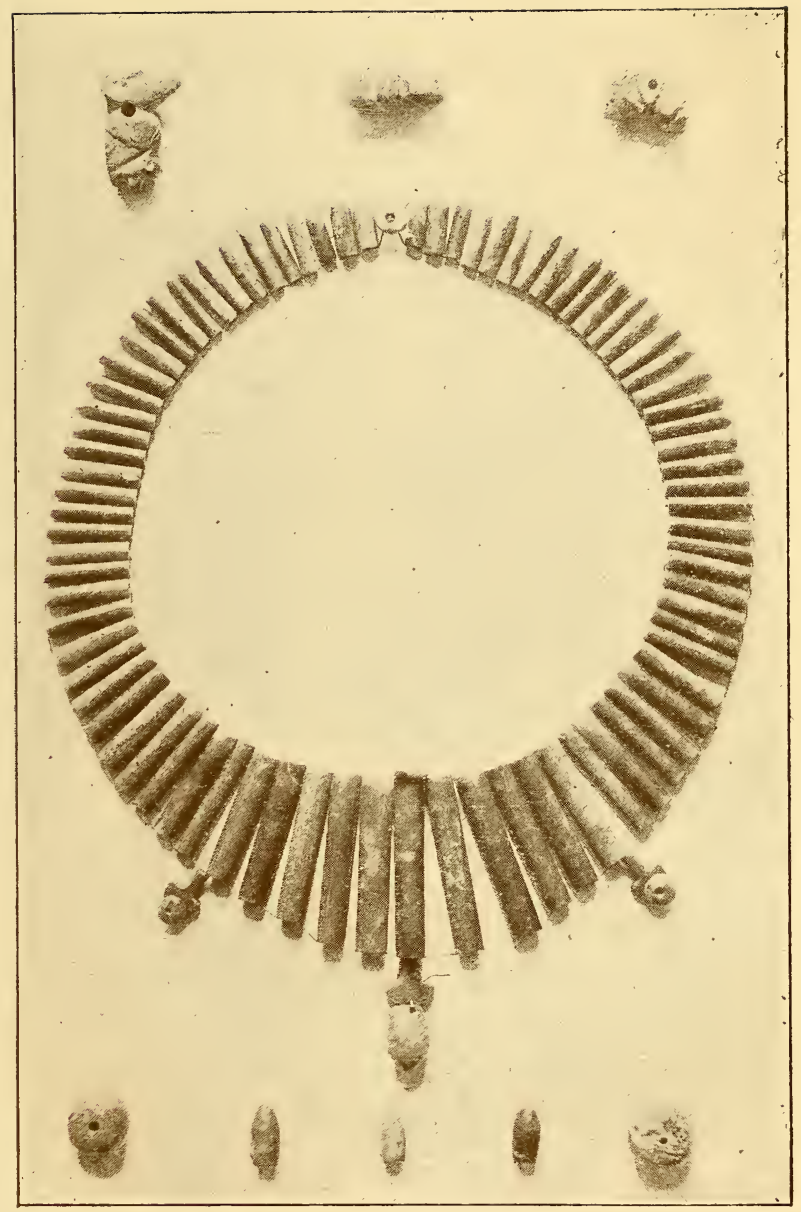





\section{A N D A ROSS PANAMA}

through the larger end. I gave it to him, and he was immediately all smiles again, but the next instant he looked at me with wondering eyes and said, "Señor, you could buy me with this. I cannot take a gift so valuable." I put a string through the bead and hung it about his neck, telling him to wear it in my remembrance. Then he said proudly that no one should take it from him while he lived, that it was the shape most prized by his family, and I would never need to be ashamed of him. The next moment he said that it was time for him to start, as he must be well on his road before his enemies were about.

"But, Ramon," I said, "it is night-time; think of the snakes, the jaguars, the panthers, and other dangerous things." $\mathrm{He}$ only laughed lightly at this, picked up his bow, shoved the arrows in his belt, and went quietly to the door, and I watched him steal softly out in the pale moonlight; but before turning away, he stood a moment looking back at me, only a half-naked Indian boy standing alone in the night. Then he waved his hand and was gone, and I said to myself as I closed the door, if ever he grows up his enemies will hear from him. Then I fell 333 


\section{AROUND THE CARIBBEAN}

to thinking of the strange life of the Indians, and how different their ways are from our ways, and their thoughts from our thoughts; and how soon they will all be gone, and how much of their lore and legends, their customs, and even their names will be lost, and for ever unrecorded.

I have a sequel to this story. I never expected to see Ramon again, but I did see him some four years later, when I returned to the country for other investigations. Ramon was a boy no longer, and the promise for a bright future had gone from him for ever. He was weak, he was diseased, a slave among the people he had hoped to vanquish. He was passing my door and stopped as if to speak to me, but a sharp order from his master, and he went dejectedly on; and as he went the expression of a drunkard was all too plain, evidence unmistakable in his face and in every movement, and the tuma he had accepted with such pride, that I should never be ashamed of him, it was gone; yet what drunkard has ever been able to maintain his honour? Looking after Ramon, deeply regretful, I kept thinking, Oh, the traders, the traders, why will they for ever take rum among 


\section{A NDACROSS PANAMA}

the Indians? And I could not help but think of a judgment to come, "when earthly things made even atone together," and to wonder what penalty those men should pay who for such a little thing, the profit on the rum that Ramon would drink, had destroyed a life of so much promise.

In this story the spelling of the Indian names is phonetic, adopting the sound so nearly as may be to the English language. I do not wish to convey the idea that the different castes among these Indians fight together and against each other as clans. The continued strife is between families and villages, without much regard to their castes, and among them to-day caste distinctions are dying out, though formerly they were strong. 


\section{AROUND THE CARIBBEAN}

\section{CHAPTER XXVIII.}

ACROSS . COUNTRY TO BOGOTÁ

I DID not remain long in Rio Hacha, but went again to the coal-mines, intending to go across the country after I had finished my examinations, and travel as far as Bogotá.

Where the coal-mines are located is a great valley between the Painted Andes and the Sierra Nevada de Santa Marta Mountains. The valley was intensely hot, low lying, and, at many places, stony and arid. At such points cactus plants grow to unusual size, and in such great abundance that they form a forest crowded so close together at some places that one seems shut in from all the world. Here there is no other vegetation, and the land is silent, the cactus plants stand motionless, the heat is intense; though in some places the growth is so thick, and the plants so tall, that the sun is shut out, 


\section{A NDACROSS PANAMA}

and a grateful shade is formed. Riding on through a forest of these great cactus plants, following a trail on its winding course through their crowded growth, the strange forms, the silence, the sharp contrasts of shadows and burning sunlight, and the cave-like surroundings where the cactus have grown over thick, give one an impression as of another world, or as if, in fancy, one were passing on through an unknown region of the ocean depths, so strange and so unreal it all appears.

It was a rough life in the valley, but the strange surroundings made it attractive, and here I tarried for some days. After a time I became interested in a peculiar mountain called the Cerrajon, an abrupt formation standing in bold outline directly above the valley.

The majordomo of my peons said it was not a difficult climb, but if $\mathbf{I}$ wished to reach the summit it would require two days, as we would have to cross to the other side of the mountains, then up the main range and along the top of a ridge till we reached a point from which it was an easy matter to climb the Cerrajon.

This did not suit me at all. I wanted to see if there was coal on the steep front of the 337 


\section{AROUND THE CARIBBEAN}

mountain facing the valley, and so informed the majordomo.

"It is impossible, señor," he said; "for birds and wild animals it can be, but it is not a place for men."

"But I want to go there, and I wish to find a way, and you must come with me," I said, angrily.

"I can go, but not to show the way," he said, adding, with a great show of politeness, "and if the Señor knows a path up the mountains, having never seen it, he can go to the top, and I can follow him."

We started early the next morning, walking about five miles through the cactus and thornbushes to the foot of the mountain. Here the real climbing began. We had crossed several smaller mountains on our way, and were thoroughly warmed to our work; yet it was a rough and tumble all the way to the top. We could never have reached it but for the bushes and small trees growing all over the side of the mountain; we went up bracing our feet against these very much as one would climb a ladder. Sometimes we came to places where even this was impossible, and the majordomo would say 


\section{A N D ACROSS PANAMA}

with satisfaction that we had reached the limit, but by making our way carefully along the face of the mountain, I always found a place where we could go a little higher, and we kept going up and up till finally we came to a ledge of rock that appeared unsurmountable; but we followed along its base for some distance, and finally came to a broken place where we had a rough scramble for a few moments, and then stood on the very summit.

The majordomo was delighted, and told me that we were on ground where no man had ever been, a place the people of the valley had always considered entirely inaccessible. The scene before us was most beautiful, appearing almost as if I could take one step out into space and go falling to the valley below. Across this valley I could see all the Sierra Nevada de Santa Marta Mountains, their bold outlines dark in the lengthening shadows, and their white peaks glowing with colour under the fierce light of the tropical sun.

I stood looking for a long while, till, finally, the majordomo reminded me that it was getting late, and camp was a long way off.

Going down was a good deal like sliding off 339 
a barn roof and taking your chances, but after many scratches and bruises we got down safely, and then began a hard march to camp, where we arrived about nine P. M., thoroughly tired out.

A big dinner was waiting, and after eating all I could, I went to bed; and as I fell asleep I heard the majordomo giving thrilling accounts of our adventures climbing up the Cerrajon Mountain to a point where he and his hearers agreed no human being had ever been before.

A few days more in the valley, and I started on a long journey overland en route for the city of Bogota. I followed the valley westward to where it opened out into the great basin of the Magdalena River, passing on my way a series of cactus plains, mud-holes, acacia thickets, and, at frequent intervals, fertile regions, marked by the presence of thriving towns. After travelling for two or three days, we came in sight of the precipices for which the Painted Andes are named. The cliffs stand in rugged outline at the highest portions of the range, their faces banded by great stratification of alternate black and white extending horizontally all along the front of these precipices, a formation so strange that it was startling, and so 


\section{A NDACROSS PANAMA}

bold and clearly formed that we could see the great bands of black and white for many miles of our journey, looking exactly as if they had been painted along the upper portions of the mountains. I was anxious to visit those strange precipices, but this was impossible, for they marked the country of the Matolony Indians, a tribe so murderously disposed that on meeting them one must either kill or be killed; no one had ever penetrated so far among their mountains, and guides could not be obtained.

Two days further on, one begins to encounter the swamps and lagoons of the Magdalena valley. On reaching that country I travelled mostly by canoe, and found the lagoons interesting, though of a dreary appearance, oppressive, blighting almost to one's spirits. I went over this country with some care, and examined many of the streams flowing into the Zapatosa Lagoon, the largest of all the interior lakes of Colombia.

There were no particular adventures, and everything went well with me till one afternoon when we stopped for the night at a little village. There my two guides promptly became intoxicated, and next morning they were in a

341 
bad condition to continue the journey; in fact, they were very drunk. I was told that, once in the canoe, they would take me safely enough; the only difficulty would be to get them started. After some effort I succeeded in getting them in the canoe, though one of the men tumbled over the side while attempting to take his seat. We had a long trip before us, and the undertaking appeared rather dangerous with the two drunken men in a canoe that would turn over so easily that a person had to be careful and sit quietly all the time.

The men did fairly well, though they would often fall asleep over their work and nearly upset the canoe, but somehow they would always catch themselves just in time. We kept going on and on, now through a narrow channel, then out into a broad lagoon, or among a cluster of low, unhealthful islands, till finally we came to the great Zapatosa Lagoon.

The men were tired now, and wanted to stop, saying that the weather looked threatening, and that a storm on the open lagoon in so frail a craft would be certain death.

I thought that my men were more anxious to stop for the night at a little village we were 


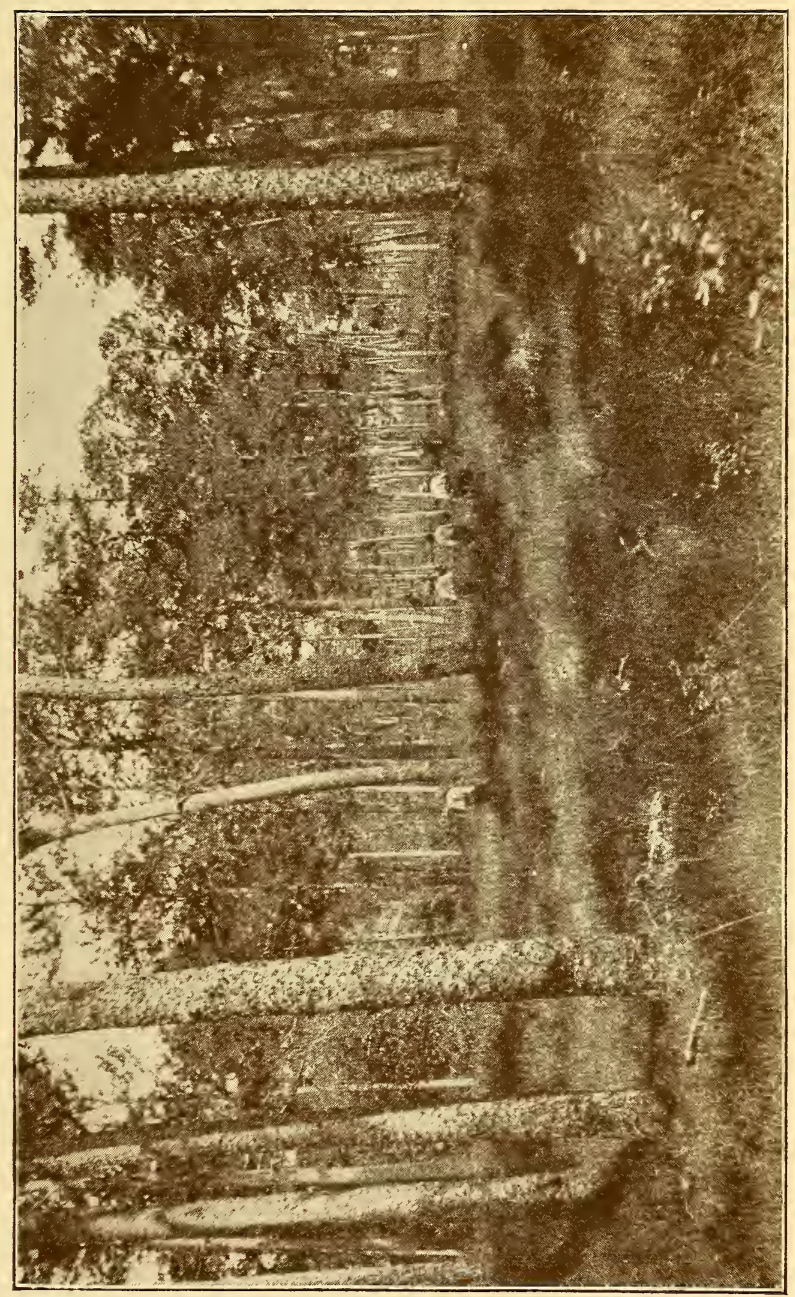





\section{A NDACROSS PANAMA}

passing than they were afraid of a storm, so I determined to push on, and presently we came out on a broad lagoon so large that our eyes could scarcely see across it, while in the distance ranges of mountains appeared as floating in the air above the water.

Over the surface there was silence, and everywhere a sense as of death; the yellow water was glassy in its repose, the intense, refracted sunlight adding to the illusion. In the unhealthful-coloured water were dead trees, groups of alligators, and here and there companies of aquatic birds. Along the shores there was desolation, dead trees, and struggling cane-brakes. My men forgot their laziness; they were working now with the energy of fear. Swiftly the light canoe went forward, but there was no breeze, nothing to relieve the intense heat, and such a burning heat; it seemed at times as though I could scarcely breathe. As we went on, I could understand the fears that the men entertained of this treacherous water, and in fancy I imagined the wild tumult of a sudden storm sweeping over that desolate lagoon. Suffering intensely from the heat, we pressed on, and after an hour or two had crossed a sort of 343 


\section{AROUND THE CARIBBEAN}

bay in the lagoon, and then we came in the gathering darkness to a river, and on its black waters we were carried away into the night, till presently we came to a hut, and were soon asleep.

The smaller lagoons are similar to the Zapatosa Lagoon, and of them there is little to be said. I continued some days in this region, making explorations, but without special incident, and then went on my way, following the trails to the Magdalena River, and then, taking a steamer, went up the river again as far as Honda, and from there $I$ went across the mountains on foot to Bogota.

On the road across the mountains there were no exciting incidents, only annoyances; the way was tedious, the people inhospitable, the road-houses unclean, and their charges little short of robbery.

Bogota is on the eastern side of a great interior savannah, an open grass plain at almost ten thousand feet elevation above the sea, a place of enchanting beauty, a broad expanse of open country surrounded by the bleak summits of inner ranges of the Andes Mountains. But the city is a place of vermin and corrupting 


\section{A N D ACROSS PANAMA}

filth; a place where the common incidents of the streets are not fit to be described; where beggars, displaying revolting sores and rotting limbs, swarm about, even thrusting their filthy bodies where they may touch those who pass by, while they demand, not solicit, alms; where ill-mannered, arrogant, overdressed people make vulgar display of their clothes, as they strut about and crowd for precedence, making much of the antiquated custom of demanding a place next the wall, - a fad which caused continued misunderstandings, because all claimed the wall, and it was difficult to pass; for my part, I walked mostly in the streets, and left the sidewalks to the natives. In Bogota one can see the sedan-chairs in active use, similar to those which are read about in historic accounts of periods some two or three centuries gone past. Here ladies, to show their piety and religious sentiment, go about dressed as penitents in rough garment and belt of rope; but the dress is drawn tightly about them, that they may not touch the swarms of filthy people.

One incident of the streets is ever vividly before me. I saw a boy, ragged and dirty, his hands tied firmly behind his back, his head a 345 
mass of sores, scabs, and filth from the lice of Bogota, called peojos by the natives. He was whimpering and crying, screaming at times in his distress. With his hands tightly bound, his parents led him about, soliciting alms, their hard faces showing too clearly that they were making a medium of the boy's sufferings to obtain money for themselves. I looked on in horror for an instant, and then asked some people with whom I was talking that they would excuse me for a moment, in order that I might give some money, and prescribe an ointment by which the boy could be cured. They laughed derisively, saying that I might give the money and the medicine; the parents would call down blessings on my head, but they would keep the money and sell the medicine, - the boy was too profitable for them to permit a cure. I hesitated: the blessings from such fiends would be more blighting than the deepest curses from decent people; and as I hesitated, the boy gave a convulsive tug at his bonds, freed one hand, and immediately clutched at his itching, burning head, dragging at it with such violence that a great patch of his scalp was torn off, exposing the skull. His parents bound his hands again, 


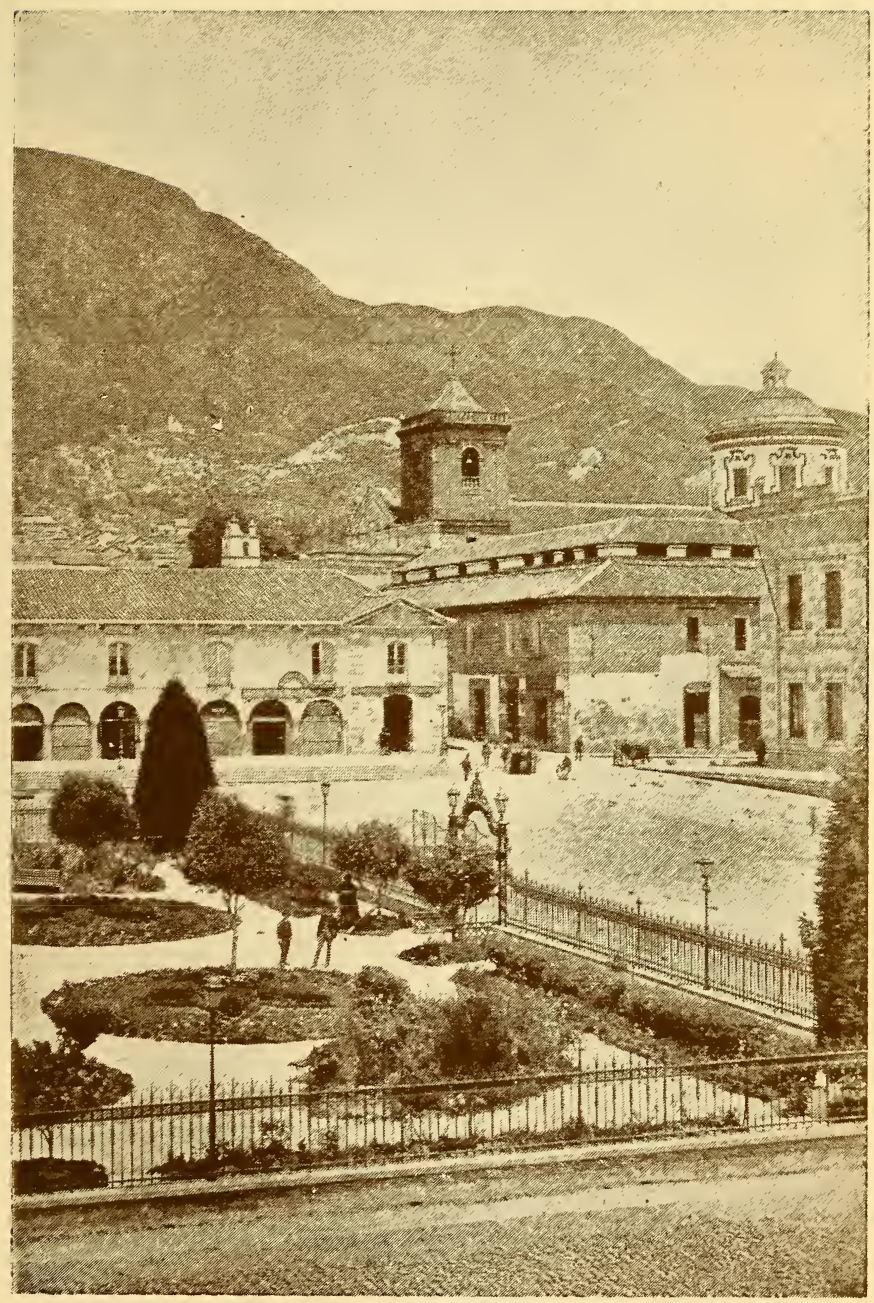





\section{A N D ACROSS PANAMA}

and with cruel looks of satisfaction led him on, blood dripping over his face, his cries of distress and the plaintive whine of his parents, as they asked pity for their misfortunes and the necessities of their suffering boy, adding horrid emphasis to his appearance of misery. The religiously-gowned ladies drew their garments close about them, and looked aside that they might not see; their great houses were closed tight, and walled about; it was nothing to them; what did they care? How I longed for the Society for the Prevention of Cruelty to Children. But $I$ was a stranger in a city where I was quite unknown, and found but scant courtesy in ordinary affairs; what could I hope to do for a suffering boy, where the law made no provision, the citizens of the place gave no heed, and all the streets were filled with scenes of filth, misery, and degradation.

Naturally I had but little desire to remain in the city, and finding the country people goodnatured and trustworthy, I made frequent excursions among the surrounding mountains, and out on the beautiful plains of the savannah.

One morning I climbed the highest peak back of the city, and then made my way to still higher $34 \%$ 


\section{AROUND THE CARIBBEAN}

elevations some distance further on, and there I ascended a peak which just penetrated the frost line, and found ice collected on its summit. Here was absolute solitude. For miles, north and south, were successions of elevations and ridges forming the interior ranges of the Andes Mountains. There were patches of red earth exposed on eroded surfaces, outcroppings of disintegrating rock, in colour a dull yellow, blending with the cold grays, dull browns, and doubtful green of the stunted vegetation; a great expanse of country, alone and desolate. The shadows of drifting clouds were in the air, a dusty haze hung over the distant ranges, and the sunlight seemed feeble, not strong to cheer. Damp cold was all over the mountains, a place of broodings and melancholy thoughts, of loneliness and chill; but on the protected places below the rocks there were flowers, soft, delicate blossoms, profusely blooming, little gatherings of joyousness and beauty, surrounded by the solemn expanse and desolate impressive silence of the unpeopled interior mountains of Colombia.

I remained a long time on this mountain peak, and then noticing a collection of huts on a 


\section{A NDACROSS PANAMA}

table-land not far below it, I went down to them, asking permission to remain for the night; a request the humble proprietors readily granted, though they were distressed as to how they might entertain me, for with them bread and meat were rare luxuries; but on finding that I knew how to eat roots, as they expressed it, we were soon quite at ease. For supper there were yams, potatoes, carrots, and onions; that was all, but it was enough; and that night, with my cloak wrapped tightly about me, I slept under an open thatched shed in front of their huts, the damp cold of the night blowing in my face, and the silence of the mountains enveloping all about me.

Next morning I went on again, after liberally paying my friends for their attentions, for they were too poor, I knew, to extend hospitality unrewarded. To the southeast of the table-land there was a range of mountains, some distance away, but I crossed over to them, and, climbing up over the summits, came to the divide, where the streams turn east; and a little further on there opened before me a view of all the plains and lowlands of the headwaters of the Oronoco, spreading out in the distance even to the far349 


\section{AROUND THE CARIB BEA N}

thest horizon. Here I rested for a time, and then turned again toward Bogota, not crossing the mountains, but following the trail across the table-land, which led to the city by easier gradients.

Shortly after this incident, I left Bogota, making a second journey on foot across the mountains to the Magdalena River, a difficult undertaking, but richly repaid in specimens of interest and valuable information; for $I$ was investigating the probable cost of railway construction. I was not sorry, however, when I was once more on board a steamer on my way. down the river, en route for other places. 


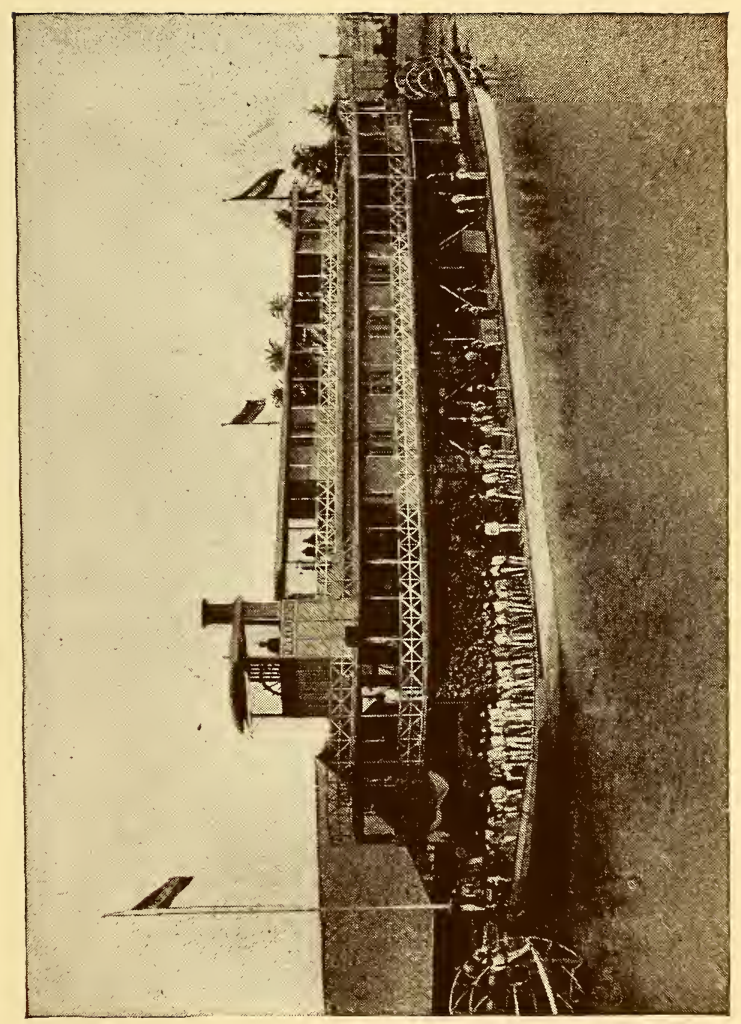





\section{A NDACROSS PANAMA}

\section{CHAPTER XXIX.}

\section{THROUGH THE WEST INDIES}

Arriving at Barranquilla, I took a steamer for the island of Curaçao, and from that time to the end of my journeys in the Caribbean regions there were no exciting adventures. I found at the Dutch West Indies a thrifty, hardworking people, a clean, well-ordered city (Williamstadt), and charming but unpretentious little villages. I found a place of cleanliness, security, and order, where the trade-winds sweep continuously over rugged cliffs, saturating all the air with the salt and moisture of the blue sea, for deep water lies close against the islands; a place in which to rest, recuperate, and watch the waves beating against the shore. I left the island with regrets, and went along the coast of Venezuela, stopping at different ports, but not remaining to make examinations, 351 


\section{AROÚND THE CARIBBEAN}

for in Venezuela security is not sufficient even in times of peace. The lands are rich, and the resources abundant, but the system of administrations permits too many unjust, even ruinous exactions, and the riches of Venezuela had best remain where they are, and Americans had better not seek after them till we have a government at Washington that will protect our citizens abroad against the first aggression, rather than wait till some great act of violence is committed, and then, when no service can come of it, make feeble protests. But the Americans abroad have no opportunity to vote, and what do the politicians at Washington care about them? Some years ago I met an American cruiser at a tropical port, and went to the captain on behalf of some fellow citizens, soliciting aid in bringing a party of Americans from a point of great danger during a revolution. We did not ask for the expenditure of any money, but wanted an American officer to take the flag and go with an expedition we were fitting out to rescue our friends. But no, the captain's instructions from Washington were to do nothing: the Americans might be in ever so great danger, but he was to do nothing; 


\section{AND ACROSS PANAMA}

if some of them were killed, he would, of course, take the matter up. In other words, until they were killed, it was of no consequence; only dead Americans were of importance at Washington; alive they must take care of themselves. We brought the Americans out safely, but they lost a lot of property. A lesson to the Americans that they had better leave the more exposed places to be occupied by their European competitors. And for this reason I passed Venezuela by, though its recources are magnificent.

Americans take great risks in the Spanish republics; in some the risk is greater than in others. If only American lives, property, and interests were vigorously protected in those treasure-lands to the south of us, it would be worth $\$ 200,000,000$ annually in trade to our country. I have seen all those lands, I know what I say. But Americans abroad do not come home to vote; what do the politicians at Washington care about them?

From the coast of Venezuela I went to the island of Trinidad, and there saw the progress and oppressive taxation common to all British Crown colonies. The government officials made good salaries and pensions, - all charged 353 


\section{AROU N D THE CARIB BEA N}

against the island's taxes; the large landowners had in abundance, but the people were desperately poor. The country is rich and productive, but there is no special opportunity for Americans in this, or any other British island. I have not found any Americans who considered themselves really welcome as residents among the people, or who felt that they had received, or would receive, entire justice in dealing with colonial officials in tropical British colonies. So it was in Barbadoes and the smaller islands; all of them places of the most charming beauty, desirable for tourists and salesmen, but none of them favourable places for permanent residences and investment on the part of Americans.

I found Porto Rico gradually emerging from its period of depression, a beautiful island rich in small opportunities, where patient industry will bring its reward, and fruit-growing seems particularly attractive.

In Hayti I found a country sinking into barbarism, a place where a foreigner takes great risks even when doing nothing. When I stopped there, a revolution was brewing, and going about was difficult. Guards were at most of the cities, and my presence gave them an oppor- 


\section{A NDACROSS PANAMA}

tunity to display their authority, and I was watched with care and caution. At Port au Prince I found the guards at one of the gates sleeping, and I slipped past them out into the country. There is no fairer land in all the world than this island of Hayti, and the country surrounding the city of Port au Prince was particularly interesting. I wandered about alone for some hours, and late in the afternoon made my way up one of the hills overlooking the harbour. Here I found a deserted stone building, the doors standing open; I thought to enter, but as a precaution gave a smart knock on the door with my walking-stick. Instantly, like a swarm of black ants, a lot of negro soldiers came crowding out of the doors; aroused from sleep, they now stood open-mouthed at the intrusion. Apparently I was in a scrape, but I stood my ground, looking at them steadily. Then I made a motion as if I wished to pass the fort. This was energetically forbidden, and I made them think I was disappointed and angry; a subterfuge which had the desired effect, because it gave them an opportunity to exercise authority and command obedience, their most dearly cherished ambition, and I was or355 


\section{AROUND THE CARIBBEAN}

dered violently to retrace my steps and go down the mountain. This I did with a show of reluctance, but inwardly glad to get away and to allow them to shout their orders out after me till I was out of sight.

From Hayti I went to Jamaica, the best and most beautiful of all the British colonies in America. I remained some time on the island, where I found many courteous people, whom I remember with the highest regard. This island has been so ably and so frequently described that little remains to be said in regard to it. The lands are fertile, and many of its regions are of unrivalled beauty; picturesque mountains, tropical glades, and charming plantations, all claim the delighted attention of travellers. The negroes do not have the highest regard for Americans, but they are entirely peaceable, and I have frequently wondered that this beautiful island, where there is every security and unquestionable order, should be so much neglected by Americans, who would there find an ideal place for a winter home. Perhaps the negroes of Kingston, the principal city, make a bad impression, and it is a fact that an ugly hackdriver is allowed to block the way of a tourist 


\section{A NDACROSS PANAMA}

so that, in crossing the street, one must go around through the mud if he does not wish to use the hack, or a strong black fellow may follow, impertinently demanding alms, while the police officers look on complacently; but this is a very small matter, and, outside the city of Kingston, Jamaica is most orderly and attractive, the negroes are good-natured and obliging, the roads perfect all over the island, and the varied scenes among the mountains and valleys a perpetual delight.

I have travelled pretty much all over the island, and am always interested in its people. I well remember one beautiful Sunday morning when I was stopping with some young engineers who were at work on one of Jamaica's famous roads. We were sitting in front of the house, when an old Baptist preacher came along. $\mathrm{He}$ was as black as one could imagine, a broad smile on his face, and a well-worn Bible under his arm. One of the young men made some joking remark as he went by. The old man turned around, all smiles and energy, took off his hat, and, with a sweeping bow, said, "Darh you are again, marstar, pokin' fun at me, and $I$ is only a-dooin' my duty a-humbly; but de las' day am 357 


\section{AROUND THE CARIB BEAN}

a-comin', de las' day am a-comin', marstar. But I don't think dat you is a-goin' to a bad judgment on dat day; by em by, you is again to be like Saul, an' do great t'ings for de Lord, marstar," and the old man's voice became pathetic as he added, " because you is able, marstar; it is all for de Lord's good time, all for de Lord's good time, marstar." The young men had nothing to say, and the black preacher went smiling to his congregation, where, in a tumble-down meeting-house, he was shortly frightening the wits out of a crowd of astounded darkies by his mighty eloquence and pictures of the condemnation that was surely coming to all of them.

In the interior parts of Jamaica life is rather rough, but one is never far from a handsome country-place or a hospitable village. I lived in the mountains of Trelawney Parish for a time, occupying a hut of two rooms, where the wind came sweeping through the gaping cracks, and when it rained the hut soon became wet inside; but then it was pleasanter than the bare ground and open woods. Once a company of big red ants found these advantages attractive; at first I did not pay any attention to them; 


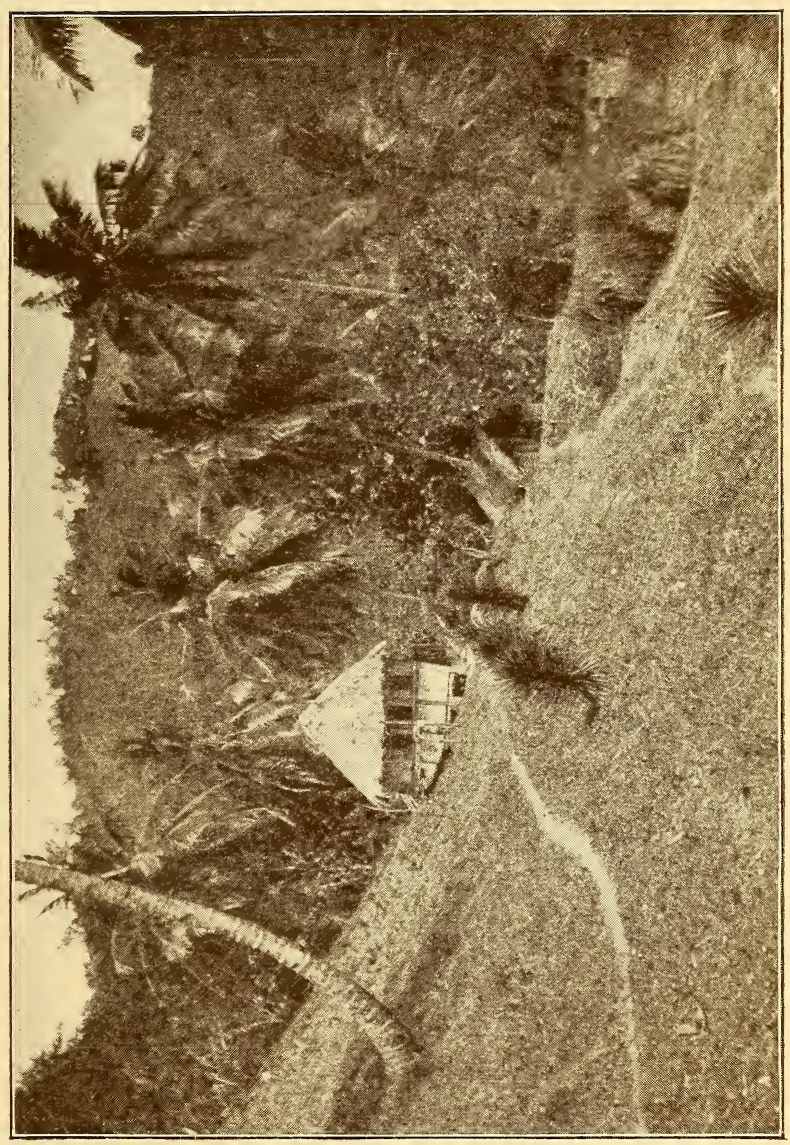





\section{A NDACROSS PANAMA}

they just wandered around in an aimless way, and apparently intended no harm; but they began to increase, and one damp morning I found, on opening a travelling-box, an enormous nest of them, hundreds and hundreds, and they immediately began to contest my rights. Some of them had big jaws, and could draw blood freely, inflicting a most painful wound. I killed them all, and thought I was well rid of them, but early next morning I found they had taken pcssession of my bed, and apparently objected strongly to my presence. I did not intrude on them more than necessary, but something began to stir up my feelings, and I was out of that bed quicker than I had considered it possible, and stood shivering in my pajamas, looking on in despair at those disgusting ants that were now chasing about over the bedclothes with open jaws, trying to catch whatever it was that had broken up their rest. Presently they went to bed again, and I sat up in the cold, watching over them and waiting for the sun to rise. Shortly the slaughter began, and of course the ants got the worst of it; but that did not stop them at all, and next night they gathered again and made directly for my bed. 359 
I tried to be brave and fight them, but they were many and I was only one, and so I retreated, gave them the bed, and took to my hammock; but they even followed me there, and next night $I$ was in doubt whether to give them the hammock and take to the bed, or give them the bed and take the hammock. The latter seemed more prudent, but before turning in I killed a few, and put the lantern on the floor. The smell of their dead seemed to enrage them, and for some reason or other they took the lantern as their common enemy, and I fell asleep to the sharp clinking of their jaws against the tin. This kept them amused, and let me have some rest, and so we had a fair arrangement for a time, but I was truly glad when, after the storm cleared up, the ants went back to the woods and meadows, leaving me to occupy my hut in security.

In Jamaica the negroes are unreasonably superstitious, and have a great fear of charms and spells, which they firmly believe can be evoked to do them harm. The following incident is a good illustration of their fears:

I was near the little town of Christiana, collecting fossils in an open lot where the limestone 


\section{A NDACROSS PANAMA}

had been weathered down, leaving the specimens exposed. I was deeply interested in my work, and gave little heed to my surroundings. Evening was coming on when I noticed a negro boy of some fifteen years sitting on the fence, watching me with wondering eyes and intense interest.

I looked at him and said, "Boy, what for you look at me so?" To which he replied, "Suh, marstar, what for you want dem 'tone t'ings?"

Knowing their superstition and dread, I replied, "For go kill a man down the mountain."

Then he looked at me with frightened eyes, saying, "Suh, marstar, for true?" and stared at me worse than ever; in fact, it seemed as if he could not move his frightened eyes from me and from the specimens I was gathering.

Then I said, severely, "Boy, what for you look at me so; think I like that? You mad me for true; pretty quick I kill you, too. You see dat 'tone t'ing," showing him a specimen of a fossil shell; " now you wait, when I find the mate to that, then I kill you, you'll see."

Then I went on gathering specimens, became interested, and thought no more of the frightened darky sitting on the fence.

361 


\section{AROUND THE CARIBBEAN}

Evening came over the hills, and in the soft tropical night that followed quickly after the sun had set I was walking slowly down to my lodgings in the village; but presently my walk was disturbed by a black boy tagging after me, now coming to my side, and then starting back as if in great fear. This continued for some time, and I stopped, saying, "Well, my boy, what's troubling you?" at which he replied, in a voice of beseeching despair, "Mister, general, colonel, squire, my lord, marstar, don't! Oh, don't! I know you can do it, but you ain't goin' for to do it," and the long string of titles was repeated in most pathetic tones.

"Don't what?" I asked, surprised. "Why, kill me with dem 'tone t'ings," he answered, wildly astonished that I did not remember.

"Well," I answered, "promise me you will never get drunk, and I will let you off this time." He promised eagerly, and then ran away in the gathering darkness.

I wonder if he kept his word and earnest promise. It would be a good thing if he did, for drunkenness is one of the evils in Jamaica.

The negroes are very susceptible through their superstitions, and I am told that one of 


\section{A NDACROSS PANAMA}

the best methods of protecting one's garden from petty thieves is to hang up a black bottle with a white feather sticking out of it.

At another time I was travelling through a district known as the Cockpit Country, a peculiar place where there are great masses of limestone rocks eroded into all sorts of shapes and almost impossible ledges. There is no water for miles, though there are numerous sink-holes where the rains have worn out deep round hollows, and the water escapes through the porous rocks. These hollows give the name to the district.

After going along the trail for some distance, my guide told me to walk carefully, because if one should slip the fall would never end, as there was a pit just by the trail that had no bottom.

Of course I insisted on seeing a place so strange, and on being taken there, started to go closer to examine it. My guide protested, saying that a wind would surely come and suck me down. This did not seem probable, but I went cautiously toward it, while the darky still protested, standing first on one foot and then on the other.

363 


\section{AROUND THE CARIBBEAN}

I found a great circular opening in the limestone cliffs, and pushed a stone over the side. It disappeared in the black depths, and fell with a hissing sound for some seconds till it crashed on the bottom; and the rocks trembled with the shock, while the darky was scared almost speechless. But after a time his fears were overcome, and he eagerly brought stones and big rocks, urging me to throw them down, saying that there were bad things in the bottom. There was a big boulder lying just behind the pit, and together we pried it over. As it fell, the rushing sound almost took my breath away, and the crash which followed shook all the rocks till I thought they would tumble down around us. I had quite enough then, and went on looking for other things; and as I went I heard my black guide saying to himself, "Well, a nigger could no more 'a' looked down dat pit without the wind took him; but de white man, dat different."

This shows the deep respect that the negro of Jamaica has for the white man, and indicates how safe one is among them, and an incivility has been rare. The island possesses every advantage, beautiful scenery, clear, cool moun- 


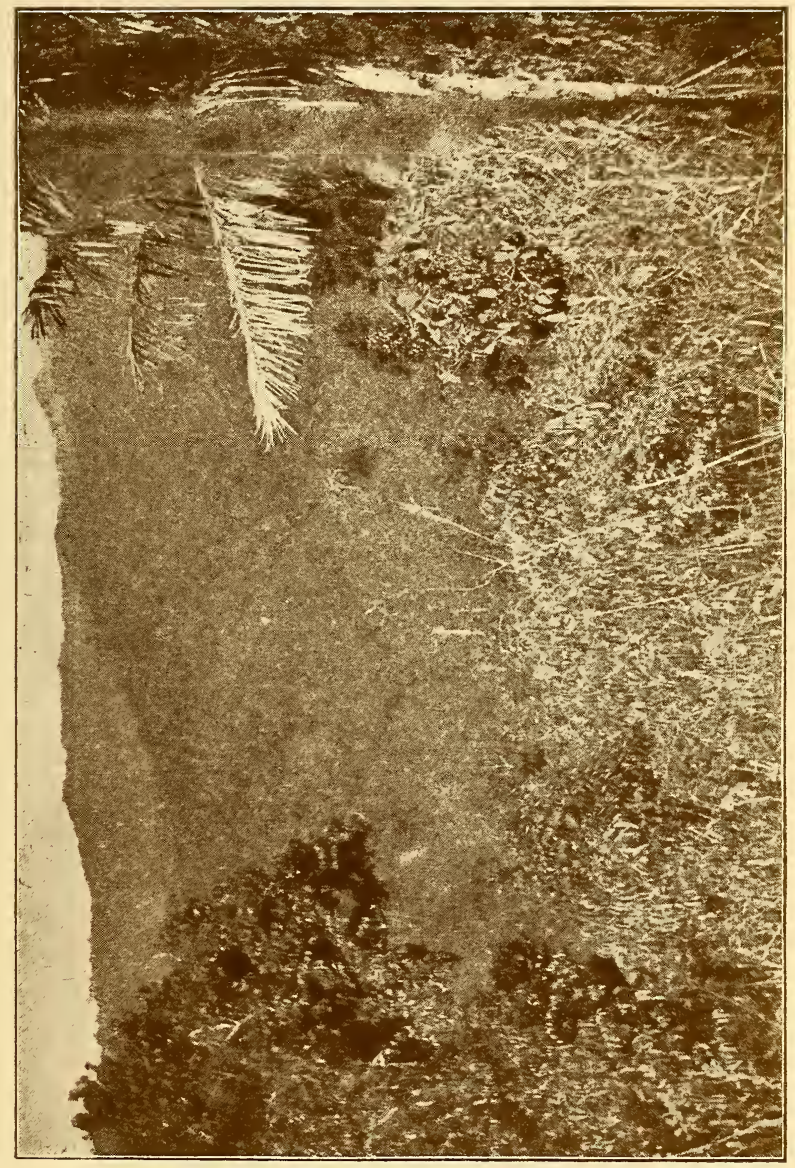





\section{A N A CROSS PANAMA}

tain air in the uplands, and the hot, dreamy tropics along the coast; there is the most superb sea-bathing at many places, and all over the island the driving roads are a delight to the tourist. There are hot sulphur springs and other medicinal waters, and the future of this tropical island, with its security and stable government, is bright indeed, and each year the winter colony is increasing.

From Jamaica I went to Cuba, a republic in which we are deeply interested, but unfortunately our interest is treated with distrust. The Cubans want to be free, as they call it. They have never known freedom, and cannot but dread any control on the part of a foreign government, and so do not realize that free America would be quite different from tyrannical Spain; but they have suffered so much from foreign control that they dread it, and want to be entirely independent, with their own government; and who can blame them, even if they are not wise, and reject their great and probably only opportunity to become a part of the mightiest republic the world has ever known.

Cuba has been thoroughly written up, agri365 


\section{AROUND THE CAR IBBEA N}

cultural resources and mining wealth; and shrewd natives who trade, not too scrupulously perhaps, and demanding more than their products are worth, often refuse to sell for fear that the purchaser might be obtaining an advantage; or who endeavour to obtain terms by alleging that offers favourable to themselves had been made, though at first they had offered any conditions themselves in order to secure a prospective customer's interest. An incident illustrating their methods may be interesting. While stopping at Havana, I was told that a Cuban general wished to talk to me in regard to mines. Certainly I was pleased to see him, and went to the place appointed for our meeting.

I found a rather untidy, ill-appearing gentleman, who told me that, while wandering about Cuba with the revolutionary army, he and some other officers had discovered a number of mines, all of which they had carefully noted, and now wished to find a mining expert who would go with them to see which of the different properties indicated were valuable, and provide the small amount required for taking out the title, for which service they offered a half interest 


\section{A ND ACROSS PANAMA}

in their discoveries. This looked like good business, and I said I would consider the matter, and agreed to meet them next day.

My next interview was with the whole combination, people strongly suggestive of brigands, and I fell to wondering what they might be after, and now made cautious answers to their questionings. However, negotiations were continued, and a paper was prepared for signature; then one of the men said, "When will you pay the hundred dollars?"

"What hundred dollars?" I asked.

"The money you promised for each mine we show you."

"Oh!" I replied, waiting to hear more.

"Certainly," he continued, "we understand that you agree to pay us one hundred dollars for our services in showing you each of the mines." The general added hastily, addressing the company, "Do not concern yourselves; we are dealing with a gentleman," bowing to me, "who will not contend over a sum so small in such an important business. The gentleman remembers what he said."

But the gentleman did not remember, and I told them plainly that, while I was ready for 367 


\section{AROUND THE CARIB BEAN}

enterprises, I would have nothing to do with any business where my associates attempted to make money out of me rather than out of the business. Then I left them; their game was too apparent, and I had seen enough of it.

This illustrates a condition which one must expect in many Cuban transactions. They all endeavour to draw one on to consider a proposition, and then seek to add conditions favourable to themselves, after they think one is sufficiently interested; sometimes even after verbal agreements had been made; but always some condition to be added which had not been spoken of at first.

Then, at exaggerations our Cuban friends are past masters. I went to examine a chromium mine in the Santa Clara Hills, which the owner said was one of the most valuable in Cuba. He showed me assays of the mineral, and orders for large shipments from well-known consumers, and was so sure that abundant ore was in sight that I agreed to go and look at his property. After some trouble and expense I reached the place, a beautiful location among rolling grassy hills, but all the mine we could find consisted of a few bits of chromic ore scattered about on the 


\section{ANDACROSS PANAMA}

surface, where there was an extensive serpentine formation, a possible but not very encouraging prospect. Yet the owner had described ledges of pure chromium ore, and splendid facilities for extraction. He had made contracts for delivering to the steamers when he should receive orders, and he was sending all over Europe and America soliciting purchasers for cargo lots, and all because he had found a little float ore on the surface.

These are illustrations of Cuban business methods. Opportunities are not lacking in that beautiful island, but its people are overgreedy, imaginative in the extreme, so Americans must be cautious.

I was disappointed in the chromium mines, but I was delighted with the Santa Clara Hills. In Havana I had been told to beware of brigands and dangerous men, but $I$ found only a kindly disposed peasantry such as I have met at all country places throughout Spanish America.

I travelled over the greater portion of Cuba, and found a rich, attractive island, the resources mostly agricultural. The lands are flat for the greater part. Only in the eastern portions of 369 


\section{AROUND THE CARIBBEAN}

the island are there mountains of any considerable elevation. Much of the island is surrounded by swamps and lagoons, succeeded by broad, rich plains and then the low hills of portions of the interior.

When my examination in Cuba had been finished, I returned to New York, having travelled over all the regions surrounding the Caribbean Sea. 


\section{AND ACROSS PANAMA}

\section{CHAPTER XXX.}

\section{A FAITHFUL GUIDE}

I HAve alluded several times to a kindly disposed peasantry found all through Spanish America. Frequently, in and near the cities, dangerous characters are met; out in the country, where rum is scarce, especially in the more elevated regions, sobriety, intelligence, and industry rule; and if it were not for the frequent revolutions, originating in the cities, the Spanish Americans of the uplands and the country places would soon make prosperous regions of their beautiful republics.

An incident in closing will illustrate their faithfulness.

For some time I have been directing the development of properties belonging to the South American Land and Exploration Co., Ltd., in Colombia. I have always thought it best to urge 371 


\section{AROUND THE CARIBBEAN}

any work that I might have on hand, and have secured a rather peculiar reputation among my men, who speak of me as the person who never rests. A touching incident occurred because of this urgent haste in my undertakings while I was away from the property. One of my best men lay dying. A burning fever was on him, contracted because of over exposure in one of the heavy rains of that country. He was delirious, and fancied that I was coming and would be wanting him to start at once for some expedition. In vain the Priest bending over him said, "Manuel, you will never go to the woods with Doctor Nicholas again. Think of other things now; you are dying."

"No, no," he replied, " get the mules ready, get the canoe. Doctor Nicholas is coming. We will be going to-day; he will never wait."

The priest expostulated, gently trying to draw his attention to the life beyond, but Manuel would not hear him, and, rising up suddenly in his bed, cried, "I told you Doctor Nicholas was coming; there he is now." Then my faithful guide and companion fell back dead.

Manuel had been a leader among the rough men of the north coast of Colombia, and the 


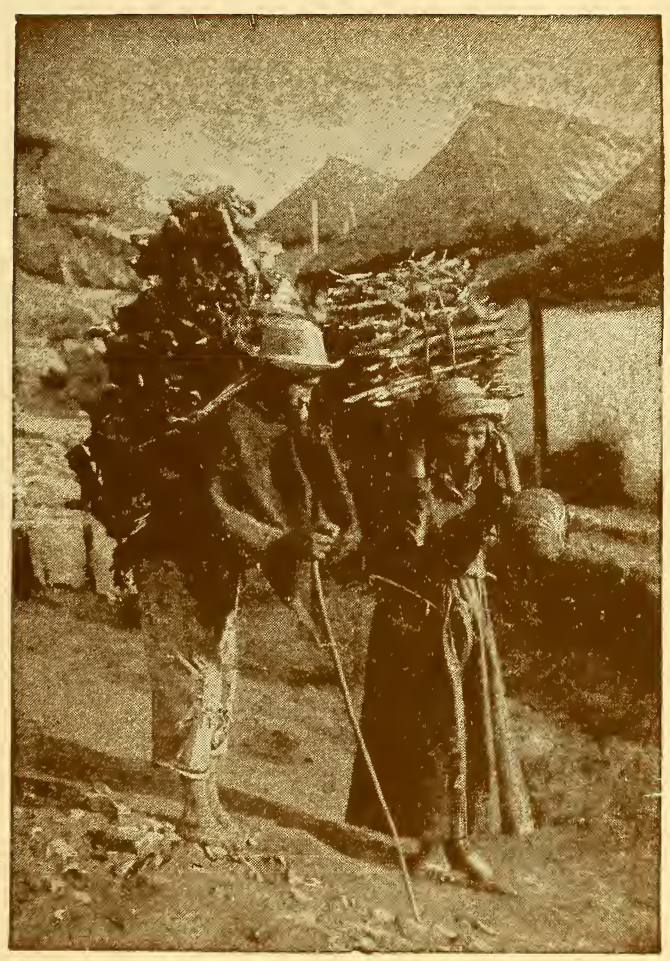





\section{A N D ACROSS PANAMA}

next time I visited Dibulla, a little town near the company's property, the story was told to me just as I have written it here, but it was more impressive. I was surrounded by his sorrowing friends, sorrowing with them for our loss.

As I write now, I wonder if it has fallen to the lot of many men to have contended with difficulties such as I have met, and to have been served through them all as I have been served. 





